\title{
Políticas de escalonamento memory-intensive para aplicações distribuídas
}

\author{
Luís Cézar Darienzo Alves \\ Orientador: Prof. Dr. Marcos José Santana
}

Dissertação apresentada ao Instituto de Ciências Matemáticas e de Computação - ICMC, USP, como parte dos requisitos para obtenção do título de Mestre em Ciências - Ciências de Computação e Matemática Computacional.

\author{
USP - São Carlos
} maio/2008 

À minha querida esposa Wilnice que tem sido uma fonte inesgotável de paciência e compreensão, sendo meu porto seguro nas horas mais difíceis, ensinando-me a viver e a admirar a vida pelo seu lado mais doce. 



\section{Agradecimentos}

Agradeço primeiramente a Deus, por me apresentar oportunidades e me orientar nas decisões.

À Wilnice, minha esposa, pela paciência e compreensão ao dividir comigo suas opiniões sobre o meu trabalho, sempre de maneira sábia e serena. Sem ela este trabalho não teria sido desenvolvido.

Ao Prof. Dr. Marcos Santana, pela orientação e confiança durante o desenvolvimento deste trabalho. Servindo para mim como modelo de mestre e de ser humano, uma referência a ser seguida.

À Prof. Dra. Regina, pelas contribuições sugeridas, sendo de fundamental importância para as decisões tomadas neste trabalho. Além da amizade e dos ensinamentos transmitidos.

Aos meus pais, Joaquim e Vani, pela educação, por estarem presentes nos momentos importantes da minha vida, pelo apoio e carinho.

Ao casal Wilson e Larenice, que sempre me receberam com atenção e carinho.

Aos demais professores do LaSDPC, que de maneira direta ou indireta, contribuíram para este trabalho.

Aos meus colegas e amigos da USP e do LaSDPC, cujos nomes omitirei para não cometer a injustiça de esquecer algum, que através das reuniões do grupo ou até mesmo em conversas informais, teceram comentários importantes para o desenvolvimento deste trabalho

Aos funcionários do ICMC-USP, pelo convívio amigo e descontraído. Em especial Laura e Ana Paula que sempre me atenderam de maneira exemplar.

À FAPESP pelo apoio financeiro dado a este trabalho. 

"Nenhum homem realmente produtivo pensa como se estivesse escrevendo uma dissertação.' 



\section{Resumo}

ALVES, L. C. D. Políticas de escalonamento memory-intensive para aplicações distribuídas. Dissertação (Mestrado) - ICMC, USP, São Carlos, 2008

Esta dissertação aborda o escalonamento de processos em sistemas de clusters de computadores, tanto em plataformas homogêneas quanto heterogêneas. As heterogeneidades abordadas incluem a potência computacional dos processadores, quantidade de memória principal do sistema e o tempo médio de acesso ao disco. Neste trabalho são propostas quatro novas políticas destinadas a realizar o compartilhamento de carga nesses ambientes, considerando cargas de trabalho com aplicações variando entre CPU-bound e memoryintensive. Dentre as quatro políticas, uma utiliza apenas índices de $C P U$, enquanto as demais utilizam também índices de memória. Os resultados foram obtidos através de simulações baseadas em trace e mostram reduções significativas das perdas de desempenho observadas nos resultados obtidos com as políticas de escalonamento propostas. Como referências foram utilizadas políticas de escalonamento tradicionais encontradas na literatura.

Palavras-chave: Avaliação de desempenho, escalonamento de processos, clusters de computadores, sistema de imagem única, aplicações memory-intensive e simulação. 



\section{Abstract}

ALVES, L. C. D. Memory-intensive scheduling policies for distributed applications. Thesis (Master) - ICMC, USP, São Carlos, 2008

This dissertation approaches the process scheduling on clusters of computers, on both homogeneous and heterogeneous platforms. The heterogeneities considered include processor computational power, system main memory quantity and the average disk access time. In this work are proposed four novel policies aimed at realizing the work load sharing on these environments, considering workloads with applications varying between CPU-bound and memory-intensive. Among the four policies, one of them uses only CPU indices, while the others also use memory indices. The results were obtained by means of trace-based simulations and show a significant reduction on the performance losses observed on the results obtained with the proposed scheduling policies. As references were used traditional scheduling policies found in the literature.

Keywords: Performance evaluation, processes scheduling, computer clusters, singlesystem image, memory-intensive applications and simulation. 



\section{Lista de Figuras}

2.1 Características dos clusters computacionais [1]. . . . . . . . . . . . . . 6

2.2 Estrutura PVM. . . . . . . . . . . . . . . . . . . 9

2.3 Middleware de imagem única. . . . . . . . . . . . . . . . . 10

3.1 Componentes envolvidos no escalonamento [16] . . . . . . . . . . . . . . . 13

3.2 Composição dos escalonadores [8] . . . . . . . . . . . . . . . . . . . . . . . 14

3.3 Taxonomia proposta em [16], apresentando uma classificação hierárquica. . 18

4.1 Classificação das Aplicações [8]. . . . . . . . . . . . . . . . . . . 27

4.2 Tamanho ótimo da partição ao analisar, ou não, a ocupação da memória [21]. 31

4.3 Tempo de resposta das aplicações utilizando diferentes tamanhos de partição $[21] \ldots \ldots \ldots$. . . . . . . . . . . . . . . . . . . . . . . . . . . . . . . . . . . . . . . . 32

4.4 Arquivo $/$ proc/stat. . . . . . . . . . . . . . . . 36

4.5 Arquivo $/$ proc/meminfo. . . . . . . . . . . . . . . 36

4.6 Arquivo $/$ proc/mvstat. . . . . . . . . . . . . . . 37

4.7 Comportamento do índice $2[5] \ldots \ldots \ldots$. . . . . . . . . . . 38

4.8 Comportamento do índice $3[5] \ldots \ldots$. . . . . . . . . . . . . . . . . . 39

4.9 Comparativo métrica 1 versus índice $2[5] \ldots \ldots$. . . . . . . . . . . . . 40

4.10 Comparativo métrica 1 versus métrica $2[5] . \ldots . . . . . . .41$

4.11 Comportamento da métrica $3[5] \ldots \ldots$. . . . . . . . . . . 42

4.12 Comportamento dos índices 8 e $9[5] \ldots \ldots$. . . . . . . . . . 43 
4.13 Comportamento dos índices 10 e $11[5] \ldots \ldots$. . . . . . . . . . . 45

4.14 Comportamento da métrica $4[5] \ldots \ldots$. . . . . . . . . . . . . 46

4.15 Comportamento do índice $1[5] \ldots$. . . . . . . . . . . . . . 47

4.16 Comportamento da métrica $5[5] \ldots \ldots \ldots$. . . . . . . . . . 48

5.1 Modelo do sistema. . . . . . . . . . . . . . . . . . . 51

5.2 Arquivo de trace. . . . . . . . . . . . . . . . . . . . 53

5.3 Diagrama de casos de uso. . . . . . . . . . . . . . . . . . 55

5.4 Arquivo de configuração. . . . . . . . . . . . . . . . . . . . 56

5.5 Modelo de sistema com escalonamento centralizado. . . . . . . . . . . . . 60

5.6 Segunda parte do arquivo de relatório. . . . . . . . . . . . . . . . . 61

5.7 Diagrama de classes. . . . . . . . . . . . . . . . . . . . 64

5.8 Diagrama de atividades: Geral. . . . . . . . . . . . . . . 65

5.9 Diagrama de atividades: Ajustar tempo da simulação. . . . . . . . . . . . . 66

5.10 Diagrama de atividades: Verificar chegada de transferência. . . . . . . . . . 67

5.11 Diagrama de atividades: Verificar fila de swap. . . . . . . . . . . . 68

5.12 Diagrama de sequência: Verificar chegada de processos no sistema. . . . . . 69

5.13 Diagrama de atividades: Executar quantum. . . . . . . . . . . . 71

5.14 Diagrama de sequência: Executar remoto. . . . . . . . . . . . . . . . . 72

5.15 Diagrama de sequência: Executar migração. . . . . . . . . . . . . . . . . 73

6.1 Distribuição da quantidade de memória, com variação entre 64 MB e 256 MB. . . . . . . . . . . . . . . . . . . . 77

6.2 Espalhamento das quantidades de memórias geradas para o intervalo entre $64 \mathrm{MB}$ e $256 \mathrm{MB}$, com $\alpha=5, \alpha=1$ e $\alpha=0,2$, respectivamente. . . . . . . 78

6.3 Distribuição da quantidade de memória solicita pelas aplicações, com limites inferior e superior definidos em 128 MB e 256 MB, respectivamente. . . 79

6.4 Espalhamento das quantidades de memórias geradas para o intervalo entre $128 \mathrm{MB}$ e $256 \mathrm{MB}$, com $\alpha=5$ e $\alpha=0,2$, respectivamente. . . . . . . . . . 80

6.5 Topologia lógica do cluster simulado. . . . . . . . . . . . . . . . . 81 
6.6 Perdas de Desempenho sofridas pelos processos na "Plataforma 1", utilizando políticas baseadas em CPU. . . . . . . . . . . . . . . . . . 87

6.7 Ausências de páginas sofridas pelos processos na "Plataforma 1", utilizando as políticas baseadas em CPU. . . . . . . . . . . . . . . . . 89

6.8 Execuções remotas executadas pelos nós da "Plataforma 1", utilizando as políticas baseadas em CPU. . . . . . . . . . . . . . . . . . . . 90

6.9 Perdas de desempenho sofridas pelos processos na "Plataforma 1", utilizando as políticas baseadas em memória. . . . . . . . . . . . . . . . . . . 92

6.10 Ausência de páginas sofridas pelos processos na "Plataforma 1", utilizando as políticas baseadas em memória. . . . . . . . . . . . . . . . . . . . . 93

6.11 Execuções remotas executadas na "Plataforma 1" pelas políticas baseadas em memória.

6.12 Tempo médio gasto na fila de prontos, pelos processos, na "Plataforma 1", utilizando as políticas baseadas em memória. . . . . . . . . . . . . . . . . . 94

6.13 Quantidade de execuções remotas realizadas pelas políticas "CPU carga média" e "Pág. inativa carga média" nas plataformas analisadas. . . . . . . . 96

6.14 Reduções na quantidade de execuções remotas realizadas pelas políticas "CPU carga média" e "CPU carga média com DP". . . . . . . . . . . . . . 97

6.15 Perdas de desempenho sofridas pelas aplicações, na "Plataforma 1", utilizando as políticas baseadas em índices de CPU. . . . . . . . . . . . . . . . 101

6.16 Ausências de páginas sofridas pelos processos, na "Plataforma 1", utilizando as políticas baseadas em índices de CPU. . . . . . . . . . . . . . . . . 103

6.17 Perda de desempenho, na "Plataforma 1", utilizando as políticas baseadas em índices de memória. . . . . . . . . . . . . . . . . . . . . . . . . . . . . . 104

6.18 Ausências de páginas ocorridas na "Plataforma 1", ao utilizar as políticas baseadas em índices de memória.

6.19 Execuções remotas executadas na "Plataforma 1", ao utilizar as políticas baseadas em índices de memória.

6.20 Perdas de desempenho sofridas pelas aplicações na "Plataforma 2", ao utilizar as políticas baseadas, unicamente, na fila de prontos. . . . . . . . . . 108

6.21 Ausência de páginas sofridas pelas aplicações na "Plataforma 2". . . . . . . 109 
6.22 Comparação entre as perdas de desempenho obtidas, na "Plataforma 2", pelas política "CPU carga média com DP" e a política "Pág. inativa carga média". . . . . . . . . . . . . . . . . . . . . . . . 110

6.23 Perdas de desempenho sofridas pelos processos, na "Plataforma 2", ao serem escalonados pelas políticas que utilizam informações de memória. .... . 111

6.24 Execuções remotas realizadas na "Plataforma 2", ao usar as políticas baseadas em índices de memória. . . . . . . . . . . . . . . . . . . . . . . . . . . 112

6.25 Tempo médio gasto na fila de prontos pelos processos na "Plataforma 3". . 115

6.26 Perdas de desempenho sofridas pelos processos na "Plataforma 3". . . . . . 115

6.27 Execuções remotas realizadas pelas políticas baseadas em CPU na "Plataforma $3 " \ldots \ldots \ldots \ldots \ldots \ldots$

6.28 Ausências de páginas sofridas pelos processos ao serem utilizadas as políticas baseadas em índices de CPU na "Plataforma 3". . . . . . . . . . . . . . 117

6.29 Ausências de páginas sofridas pelos processos ao serem utilizadas as políticas baseadas em CPU e memória na "Plataforma 3". . . . . . . . . . . . . . 119

6.30 Execuções remotas realizadas pelas políticas baseadas em CPU e memória na "Plataforma 3".

6.31 Perdas de desempenho sofridas pelos processos na "Plataforma 4", sob o escalonamento das políticas baseadas unicamente em CPU. . . . . . . . . . 121

6.32 Execuções remotas realizadas pelas políticas baseadas unicamente em índices de CPU, ao serem executadas na "Plataforma 4".

6.33 Perdas de desempenho registradas na "Plataforma 4", ao utilizar as políticas que utilizam índices de memória. . . . . . . . . . . . . . . . . . . . . . . . 124

6.34 Ausências de páginas, ocorridas na "Plataforma 4", ao utilizar as políticas baseadas em índices de memória.

6.35 Razão entre as perdas de desempenho geradas na "Plataforma 4" e aquelas com a plataforma homogênea utilizando $F P=20 \mathrm{~ms}$. . . . . . . . . . . . . 126 


\section{Lista de Tabelas}

3.1 Formas de particionamento variável $[7] \ldots \ldots$. . . . . . . . . . 21

4.1 Váriações de carga usadas no monitoramento [5] . . . . . . . . . . . . . 37

4.2 Resumo dos índices definidos em $[5] \ldots \ldots$. . . . . . . . . . . . . . 49

6.1 Caracterização das cargas utilizadas nas simulações. . . . . . . . . . . . . 80

6.2 Velocidades dos processadores da "Plataforma 2". . . . . . . . . . . . . . 82

6.3 Quantidade de memória DRAM atribuída aos nós da "Plataforma 3". . . . 83

6.4 Tempo necessário para realizar o tratamento de uma ausência de página na "Plataforma 4". . . . . . . . . . . . . . . . . . . . . 83

6.5 Médias e intervalos de confiança da perda de desempenho na "Plataforma 1", utilizando as políticas baseadas em CPU. . . . . . . . . . . . . . 88

6.6 Médias e intervalos de confiança da perda de desempenho na "Plataforma 1", utilizando as políticas baseadas em memória. . . . . . . . . . . . . . . . 92

6.7 Médias e intervalos de confiança da perda de desempenho na "Plataforma 1".102

6.8 Médias e intervalos de confiança da perda de desempenho na "Plataforma 2".106

6.9 Médias e intervalos de confiança da perda de desempenho na "Plataforma 3".114

6.10 Médias e intervalos de confiança da perda de desempenho na "Plataforma 4".122 



\section{Lista de Símbolos}

$\begin{array}{ll}\text { bps } & \text { bits por segundo } \\ \text { CISC } & \text { Complex Instruction Set Computer } \\ \text { Clumps } & \text { Cluster of SMPs } \\ \text { COWs } & \text { Cluster of Workstations } \\ \text { DRAM } & \text { Dynamic Random Access Memory } \\ \text { MIMD } & \text { Multiple Instruction Multiple Data } \\ \text { MPI } & \text { Message Passing Interface } \\ \text { NOWs } & \text { Network of Workstations } \\ \text { PVM } & \text { Parallel Virtual Machine } \\ \text { RISC } & \text { Reduced Instruction Set Complex } \\ \text { SMP } & \text { Symmetric Multiprocessing } \\ \text { SNPF } & \text { Smallest Number of Process First } \\ \text { SPMD } & \text { Single Program Multiple Data } \\ \text { MIPS } & \text { Million Instructions Per Second } \\ \text { NFS } & \text { Network File System } \\ \text { UML } & \text { Unified Modeling Language }\end{array}$



1 Introdução 1

1.1 Contextualização . . . . . . . . . . . . . . . . . . . . . . . 1

1.2 Motivação e objetivos . . . . . . . . . . . . . . . . 2

1.3 Terminologia utilizada . . . . . . . . . . . . . . . . 3

1.4 Organização dos capítulos . . . . . . . . . . . . . . . . 4

2 Plataformas distribuídas 5

2.1 Considerações Iniciais . . . . . . . . . . . . . . . . . 5

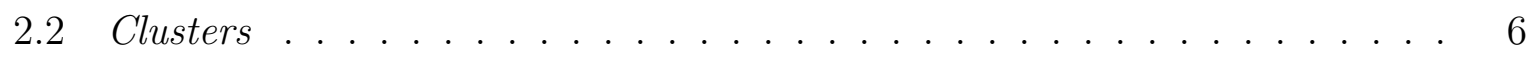

2.2 .1 Utilização dos nós . . . . . . . . . . . . . . . . 7

2.2 .2 Tipo dos nós f . . . . . . . . . . . . . . . . . . . 7

2.2 .3 Topologia . . . . . . . . . . . . . . . . . . 7

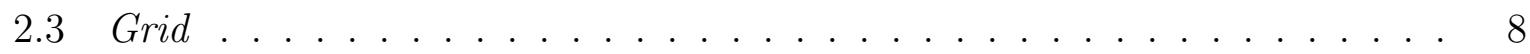

2.4 Ambientes de software ........................ 8

2.4.1 Ambientes de programação . . . . . . . . . . . . . 8

2.4.2 Middlewares...................... 9

2.5 Considerações finais . . . . . . . . . . . . . . . . . . . . . . . 10

3 Escalonamento $\quad 12$

3.1 Considerações iniciais . . . . . . . . . . . . . . . . . . . . . 12

3.2 Composição do escalonador . . . . . . . . . . . . . . . . . . . . . . . . . . 13 


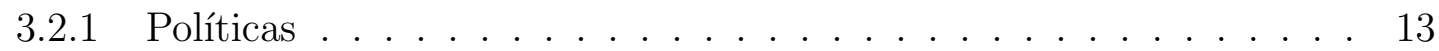

3.2.2 Mecanismos .......................... 15

3.3 Classificação dos escalonadores . . . . . . . . . . . . . . . . . 16

3.3.1 Escalonamento paralelo versus distribuído . . . . . . . . . . . . 16

3.3.2 Taxonomia de Casavant e Kuhl (1988) . . . . . . . . . . . . . . 17

3.3.2.1 Classificação hierárquica . . . . . . . . . . . . . . 17

3.3.2.2 Classificação plana . . . . . . . . . . . . . . . . . . 20

3.3.3 Taxonomia de Feitelson e Rudolph(1995) . . . . . . . . . . . . . . . 21

3.4 Balanceamento de carga em sistemas distribuídos . . . . . . . . . . . . 22

3.5 Considerações finais . . . . . . . . . . . . . . . . . . . . . . 23

4 Índices de carga $\quad 25$

4.1 Considerações Iniciais . . . . . . . . . . . . . . . . . . . . . . 25

4.2 Classes de aplicações . . . . . . . . . . . . . . . . . . . . . 27

4.3 Uso de informações no escalonamento . . . . . . . . . . . . . . . . . . . . 28

4.4 Escalonamento de aplicações memory-intensive . . . . . . . . . . . . . . . 29

4.5 Índices de carga baseados em memória . . . . . . . . . . . . . . . . 35

4.5.1 Pseudo-sistema de arquivos $/$ proc . . . . . . . . . . . . 35

4.5.2 Metodologia ....................... 37

4.5 .3 Utilização da memória . . . . . . . . . . . . . . . . . . . . . . 38

4.5.4 Atividade da memória virtual . . . . . . . . . . . . . . . . . . 43

4.5.5 Ausências de páginas . . . . . . . . . . . . . . . . . . . . 44

4.5.6 Utilização do espaço de swap . . . . . . . . . . . . . . . . . 45

4.5.7 Atividade do processador . . . . . . . . . . . . . . 46

4.6 Considerações finais . . . . . . . . . . . . . . . . . . . . . . . . . . 48

5 Modelos $\quad 50$

5.1 Considerações iniciais . . . . . . . . . . . . . . . . . . . 50

5.2 Modelagem do sistema . . . . . . . . . . . . . . . . 51 
5.3 Modelagem do simulador . . . . . . . . . . . . . . . . . . 54

5.3.1 Visão de casos de uso . . . . . . . . . . . . . . . . . . . . 54

5.3 .2 Visão estrutural . . . . . . . . . . . . . . . . . . 63

5.3.3 Visão comportamental . . . . . . . . . . . . . . 65

5.4 Considerações finais . . . . . . . . . . . . . . . . . . . . . . . . 74

$\begin{array}{llr}6 & \text { Políticas } & 75\end{array}$

6.1 Considerações iniciais . . . . . . . . . . . . . . . . . . . 75

6.2 Cargas de trabalho . . . . . . . . . . . . . . . . 76

6.3 Plataformas utilizadas . . . . . . . . . . . . . . . . . . . 81

6.4 Políticas de referência . . . . . . . . . . . . . . . . . . . 84

6.4.1 Políticas baseadas em $C P U \ldots \ldots$. . . . . . . . . . 84

6.4.2 Políticas baseadas em memória . . . . . . . . . . . . . . 90

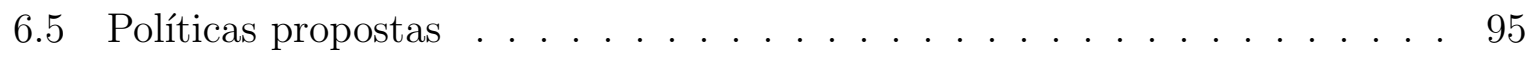

6.5.1 Baseada em CPU . . . . . . . . . . . . . . . . . 95

6.5.2 Baseada no algoritmo Assign-u . . . . . . . . . . . . . . . 97

6.5.3 Baseadas em grupos . . . . . . . . . . . . . . . . . 98

6.6 Avaliação das políticas propostas . . . . . . . . . . . . . . . . 100

6.6.1 Plataforma homogênea . . . . . . . . . . . . . . . . . 100

6.6.2 Heterogeneidade de CPU . . . . . . . . . . . . . . . . . . . . . 104

6.6.3 Heterogeneidade de memória . . . . . . . . . . . . . . . . . . 113

6.6.4 Heterogeneidade de disco . . . . . . . . . . . . . . . . 121

6.7 Considerações finais . . . . . . . . . . . . . . . . . . . . 127

7 Conclusões $\quad 129$

7.1 Considerações finais . . . . . . . . . . . . . . . . . . . . . . 129

7.2 Contribuições . . . . . . . . . . . . . . . . . . . 131

7.3 Sugestões para trabalhos futuros . . . . . . . . . . . . . . . . 132

$\begin{array}{ll}\text { Referências bibliográficas } & 134\end{array}$ 



\section{Capítulo}

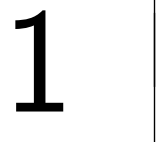

\section{Introdução}

\subsection{Contextualização}

Com o avanço da computação, se torna evidente a exigência crescente das aplicações por capacidade de processamento. Por outro lado, a indústria de processadores está encontrando barreiras impostas pelas leis da física, principalmente a velocidade da luz e algumas leis da termodinâmica. Entre as principais restrições merecem destaque o limite máximo de componentes inseridos em uma pastilha de processador, bem como o calor dissipado por ele quando executado a altas frequências. Esses limites, juntamente com os altos custos para elevar a frequência dos processadores, impossibilitam, ou pelo menos retardam o avanço das tecnologias monoprocessadas.

Nesse contexto dá-se origem à computação paralela distribuída, que permite unir elementos de processamento, tratando-os como um sistema único. A partir desse ponto é possível ampliar os recursos computacionais disponíveis para as aplicações. Uma forma de realizar essa união é através dos multiprocessadores, que consistem na união de vários processadores compartilhando uma única memória, ou um conjunto delas. Esse tipo de arquitetura é dita fortemente acoplada. Outra maneira é através dos multicomputadores, que são constituídos de vários processadores, cada um com sua memória local, denominados fracamente acoplados. [1]

Com a redução dos custos dos computadores pessoais e o grande parque de máquinas instaladas em todo o mundo, tornaram-se populares ambientes como as Network of Workstations (NOWs), que são sistemas formados por estações de trabalho ou computadores pessoais, conectados por uma rede de comunicação e disponíveis para executar 
aplicações paralelas [2]. Esses ambientes fornecem às aplicações uma melhora significativa na potência computacional, no entanto, com seu advento alguns novos problemas surgiram, pois trata-se de um ambiente que pode apresentar heterogeneidade e possuir usuários interativos, diferente das plataformas maciçamente paralalelas, como os multiprocessadores. Esses problemas estão relacionados principalmente com o gerenciamento de recursos da plataforma [3].

\subsection{Motivação e objetivos}

O escalonamento de processos é um dos problemas relacionados com o gerenciamento da plataforma. Esse assunto vem sendo muito estudado nos últimos anos, havendo na literatura vários trabalhos que referenciam políticas de escalonamento baseadas na utilização do processador. Entretanto, há uma lacuna a ser preenchida com relação às aplicações caracterizadas pela utilização de memória, uma vez que, nos equipamentos modernos, a $C P U$ apresenta uma velocidade muito maior que as memórias, tornando-se estas um gargalo no sistema.

Atualmente, com a utilização de memória virtual, discos rígidos também têm sido utilizados como memória temporária, devido ao baixo custo e grande capacidade de armazenamento quando comparados às memórias do tipo Dynamic Random Access $\mathrm{Me}$ mory (DRAM) [4]. O disco rígido é utilizado principalmente para tratar ausências de páginas, onde duas situações são possíveis. Na primeira ocorre uma ausência de página e encontram-se molduras ${ }^{1}$ disponíveis na memória principal para que esta seja carregada, não utilizando a memória secundária; ao contrário, na segunda não existem tais molduras disponíveis, obrigando o envio de alguma página para o disco, swap out, para que outra possa ser trazida para a memória principal, swap in [4].

A última situação é indesejável para um sistema, pois pode levá-lo ao estado de trashing, fazendo com que o sistema operacional permaneça grande parte do tempo tratando ausências de páginas e realizando pouca computação útil no contexto do trabalho a ser processado [5]. Tal situação pode ser evitada trabalhando com escalonamento baseado na utilização de memória e não somente do processador, que pode estar com pouca atividade instantes antes do trashing [6].

Nesse contexto, encontra-se o trabalho de mestrado desenvolvido em [5], que descreveu onze índices de cargas baseados em utilização de memória, juntamente com cinco métri$\operatorname{cas}^{2}$. Tais índices são obtidos através do pseudo sistema de arquivos /proc do sistema

\footnotetext{
${ }^{1}$ Uma moldura é uma estrutura de dados utilizada pelo sistema operacional para abrigar uma página.

${ }^{2}$ Combinações entre os índices.
} 
operacional $G N U /$ Linux $^{3}$, gerando assim uma oportunidade ímpar para explorar esses índices, na forma de políticas, em um sistema operacional que é um dos mais utilizados na criação de clusters. Dessa forma, desenvolveu-se políticas de escalonamento, focando aplicações distribuídas memory-intensive, comparando os resultados obtidos com outras tradicionais baseadas na utilização do processador.

\subsection{Terminologia utilizada}

Na computação paralela distribuída alguns termos são utilizados de diferentes maneiras pelos mais diversos autores, fazendo-se necessário definir, no contexto deste trabalho, alguns termos que serão utilizados no decorrer desta dissertação.

Processos: Os processos são programas em execução, compostos pelo código executável, dados, pilha, contador de programa e demais informações necessárias para a sua correta execução [4].

Os processos são autônomos e executam em seu domínio de proteção, não sendo permitido a nenhum processo acessar o espaço de memória reservado a outro, nem mesmo interferir nas trocas de mensagens [7].

Threads: São também denominadas processos leves (lightweight processes). Um processo pode ser formado por uma ou mais threads, que são linhas de execuções, concorrentes, que executam compartilhando o ambiente do processo.

Ao serem escalonadas para execução as threads executam de maneira seqüencial como um processo. Assim, um processo pode possuir apenas uma thread em execução, em um dado instante de tempo em cada núcleo de processamento. Seu escalonamento pode ser realizado pelo núcleo do sistema operacional (threads de núcleo), ou pela própria aplicação no espaço do usuário (thread de usuário) [4].

Tarefa e aplicação: Os termos tarefa e aplicação são sinônimos e representam o conjunto de processos de um software seqüencial ou concorrente, constituindo a visão do usuário durante a execução. Assim, o tempo de resposta para o usuário é o tempo gasto por todos os processos que constituem a aplicação submetida por ele no sistema.

\footnotetext{
${ }^{3}$ Tratado deste ponto em diante por Linux.
} 


\subsection{Organização dos capítulos}

O capítulo 2 apresenta os conceitos relacionados às plataformas distribuídas, esclarecendo conceitos como computação distribuída, paralela e paralela distribuída, caracterizando os clusters e grids computacionais, bem como o ambiente de software necessário para criar a camada de abstração para o usuário da plataforma.

O capítulo 3 apresenta os conceitos relacionados à atividade de escalonar processos, descrevendo a composição e as classificações dos escalonadores. Apresenta também o conceito de balanceamento de carga abordado neste trabalho.

No capítulo 4 são caracterizados os índices de carga, destacando-se as classificações das aplicações, principalmente as denominadas memory-intensive, que são alvo desta pesquisa. A principal seção desse capítulo destaca os índices de carga baseados em memória, propostos em [5], apresentando seus pontos fortes e fracos, uma vez que serão utilizados nas políticas propostas nesta pesquisa.

No capítulo 5 serão discutidas as técnicas de avaliação de desempenho, destacando-se a técnica de modelagem, que foi adotada neste trabalho. Será abordada também a resolução de modelos por simulação onde um modelo de sistema de imagem única, baseado em redes de filas, a ser simulado, será proposto. Este capítulo apresentará ainda a modelagem, em Unified Modeling Language (UML), do software de simulação adotado.

No capítulo 6 serão apresentadas as novas políticas propostas neste projeto, comparando-as, através dos resultados das simulações, com outras políticas já existentes na literatura. Para avaliar estas políticas a carga de trabalho será caracterizada através da distribuição de Pareto, definindo cinco cenários com tipos de carga diferentes.

Finalmente, no capítulo 7 serão apresentadas as conclusões obtidas durante este projeto, destacando-se as contribuições alcançadas, bem como propostas de trabalhos a serem desenvolvidos futuramente. 


\section{Capítulo \\ 2 \\ Plataformas distribuídas}

\subsection{Considerações Iniciais}

Cada vez mais, a busca por desempenho se faz presente nas mais diversas áreas em que a computação está envolvida. Fatores como a melhora dos algoritmos e o tamanho do conjunto de dados, exigem recursos computacionais cada vez maiores. Assim, a busca pelo menor tempo de execução de uma tarefa, constituindo uma melhora de desempenho, impulsiona o desenvolvimento da computação paralela distribuída [8].

Vários termos atualmente se fazem presentes nesse contexto, merecendo destaque a diferenciação entre computação paralela, distribuída e paralela distribuída:

Computação Paralela: Nesse ambiente uma aplicação é dividida em partes e executada em vários processadores, existindo uma dependência entre as partes que estão sendo executadas, devendo ser novamente unidas ao final para expressar um ou mais resultados. Espera-se uma redução no tempo de resposta da aplicação, se comparado ao gasto em uma arquitetura monoprocessada. Nesse ambiente várias aplicações podem ser executadas, porém a característica da divisão do todo em partes permanece existindo[1];

Computação Distribuída: Essa categoria surgiu devido à necessidade de compartilhamento de recursos, dessa forma é criado um sistema único, através de middlewares ${ }^{1}$,

\footnotetext{
${ }^{1}$ Pacotes de softwares executados sobre um conjunto de computadores, que fornecem certas estruturas de dados e operações, permitindo que usuários em computadores distintos se relacionem de maneira consistente [4].
} 
em que as aplicações são executadas independentes uma das outras, utilizando apenas um elemento de processamento. Espera-se ganhar desempenho no sistema como um todo, mesmo que algumas aplicações tenham seus tempos aumentados, se comparado a um sistema monoprocessado [1];

Computação Paralela Distribuída: Esse ambiente caracteriza-se por utilizar o melhor das duas abordagens anteriores, em que aplicações são executadas de forma paralela sobre um sistema único distribuído do tipo Multiple Instruction Multiple Data (MIMD) [4].

\section{$2.2 \quad$ Clusters}

Os clusters são caracterizados pelo agrupamento de vários computadores ${ }^{2}$, através de uma conexão de rede, podendo estar em um laboratório ou mesmo espalhados por um campus universitário [1]. O conceito de cluster se restringe apenas ao hardware e ao sistema operacional, necessitando de um ambiente de software (middleware ou ambientes de programação) para dar origem aos sistemas distribuídos.

Atualmente não existe uma classificação aceita para os clusters, porém algumas características encontram-se na figura 2.1 e uma explanação das mais importantes será realizada nas seções seguintes.

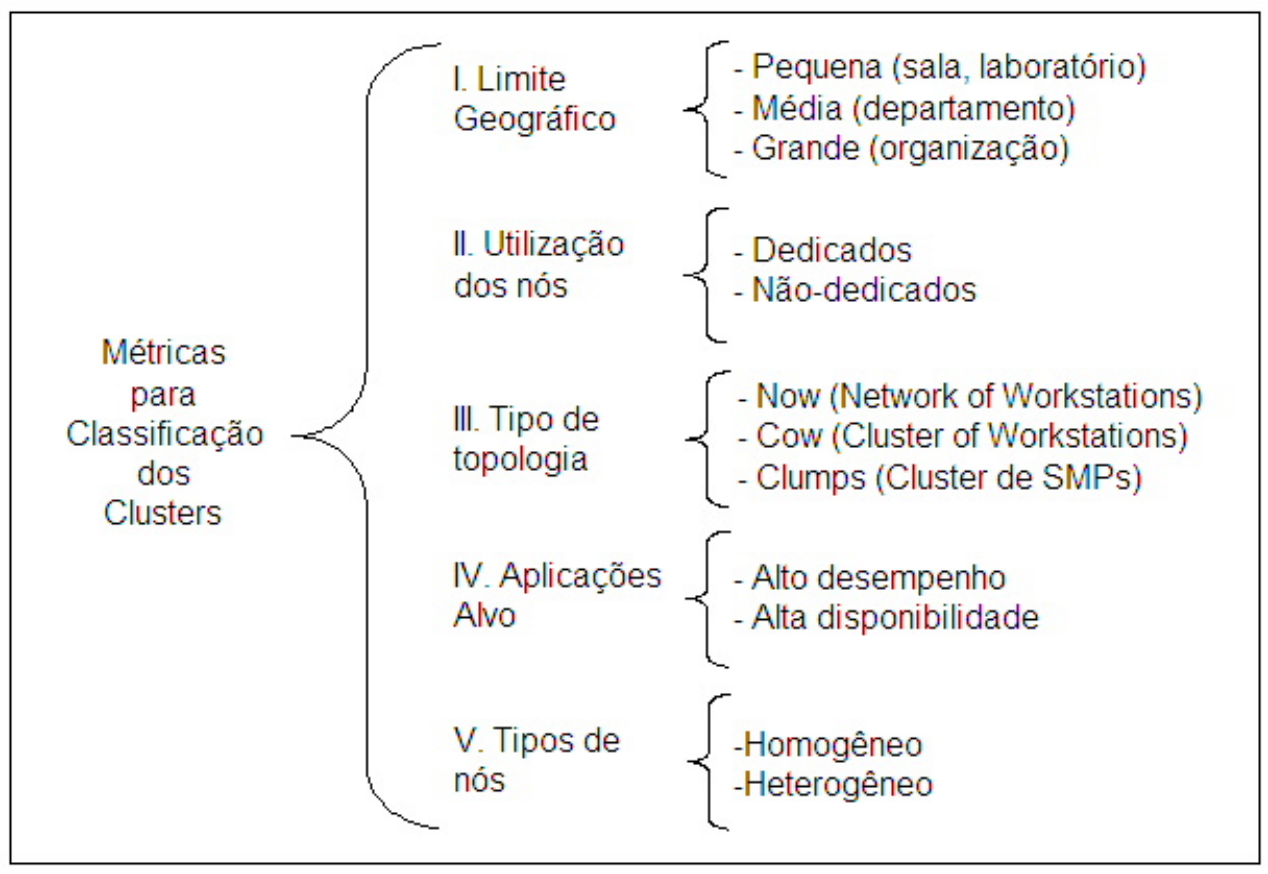

Figura 2.1: Características dos clusters computacionais [1].

\footnotetext{
${ }^{2}$ Os computadores que compõem o cluster também são conhecidos como nós.
} 


\subsubsection{Utilização dos nós}

Essa característica dos clusters é uma das mais importantes, influenciando diretamente nas políticas de escalonamento e no tempo de resposta das aplicações.

Um cluster é dito dedicado quando não há a presença de usuários interativos. Dessa forma, o ambiente é disponibilizado totalmente para a execução de aplicações. Ao contrário, um cluster não dedicado possui usuários interativos, assim, o tempo de resposta das aplicações depende da maior ou menor presença de usuários on-line.

\subsubsection{Tipo dos nós}

A heterogeneidade pode ser de vários tipos:

Configuracional: Todos os nós do ambiente possuem a mesma arquitetura, porém com quantidades diferentes de recursos. Exemplos dessa categoria são máquinas compostas por processadores com frequências diferentes e/ou diferentes quantidades de memória principal;

Arquitetural: As máquinas que formam o ambiente são de diferentes arquiteturas de hardware, como máquinas RISC (Reduced Instruction Set Complex) e CISC (complex instruction set computer) ;

Sistema operacional: O sistema operacional dos nós são distintos [9].

As heterogeneidades arquitetural e de sistema operacional são as mais críticas, dificultando a execução de um mesmo código em máquinas diferentes. Já a heterogeneidade configuracional dificulta apenas a atividade do escalonador.

Um cluster é dito homogêneo quando não existe qualquer tipo de heterogeneidade.

\subsubsection{Topologia}

Muitos autores classificam os clusters de acordo com o hardware utilizado. A categoria mais popular corresponde às NOWs, que são sistemas formados por estações de trabalho ou computadores pessoais, conectados por uma rede de comunicação e disponíveis para executar aplicações paralelas, podendo ter máquinas heterogêneas e usuários interativos $[2]$.

Na segunda categoria encontram-se os Cluster of Workstations (COWs). Estes, ao contrário das NOWs, são constituídos de máquinas homogêneas e dedicadas à aplicação, sem a presença de usuários interativos [10]. 
Os Cluster of SMPs (Clumps), são ambientes compostos unicamente por máquinas com arquitetura Symmetric Multiprocessing (SMP) [1].

\section{$2.3 \quad$ Grid}

Os grids computacionais constituem outra forma de agrupamento de máquinas para compartilhar recursos. Esse agrupamento representa a interoperabilidade entre ambientes computacionais heterogêneos dispersos, em que o usuário acessa o ambiente através de uma interface única [1]. Ao contrário dos clusters, os grids não pertencem a uma mesma administração, podendo ser, inclusive, um consórcio entre instituições (universidades por exemplo).

Um grid computacional pode estar instalado ao redor do mundo, pertencendo a várias instituições com vários usuários. Por esse motivo os grids apresentam grandes complicações, como o monitoramento de recursos disponíveis, a migração de aplicações e o balanceamento de carga.

\subsection{Ambientes de software}

Para que as aplicações paralelas e/ou distribuídas possam ser executadas com sucesso nos clusters, é necessário a presença de um ambiente de software. Os dois ambientes mais utilizados são os de programação e os middlewares [1].

\subsubsection{Ambientes de programação}

Nos ambientes de programação a comunicação entre os processos é de responsabilidade do programador, utilizando bibliotecas com funções específicas para esse propósito. Existem na atualidade vários pacotes de softwares que disponibilizam esse recurso. Entretanto, dois deles merecem destaque, uma vez que são os mais utilizados: Parallel Virtual Machine (PVM) e Message Passing Interface (MPI).

O PVM é um pacote integrado de bibliotecas e ferramentas de software que visa prover os recursos de um ambiente de programação paralela e uma forma transparente de agregar inúmeras máquinas. Tal ambiente possui primitivas para manipulação de processos e alocação de nós, usando passagem de mensagem para a comunicação.

O PVM é composto por duas camadas, como apresentado na figura 2.2. A primeira é a biblioteca que deve ser inserida no código da aplicação, fornecendo as primitivas para 
a troca de mensagens; o segundo é um daemon (pvmd), que cria a abstração de uma máquina paralela virtual para os programadores [11].

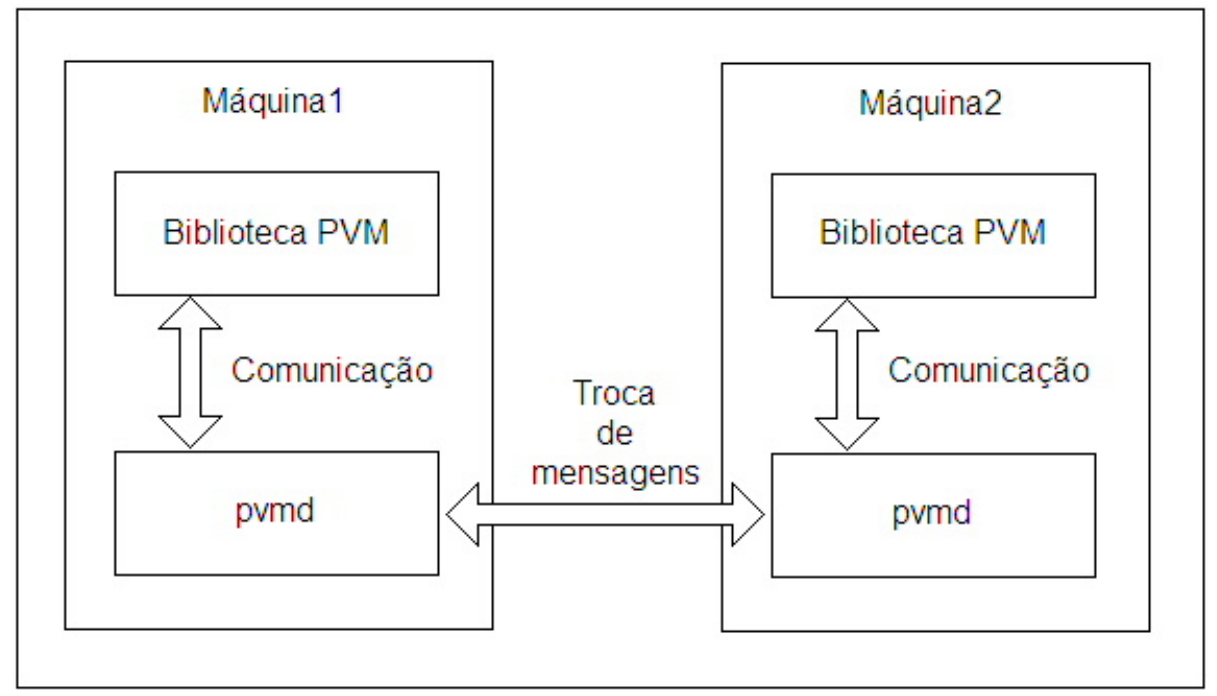

Figura 2.2: Estrutura PVM.

O MPI, por sua vez, não implementa um ambiente completo, constituindo apenas um padrão para a troca de mensagens para aplicações que utilizam computadores MIMD com memória compartilhada [11]. Por fornecer apenas a biblioteca com as rotinas para trocas de mensagens, que deve ser inserida no código como o PVM, o MPI necessita de um ambiente computacional paralelo, como o fornecido pelo daemon pvmd.

\subsubsection{Middlewares}

Middlewares podem ser definidos como uma camada de software existente entre as aplicações do usuário e o sistema operacional, oferecendo certas estruturas de dados e operações, permitindo o relacionamento, em grupo, de processos e usuários em máquinas distantes, de modo consistente e uniforme, na presença de diferentes arquiteturas de hardware e sistemas operacionais [4].

Existem vários tipos de middlewares disponíveis e destaque deve ser dado aos de imagem única. Nesse modelo algumas funções do sistema operacional são transferidas para o middleware, fornecendo para o usuário uma transparência de localização de recursos e serviços, visando à melhora de desempenho [1]. Assim, toda aplicação do usuário é submetida primeiramente ao middeware, que possui rotinas de comunicação com o sistema operacional, através de troca de mensagens, permitindo fornecer ao usuário um ambiente homogêneo e único, já que a submissão para execução remota e a migração dos processos, caso exista, será realizada por essa camada intermediária. Um esquema desse tipo de middleware pode ser observado na figura 2.3. 


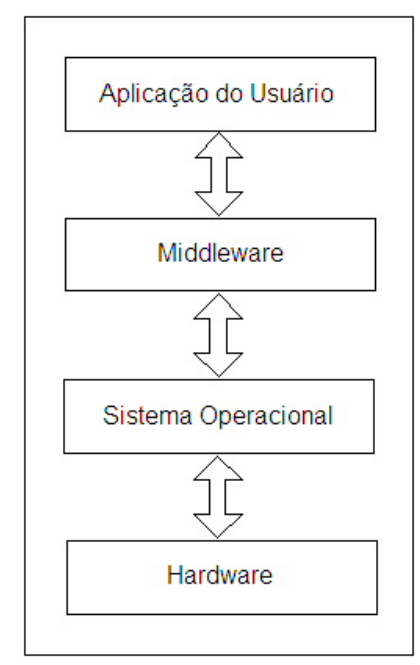

Figura 2.3: Middleware de imagem única.

Atualmente, um dos sistemas middlewares para clusters mais conhecido, e de interesse para este trabalho, é o openMosix. Ele constitui uma extensão do kernel do Linux, transformando uma rede comum de computadores em um supercomputador. Após ser inicializado nas máquinas, os processos openMosix trocam informações, para identificar os nós disponíveis e, constantemente, trocam informações para balancear a carga submetida ao cluster, permitindo, a qualquer instante, que máquinas sejam adicionadas e retiradas do sistema [12].

Nesse ambiente, o usuário não precisa desenvolver aplicações para openMosix, já que ele é uma extensão do kernel do Linux e fornece um ambiente único e transparente.

É interessante destacar que o balanceamento de carga executado pelo openMosix é baseado em memória, já que o middleware procura deixar o máximo de memória principal disponível no sistema. Assim, se uma aplicação for submetida a um nó sobrecarregado, ela será executada remotamente em outro com menor carga. O mesmo ocorre durante a execução de uma tarefa, em que a máquina se sobrecarrega, migrando a aplicação sem perder a computação já executada.

\subsection{Considerações finais}

A caracterização dos sistemas distribuídos é de fundamental importância para o desenvolvimento deste trabalho, uma vez que estes possuem como objetivo o compartilhamento de recursos e não a redução do tempo de execução de uma aplicação, como os sistemas paralelos. No entanto, ao realizar o balanceamento de carga, espera-se obter reduções nas perdas de desempenho sofridas pelas aplicações, já que os recursos serão distribuídos de maneira otimizada. 
Para a obtenção de um sistema distribuído, completo e funcional, é necessária a presença de uma camada de software acima do sistema operacional, pois sem ela, o usuário continuará na dependência da distribuição manual dos processos pelos nós do cluster.

Essa camada pode ser formada de duas maneiras. A primeira utiliza bibliotecas de programação, assim, é necessário que o código do programa contenha instruções específicas para o envio de processos pela rede e também para a troca de mensagens. Os sistemas de imagem única, denominados middlewares, ao contrário, permitem que os programadores utilizem chamadas tradicionais ao sistema, como fork, para distribuir processos entre os elementos de processamento, diminuindo a complexidade de implementação de programas concorrentes.

Para ambos os sistemas de softwares, descritos acima, são necessários políticas de escalonamento que serão responsáveis por decidir para qual nó enviar o processo recentemente criado, assim, o próximo capítulo abordará esse assunto, descrevendo, em detalhes, a composição e funcionamento de um escalonador. 
Capítulo

3

\section{Escalonamento}

\subsection{Considerações iniciais}

Com o surgimento da computação distribuída vários obstáculos foram encontrados e hoje são objetos de estudos.

O desenvolvimento de técnicas e métricas eficientes para distribuir processos a nós do sistema é uma área tradicional em sistemas distribuídos, que ainda não foi totalmente explorada, sendo alvo de muitas pesquisas [13]. Um dos fatores responsáveis pela atenção dada a essa atividade em plataformas distribuídas é a relação custo/benefício.

Essa tarefa de distribuição, conhecida como escalonamento de processos, visa a atingir um conjunto de objetivos, tais como: melhorar o compartilhamento de recursos, melhorar o tempo de resposta, realizar balanceamento de carga. Para atingir essas metas, o software responsável pela tarefa de atribuição de processos aos nós (escalonador), deve tomar decisões baseadas em fatores tais como a carga de trabalho no sistema, a presença de aplicações com diferentes características, o hardware de rede, o sistema operacional nativo de cada nó [14].

Em plataformas distribuídas o escalonamento local é deixado a cargo do sistema operacional, dessa forma o escalonador deve tratar apenas do escalonamento global, que pode ser definido como a tarefa de distribuir processos entre os elementos de processamento, visando a atingir alguma meta [15]. Já o escalonamento local é compreendido como a tarefa de gerenciar vários processos executando concorrentemente sobre um único processador, 
atribuindo fatias de tempo ${ }^{1}$ para os processos [4].

Consumidores, recursos e escalonador, são os três componentes envolvidos na atividade de escalonamento global [16].

O escalonador, através das políticas, visa a atribuir recursos aos consumidores, de maneira ordenada e eficiente. Os recursos são processadores, memórias, discos, redes de comunicação etc. Os consumidores, por sua vez, são aplicações seqüenciais ou paralelas de usuários. Esses componentes podem ser visualizados na figura 3.1, que destaca também a seqüência de comunicação entre eles.

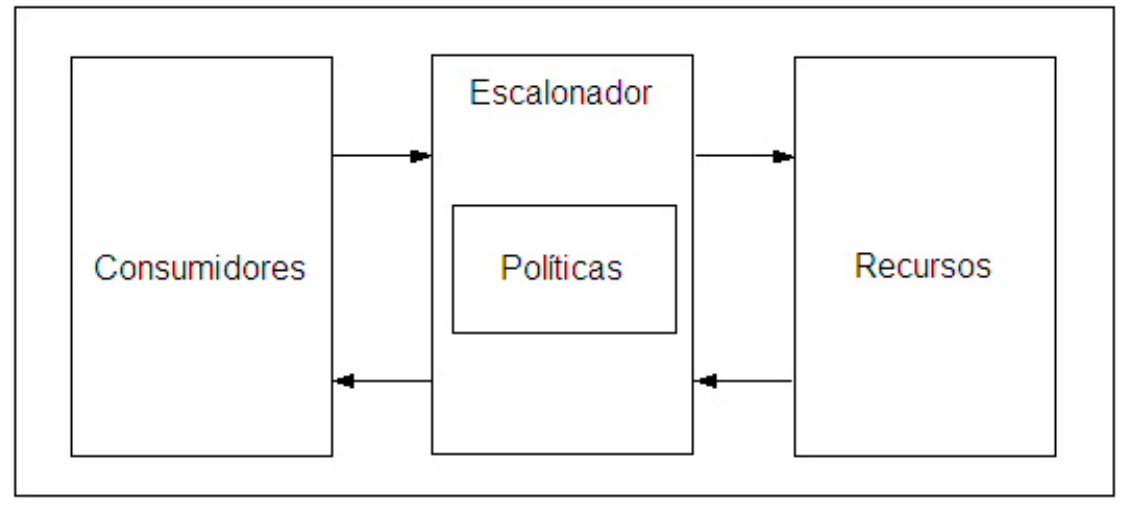

Figura 3.1: Componentes envolvidos no escalonamento [16].

\subsection{Composição do escalonador}

Não existe um consenso na comunidade científica sobre a composição típica de um escalonador, no entanto a classificação mais aceita divide o escalonador em políticas e mecanismos, conforme figura 3.2.

As políticas são responsáveis por decidir quando o escalonamento deve ser executado, qual tarefa deve ser retirada do nó e se a mesma deve ser enviada para execução remota ou migrada. Assim, entende-se que as políticas são responsáveis pelas regras a serem cumpridas, determinando através dos objetivos quais e quando os mecanismos devem ser utilizados. Já os mecanismos são responsáveis por definir como o escalonamento será efetuado, utilizando instruções que podem ser interpretadas como ferramentas [17].

\subsubsection{Políticas}

Inicialmente é necessário identificar se um determinado nó do cluster está apto a participar de uma transferência de processos, seja como receptor ou transmissor, por possuir

\footnotetext{
${ }^{1}$ Cada fatia de tempo é denominada quantum.
} 


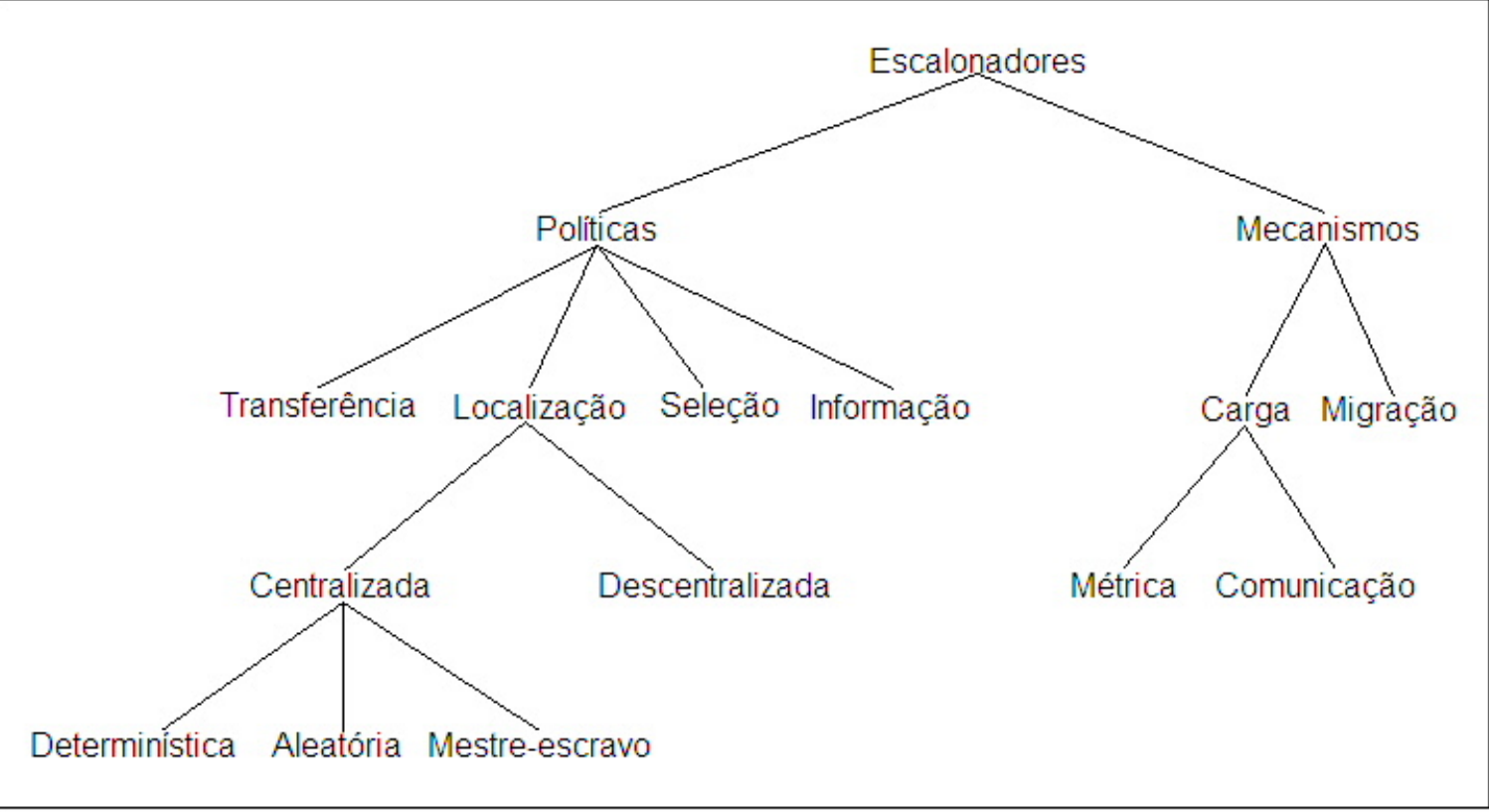

Figura 3.2: Composição dos escalonadores [8].

pouca ou muita carga, respectivamente. Essa é a função da política de transferência, que pode ser relativa ou baseada em limites.

Na modalidade relativa, uma comparação é realizada entre as cargas dos nós. Assim, se uma máquina possui carga de trabalho $\delta$ vezes menor que outra, ela é classificada como receptora e a outra como transmissora.

Quando baseada em limites, duas constantes $\tau 1$ e $\tau 2$ devem ser definidas. Baseado nisto, se um nó tiver carga de trabalho inferior à primeira constante, ele é classificado como receptor, caso sua carga seja superior a $\tau 2$ ele é dito transmissor. Ambas as constantes podem ser iguais, dependendo do objetivo a ser alcançado.

Logo após determinar que uma transferência deve ocorrer, cabe à política de seleção escolher qual processo será transferido, devendo dar a preferência para processos que ainda não executaram por nenhum quantum, caso contrário deverá ser feita uma análise para verificar o ganho na transferência, uma vez que esta envolve muitos parâmetros a serem transferidos, tais como a tabela do processo, imagem da memória entre outros.

A partir desse ponto já existe a necessidade de realizar a transferência e se conhece qual processo dever ser transferido. Assim, cabe à política de localização encontrar outro nó para realizar a transferência, seja ele receptor ou transmissor. Existem duas abordagens para realizar essa tarefa: na primeira, denominada de centralizada, a consulta é feita a um nó específico, chamado de coordenador, que localiza outro nó apto a participar da transferência ao contrário da descentralizada que procura outro nó através de tentativas, interrogando outros para verificar se algum aceita participar de uma transferência, seja 
para receber ou transmitir processos.

A abordagem centralizada pode ser de três grupos [8]:

Determinística: Adota-se um regra matemática pré-estabelecida para determinar o nó que receberá o processo, baseado apenas no estado atual e na tarefa a ser escalonada;

Aleatória: A atribuição da tarefa a um nó é determinado de forma aleatória, podendo a máquina de destino migrá-la novamente, caso esteja congestionada;

Mestre-escravo: Nessa abordagem um processo denominado mestre, cria outros processos escravos em máquinas remotas, sendo o responsável por definir qual processo receberá dados para serem processados.

Para verificar se um nó deve ou não participar de uma migração, a política de transferência necessita de informações sobre o sistema, caracterizando a função da política de informação, que determina qual, quando e onde uma informação deve ser coletada, disponibilizando-a para uso futuro. Nessa política definem-se quais os parâmetros devem ser considerados para o escalonamento.

A política de informação pode ser de três tipos [17]:

Orientada a demanda: Nessa categoria a política coleta informações de outras máquinas quando ela se torna uma receptora ou emissora;

Periódica: As informações de outros nós são coletadas em intervalos de tempos pré fixados;

Orientada a mudança de estado: Quando ocorre uma mudança de estado, a máquina informa as outras através de mensagens.

\subsubsection{Mecanismos}

Os mecanismos podem ser divididos em dois grupos [8]:

Carga: É responsável por definições que envolvam a carga das máquinas que compõem o sistema, dividindo-se em duas especialidades:

Métrica: Define o método que será utilizado para medir a carga no sistema;

Comunicação: Indica o método que será utilizado para troca de informações entre os nós do sistema, como exemplo podem-se citar mensagens por broadcast. 
Migração: Deve definir como será o mecanismo utilizado para realizar a migração de processos ou execução remota. Várias estratégias são adotadas nesse mecanismo, como migrar todos os dados do processo e então iniciar sua execução na máquina remota, ou migrar apenas a parte mínima, suficiente para iniciar a execução no host remoto; à medida que ausências de páginas ocorrem os dados remanescentes serão migrados.

\subsection{Classificação dos escalonadores}

Com o grande número de trabalhos desenvolvidos na área de escalonamento de processos, é inevitável que várias terminologias sejam utilizadas, sendo muitas vezes contraditórias e inconsistentes entre si, dificultando a análise das mais diversas abordagens apresentadas [8].

Nesse contexto várias taxonomias surgiram, sendo que duas dessas merecem destaque no contexto deste trabalho, devido ao elevado número de citações e pela abrangência apresentada. A taxonomia de Casavant e Kuhl (1988), que trata de escalonamento distribuído, e a taxonomia de Feitelson e Rudolph (1995), que é direcionada à computação paralela.

Ambas as classificações são importantes para a compreensão dos capítulos seguintes e, por este motivo, terão suas características principais descritas neste texto. Todavia, faz-se necessário definir previamente escalonamento, no contexto da computação paralela e em sistemas distribuídos.

\subsubsection{Escalonamento paralelo versus distribuído}

O escalonamento de processos, na computação paralela, trata um problema de otimização da utilização de recursos pelos processos, enquanto em sistemas distribuídos o problema a ser tratado é o gerenciamento de recursos, considerando as várias requisições de diversos usuários [18].

Para obter paralelismo nas aplicações, deve-se utilizar a programação concorrente, onde uma aplicação é dividida em vários processos e/ou threads, que executam funções independentes ao mesmo tempo, devendo estar sobre um conjunto de elementos de processamento para caracterizar a computação paralela. Nesse contexto, o escalonador deve gerenciar a carga e atribuir às aplicações conjuntos de processadores, de maneira a otimizar a utilização da plataforma e o desempenho das aplicações, não permitindo a perda da concorrência. Nesse contexto encontram-se normalmente equipamentos com vários proces- 
sadores com memória distribuída, focando a atribuição dos processadores da arquitetura às aplicações.

Na computação distribuída encontram-se aplicações seqüenciais ou paralelas que podem ser submetidas aos mais diversos nós do sistemas, sendo necessário alocar recursos para processar e atender as necessidades dessas tarefas, podendo a aplicação ser executada em qualquer nó da plataforma [1]. Dessa forma, cabe ao escalonador selecionar o melhor nó para executar uma tarefa, otimizando a carga do sistema e também o tempo de resposta das tarefas, bem como outros objetivos como o balanceamento de carga. O escalonamento distribuído gerencia nós do sistema, independente de serem formados por máquinas paralelas ou não.

\subsubsection{Taxonomia de Casavant e Kuhl (1988)}

Essa taxonomia trata do escalonamento distribuído de processos, com o objetivo de unificar as terminologias existentes na época, permitindo uma rápida descrição dos aspectos centrais de um escalonador em uma pesquisa em particular, criando uma base de comparação entre as propostas existentes [16].

O esquema apresentado por Casavant e Kuhl é composto por uma classificação hierárquica, que mantém uma relação de procedência entre os componentes, e outra plana, onde os componentes não apresentam esta relação, sendo analisados independentemente.

\subsubsection{Classificação hierárquica}

Um esquema desta classificação pode ser observado na figura 3.3.

Local versus global: Essa taxonomia classifica apenas o escalonamento global, já que o local deve ficar a cargo do sistema operacional, como citado anteriormente. O escalonamento global trata a alocação de recursos a processos, tais como processador, disco, memória, rede de comunicação entre outros.

Estático versus dinâmico: Essa classificação refere-se ao momento em que o escalonamento é determinado.

O escalonamento estático é realizado em tempo de compilação. Assim, uma grande quantidade de informações sobre as aplicações e o ambiente devem estar disponíveis no ato da link edição, uma vez que a seqüência de submissões das tarefas aos processadores é predefinida, não sendo alterada mesmo que o ambiente venha a ficar congestionado. Desta forma, a escassez de informações pode levar a uma combinação ruim de atribuição, levando o sistema ao estado de trashing. Essa modalidade de 


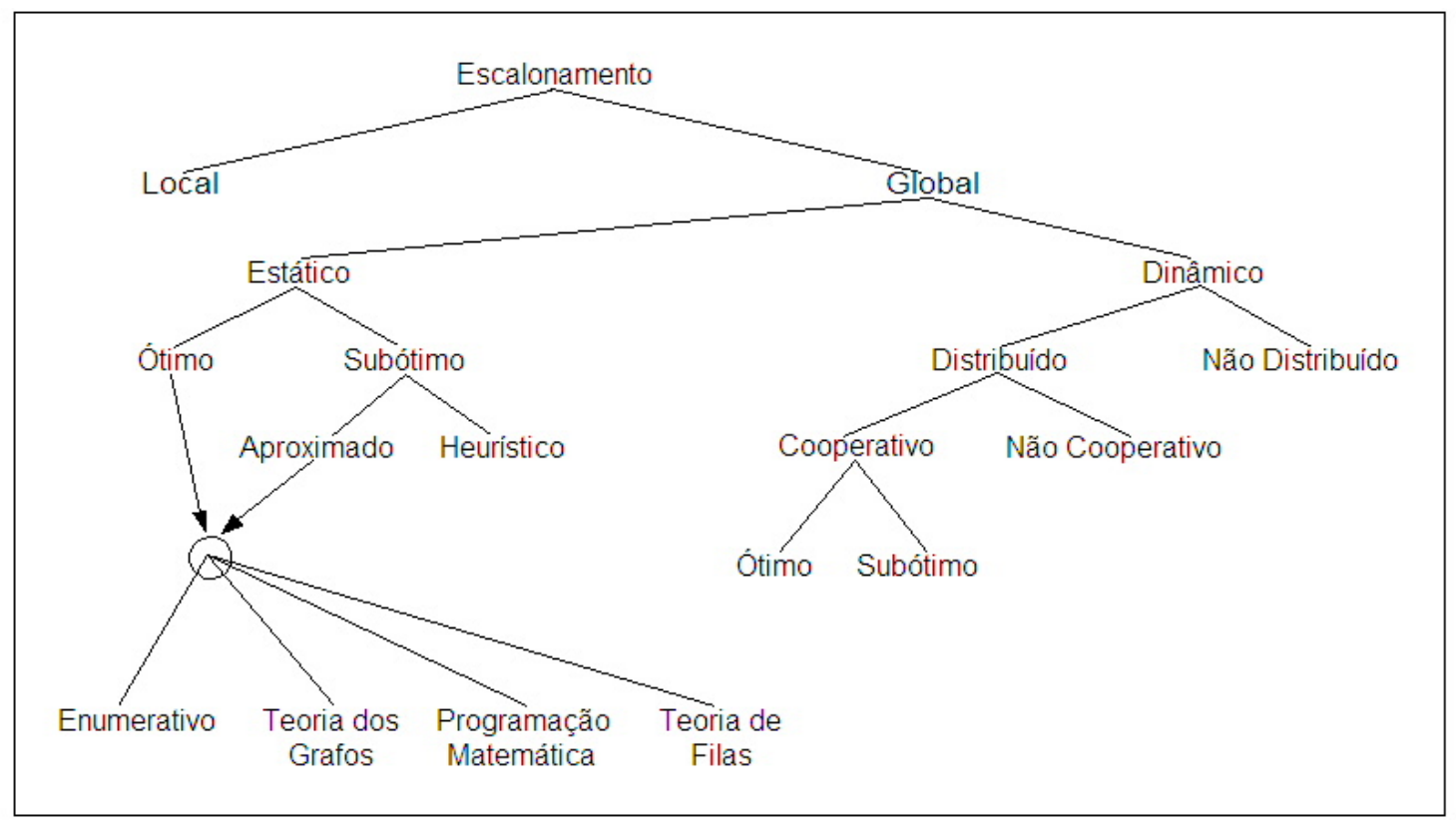

Figura 3.3: Taxonomia proposta em [16], apresentando uma classificação hierárquica.

escalonamento pode ser realizada pelos desenvolvedores da aplicação, bem como por códigos específicos, que analisam sintática e semanticamente o código da aplicação [14].

Sua vantagem, sobre o mecanismo dinâmico, é a ausência da sobrecarga gerada no sistema, já que o escalonamento está pronto antes de ser iniciada a execução das tarefas. Entretanto, nem sempre a grande quantidade de informações necessárias para atingir o melhor desempenho do sistema estão disponíveis. Outros pontos negativos são a falta de flexibilidade, portabilidade, tolerância a falhas e escalabilidade.

Em contrapartida, o escalonamento dinâmico é definido durante a execução da aplicação, não sendo necessária uma grande quantidade de informações sobre as aplicações, já que o foco do escalonador está na plataforma e não nas tarefas. Essa modalidade de escalonamento analisa a plataforma durante a execução das tarefas, permitindo readaptar a atribuição de processos, com o intuito de alcançar o objetivo implícito no software do escalonador.

Ao contrário do escalonamento estático, o dinâmico é flexível, portável, tolerante a falhas, escalar e gerencia os usuários simultâneos. Sua principal desvantagem é a sobrecarga gerada no sistema, devido às decisões tomadas e a coleta de informações da plataforma [8].

Aproximado versus heurístico: Na classificação "aproximado" encontram-se os algoritmos que utilizam um modelo computacional formal para escalonar, porém buscando apenas uma boa solução, e não a ótima, sendo tratado muitas vezes, na literatura, como solução subótima-aproximada. 
Há quatro fatores principais que determinam a utilização dessa abordagem [16]:

1. A disponibilidade de uma função que leve à solução do escalonamento;

2. O tempo requerido para avaliar e determinar a solução;

3. A habilidade de julgar de acordo com alguma métrica o valor de uma solução ótima;

4. A disponibilidade de um mecanismo para aparar inteligentemente o espaço da solução.

A abordagem heurística procura melhorar o desempenho da plataforma através de parâmetros que estão relacionados indiretamente com ela, tornando os cálculos e monitoramentos necessários mais simples. Essa abordagem apresenta tempo de resposta significativamente maior, já que mais informações devem ser coletadas e analisadas, no entanto, representa a parcela mais realista das abordagens presentes na literatura.

Casavant e Kuhl (1988) citam como exemplo da abordagem heurística a separação, em blocos distintos de processadores, dos processos que utilizam muita comunicação em rede (communication-intensive), daqueles que utilizam paralelismo, diminuindo assim o impacto da troca de mensagens, que seria somada à comunicação resultante do primeiro grupo.

Distribuído versus não distribuído: No esquema "não distribuído" o trabalho referente ao escalonamento dinâmico global reside em apenas um nó, ao contrário do fisicamente distribuído, em que o trabalho de distribuição de processos a processadores, reside em mais de um computador.

Cooperativo versus não cooperativo: Os algoritmos distribuídos podem ser caracterizados pela cooperação, ou não, entre os mecanismos. Na categoria "não cooperativo", as políticas em cada elemento de processamento tomam as decisões de escalonamento individualmente, independente do impacto causado na plataforma, focando somente o ganho de desempenho local, esperando que ocorra o reflexo dessa melhoria também na plataforma. Por outro lado, na categoria cooperativo, as políticas tomam decisões para melhorar o desempenho da plataforma, independente do resultado no processador local.

Um exemplo de escalonamento distribuído cooperativo é o algoritmo Assign-u, descrito em [19], que define uma equação de custo, que é recalculada na chegada de uma tarefa, para todos os processadores, sendo o de menor valor o receptor da aplicação submetida. 


\subsubsection{Classificação plana}

Juntamente com a classificação hierárquica citada, existem algumas outras características que são importantes para classificar um sistema de escalonamento.

Adaptável versus Não adaptável: Uma solução adaptável é aquela em que os algoritmos e parâmetros utilizados na implementação da política de escalonamento modificam-se dinamicamente, de acordo com o estado passado e atual da plataforma. Assim, um parâmetro a ser analisado pode se tornar mais ou menos importante, dependendo do histórico do escalonamento, podendo até ser desconsiderado. Ao contrário, uma solução não adaptável é aquela em que os algoritmos e parâmetros não são modificados, mesmo que a situação atual da plataforma tenha sido consideravelmente modificada em comparação com seu passado.

Atribuição simples versus reatribuição dinâmica: A atribuição simples ${ }^{2}$ é caracterizada pela análise única ao atribuir um processo, quando o mesmo chega ao sistema. Essa análise indica o melhor processador para inserir o processo naquele momento (chegada), porém, o sistema pode ter suas características de carga alteradas, devido às variações na plataforma computacional e nenhuma análise posterior será feita com relação aos processos já atribuídos, cabendo ao escalonador analisar apenas os processos que estão chegando.

Reatribuição dinâmica ou migração de processos, como é mais conhecida, é a transferência de um processo alocado em um processador para outro, corrigindo uma atribuição inicial que tornou-se "incorreta" devido à variação da carga inserida no sistema . Essa atividade utiliza um escalonamento preemptivo, já que a execução do processo deve ser encerrada na máquina atual e reinicializada na máquina destino. Nesse contexto há a necessidade de checkpoint, que permite salvar o estado do processo, permitindo o reinício da sua execução na máquina destino a partir do ponto em que foi interrompido.

Para migrar um processo é necessário inicialmente decidir qual deve ser migrado, suspender sua execução, gravar seu estado através do checkpoint, transmitir o estado para a máquina de destino reconstruindo-o e reiniciando-o. Somente após finalizar os passos anteriores é que o processo será destruído na máquina de origem.

Entre as motivações que levam ao estudo da migração de processos estão o balanceamento dinâmico de carga, o compartilhamento de recursos e a administração do sistema. Dentre os citados, destaque deve ser dado ao primeiro, pois contribui com o aumento de desempenho da plataforma, uma vez que o processo pode ser retirado, durante a sua execução, de um processador congestionado.

\footnotetext{
${ }^{2} \mathrm{~A}$ atribuição simples é conhecida atualmente como execução remota.
} 
O custo da migração de processos deve ser levado em consideração, bem como os mecanismos utilizados, o que deu origem a uma importante e complexa linha de pesquisa [6].

\subsubsection{Taxonomia de Feitelson e Rudolph(1995)}

Esta taxonomia é direcionada à computação paralela, dividindo os algoritmos de escalonamento em dois grandes grupos: time sharing e space sharing. Na primeira categoria estão os algoritmos que utilizam o tempo para realizar o escalonamento e na segunda usam o espaço ${ }^{3}$. A segunda categoria é mais importante para o contexto deste trabalho, dessa forma, somente ela será abordada.

Nesta categoria, uma aplicação recebe um conjunto de processadores, ou um subconjunto, na sua submissão e executa até seu termino. Dessa maneira, há um ganho de desempenho, já que a tarefa aloca recursos computacionais com exclusividade [20].

Esta abordagem não poderá ser aplicada sem um conjunto de software, que deve isolar o conjunto de processadores atribuídos a uma aplicação, permitindo a utilização dedicada destes recursos, porém, deve ser evitada a situação em que a aplicação submetida necessite de todos os processadores da plataforma, já que ela pode entrar em starvation, pois, dificilmente todos os processadores se tornarão disponíveis ao mesmo tempo.

Os autores descrevem o particionamento variável como uma das principais políticas para essa categoria de algoritmo. Essa política divide os processadores das plataformas em grupos, atribuindo cada tarefa à um grupo distinto. Essas partições podem ser criadas e gerenciadas de quatro formas distintas, como mostra a tabela 3.1.

\begin{tabular}{|l|c|c|c|}
\hline \multicolumn{1}{|c|}{$\begin{array}{c}\text { Tipos de } \\
\text { particionamento }\end{array}$} & $\begin{array}{c}\text { Solicitado pelo } \\
\text { usuário }\end{array}$ & $\begin{array}{c}\text { Carga } \\
\text { computacional }\end{array}$ & $\begin{array}{c}\text { Alteração na } \\
\text { partição }\end{array}$ \\
\hline Fixo & Não & Não & Não \\
\hline Variável & Sim & Não & Não \\
\hline Adaptável & Sim & Sim & Não \\
\hline Dinâmico & Sim & Sim & Sim \\
\hline
\end{tabular}

Tabela 3.1: Formas de particionamento variável [7]

A partição fixa é determinada na inicialização do sistema, através de configurações manuais realizadas pelo administrador. Dessa forma, as partições somente podem ser refeitas através de uma nova inicialização da plataforma. Esse tipo de partição é o mesmo utilizado no artigo [21], que comprova a importância de se considerar informações de memória principal no escalonamento de processos, como será mostrado no capítulo 4.

\footnotetext{
${ }^{3}$ Conjunto de processadores disponíveis no sistema.
} 
Esse formato é extremamente veloz, uma vez que definidas as partições, elas não necessitam ser refeitas, evitando assim o tempo gasto com análise da situação atual da plataforma e das necessidades das aplicações que estão sendo submetidas. No entanto, dependendo da aplicação, as partições podem ofertar poucos ou muitos processadores, o que pode prejudicar o tempo de resposta da tarefa, aumentando a perda de desempenho global do sistema.

Na partição variável, o particionamento ocorre no momento da submissão da aplicação, alocando apenas a quantidade de processadores necessários. Ao término da execução, o bloco de processadores, antes ocupado, passa a fazer parte do grande bloco de processadores livres, desfazendo a partição. Esse tipo de particionamento é também conhecido como pure space sharing ou static partitioning (partição estática) [14].

O fato das aplicações executarem em uma espécie de sistema dedicado, criado com base em suas necessidades, evitando a sobrecarga causada pelo sistema operacional, é uma das principais vantagens apresentadas por esse método

A fragmentação de processadores é a principal desvantagem deste esquema, uma vez que os processadores disponíveis podem não ser suficientes para executar as tarefas que estão na fila, tornando-se necessário aguardar outra finalizar, para que mais processadores sejam disponibilizados.

O particionamento adaptável ocorre também no momento de submissão da tarefa, porém a partição é criada com informações baseadas na carga atual da plataforma. Da mesma forma que ocorre na partição variável, a partição adaptável somente é desfeita no término da execução da aplicação, retornando os processadores ocupados para o bloco de processadores livres. Sua principal vantagem é balancear a carga nas partições, já que dependendo da carga do sistema, partições cada vez menores serão criadas. No entanto, um limite deve ser estabelecido, já que, diminuindo muito o tamanho das partições, as aplicações podem perder a eficiência proporcionada pela programação concorrente.

As partições dinâmicas são criadas da mesma forma que a adaptável, porém permitem o redimensionamento durante a execução das tarefas, refletindo um ajuste a carga atual da plataforma. A redefinição das partições deve ser executada somente após ter sua eficiência comprovada, pois sistemas sobrecarregados podem ficar reparticionando constantemente, levando à degradação.

\subsection{Balanceamento de carga em sistemas distribuídos}

$\mathrm{Na}$ literatura não existe um consenso sobre a utilização dos termos escalonamento de processos e balanceamento de carga. Alguns autores os utilizam como sinônimos, outros 
utilizam o termo balanceamento de carga para especificar o escalonamento dinâmico de processos e há aqueles que os utilizam para descrever atividades diferentes [14].

Os algoritmos de escalonamento utilizam muitos artifícios para melhorar algumas características do sistema. Assim, considerar o balanceamento de carga um tipo de algoritmo, limita a quantidade de recursos que podem ser utilizados pelos mesmos. Desta forma, no contexto de trabalho, o balanceamento de carga será considerado uma das metas buscadas pelas políticas.

O balanceamento de carga consiste em distribuir de maneira uniforme os processos aos elementos de processamento, evitando situações em que alguns processadores estejam sobrecarregados, outros com pouca carga e alguns ociosos [8].

O conceito de balanceamento de carga, atualmente, pode ser estendido para qualquer tipo de recurso, como memória principal, rede de comunicação entre outros, assim o balanceamento de carga baseado na memória, procura manter a memória de todos os nós ocupadas de maneira uniforme.

O balanceamento de carga possibilita melhorar o desempenho das plataformas distribuídas, convergindo juntamente com o grande número de processadores presentes para a computação de alto desempenho [1].

Apesar de distribuir de maneira uniforme a carga pela plataforma computacional, cabe à política de escalonamento garantir que a carga atribuída a cada nó não ultrapasse sua capacidade, o que poderia degradar o sistema. Essa tarefa não é trivial, já que cada máquina pode possuir heterogeneidade de arquitetura, de configuração e de sistema operacional, assim como também pode ser desconhecida a quantidade de processadores solicitados por cada aplicação, sem mencionar a presença de usuários interativos, caso o sistema não seja dedicado.

\subsection{Considerações finais}

Os escalonadores utilizam políticas para tomadas de decisão e os métodos para executar as decisões tomadas. Para uma melhor organização e compreensão, as políticas normalmente são divididas em quatro categorias:

- Transferência: Responsável por decidir se um nó deve, ou não, participar de uma troca de processos, seja como receptor ou transmissor;

- Seleção: Essa política é responsável por decidir quais processos serão migrados. Em sistemas que utilizam apenas execução remota essa política selecionará sempre o processo recém-chegado; 
- Localização: Atua em conjunto com a política de transferência, encontrando máquinas que possam participar de uma troca de processos;

- Informação: Responsável pela coleta e disponibilização de informações da plataforma e dos processos.

Ao projetar uma política de escalonamento deve-ser ter em mente o tipo de escalonamento que será utilizado, sendo necessário classificá-lo de acordo com alguma taxonomia existente, destacando a de Casavant e Kuhl, descrita em [16]. Essa taxonomia aborda o escalonamento em plataformas distribuídas através de uma classificação hierárquica.

Nessa taxonomia destaque deve ser dado ao escalonamento global e dinâmico, onde a tomada de decisão é realizada no momento em que uma aplicação é submetida a um nó do sistema, podendo ser analisada de maneira distribuída, ou seja, por todos os nós do cluster ou de maneira centralizada, onde apenas um nó é responsável por tomar as decisões para todos os processos submetidos.

No momento do escalonamento as políticas analisam índices, que quantificam a utilização dos recursos, descrevendo o estado atual da carga no sistema. Por esse motivo, o próximo capítulo abordará este tema. 


\section{Capítulo \\ 4 \\ Índices de carga}

\subsection{Considerações Iniciais}

Um dos objetivos principais dos sistemas distribuídos é o gerenciamento eficiente dos recursos da plataforma, utilizando-se das políticas e métodos de escalonamento para atingi-lo. As políticas necessitam de valores que quantifiquem as propriedades dos recursos podendo, assim, distinguir entre um nó congestionado de um ocioso, enviando as aplicações submetidas para o segundo. A esse valor dá-se o nome de medida e a propriedade a que se refere é dita índice de carga [22].

Os índices de carga são objetos de estudo há muito tempo e continuam sendo atualmente, já que é através deles que um algoritmo obtém sucesso, ou não, no momento do escalonamento. Assim, se o índice não for especificado corretamente, sem ambigüidades, e se não for inserido corretamente no contexto, direcionado aos objetivos do algoritmo, o escalonamento poderá degradar o desempenho da plataforma [8].

Algumas características devem ser observadas para que os índices de carga sejam considerados bons [23]:

1. Refletir o mais próximo possível a carga de um nó;

2. Estimar a carga dos nós ou da plataforma no futuro próximo, uma vez que o tempo de resposta de uma tarefa é influenciada em maior intensidade pelo futuro, do que pelo presente;

3. Ser relativamente estável, desconsiderando ou amenizando as grandes flutuações 
esporádicas;

As cargas são representadas por valores não negativos, iniciando em zero, identificando os recursos ociosos e aumentando à medida que os recursos vão se tornando sobrecarregados. Porém, não existe um consenso sobre o valor máximo que um índice pode atingir [23]. Quantificar a carga de trabalho em uma plataforma distribuída não é uma tarefa trivial, uma vez que não existe apenas uma maneira correta de identificar se um nó está sobrecarregado, com carga moderada ou se está ocioso [24].

Outro fator que dificulta o cálculo dos índices são as unidades de medidas, já que os mais diversos recursos são quantificados por diferentes unidades. Por exemplo, a fila do processador é quantificada em unidades, a quantidade de memória em bytes, a ocupação do processador em porcentagem e a taxa de transmissão da rede em bits por segundo (bps) [25].

Os índices podem, ainda, ser classificados como simples ou compostos [23]. No primeiro grupo, estão os mais simples de serem obtidos e são baseados em apenas um valor, sendo portando mais específicos, refletindo a carga de apenas um recurso, por exemplo a CPU. Esses índices são indicados para escalonar aplicações que utilizam com maior intensidade apenas um recurso e sabe-se, de antemão, de qual recurso se trata.

Os índices compostos são mais genéricos, informando em apenas uma medida a carga de vários recursos, por exemplo a CPU e a memória, sendo, portanto, mais difíceis de serem obtidos e sua obtenção gera maior sobrecarga no sistema. Devem ser utilizados quando não existe muita informação sobre a classe da aplicação ${ }^{1}$ ou se as tarefas se enquadram em mais de uma classe.

Alguns índices compostos podem combinar informações diferentes sobre um mesmo recurso em apenas um valor, como por exemplo a fila da CPU e a sua ocupação [5].

A heterogeneidade configuracional da plataforma também pode ser refletida nos índices. Uma abordagem é a multiplicação da medição feita por um fator corretor, que pode ampliar ou reduzir o valor encontrado. Esse fator pode ser obtido através de informações do próprio equipamento, através de um ajuste manual ou através de benchmarks ${ }^{2}$. Com isso, é possível que se evite atribuir aplicações às máquinas ociosas, porém, com baixa capacidade, enquanto houver outras disponíveis com maior capacidade, desde que não estejam sobrecarregadas e possuam recursos para tratar a tarefa que será recebida. Esse tipo de decisão deve levar em consideração previsões sobre o tempo de processamento da aplicação submetida [5].

\footnotetext{
${ }^{1}$ Ver seção seção 4.2 .

${ }^{2}$ Softwares destinados a quantificar a capacidade dos recursos através de testes específicos e consolidados na área de concentração.
} 


\subsection{Classes de aplicações}

Algumas aplicações utilizam com mais freqüência alguns recursos e se comportam de maneiras distintas, quando estão em execução. Essas diferenças tendem a agrupar as tarefas em classes que preferencialmente, devem ser levadas em consideração pelo algoritmo de escalonamento, com o objetivo de melhorar o desempenho do sistema, já que alguns recursos podem estar sobrecarregados, enquanto outros não. Na figura 4.1 apresenta-se uma visão geral dessa classificação.

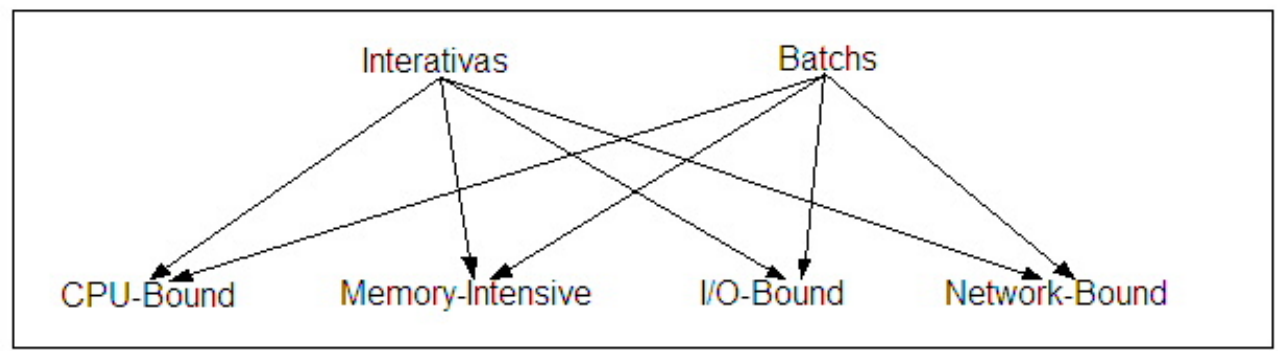

Figura 4.1: Classificação das Aplicações [8].

Inicialmente, as aplicações podem ser classificadas de acordo com o método de execução [26]:

Interativas: Caracterizam-se pela interação da aplicação com o usuário, podendo ser menos ou mais interativas, dependendo da freqüência em que essa interação ocorre. Para esta classe de aplicações o tempo de resposta é um dos fatores mais importantes, devendo ser priorizado no momento do escalonamento;

Batch: Neste grupo estão as aplicações que são submetidas em lote, não havendo interação com usuários. O tempo de execução torna-se fator primordial para esta classe. As políticas direcionadas a esta classe podem ser mais flexíveis e considerar mais fatores para realizar o escalonamento, por não possuírem usuários on-line.

De acordo com a intensidade de utilização dos recursos as aplicações podem ser classificadas em [5]:

$\boldsymbol{C P U}$-bound: Nesta categoria enquadram-se as aplicações que realizam processamento a maior parte do tempo, mantendo o processador ocupado desde o momento em que são escalonadas para execução. Aplicações baseadas em métodos matemáticos, de concentração nas áreas de engenharia, física e biologia são exemplos típicos desta categoria. O termo computation-intensive também é utilizado para este tipo de aplicação. 
Memory-Intensive: Esta categoria de aplicações é objeto de estudo deste trabalho e caracterizam-se pela necessidade de grande quantidade de memória principal. Não existe uma porcentagem limite de ocupação que caracterize este grupo, no entanto, as tarefas que passam tempo considerável escrevendo e lendo na memória, ou que armazene grande quantidade de dados, podem ser categorizados como memoryintensive.

É natural que aplicações memory-intensive também sejam consideradas $C P U$-bound, pois, juntamente com o armazenamento de grandes quantidades de dados, deve haver o processamento dos mesmos.

Estas aplicações também são conhecidas como memory-bound, porém esta denominação é menos utilizada. Exemplos de aplicações desta categoria são programas de data mining, buscas em grandes bases de dados, reconhecimento de voz, processamento de vídeo, modelos climáticos entre outros.

I/O-bound: Quando as aplicações necessitam armazenar, ou ler, muitas informações de dispositivos de armazenamento secundário, passando a maior parte do tempo realizando operações de $I / O$, diz-se que estas aplicações são $I / O$-bound, que também podem ser denominadas I/O-intensive, porém, esta denominação é utilizada com menor freqüência.

Network-bound: Com o surgimento da Internet, das plataformas paralelas distribuídas e da programação concorrente, muitas aplicações passaram a realizar comunicação em rede de maneira intensa, sendo denominadas de network-bound ou communication-intensive ou ainda communication-bound.

As aplicações podem pertencer a uma ou mais classes, uma vez que elas não são mutuamente exclusivas. Assim, é possível que uma aplicação seja $C P U$-bound e memory-

intensive ao mesmo tempo. É possível também que as tarefas alterem sua classificação durante sua execução, desta forma, uma aplicação pode ser classificada como networkbound no momento de sua submissão e mudar seu comportamento durante a execução, sendo classificada como I/O-bound, por exemplo. [5].

\subsection{Uso de informações no escalonamento}

A eficiência de um algoritmo de escalonamento depende da qualidade das informações disponibilizadas no momento da atribuição dos processos aos processadores [14].

Vários algoritmos de escalonamento, com o mesmo objetivo, podem apresentar desempenhos diferentes nas mais variadas combinações de hardware e software. De acordo com [8], alguns fatores que contribuem para esse cenário são: 
1. Plataforma computacional;

2. Algoritmo de escalonamento;

3. Classes das aplicações.

As arquiteturas influenciam diretamente no escalonamento, uma vez que pode existir heterogeneidade tanto arquitetural como configuracional entre as máquinas que compõem o ambiente, destacando a organização da memória, da rede de comunicação, do ambiente de troca de mensagens, entre outros fatores.

A influência dos algoritmos de escalonamento está ligada à forma com que foram implementados, pois os métodos gastam tempo analisando as informações. Dessa forma, deve-se avaliar a eficácia e a estabilidade das diversas implementações propostas, pois um algoritmo mal elaborado pode realizar computações inúteis, aumentando ainda mais a demanda por recursos, degradando o sistema [24].

Alguns trabalhos confirmam que algoritmos que consideram a classe da aplicação no momento do escalonamento, produzem melhores resultados se comparados aos que não classificam, visto que muitas vezes não é viável obter todas as informações possíveis, analisando todos os recursos disponíveis para escalonar um processo. Assim, a classificação das aplicações restringe esse "universo" de recursos, facilitando a análise [14].

No geral, o escalonamento dinâmico utiliza quantidades reduzidas de informações, pois o escalonamento é realizado no momento em que as tarefas chegam ao sistema, ou quando um nó da plataforma se torna sobrecarregado. Essa situação não se faz presente na categoria estática, onde as decisões são tomadas antes da execução, para um conjunto fixo de máquinas e aplicações, o que possibilita um gasto maior de tempo, analisando várias combinações feitas com as informações disponíveis, tentando encontrar uma solução quase ótima [5].

$\mathrm{Na}$ atividade de atribuição de processos a processadores, podem-se utilizar informações obtidas em execuções passadas para melhorar o desempenho da plataforma em futuras execuções com tarefas semelhantes. Isso é feito através de realimentações proporcionadas pelas próprias aplicações e através de obervações do comportamento da plataforma [27].

\subsection{Escalonamento de aplicações memory-intensive}

Estudos mais antigos [28], afirmaram que considerar informações referentes à memória em cada nó, como índice de balanceamento de carga, não traz ganhos quando comparados aos índices baseados em CPU. Isto ocorreu pois a carga de trabalho utilizada não apresentava um extenso conjunto de dados a ser manipulado, que caracteriza as aplicações 
memory-intensive. Outro fator predominante para esse resultado foi a baixa velocidade dos processadores da época, se comparados aos atuais.

Baseado nesse cenário, novos estudos foram realizados [21], comprovando que considerar informações sobre a memória pode apresentar ganho de desempenho. Nesse trabalho, os autores afirmam haver um "conflito de interesses" quando se realiza a alocação de processos em sistemas paralelos distribuídos, analisando o processador e a memória principal. Nesse conflito, o número de processadores alocados para as tarefas tende à diminuir na medida em que a carga do sistema aumenta. No entanto, a quantidade de memória requerida para formar o working set ${ }^{3}$ da aplicação, aumenta à medida que diminui a quantidade de processadores alocados a ele. Assim, se for alocada uma quantidade menor de processadores que um determinado limiar $\epsilon$, muitas ausências de páginas podem ocorrer, degradando o sistema.

Nas simulações realizadas nesse trabalho foi utilizado um sistema homogêneo com 64 processadores, todos com memória local. O esquema de escalonamento utilizado foi o particionamento variável, com partição fixa. Vários tamanhos de partições foram utilizados, variando de 1 até 64 processadores, sendo as partições múltiplos de dois. Ao chegar, uma tarefa recebe uma partição para executar, sem preempção, caso contrário aguarda em uma fila global.

Ao analisar os resultados apresentados na figura 4.2, observa-se que o tamanho ótimo da partição, ao considerar a carga da memória, não reduz bruscamente à medida que a carga no sistema aumenta, mantendo-se em trinta e dois processadores desde o momento em que a carga no sistema chegou a $30 \%$.

Ao contrário, ao desconsiderar a carga da memória, o tamanho da partição reduz abruptamente, chegando a indicar quatro processadores quando a carga no sistema atinge $90 \%$.

Esse comportamento, apresentado ao considerar informações de memória, garante o estabelecimento do working set das aplicações, aumentando o desempenho do sistema, como pode ser visualizado na figura 4.3.

No gráfico da figura 4.3 observa-se que a partição com trinta e dois processadores é superior as demais, para todas as porcentagens de utilização do sistema, concluindo, assim, que considerar informações de memória é importante para o cenário da computação atual.

Bons resultados, também, foram obtidos em [6] ao utilizar índices de memória no escalonamento. Nessa pesquisa, cujo objetivo central é a diminuição da ocorrência de ausências de páginas, dois ambientes foram propostos para realizar as simulações:

\footnotetext{
${ }^{3}$ Conjunto de páginas que um processo está atualmente usando [4]
} 


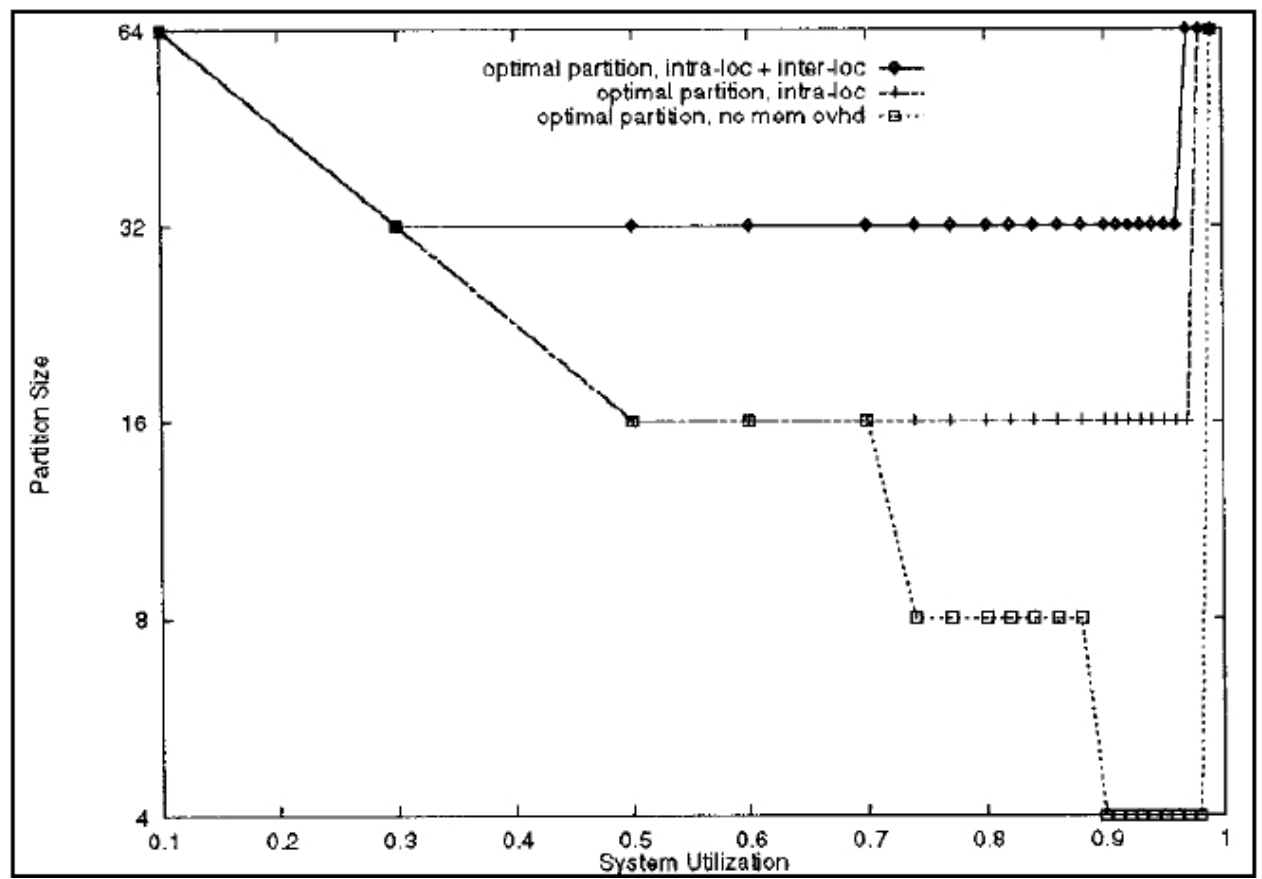

Figura 4.2: Tamanho ótimo da partição ao analisar, ou não, a ocupação da memória [21].

Ambiente 1: Neste ambiente a quantidade de memória necessária para a execução da tarefa é alocada na sua chegada, uma vez que a quantidade de memória requerida é conhecida no momento de sua submissão ao sistema. As aplicações possuem os working set estáveis durante a execução e são processadas em ambiente homogêneo. A migração de processos não é contemplada neste ambiente, que utiliza como carga de trabalho traces públicos ${ }^{4}$, considerando apenas a execução remota para balancear o cluster;

Ambiente 2: Esse ambiente também considera cluster homogêneo, porém, a quantidade de memória requerida pela tarefa é desconhecida, utilizando tanto execução remota, como migração de processos, para balancear a carga da plataforma.

Nesse cenário, os traces foram obtidos através de ferramentas disponíveis no sistema Linux $^{5}$ e também com instrumentação no kernel.

Para o primeiro ambiente foram propostas três políticas. A primeira baseada unicamente no tamanho da fila processos prontos ${ }^{6}$; assim, se a capacidade total da fila não foi atingida, a tarefa é executada localmente, caso contrário é executada remotamente na máquina com a menor fila. Algo semelhante ocorre na segunda política, que baseia-se unicamente na quantidade de memória livre; dessa forma, se o nó que recebeu a tarefa possuir memória disponível no espaço do usuário para alocar para a aplicação, ela é exe-

\footnotetext{
${ }^{4}$ Coletados pelo Los Alanos National Lab.

${ }^{5}$ Como os programas top, ps e free.

${ }^{6}$ Denominada deste ponto em diante apenas como fila de prontos.
} 


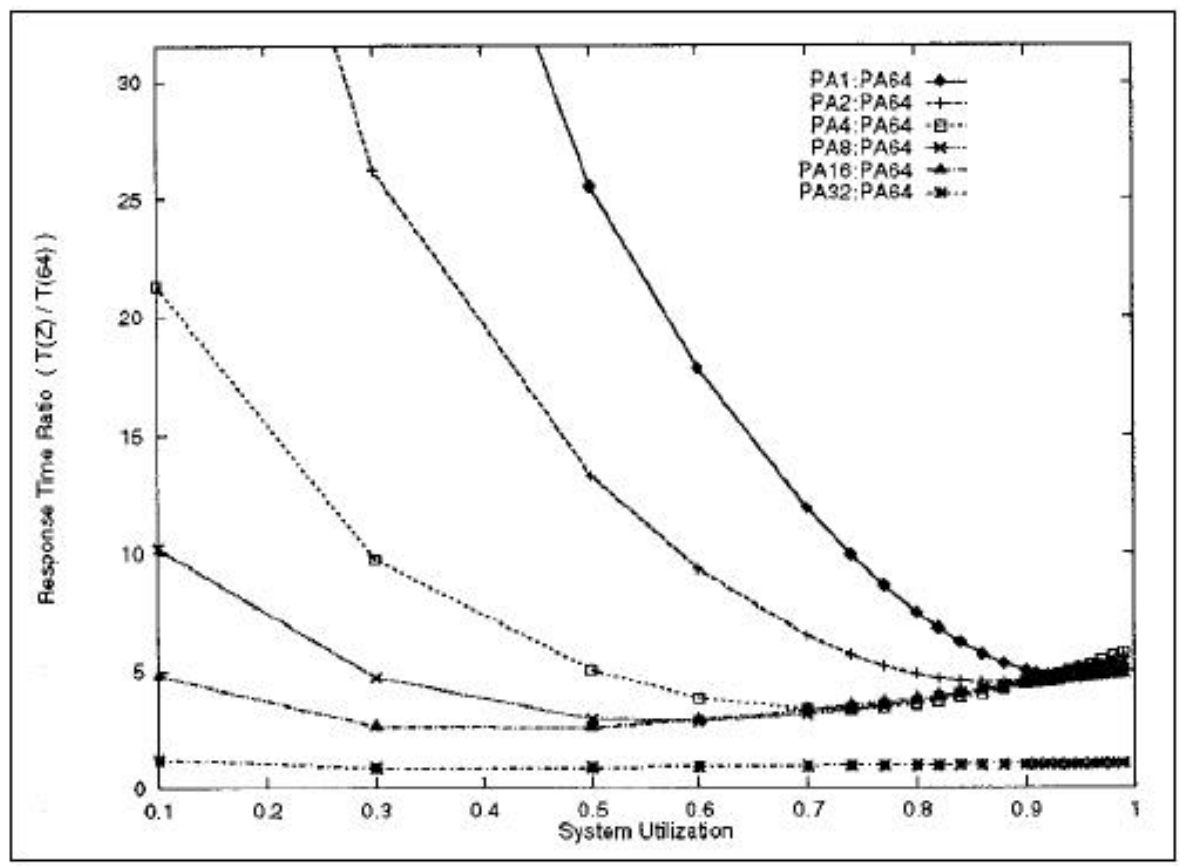

Figura 4.3: Tempo de resposta das aplicações utilizando diferentes tamanhos de partição $[21]$.

cutada localmente, caso contrario, é enviada para execução remota na máquina com a maior quantidade de memória disponível no espaço do usuário.

A terceira, e última política, é baseada na combinação das informações, fila de prontos e quantidade de memória livre no espaço do usuário, definindo um índice que se for menor que a capacidade máxima da fila de prontos, define que a tarefa será executada localmente, caso contrário, será enviada para execução remota no nó com a menor fila. Apesar de utilizar informações de memória, o índice é convertido para tamanho de fila de prontos.

Duas abordagens são utilizadas neste ambiente para definir o índice da terceira política. Na primeira o desempenho é priorizado, já na segunda prioriza-se a vazão, visando a balancear a utilização dos recursos no cluster.

Nas simulações realizadas nesse primeiro ambiente, detectou-se que a política baseada em memória não apresentou bons resultados, pois não considera o balanço de carga. Assim, tende a acumular processos em máquinas com memória livre, gerando ausências de páginas sempre que uma nova tarefa é submetida. O mesmo ocorreu com a política baseada na fila do processador, uma vez que várias tarefas com pequena quantidade de memória ocuparam os processadores executando em tempo compartilhado. A terceira política, porém, apresentou bons resultados, sendo significativamente superior às duas anteriores. Ambas as abordagens, desempenho e vazão, são semelhantes, porém, a primeira comportou-se melhor em situações de carga elevada.

No segundo ambiente, a decisão de aceitar, ou não, uma tarefa para execução, é 
realizada através do monitoramento da memória DRAM. Desta forma, três situações são possíveis:

1. Sobrecarga na RAM $<0$;

2. Sobrecarga na $\mathrm{RAM}=0$;

3. Sobrecarga na RAM $>0$.

Na primeira situação, a memória principal não será totalmente ocupada por processos, o que pode ocorrer na segunda situação. Entretanto, a utilização do espaço de swap somente é permitida na terceira configuração.

Essas abordagens são utilizadas também para escolher qual máquina receberá a tarefa a ser migrada. Assim, faz-se necessário definir políticas que selecionem qual tarefa será migrada. Definiram-se, então, quatro políticas para realizar esse objetivo:

pf-rate: Seleciona a tarefa com o maior número de ausências de páginas geradas;

worksize: Escolhe a tarefa com maior working set;

age: Migra a tarefa mais "velha", ou seja, aquela que está há mais tempo no sistema;

combined: Seleciona a tarefa com maior atividade de CPU, memória e I/O.

Os piores resultados foram apresentados pelos algoritmos pf-rate e age. O algoritmo worksize apresentou-se estável e próximo dos resultados obtidos pelo combined, que foi superior em todas as simulações.

Esses resultados reforçam aqueles obtidos pelo trabalho citado anteriormente [21], porém acrescenta que índices baseados em processadores devem ser utilizados para balancear a carga, já que aplicações memory-intensive são consideradas também $C P U$-bound na maioria dos casos.

A maioria dos trabalhos encontrados na literatura possuem métodos próprios para comparar índices de recursos heterogêneos, no entanto, o trabalho apresentado por [29] demonstra a unificação de índices heterogêneos através do algoritmo Assign-u, convertendoos para um custo homogêneo e independente de recursos.

Esse algoritmo analisa somente a carga presente na plataforma, não mantendo relação com o passado ou futuro. Assim, quando uma tarefa é submetida a um nó, realiza-se o cálculo de custo para executar essa tarefa em cada nó, atribuindo-o à máquina que gerar o menor custo, reduzindo, sempre que possível, o custo do cluster. O mesmo ocorre quando uma tarefa é finalizada e novos cálculos são executados para balancear o custo total da plataforma. 
Esta solução também pode ser utilizada em sistemas heterogêneos, já que converte a ocupação dos recursos em índices percentuais, independentemente da plataforma.

Os autores realizaram experimentos modificando os códigos do PVM, que atribui processos através do algoritmo Round-Robin, e do Mosix que procura manter no sistema sempre a maior quantidade de memória principal livre. As modificações foram chamadas de E-PVM e E-Mosix, respectivamente.

Ambas as modificações apresentaram-se superiores às implementações originais, mostrando que o algoritmo Assign-u, modicado pelos autores, é competitivo.

Outros trabalhos que utilizam a memória para melhorar o desempenho do sistema são encontrados na literatura, tal como apresentado em [30], que melhora o desempenho do sistema colhendo memória inativa em um sistema distribuído. No artigo [31], os autores migram a melhor tarefa, de acordo com a política de seleção utilizada, executando em um nó congestionado, para a máquina remota com a maior quantidade de memória livre. Em [13], é proposta uma nova solução ponto-a-ponto, denominada Parallel Network RAM, que procura diminuir a sobrecarga causada pela sincronização e comunicação das aplicações paralelas, evitando o uso do disco rígido, e otimizando a utilização da memória DRAM, demonstrando que o uso de esquemas diferenciados é apropriado para situações diferentes.

Em [32] é proposta uma nova política baseada em pesos atribuídos dinamicamente aos servidores, de acordo com a ocupação dos recursos de CPU, memória e rede. Nesse trabalho é abordado o escalonamento centralizado, cujo objetivo é balancear as conexões estabelecidas com o sistema, permitindo a melhor utilização dos recursos dos servidores, levando a um ganho de desempenho, se comparado à política Weighted Least Connection (WLC), descrita também em [32], que foi utilizada como base para a definição da nova política, porém obtendo estados imprecisos dos servidores.

Novos cenários também têm sido estudados, como o proposto em [33], que realiza o balanceamento de carga em um sistema de interligação de clusters heterogêneos, apresentando heterogeneidade tanto de CPU, quanto de memória. Esse trabalho propõe a política Local Cluster First (LCF) para realizar o escalonamento entre os clusters do sistema, aplicando as políticas definidas em [34] e [6] para realizar o balanceamento de carga entre os nós de um cluster.

Porém, a busca por nós com pouca carga é limitada inicialmente ao cluster local. Dessa forma, a busca por computadores em um cluster remoto somente será liberada caso nenhum nó do cluster local possa receber o processo. 


\section{5 Índices de carga baseados em memória}

Através dos trabalhos destacados anteriormente, percebe-se a importância de estudar novas políticas de escalonamento, destinadas às aplicações caracterizadas pela utilização de memória, uma vez que nos equipamentos modernos a CPU apresenta uma velocidade muito maior que as memórias, tornando estas um "gargalo" nos sistemas.

Baseado nesse raciocínio, novos índices de memória foram buscados em [5], utilizando o sistema operacional Linux, uma vez que este é muito utilizado tanto em trabalhos acadêmicos, como em ambientes corporativos, por ser de código aberto e apresentar os recursos de um sistema moderno.

Foram relatados em [5] onze índices, que foram agrupados de acordo com as características das informações fornecidas. Os grupos estabelecidos foram:

- Atividade do processador;

- Utilização da memória;

- Utilização do espaço de swap;

- Atividade da memória virtual;

- Ausências de páginas.

Esses índices foram selecionados por serem facilmente obtidos no sistema operacional Linux, no nível de usuário, e sem a necessidade de modificações no kernel, devendo refletir direta ou indiretamente informações sobre a utilização ou a atividade da memória [5].

Esses índices serão relatados neste capítulo, juntamente com as métricas definidas. Porém, a ordem demonstrada neste trabalho não será a mesma utilizada pelo autor da dissertação. Essa modificação tem como objetivo melhorar o entendimento dos índices, embora, a nomenclatura utilizada aqui será a mesma utilizada em [5].

\subsubsection{Pseudo-sistema de arquivos /proc}

Os índices propostos em [5], foram retirados do pseudo-sistema de arquivos / proc, pois, é através dele que ferramentas como top, ps e free coletam informações para exibí-las aos usuários. Essas ferramentas apresentam resultados compatíveis com os obtidos em instrumentação no kernel do sistema operacional, constituindo as duas maneiras possíveis de realizar essa atividade [6]. A principal vantagem em utilizar o /proc, e não a instrumentação, é a obtenção de informações do kernel de maneira organizada e no nível de usuário, 
já que ele implementa uma interface entre o usuário e as estruturas do núcleo do Linux [5].

O / proc é tratado como um pseudo-sistema de arquivos, pois, embora seu conteúdo esteja armazenado em memória principal, seus arquivos são acessados da mesma maneira que os arquivos armazenados em disco.

Encontra-se nesse diretório um subdiretório para cada processo em execução, juntamente com outros destinados a manter e fornecer informações sobre o sistema como um todo. Os índices definidos em [5] foram retirados de arquivos pertencentes ao segundo grupo:

stat: Esse arquivo armazena informações sobre o status do sistema, destacando informações sobre o uso do processador. Um exemplo do conteúdo pode ser observado na figura 4.4, onde algumas linhas que não serão necessárias no contexto deste trabalho foram suprimidas, pois o arquivo possui muitas informações, tornando desnecessário exibi-las.

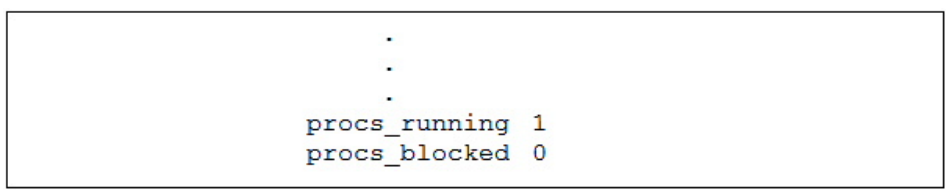

Figura 4.4: Arquivo/proc/stat.

meminfo: Contém informações sobre o estado atual tanto da memória principal, como da secundária (espaço de swap). Na figura 4.5 pode ser visualizado seu conteúdo.

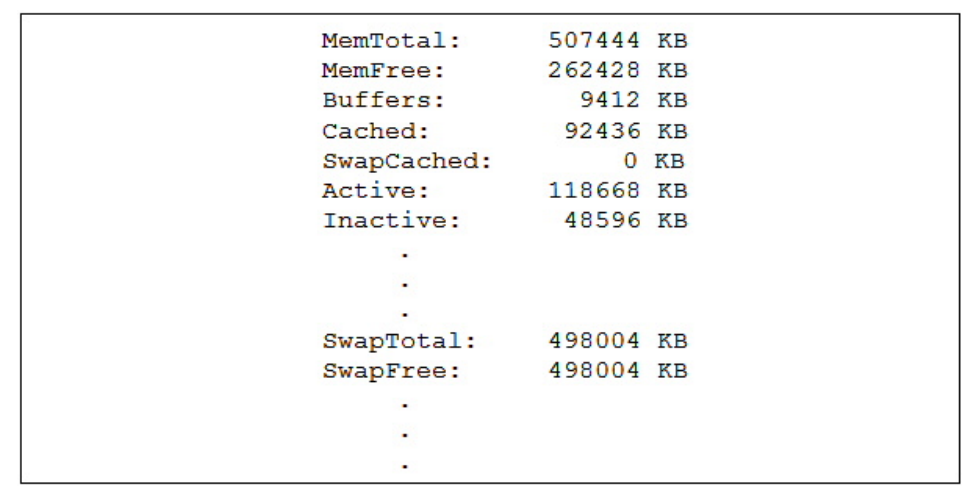

Figura 4.5: Arquivo/proc/meminfo.

vmstat: Reporta informações sobre processos, memória, sistema de paginação, bloqueios de E/S, traps e atividade de CPU. As informações disponibilizadas são médias desde a última reinicialização do equipamento. Um exemplo do conteúdo deste arquivo pode ser verificado na figura 4.6. 


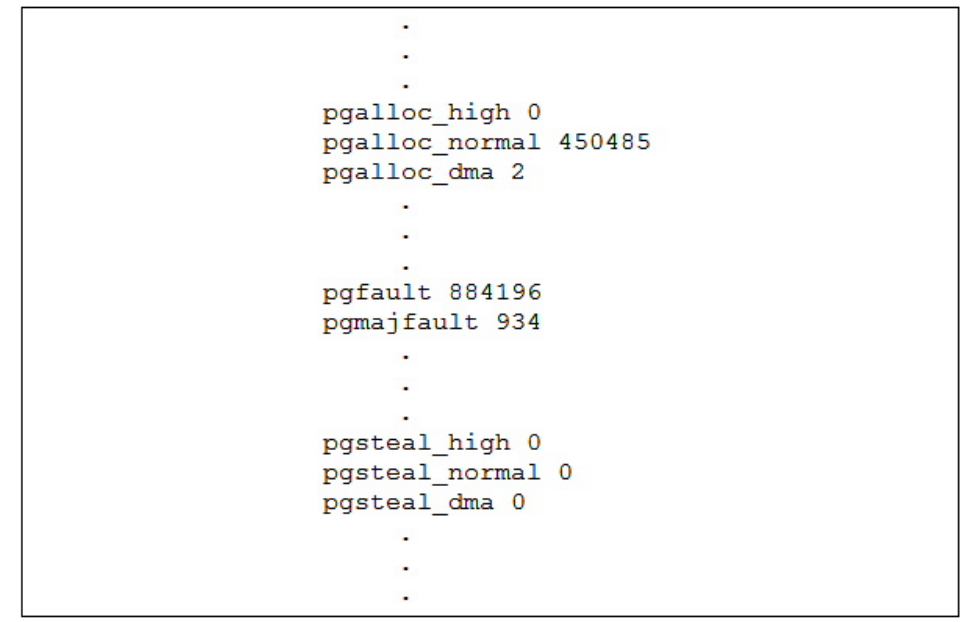

Figura 4.6: Arquivo /proc/mvstat.

\subsubsection{Metodologia}

Para demonstrar o comportamento dos índices de carga baseados em memória, foram realizadas, em [5], simulações com programas considerados na literatura como memoryintensive. Foram utilizadas as aplicações BRAMS, GAMESS e PHOLD [5]. Realizaram-se sete experimentos com quatro limites distintos de ocupação máxima de memória DRAM, conforme tabela 4.1. Para cada simulação foram submetidas doze configurações diferentes das aplicações, em intervalos predefinidos de sessenta segundos.

\begin{tabular}{|c|c|c|}
\hline Iteração & Percentual de utilização & Memória permitida \\
\hline $1^{a}$ & $50 \%$ & $256 \mathrm{MB}$ \\
\hline $2^{a}$ & $80 \%$ & $410 \mathrm{MB}$ \\
\hline $3^{a}$ & $110 \%$ & $563 \mathrm{MB}$ \\
\hline $4^{a}$ & $150 \%$ & $768 \mathrm{MB}$ \\
\hline $5^{a}$ & $110 \%$ & $563 \mathrm{MB}$ \\
\hline $6^{a}$ & $80 \%$ & $410 \mathrm{MB}$ \\
\hline $7^{a}$ & $50 \%$ & $256 \mathrm{MB}$ \\
\hline
\end{tabular}

Tabela 4.1: Váriações de carga usadas no monitoramento [5]

A máquina utilizada possuía 512 MB de memória DRAM e, dessa forma, ao estipular um limite de $150 \%$ de ocupação, espera-se que toda a memória DRAM seja ocupada e ainda $256 \mathrm{MB}$ de espaço de swap. Esses limites não indicam que as aplicações não ultrapassaram a quantidade máxima de memória estipulada, pois, durante a submissão a quantidade de memória necessária é desconhecida, mas, garantem que novas aplicações somente serão submetidas enquanto esses limites não forem ultrapassados. Caso alguma aplicação não possa ser submetida, aguarda-se um intervalo de sessenta segundos e realizase uma nova análise, caso o limite não tenha sido ultrapassado, a tarefa será submetida, 
caso contrário aguardará por mais sessenta segundos e assim sucessivamente.

\subsubsection{Utilização da memória}

Nessa categoria encontram-se os índices e métricas que relatam a situação da memória principal gerenciada pelo sistema operacional. Essas informações são obtidas através do arquivo meminfo, do pseudo-sistema de arquivos / proc.

O índice 2 define a quantidade de memória DRAM utilizada pelas aplicações. Essa informação não é disponibilizada pelo Linux, porém, o mesmo reporta a quantidade total de memória no sistema para as aplicações, retirando a memória utilizada pelo kernel, e a quantidade de memória livre. Essas informações podem ser coletadas pelos itens MemTotal e MemFree, respectivamente. Bastando apenas subtrair essas duas entradas do arquivo meminfo para obter a quantidade de memória principal ocupada. O comportamento desse índice pode ser visualizado na figura 4.7

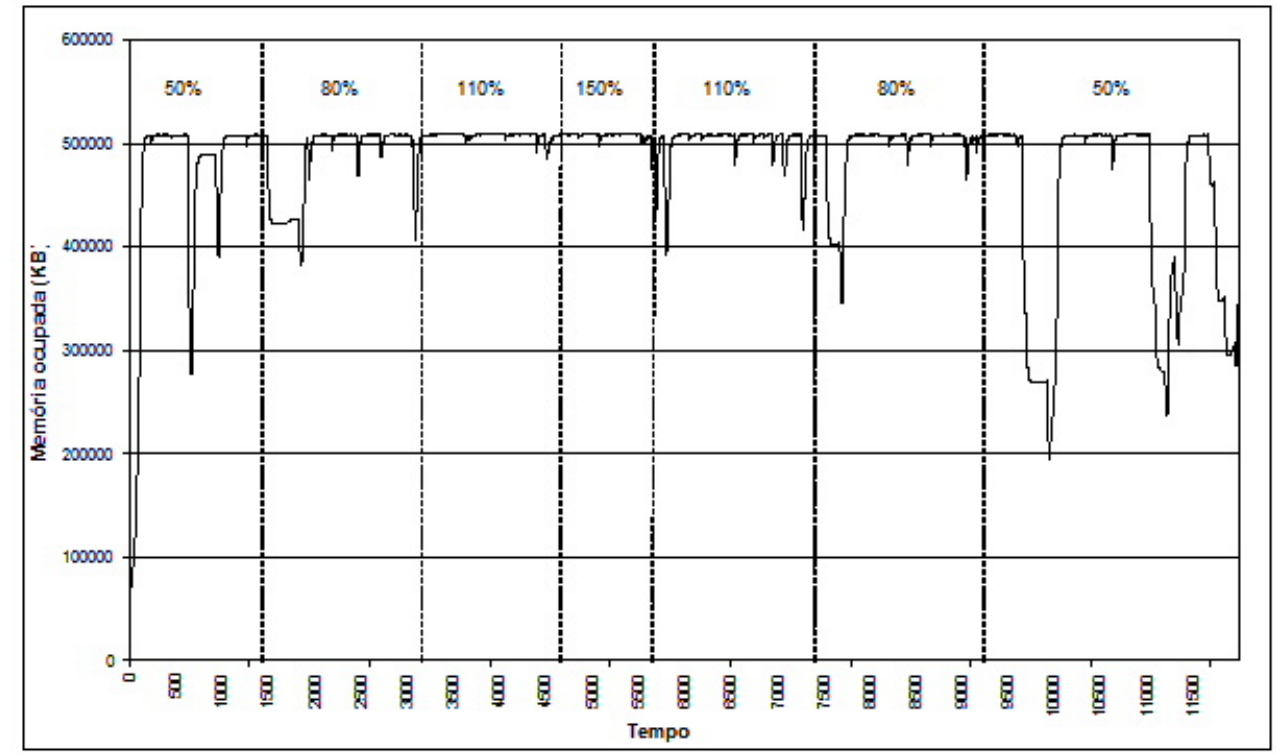

Figura 4.7: Comportamento do índice 2 [5].

Apesar do sistema possuir carga de trabalho variável durante a simulação, percebemse que os valores indicados pelo índice 2 permanecem próximos à ocupação de $100 \%$ da memória principal, não fornecendo a real ocupação da memória. Esse efeito ocorre porque o sistema operacional Linux mantém os dados de cache e buffer na memória principal, mesmo que não estejam sendo utilizados pelas aplicações [5].

Quando uma página deve ser enviada para o espaço de swap, uma cópia é mantida na memória principal, pois ela pode ser novamente acessada, não sendo necessário, assim, ser buscada na mídia externa de armazenamento, essa tarefa é denominada de cache de 
páginas.

O buffer é utilizado nas operações de leitura e escrita em disco. Na leitura, uma quantidade de informações maior que a solicitada é enviada para o sistema operacional e armazenadas no espaço de buffer, uma vez que, de acordo com o princípio da localidade espacial, existe uma grande probabilidade desses dados serem também solicitados pela aplicação [35]. Na operação de escrita, o Linux acumula dados a serem gravados, enviandoos em intervalos de tempos predefinidos para o disco, gastando menos tempo com essa operação e tornando-a mais eficiente [5].

A partir dessa informação foi definido o índice 3, memória utilizada em cache e buffer, que pode ser obtido através da soma dos itens Buffers e Cached do arquivo meminfo. Na figura 4.8 , pode ser visualizado o comportamento desse índice.

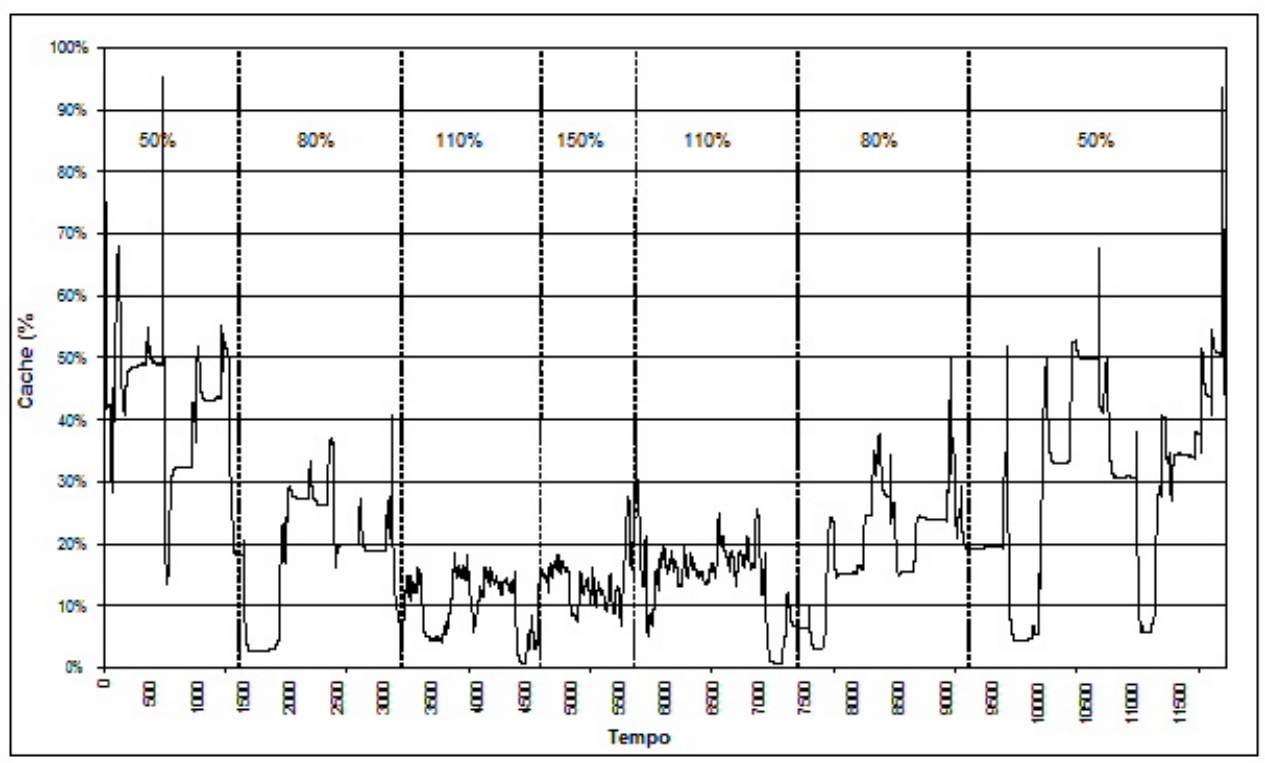

Figura 4.8: Comportamento do índice 3 [5].

Analisando-se o gráfico da figura 4.8, observa-se que a quantidade de memória direcionada ao cache e buffer é inversamente proporcional à carga no sistema. Isso pode ser observado pela queda da porcentagem de memória ocupada entre os intervalos um e quatro, com $50 \%$ e $150 \%$ de ocupação, respectivamente.

Surge, dessa forma, a métrica 1, que indica a quantidade de memória ocupada (índice 2), retirando o espaço ocupado pelas dados de caches e buffers (índice 3). A figura 4.9 apresenta uma comparação dos valores obtidos com a métrica 1 e com o índice 2.

A métrica 1 apresenta o comportamento esperado, variando de acordo com as interações, o que não ocorria com o índice 2. Nas interações três, quatro e cinco, a ocupação de memória não chega a ultrapassar o valor aproximado de $507 \mathrm{MB}^{7}$, porque os índices

\footnotetext{
${ }^{7}$ Memória disponível para as aplicações.
} 


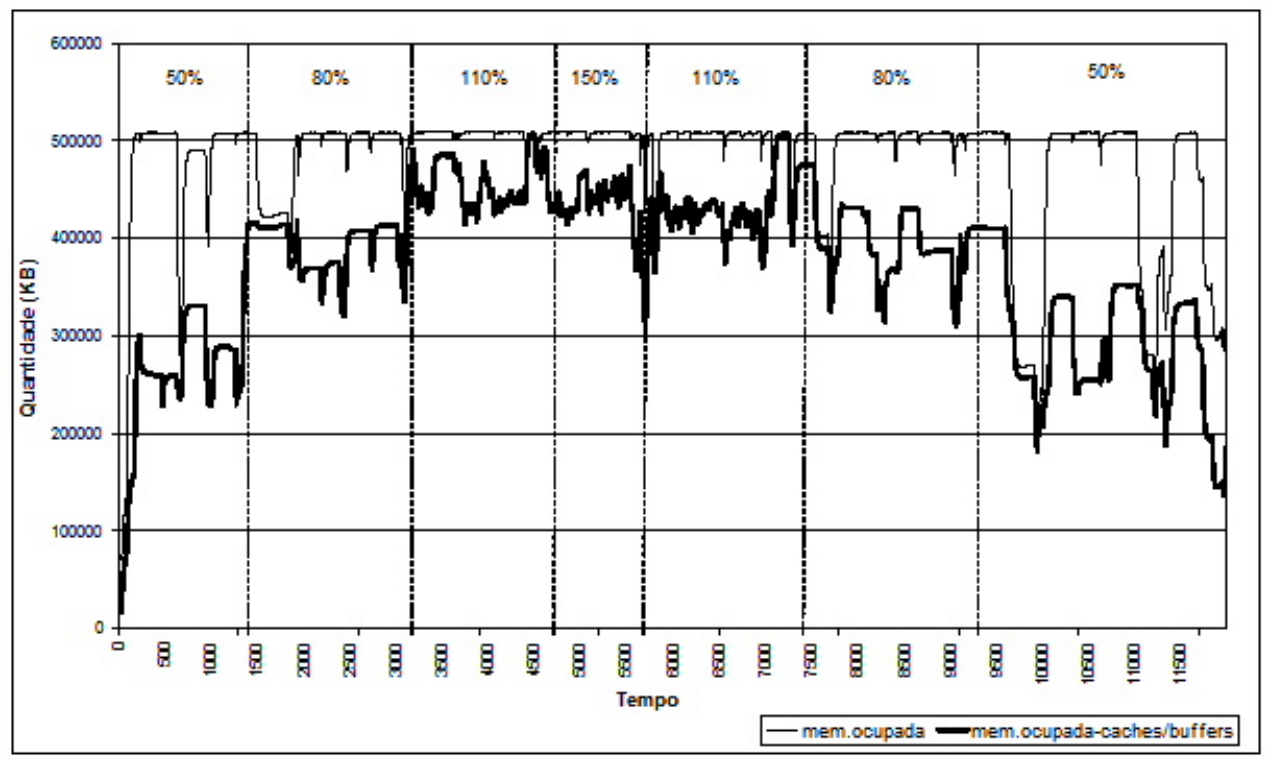

Figura 4.9: Comparativo métrica 1 versus índice 2 [5].

e métricas, discutidos até o momento, reportam apenas informações sobre a memória principal, não abordando o espaço de swap.

Apesar de mais realista que o índice 2, a métrica 1 apresenta falhas. No sistema Linux existem duas listas de páginas, as ativas e inativas. Na lista de ativas estão as molduras que não podem ser substituídas com outras páginas, uma vez que estão sendo utilizadas pelas aplicações. A lista de inativas, por sua vez, contém aquelas molduras que estão disponíveis para substituição de página, porém, ainda armazenam as páginas que podem ser desalocadas, porque elas podem novamente ser requisitadas, não necessitando serem lidas do disco novamente, caso, ainda estejam nas suas molduras. A essas duas informações foram dadas as denominações de índice 4 e índice 5 , respectivamente, podendo ser obtidas a partir das entradas Active e Inactive.

As páginas armazenadas no espaço de cache e buffer, podem pertencer tanto às páginas ativas, como inativas. Assim, considerar todo o espaço destinado a essas estruturas como memória livre não está totalmente correto, pois os dados armazenados podem pertencer a páginas ativas, que não serão substituídas [5].

O Linux sempre aloca páginas às aplicações a partir das molduras inativas; com isso, torna-se mais prudente obter a quantidade "real" de memória ocupada subtraindo-se o índice 2 do espaço ocupado com as páginas inativas, índice 5 , dando origem à métrica 2. A figura 4.10 apresenta um comparativo entre as métricas 1 e 2.

Através da análise do gráfico percebe-se que, apesar de semelhantes, a métrica 1 apresenta valores diferentes da métrica 2, chegando a diferenças em torno de $15,84 \%^{8}$,

\footnotetext{
${ }^{8}$ De acordo com estatísticas presentes em [5].
} 


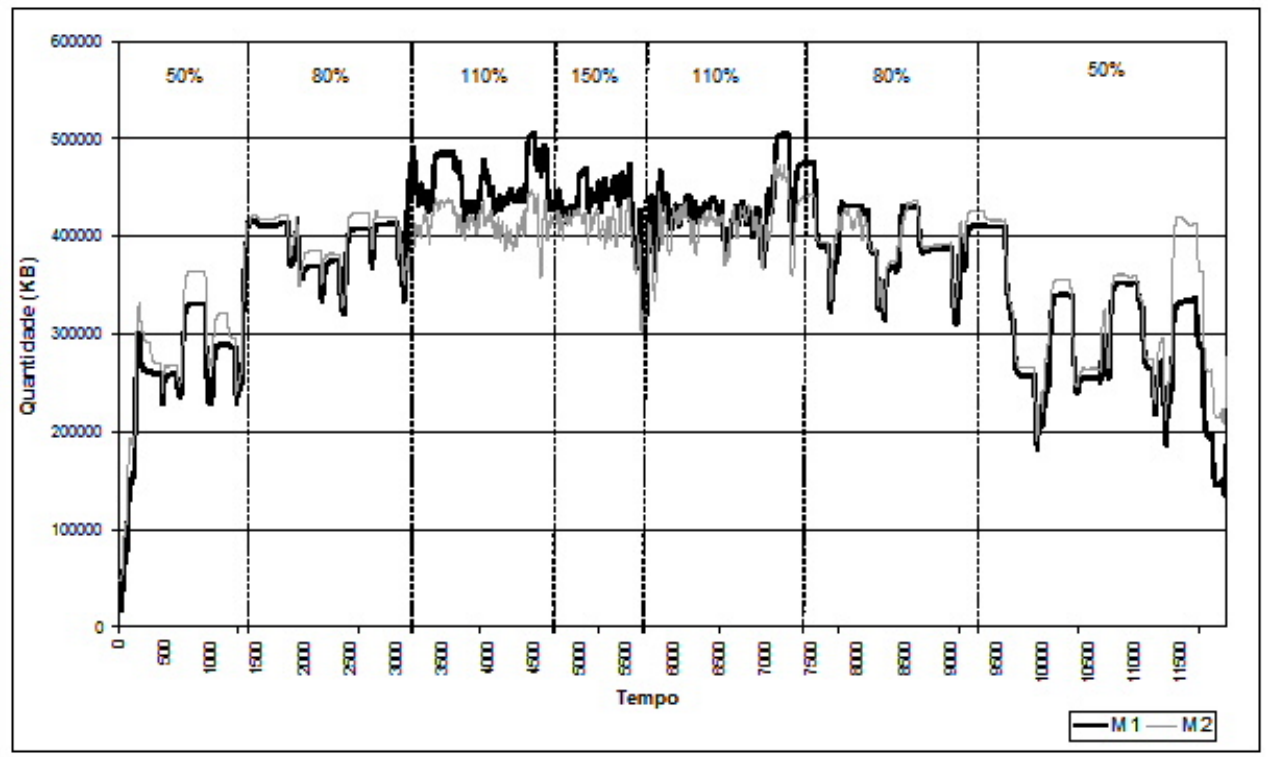

Figura 4.10: Comparativo métrica 1 versus métrica 2 [5].

apresentando informações distorcidas da memória realmente ocupada, o que pode levar a decisões incorretas no escalonamento.

O Linux possui a primitiva de manter uma relação de dois para um, entre a quantidade de páginas ativas e inativas. Assim, para cada duas páginas ativas deve haver uma inativa. No entanto, essa relação muitas vezes não pode ser mantida, devido à saturação da memória principal ou até mesmo da grande quantidade de páginas alocadas em um curto espaço de tempo, por exemplo, quando uma aplicação é iniciada.

Quando ocorre uma grande quantidade de alocações, mas ainda há memória disponível no sistema, essa relação volta a ser estabelecida rapidamente, já que o algoritmo de marcação de páginas como inativa é acionado com freqüência. Esse restabelecimento entre páginas ativas e inativas não ocorre quando existe uma grande demanda por memória principal e não há disponibilidade da mesma, sendo necessário o uso do espaço de swap, o que pode levar o sistema ao estado de thrashing.

Para evitar a saturação da memória principal, [5] propõe a métrica 3, que é a relação entre a quantidade de páginas ativas e inativas, conforme figura 4.11.

Nas iterações com carga baixa e moderada, $50 \%$ e $80 \%$, respectivamente, os valores obtidos com essa métrica ficaram muito próximos do ideal, variando entre 1,5 e 3. Nas iterações de sobrecarga, $110 \%$ e 150\%, os valores obtidos foram superiores a 4 . Assim, se essa métrica indicar valores próximos a dois, o sistema operacional não está entrando em thrashing, caso contrário ele poderá estar realizando pouca computação útil [5].

Com relação aos picos, deve-se considerar que o sistema operacional está tratando muitas ausências de páginas, no entanto, pode estar entrando em thrashing ou estabelecendo 


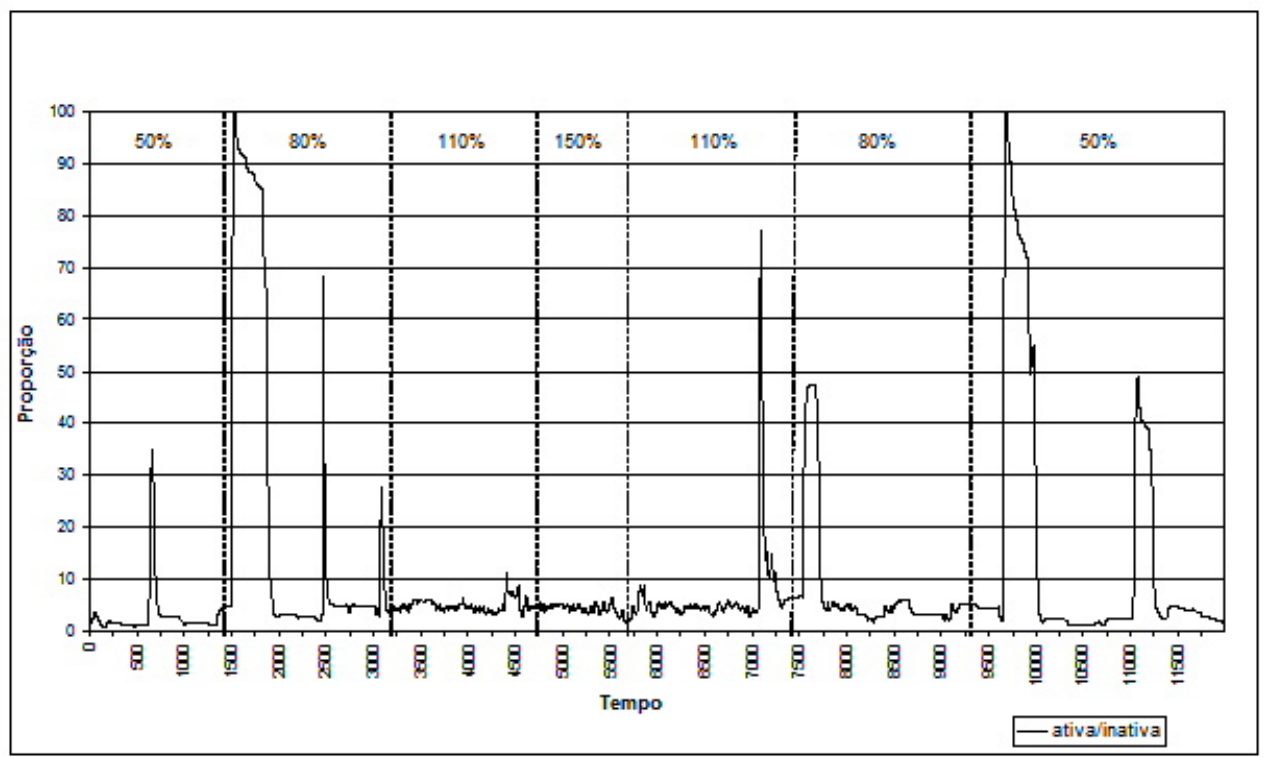

Figura 4.11: Comportamento da métrica 3 [5].

o working set de uma aplicação recentemente escalonada.

Dentre os índices e métricas citados, o índice 2 e a métrica 1 serão descartados, uma vez que não refletem os valores "reais" da quantidade de memória principal ocupada, que será representado nas políticas desenvolvidas neste trabalho pela métrica 2 .

O índice 3 será também descartado, pois apresenta o comportamento inverso do apresentado pela métrica 2, indicando indireta e parcialmente a ocupação de memória, em detrimento da indicação direta apresentado na métrica 2. Já os índices 4 e 5 também serão utilizados, podendo o índice 4 substituir a métrica 2 , já que, no sistema operacional Linux, apenas as páginas ativas são consideradas realmente ocupadas.

A adoção do índice 4, ao invés da métrica 2, pode apresentar vantagens com relação ao tempo gasto pela política de informação no momento de coletar e calcular os dados para as políticas de transferência e localização, já que a métrica 2 utiliza dois índices para ser obtida, o que não ocorre com o índice 4, que é obtido diretamente no arquivo meminfo, não necessitando de nenhum cálculo auxiliar.

O índice 5 também é facilmente obtido e será testado nas políticas desenvolvidas neste trabalho, representando informações opostas ao índice 4, uma vez que a quantidade total de memória disponível no sistema é igual à soma dos índice 4 e 5 . Assim, ao aumentar o valor de índice 4 , o índice 5 será diminuído na mesma proporção.

A métrica 3 também será descartada, pois, como observado na figura 4.11, os picos não apresentam um comportamento definido, não possibilitando identificar se estão ocorrendo muitas ausências de páginas no sistema ou se algum processo chegou ao nó para ser executado e está alocando suas páginas sob demanda. Até porque, através dos índices 4 e 
5 é possível obter esta distinção. Assim, a métrica 3 se torna redundante aos índices que a compõe, além de apresentar informações difíceis de serem análisadas durante a tomada de decisão do algoritmo de escalonamento.

\subsubsection{Atividade da memória virtual}

Com o objetivo de verificar a quantidade de páginas sendo alocadas por segundo, definiram-se os índices 8 e 9. O primeiro trata as páginas retiradas do espaço de cache e buffer (page stealing), podendo ser obtido pela soma dos itens pgsteal_high, pgsteal_normal e pgsteal_dma. O segundo referencia a quantidade de páginas alocadas por segundo, sendo obtido através da soma dos itens pgalloc_high, pgalloc_normal e pgalloc_dma. As entradas para os índices encontram-se no arquivo vmstat. Na figura 4.12 pode ser visualizado o comportamento desses índices.

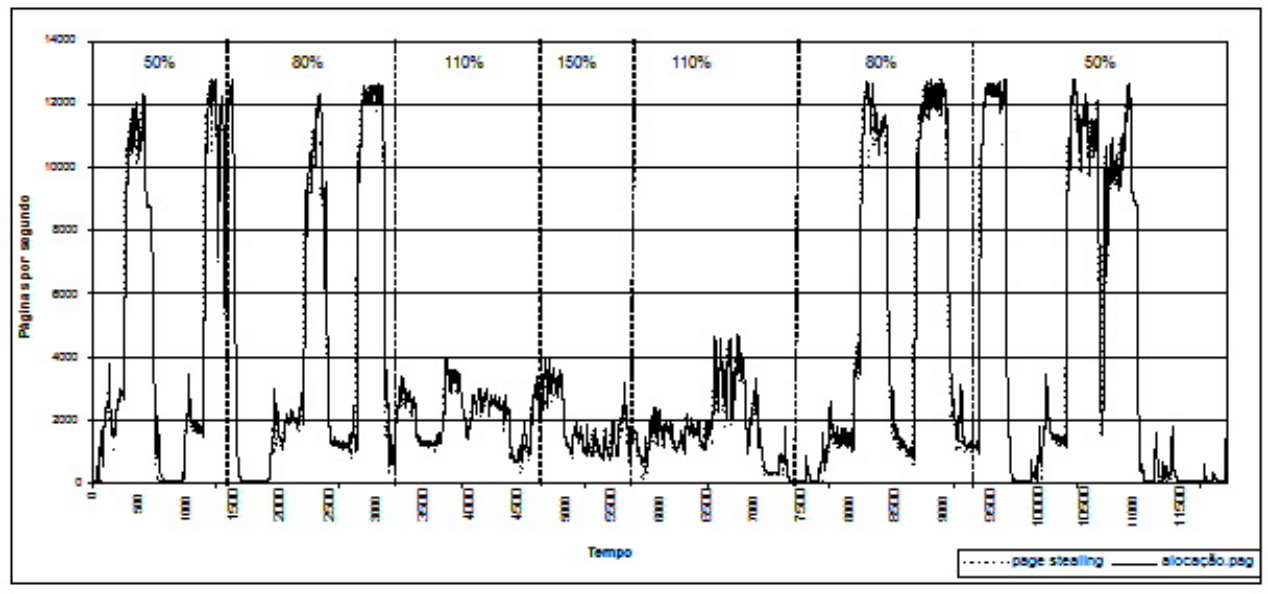

Figura 4.12: Comportamento dos índices 8 e 9 [5].

Ambos os índices apresentam comportamentos semelhantes, havendo necessidade de monitorar apenas um [5].

Nas iterações de sobrecarga percebe-se pouca atividade de alocação de páginas, o que não ocorre em momento de pouca carga. No entanto, nesse último cenário ocorrem oscilações que variam entre zero alocações e aproximadamente doze mil páginas por segundo ${ }^{9}$, além de possuir também valores semelhantes aos apresentados no primeiro cenário. Isso torna esse índice desfavorável às políticas de escalonamento, pois não é possível distinguir se a máquina está realmente sobrecarregada, pois, os valores encontrados não são exclusivos para uma determinada iteração. Desta forma, esses índices também não serão abordados nas políticas desenvolvidas neste trabalho.

\footnotetext{
${ }^{9}$ Este valor depende do equipamento utilizado [5].
} 


\subsubsection{Ausências de páginas}

Quando uma aplicação acessa sua tabela de páginas, endereços lógicos, para localizar um endereço físico de memória, é possível que esse mapeamento não esteja presente, gerando uma ausência de página que precisa ser tratada pelo núcleo do sistema operacional. Essa ausência de página pode ser de dois tipos:

Ausência menor: Não requer acesso à mídia de armazenamento externo. De acordo com [5], duas situações podem levar a esse acontecimento. Na primeira, ao carregar um processo, o Linux não preenche totalmente a tabela de endereços de páginas da aplicação; assim, ao tentar mapear um endereço, uma ausência de página ocorre, chaveando o contexto para o nível de núcleo. A rotina de tratamento de ausência de páginas do sistema operacional preenche o endereço na tabela do processo, devolvendo o controle para ele.

Na segunda, uma página pode ter sido marcada como inativa pelo daemon de paginação, essa página é novamente requisitada e ela não mais se encontra mapeada na tabela de endereços do processo, já que poderia ser substituída a qualquer momento; assim, a rotina do núcleo marca essa página como ativa e preenche novamente o endereço na tabela, liberando-a para a aplicação.

A ausência menor foi denominada índice $\mathbf{1 0}$ e pode ser quantificada através do arquivo vmstat, subtraindo os campos pgfault (total de ausências de páginas) e pgmajfault (total de ausências maiores), já que o pseudo-sistema de arquivos /proc não possui uma entrada específica para as ausências menores.

Ausência maior: Nessa categoria encontram-se as ausências que precisam ser tratadas com acesso ao disco, indicando que a página solicitada pela aplicação já havia sido enviada para a área de swap, precisando ser novamente lida da memória secundária, carregada em uma moldura disponível e remapeada na tabela de páginas do processo que gerou a ausência.

Essa categoria foi classificada como índice 11 e sua quantificação pode ser obtida diretamente do arquivo vmstat, na entrada pgmajfault.

O índice 10 pode ser utilizado para indicar a saturação da memória principal, já que a quantidade de ausências menores aumenta significativamente instantes antes do início da utilização do espaço de swap, que pode ser caracterizado pelo índice 11, já que as páginas registradas como ausências maiores são lidas do disco. A figura 4.13 apresenta um trecho do monitoramento desses índices, entre os instantes 2000 e 4000.

Esse intervalo de tempo encontra-se na transição da segunda para a terceira interação (instante 3100). Percebe-se que, instantes antes do início da utilização do espaço de swap 


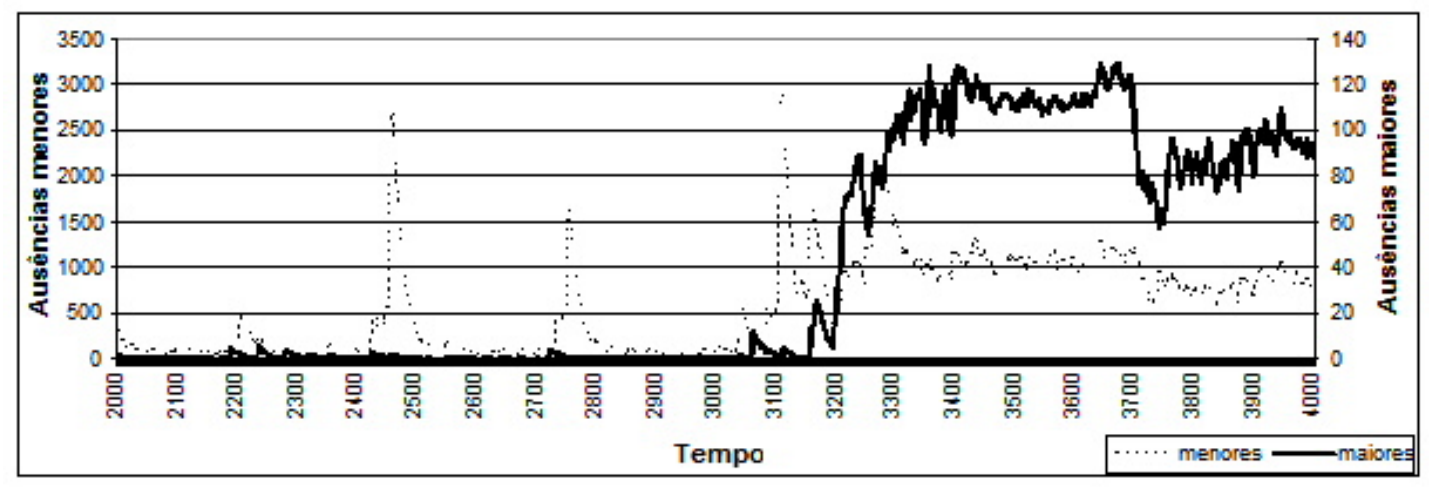

Figura 4.13: Comportamento dos índices 10 e 11 [5].

(instante 3200), o índice 10 apresenta uma grande variação, permanecendo com leituras elevadas durante o restante do monitoramento. Dessa forma, o autor sugere a utilização o índice 10 para acusar o saturamento da memória principal e o índice 11 para indicar a utilização do espaço de swap.

O índice 10 apresenta como desvantagem os picos que podem existir durante o monitoramento, picos estes que não indicam a saturação da memória principal, como ocorreu entre os intervalos 2400 e 2500. Assim, torna-se difícil através da leitura de apenas um pico indicar se a memória principal está saturada ou não, não atendendo ao requisito de estabilidade descrito em [23].

O índice 11, no entanto, é um bom indicador da atividade do espaço de swap, já que muitas ausências maiores de páginas indicam a falta de memória principal disponível. Porém, não deve ser utilizado para quantificar o espaço ocupado na área de troca do sistema operacional, havendo outros índices e métricas definidos para essa atividade.

Outro fator que deve ser levado em consideração ao utilizar o índice 11 nas políticas de escalonamento, é o fato do arquivo vmstat armazenar informações desse o momento de boot do sistema operacional. Assim, mesmo que uma máquina não esteja sofrendo ausências maiores de páginas, é possível que esse índice contenha um valor elevado, devido à saturação da memória principal ocorrida anteriormente. Portanto, é necessário que medidas sejam tomadas no momento do escalonamento para amenizar esse comportamento.

\subsubsection{Utilização do espaço de $\operatorname{swap}$}

O índice 6 indica a quantidade de espaço de swap utilizada pelo sistema operacional. Este valor pode ser obtido através da subtração das entradas SwapTotal e SwapFree, já que o Linux não armazena este valor como um único item no arquivo meminfo.

No sistema Linux, quando uma página é lida do espaço de swap e armazenada em 
uma moldura, sua cópia permanece no disco em forma de cache, denominado swap cache, evitando que seja necessária uma nova gravação, caso a página tenha que voltar para o disco e não tenha sofrido alterações. Dessa forma, o índice 6 continua indicando que o espaço de swap não sofreu alterações, mas, essa parte do cache pode ser utilizada a qualquer momento, devendo ser considerada como espaço livre.

No arquivo meminfo encontra-se a entrada SwapCached, que contabiliza as páginas que estão armazenadas como cache, sendo mais prudente considerar como espaço de swap ocupado a subtração do índice 6 e 7, o que dá origem à métrica 4 . O comportamento dessa métrica pode ser visualizado na figura 4.14 .

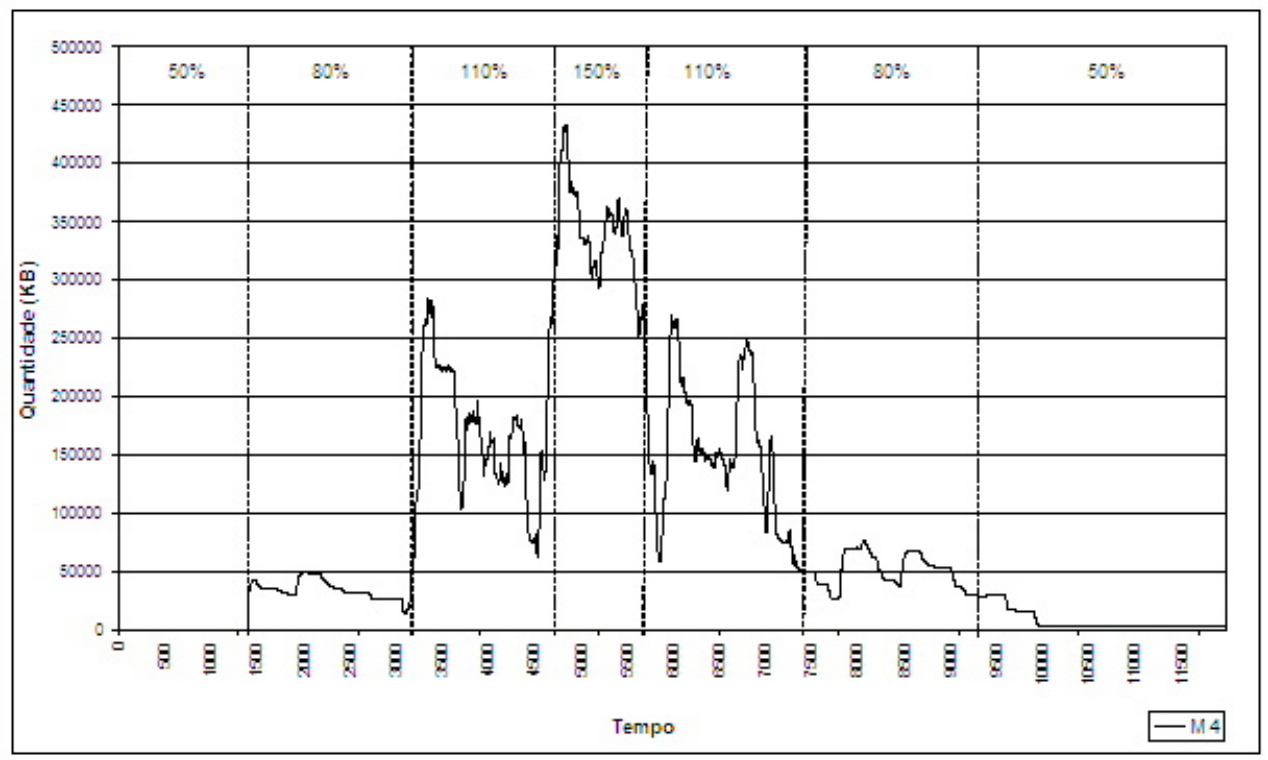

Figura 4.14: Comportamento da métrica 4 [5].

Os índices 6 e 7 apresentam o mesmos problemas encontrados nos índices 2 e 3 . Dessa forma, o índice 6 não representa o valor correto do swap utilizado e o índice 7 apresenta informações inversas ao apresentado pela métrica 4, o que torna os índices 6 e 7 desfavoráveis para serem utilizados nas políticas de escalonamento, cedendo lugar para a métrica 4 , que reflete diretamente a quantidade de swap utilizado.

\subsubsection{Atividade do processador}

A quantidade de processos bloqueados recebeu a denominação de índice 1, que pode ser obtido no arquivo stat, na entrada procs_blocked. No Linux, um processo pode receber o status bloqueado sempre que necessitar de uma operação de leitura e escrita em disco, ou acesso à rede de comunicação. Dessa forma, sempre que o sistema estiver entrando em estado de thrashing, uma grande quantidade de processos serão bloqueados devido à quantidade de páginas que precisam ser retiradas e enviadas para o espaço de swap. 
Processos entram em bloqueio mesmo que o sistema operacional não esteja em estado de thrashing, como pode ser observado nas iterações de carga baixa e moderada da figura 4.15, que retrata o comportamento do índice 1.

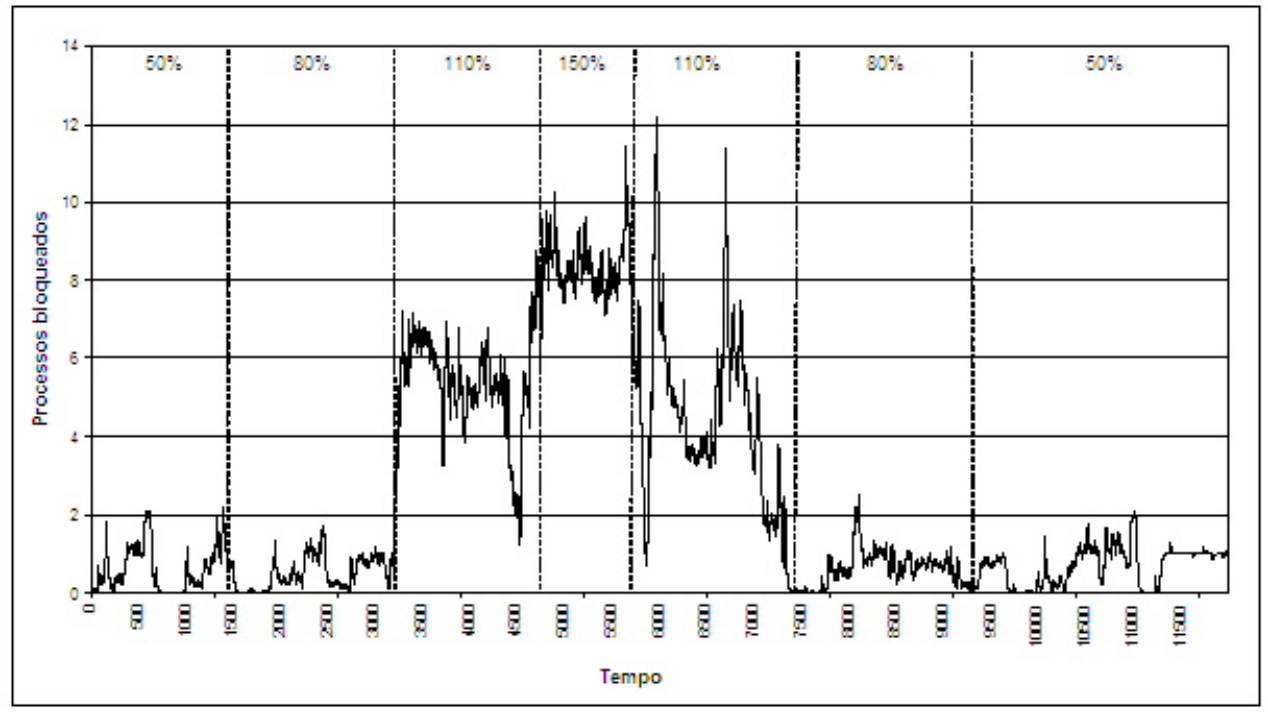

Figura 4.15: Comportamento do índice 1 [5].

Fica clara a necessidade de um outro índice que possa ser utilizado em comparação ao índice 1, permitindo informar se os processos estão sendo bloqueados por sobrecarga no sistema ou não.

Quando o sistema está entrando em thrashing, ele permanece a maior parte do tempo tratando ausências de páginas, dessa forma, a quantidade de processos em execução será muito menor que a quantidade de bloqueados [5]. Surge, dessa maneira, a métrica 5 que consiste na razão entre o índice 1 e a quantidade de processos em execução, que pode ser obtido também no arquivo stat, através da entrada procs_running.

A razão unitária é indicada por [5] como um bom referencial para identificar o estado de thrashing, uma vez que qualquer valor acima de um sinaliza mais processos bloqueados do que executando, caracterizando uma sobrecarga no sistema. Ao contrário, qualquer valor menor ou igual a um, desmonstra que o sistema está suportando a carga submetida [5]. A figura 4.16, apresenta o comportamento da métrica 5.

Pode ser observado que valores maiores que um ocorrem apenas nas iterações de sobrecarga do sistema, apresentando o pico na iteração quatro. No entanto, em alguns pontos em que o sistema operacional está sobrecarregado, o índice mostrou valores abaixo do unitário, como no instante 4500. Isso indica a necessidade de um estudo mais aprofundado dessa métrica, para obter um melhor ajuste no valor limite, pois, dependendo do momento do escalonamento, uma política pode interpretar que o sistema está com carga moderada, submetendo mais tarefas, o que sobrecarregaria ainda mais o sistema. 


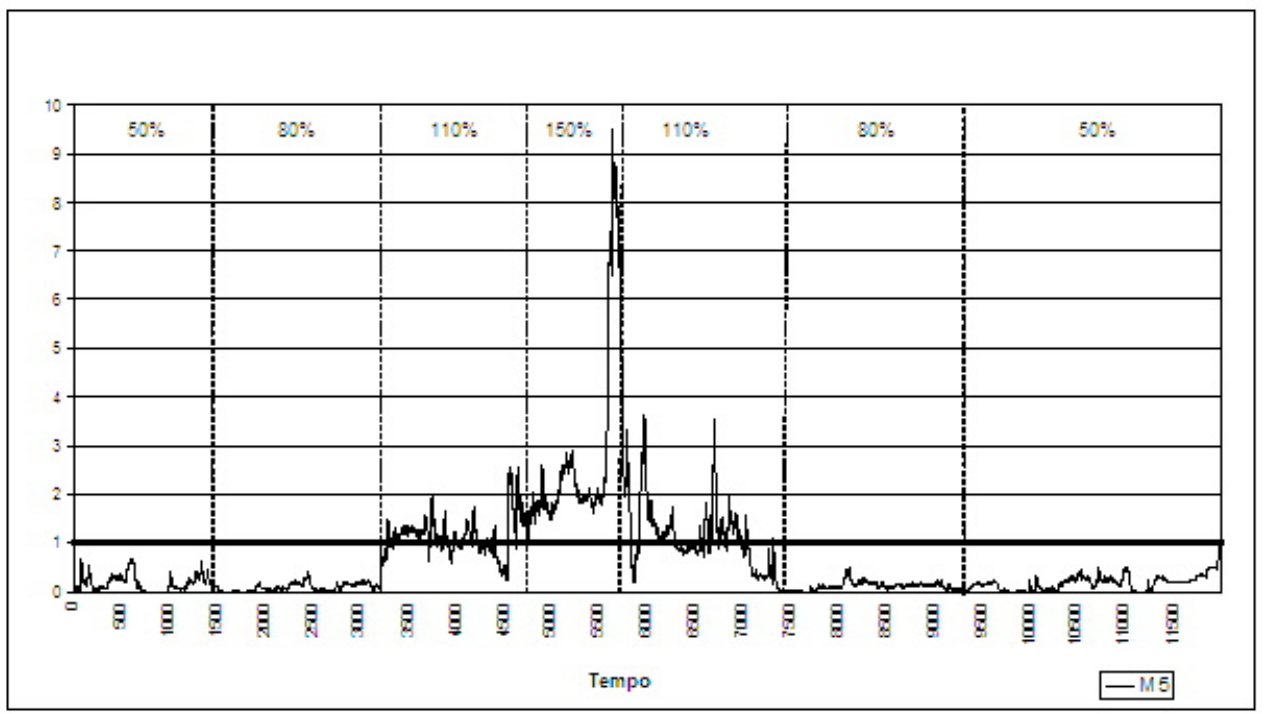

Figura 4.16: Comportamento da métrica 5 [5].

Neste trabalho também será utilizada a quantidade de processos executando, ou seja, aqueles que se encontram na fila de prontos da CPU, uma vez que é um dos índices mais utilizados na literatura para realizar o escalonamento baseado em CPU. Este índice demostrou ser muito útil e até mesmo indispensável nas políticas destinadas a escalonar aplicações memory-intensive, uma vez que estas são classificadas também como $C P U$ bound.

Na tabela 4.2 encontra-se um resumo dos índices e métricas descritos em [5], mostrando os que serão testados, ou não, na definição das políticas desenvolvidas neste trabalho.

\subsection{Considerações finais}

A classificação das aplicações é muito importante para a atividade de escalonamento, pois permite definir índices de carga adequados, bem como decidir o momento de escalonar. Assim, caso sejam submetidas aplicações em batch, pode-se optar pelo escalonamento estático, ao contrário das interativas, que exigem o escalonamento dinâmico.

O tipo de aplicação alvo deste trabalho são aquelas denominadas memory-intensive, que necessitam de índices baseados na utilização de memória para melhorar o desempenho do sistema. A partir dessa afirmação, alguns trabalhos definiram índices e políticas que refletem essa utilização.

Entre os trabalhos citados, encontra-se a dissertação de mestrado de Voorsluys [5], que define índices e métricas que refletem direta ou indiretamente o uso da memória. Alguns dos índices descritos também são encontrados em outras pesquisas, como em [6], porém, 


\begin{tabular}{|c|c|c|c|}
\hline Grupo & Identificação & Nome & Utilizar \\
\hline \multirow{2}{*}{$\begin{array}{l}\text { Atividade } \\
\text { processador }\end{array}$} & Índice 1 & Processos bloqueados & $\checkmark$ \\
\hline & Métrica 5 & Índice 1 / quant. proc. em execução & $\checkmark$ \\
\hline \multirow{7}{*}{$\begin{array}{c}\text { utilização } \\
\text { da } \\
\text { Memória Principal }\end{array}$} & Índice 2 & Memória Ocupada & $X$ \\
\hline & Índice 3 & Cache/buffer & $\mathrm{X}$ \\
\hline & Índice 4 & Memória ativa & $\checkmark$ \\
\hline & Índice 5 & Memória inativa & $\checkmark$ \\
\hline & Métrica 1 & Índice 2 - Índice 3 & $x$ \\
\hline & Métrica 2 & Índice 2 - Índice 5 & $\checkmark$ \\
\hline & Métrica 3 & Índice 4 / Índice 5 & $x$ \\
\hline \multirow{3}{*}{$\begin{array}{c}\text { Utilização } \\
\text { do } \\
\text { Swap }\end{array}$} & Índice 6 & Swap utilizado & $x$ \\
\hline & índice 7 & swap cache & $X$ \\
\hline & Métrica 4 & Índice 6 - Índice 7 & $\checkmark$ \\
\hline \multirow{2}{*}{$\begin{array}{c}\text { Atividade da } \\
\text { Memória Virtual }\end{array}$} & Índice 8 & Page stealling & $X$ \\
\hline & índice 9 & Páginas alocadas & $x$ \\
\hline \multirow{2}{*}{$\begin{array}{l}\text { Ausência } \\
\text { de Páginas }\end{array}$} & Índice 10 & Ausência memores & $x$ \\
\hline & Índice 11 & ausências maiores & $\checkmark$ \\
\hline
\end{tabular}

Tabela 4.2: Resumo dos índices definidos em [5]

são abordados, por [5], de uma nova perspectiva, já que podem ser obtidos no nível de usuário, sem intervenção do núcleo do sistema, através do pseudo-sistema de arquivos /proc.

Entre as métricas definidas, destaque deve ser dado à métrica 2, pois desconsidera as páginas inativas, na quantificação da memória DRAM ocupada, ao contrário das abordagens tradicionais, que excluem o espaço ocupado pelo cache/buffer, que podem conter páginas ativas e que não serão descartadas pelo sistema operacional.

A métrica 5, define uma relação entre a quantidade de processos bloqueados e aqueles em execução, permitindo retratar o estado do sistema como um todo.

A partir dos índices citados anteriormente, serão definidas novas políticas de escalonamento direcionadas às aplicações memory-intensive, que serão implementadas e avaliadas através de simulações. Sendo assim, faz-se necesário o desenvolvimento de um modelo e do simulador a ser utilizado, sendo estes tratados no próximo capítulo. 


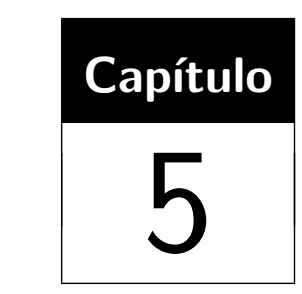

Modelos

\subsection{Considerações iniciais}

Para avaliar as políticas que serão propostas no capítulo 6, é necessário selecionar uma técnica de avaliação. De acordo com [11], essas técnicas dividem-se em duas categorias:

Aferição: Consiste em realizar experimentações no sistema, podendo ser através de construção de protótipos, benchmarks ou coleta de dados.

Modelagem: Consiste em criar abstrações do sistema a ser avaliado, gerando um modelo através de redes de filas, redes de Petri, statecharts entre outros.

A abordagem por coleta de dados, que constitui um tipo de aferição, poderia ser empregada para avaliar as políticas de escalonamento que foram desenvolvidas neste trabalho, no entanto, seria necessário implementá-las em um produto já existente como o openMosix, ou até mesmo criar um novo produto, semelhante a este, para realizar os experimentos. Assim, essa técnica foi rejeitada por varias razões, tais como:

1. Modificar o openMosix teria um custo de tempo elevado, dedicado ao entendimento da implementação do produto.

2. Seria necessário recompilar o programa e "carregar" os módulos, em cada máquina do cluster, toda vez que uma política fosse implementada ou modificada.

3. Utilizar o openMosix direcionaria o trabalho para o kernel 2.4.x, versão suportada pelo middleware, até o momento da escolha da técnica de avaliação. 
4. Esta abordagem limitaria os experimentos a uma implementação específica, podendo apresentar comportamento diferente em outro middleware, tal como o Open Single System Image (OpenSSI).

5. Desenvolver um novo middleware não faz parte dos objetivos deste trabalho.

Diante do exposto, conclui-se que utilizar coleta de dados, como técnica de avaliação, não apresenta vantagens sobre a modelagem para o contexto deste trabalho, mesmo oferecendo resultados mais precisos.

Dessa forma, adotou-se a técnica de modelagem por redes de filas, utilizando-se simulação para a obtenção da solução dos modelos gerados, uma vez que esta técnica é largamente utilizada, produzindo bons resultados. Assim, este capítulo apresenta a modelagem do sistema a ser estudado e apresenta o projeto do simulador a ser utilizado para avaliar as políticas propostas.

\subsection{Modelagem do sistema}

O modelo desenvolvido descreve um sistema de imagem única, onde o usuário não conhece a quantidade de máquinas que constitui o sistema e sua aplicação pode ser executada em qualquer um dos nós. O sistema é composto por três centros de serviços sendo eles: processador, disco e interface de rede. Nesse modelo o processo é tratado como um token e circula pelo sistema a fim de consumir seu tempo de execução. Na figura 5.1 é possível visualizar o modelo de redes de filas para esse sistema.

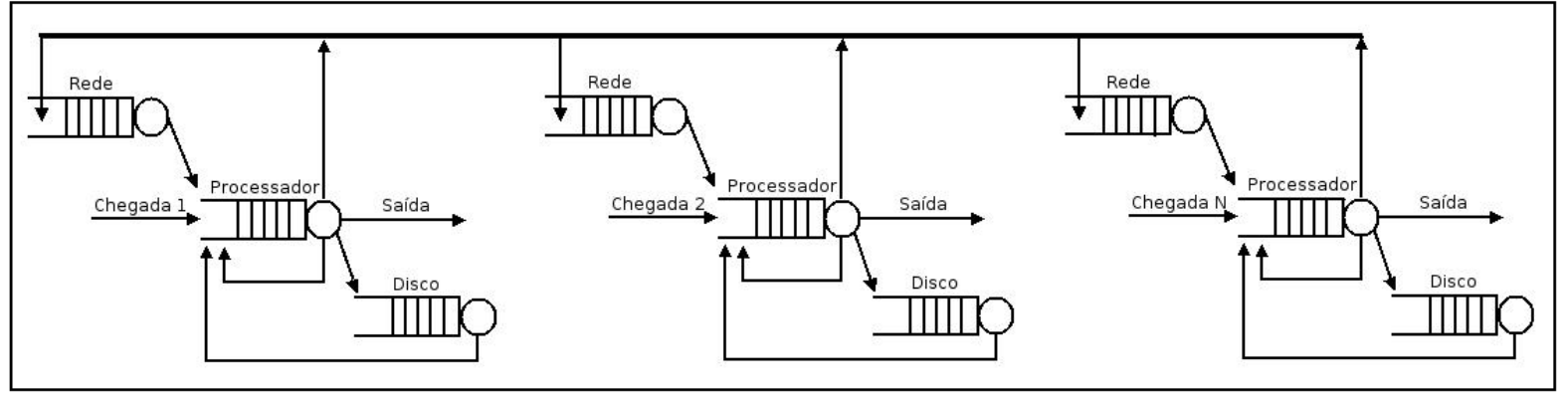

Figura 5.1: Modelo do sistema.

Conforme pode ser observado, um processo é submetido em uma máquina expecífica, sendo armazenado na fila de prontos da $C P U$. Caso esse processo seja o primeiro da fila, ele ocupará o centro de serviço processador, podendo sofrer ações do sistema tais como:

Voltar para a fila de prontos: Um processo ocupará o centro de serviço processador até que seu quantum seja consumido; caso seu tempo de processamento tenha sido 
atingido ele deixará o sistema, caso contrário, retornará para o final da fila de prontos, permitindo assim a utilização da $C P U$ por outro processo, uma vez que o Linux adota a técnica de preempção.

Ser enviado para a rede: Ao ocupar o centro de serviço processador, um processo novo poderá ser enviado para outra máquina do sistema, caso seja essa a decisão tomada pela política de transferência. Ao ser enviado para execução remota, o processo deixará o centro de serviço processador, da máquina de origem, e será enviado para a fila do centro de serviço rede, da máquina de destino.

Em um ambiente real, o processo é enviado para a placa de rede da máquina de origem, que realiza a transferência para a placa de rede da máquina de destino. Entretanto, como a comunicação nas redes utilizadas, atualmente, na implementação de clusters são full-duplex, seria incorreto implementar no modelo a transferência utilizando os centros de serviços rede tanto da origem quando do destino, pois, o processo seria penalizado duas vezes, o que não ocorre nas redes reais. Assim, um processo será enviado diretamente do centro de serviço processador, da máquina de origem, para o centro de serviço rede da máquina de destino, levando o processo a gastar tempo de espera em fila apenas uma vez.

Ao ocupar o centro de serviço rede da máquina de destino, um processo consumirá o tempo determinado para uma transferência e será envido para o final da fila de prontos da $C P U$, ou seja, será enviado para a fila do centro de serviço processador.

Ser enviado para o disco: Durante o período em que o processo está ocupando o centro de serviço processador, poderá ocorrer uma ausência maior de página ${ }^{1}$, o que causará a transferência desse processo para o centro de serviço disco, onde o mesmo deverá permanecer pelo tempo determinado para tratar uma ausência de página, sendo novamente enviado para o final da fila de prontos da $C P U$, como descrito no caso anterior.

A simulação por traces será utilizada para resolver o modelo apresentado. Nesse tipo de simulação, um arquivo com informações de sistemas reais é utilizado para "alimentar" o simulador [36].

Os traces utilizados neste trabalho são os mesmos descritos em [34], [6] e [33]. Esses arquivos contêm as seguintes informações:

- Tempo de chegada;

- Máquina de destino;

\footnotetext{
${ }^{1}$ Tratada deste ponto em diante apenas como ausência de página.
} 
- Tempo de processamento;

- Quantidade de memória DRAM utilizada;

- Nome do processo.

O primeiro campo do arquivo informa o momento da chegada do processo no sistema, devendo estar em milisegundos. O segundo campo indica a máquina em que o processo foi submetido, sendo seguido pelo seu tempo de processamento, expresso em MIPS (Millions of Instructions Per Second). A quantidade de memória utilizada deverá estar expressa em KB. O nome do processo é o último campo do registro, possibilitando a indentificação do processo, mas, esse campo não será utilizado para realizar o escalonamento, uma vez que o sistema descrito não possui informações sobre as aplicações, realizando o escalonamento dinâmico.

Um exemplo de trace pode ser visualizado na figura 5.2

\begin{tabular}{|c|c|c|c|c|}
\hline 21600.00. & 4. & 0.50 . & 564. & ls \\
\hline 21600.30 & 0. & 3.00 . & 641. & as 02.1 \\
\hline 21600.40 & 5. & 2.00 & 1119. & uname \\
\hline 21600.60. & 4. & 22.00 & 745. & mips-tfile \\
\hline 21600.60 & 5. & 0.50 & 702. & clear \\
\hline 21600.90. & 1. & 2.00 & 36781. & sed \\
\hline 21601.00. & 5. & 962.00. & 712. & $\operatorname{trn}$ \\
\hline 21601.30. & 5. & 2.00 & 823. & sed \\
\hline 21601.40. & 4. & 19.00. & 2071. & telnetd \\
\hline 21601.40. & 5. & 3.00 & 1366. & ls \\
\hline 21601.90. & 0. & 2.00 & 513. & from \\
\hline 21601.90. & 5. & 0.50. & 480. & stty \\
\hline 21602.00 & 5. & 8.00 & 560. & more \\
\hline 21602.20 & 0. & 0.50 & 447. & ls \\
\hline 21602.20 & 1. & 2.00 & 739. & whoami \\
\hline 21602.60 & 1. & 6.00 & 445. & as 02.1 \\
\hline 21602.60 . & 1. & 61.00 & 1334. & mail \\
\hline 21602.80 & 1. & 23.00 & 801. & $\mathrm{cpp}$ \\
\hline 21603.00 & 4. & 92.00 & 485. & finger \\
\hline 21603.20 & 4. & 3.00 & 1705. & sendmail: 8 \\
\hline 21603.30 & 0. & 3.00 & 1112. & sed \\
\hline 21603.30 & 0. & 12.00 & 1846. & $\mathrm{gcc}$ \\
\hline 21603.30 & 4. & 56.00 & 769. & as 02.1 \\
\hline 21603.30 & 5. & 0.50 & 648. & stty \\
\hline 21603.40 & 4. & 6.00 & 467. & a.out \\
\hline 21603.50 & 0. & 2.00 & 460. & $\mathrm{rm}$ \\
\hline 21603.60 & 1. & 3.00 & 475. & sed \\
\hline 21603.60. & 4. & 2.00 & 611. & ls \\
\hline 21603.70. & 5. & 158.00. & 2276. & as12.1 \\
\hline
\end{tabular}

Figura 5.2: Arquivo de trace. 
O sistema modelado não trabalhará com migração preemptiva de processos, uma vez que em [6] concluiu-se que a execução remota é mais eficiente em sistema em que há aplicação memory-intensive. No entanto, o simulador modelado permite realizar migrações, uma vez que o mesmo foi desenolvido para ser uma ferramenta completa para simular sistemas distribuídos de imagem única.

\subsection{Modelagem do simulador}

Na revisão bibliografica realizada, um simulador em especial se destacou, sendo desenvolvido originalmente em [37] e aperfeiçoado em [34] e [6]. Esse simulador é capaz de simular ambientes de cluster com middleware de imagem única. Em [33] esse simulador foi modificado para tratar sistemas de clusters de imagem única. Esse aplicativo foi validado através de instrumentação no kernel 2.0.x do sistema operacional Linux em [6], apresentando resultados aproximados. No entanto, muitas características presentes no Linux foram omitidas e outras inseridas, como por exemplo, o escalonamento baseado em nomes.

Ao utilizar o escalonamento baseado em nomes é possível privilegiar algumas aplicações, uma vez que o sistema conhece quais processos podem, ou não, ser migrados. Essa característica não é desejada, pois, o ambiente a ser simulado deve executar o escalonamento dinâmico de aplicações, utilizando apenas informações sobre a plataforma, deixando a cargo das políticas armazenar informações sobre as aplicações quando desejado.

Dessa forma, esse simulador apresentou-se como uma boa base para o desenvolvimento do simulador apresentado neste trabalho. Porém, muitas características foram modificadas para descrever o comportamento de um sistema de imagem única utilizando as novas gerações do núcleo do Linux. À medida que o projeto do simulador for apresentado, neste texto, as novas características inseridas serão descritas, bem como as que foram retiradas ou modificadas serão destacadas.

\subsubsection{Visão de casos de uso}

No início do desenvolvimento do simulador, alguns casos de uso foram estabelecidos para indicar a usabilidade do software. Esses casos de uso podem ser visualizados na figura 5.3.

A primeira característica desejada no novo programa é a possibilidade de configuração do ambiente de simulação. Dessa forma, optou-se por realizar essa tarefa por meio de um arquivo de configuração, permitindo que as configurações fossem salvas para uso futuro. 


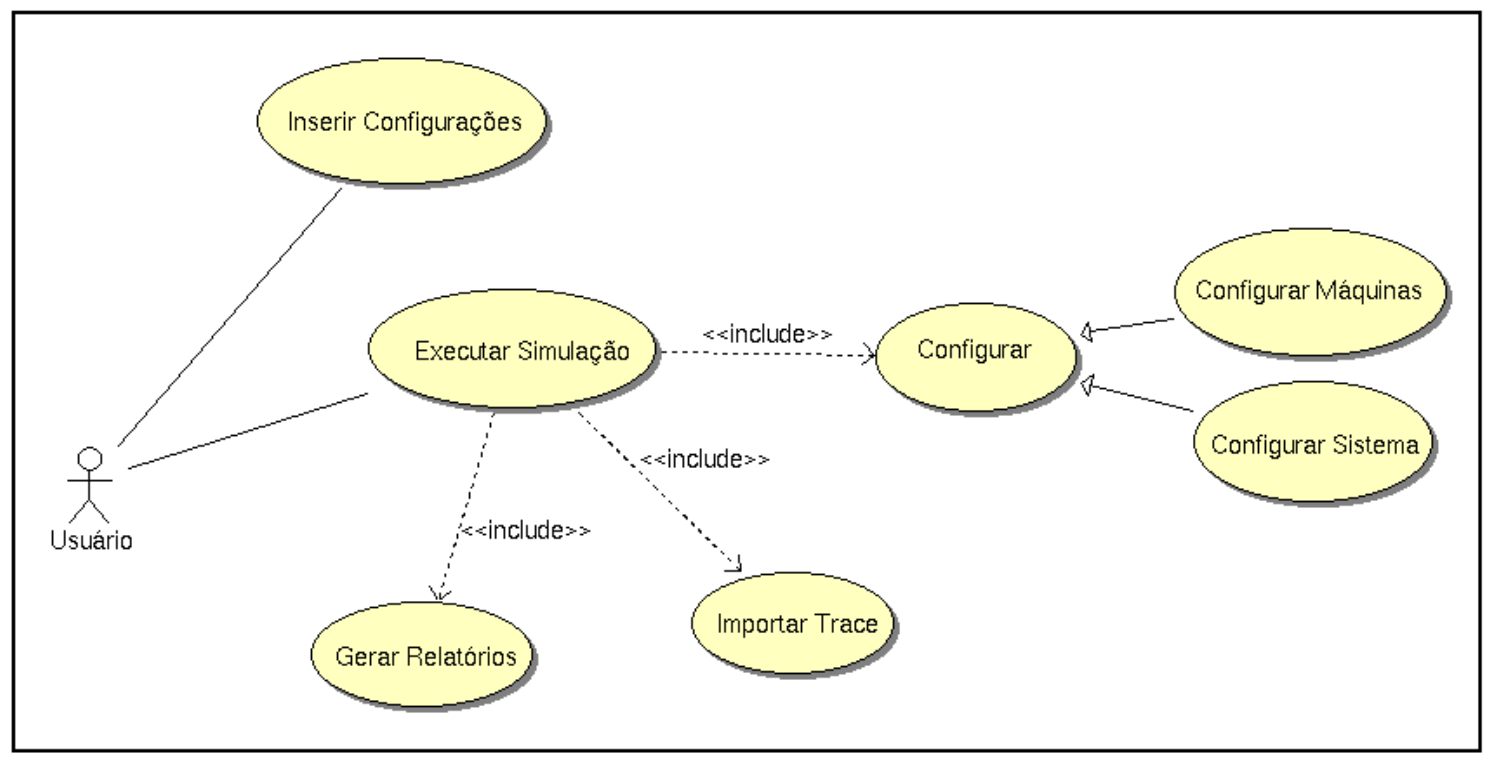

Figura 5.3: Diagrama de casos de uso.

Outra vantagem, da utilização de um arquivo de configuração, é a agilidade em se realizar uma nova simulação, com a plataforma alterada, sendo necessário modificar apenas os itens do arquivo que caracterizam o novo sistema, diferente do simulador utilizado como base, que obtinha os parâmetros de entrada na linha de comandos.

A entrada dos parâmetros na linha de comandos seria extremamente tediosa, uma vez que o novo simulador possui muitos parâmetros, podendo dificultar a sua utilização.

Na figura 5.4 é possível analisar o conteúdo de um arquivo característico, utilizado em uma das simulações deste trabalho.

Na figura apresentada não constam todos os campos que devem ser informados no arquivo de configuração, mas, é possível perceber que seria pouco conveniente fornecer essas informações como parâmetros no momento da execução do simulador.

O módulo de configuração do simulador ignora as linhas que começam com o caracter "\#", permitindo a inserção de comentários no arquivo de configuração. Esse caracter foi selecionado por ser o mesmo utilizado para comentar arquivos de script do Bash ${ }^{2}$. Os parâmetros devem estar em letras minúsculas e não possuem ordem de precedência.

As entradas que devem estar presentes no arquivo de configuração são:

- trace: Deve conter o nome completo, ou relativo, do aquivo que será utilizado como trace para a simulação. Esse arquivo deve conter um registro de processo por linha, apresentando os campos descritos anteriormente.

- relatório: Deve conter o nome completo, ou relativo, do arquivo em que será gravado

\footnotetext{
${ }^{2} \mathrm{O}$ Bash (Bourne Again SHell) é o interpretador padrão de comandos, shell, do Linux
} 


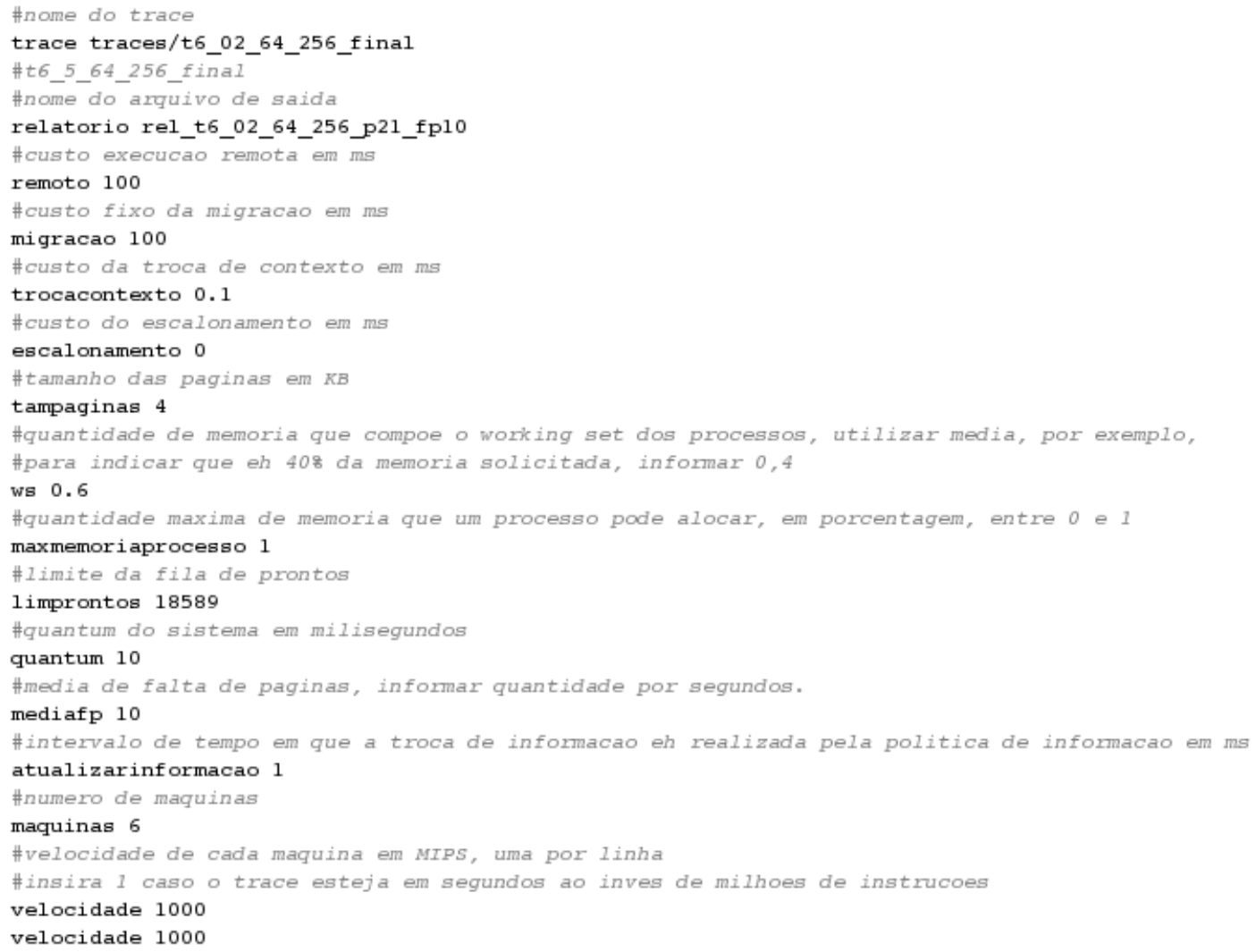

Figura 5.4: Arquivo de configuração.

o relatório da simulação realizada.

- remoto: Informa, em milisegundos (ms), o custo fixo para realizar a execução remota. Esse custo é fixo, pois o processo não é inicializado na máquina de origem, descartando a necessidade de enviar, para a máquina remota, o estado do processo, juntamente com a sua pilha de dados, uma vez que a utilização de sistemas de arquivos distribuídos, como o Network File System (NFS), é comum em sistemas de imagem única. Dessa forma, o custo fixo atribuído se refere ao tempo gasto com a notificação e sincronização entre os nós envolvidos [6].

- migracao: Deve conter, também em ms, o tempo fixo para realizar a migração de processos. De acordo com [37] e [34] a migração de processos envolve um custo fixo, necessário para sincronismo e troca de informações entre os nós, e um custo variável dado por $\frac{\text { Quantidade de dados }}{\text { Taxa da Rede }}$, que dimensiona o tempo gasto para transferir o estado do processo da máquina de origem para a máquina de destino.

- trocacontexto: Tempo gasto, em ms, para realizar a troca de contexto, entre o modo usuário e o modo núcleo.

- escalonamento: Custo, em ms, atribuído à atividade de escalonamento. Nas si- 
mulações executadas neste trabalho, nenhum custo foi atribuído ao escalonamento, seguindo as propostas apresentadas em [6] e [33]. No entanto, essa informação está presente no simulador desenvolvido, pois, em outras ocasiões, ele pode ser fundamental, como para decidir entre implementações diferentes da mesma política.

- tampaginas: Informa a quantidade de memória, em KB, que constitui uma página, que é gerenciada pelo núcleo do sistema operacional. Atualmente, no Linux, uma página ocupa 4KB na plataforma 1386 e derivadas, sendo esse o valor utilizado nas simulações deste projeto. O tamanho da página utilizada pelo núcleo, em uma máquina executando Linux, pode ser obtida através da chamada ao sistema int getpagesize(), que possui sua interface definida em unistd.h. Esta chamada retorna o conteúdo da variável PAGE_SIZE, que é definida pelo módulo de gerenciamento de memória.

Na implementação do simulador utilizado neste trabalho, a quantidade de páginas, atribuídas a uma máquina, é igual à divisão inteira da quantidade de memória fornecida no arquivo de configuração, pelo tamanho da página. Assim, é possível que uma pequena parte da memória fornecida não seja utilizada, uma vez que o sistema operacional abordado trabalha apenas com páginas inteiras, descartando fragmentos de memória.

- ws: Define qual a porcentagem da memória solicitada pelos processos que deve ser considerada como working set. Essa informação é utilizada tanto no momento da alocação de página por um processo em um nó do sistema simulador, quanto na função que calcula o tempo para ocorrer a próxima ausência de página.

- maxmemoriaprocesso: Este campo é utilizado para informar qual a porcentagem da memória principal que um processo pode alocar. Esse valor deve estar entre zero e um. Quando configurado como um, significa que um único processo pode alocar toda a memória existente na máquina. Atualmente, no núcleo 2.6.x, quando um processo aloca toda a memória disponível no nó, ele recebe um sinal de finalização, sendo morto. Assim, durante as simulações utilizadas neste trabalho, esse valor foi configurado em um, "matando" todos os processos que solicitam uma quantidade de memória maior que a quantidade existente no nó em que o processo foi submetido.

Esse item de configuração se faz necessário uma vez que, muitos traces possuem registros contendo uma quantidades de memória maiores que o total existente na máquina em que o mesmo foi submetido, podendo distorcer os resultados da simulação, caso esse processo não seja "morto". Esta foi uma das novas características adicionadas ao novo simulador e que não estava presente no software de referência.

- limprontos: Esta entrada informa a quantidade máxima de processos suportados 
pela fila de prontos sendo que, será rejeitado todo processo submetido a um nó, cuja fila de prontos encontra-se no limite máximo.

Neste trabalho configurou-se essa entrada com o valor 18589, sendo este o valor padrão encontrado no código, não modificado, do kernel. Esse valor pode ser obtido por meio da chamada ao sistema int getrlimit(int, struct rlimit *). Esta chamada retorna na variável struct rlimit do tipo ponteiro, uma referência para a estrutura rlimit, que contém, entre outros, o campo rlin_t rlim_cur, cujo conteúdo pode ser escrito através do comando printf com o formatador \%i. Nesse campo está armazenada a quantidade máxima, atual, de processos, que podem ser armazenados na fila de prontos. A estrutura rlimit contém, ainda, o campo rlim_max, que é o valor máximo que pode ser configurado, para a quantidade de processos na fila de prontos, que na versão padrão do kernel é de 85472 processos. O valor corrente pode ser alterado no kernel através da chamada int setrlimit(int, const struct rlimit*).

O primeiro parâmetro da chamada getrlimit é o código do recurso a ser analisado, uma vez que essa chamada ao sistema é utilizada para analisar o valor corrente e máximo de muitos recursos. O valor desse parâmetro, para visualizar os valores atual e máximo do limite de processos na fila de prontos, deve ser a constante RLIMIT_NPROC.

As funções e constantes, descritas neste item, encontram-se declaradas em sys/resource.h e unistd.h.

- quantum: Informa o tempo, em ms, do quantum atribuído a um processo. Após esse período o sistema operacional recebe uma interrupção e realiza a preempção, atribuindo, caso exista, outro processo ao processador.

- mediafp: Nesta variável é armazenada a média de ocorrência de ausências de páginas, por milhões de instruções executadas, causadas por um processo, cuja quantidade de páginas destinadas ao seu working set seja menor que a quantidade requerida.

A quantidade de ausências de páginas causadas por um processo, é proporcional à diferença entre a quantidade de páginas alocadas a ele, e a quantidade de páginas solicitadas para o seu working set, sendo dado por 5.1, onde mem. Solicitada ${ }_{j}^{i}$ é a quantidade de páginas solicitadas pelo processo $i$ na máquina $j$ e mem. Alocada ${ }_{j}^{i}$ é a quantidade de páginas alocadas ao processo $i$ na máquina $j$.

$$
\sigma * \frac{\text { Mem. Solicitada }}{i}
$$

Caso um processo cause muitas ausências de páginas, o efeito poderá ser propagado em outros processos e até mesmo no nó, pois, como consequência das ausências 
de páginas, muitas páginas serão retiradas de outros processos, que podem ter seu working set não estabilizado, levando à novas ausências de páginas, propagando esse efeito para os outros processos no mesmo nó, podendo levar o nó ao estado de trashing.

De acordo com [6], essa média, denotada por $\sigma$, varia entre um e dez em uma plataforma real. Assim, o valor informado na entrada mediafp deve estar entre estes extremos.

- atualizarinformacao: Nesta entrada deve ser informado o intervalo de tempo, em ms, entre as sincronizações realizadas pelas políticas de informação, uma vez que o ambiente simulado trabalha com a troca de informação por intervalos de tempos determinados, utilizando mensagens em broadcast.

- maquinas: Informa a quantidade de máquinas que constituem o sistema distribuído de imagem única.

- velocidade: Nesta entrada é informada a velocidade, em MIPS, de cada máquina do sistema, devendo haver uma entrada para cada máquina que constitui o sistema.

- memoria: Registra a quantidade de memória DRAM presente em cada nó, sendo informada em MB.

- PoliticaTrans: Assim como as duas informações anteriores, esse campo também deve ter uma entrada para cada máquina presente no sistema, informando o número da política de transferência. As entradas individuais admitem que cada máquina utilize uma política de transferência diferente, permitindo simular sistemas com escalonamento centralizado, como o exemplo mostrado no modelo da figura 5.5

- politicamig: Assim como o campo anterior, deve haver uma entrada com este parâmetro para cada máquina do sistema, informando o número da política de migração. Novamente, é possível inserir políticas de migração diferentes para cada nó que constitui o sistema distribuído.

- politicasel: Informa o número da política utilizada para selecionar o processo a ser migrado em cada computador presente na plataforma distribuída.

- fp: Indica o tempo gasto, em ms, para tratar uma ausência de página, isto é, o tempo gasto para realizar as operações de swap in e swap out. Esse tempo está ligado diretamente à velocidade do disco rígido. Assim, ao testar plataformas com discos de velocidades diferentes, devem-se configurar proporcionalmente os valores dessa variável. 


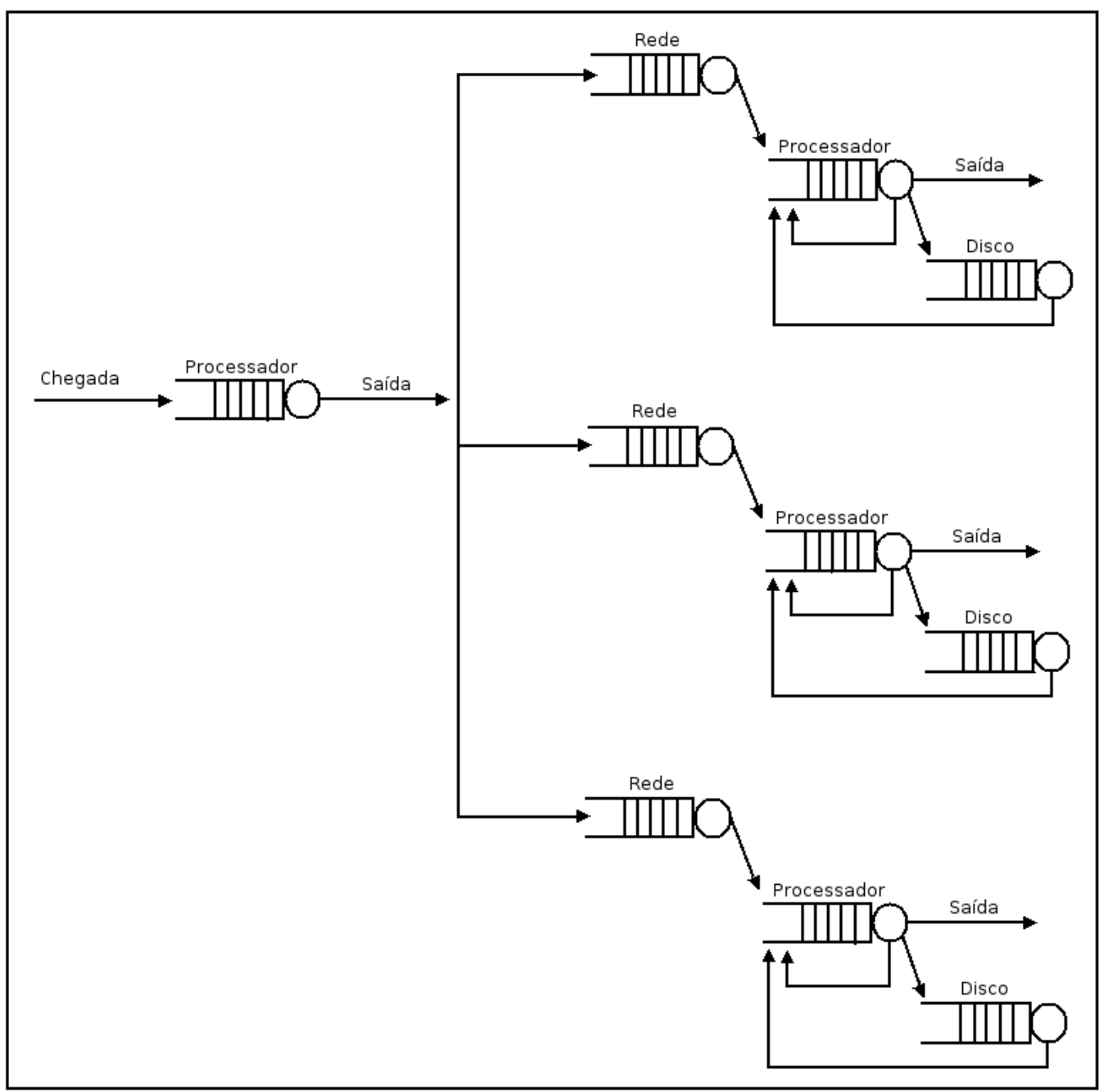

Figura 5.5: Modelo de sistema com escalonamento centralizado.

- rede: Finalmente, este item armazena a taxa de transmissão da rede, sendo utilizada no cálculo do tempo gasto na migração de processos.

Após realizar a configuração do simulador, através do arquivo de configuração, o usuário poderá executar a simulação e obter os resultados no arquivo de relatório especificado na entrada "relatorio", como descrito anteriormente.

Esse arquivo divide-se em duas partes. Na primeira constam as configurações utilizadas na plataforma, contendo boa parte dos campos encontrados no arquivo de configuração, permitindo identificar a plataforma em que a simulação foi executada e possibilitando a reconfiguração da mesma, caso seja necessário executar outras simulações alterando, ou não, alguns parâmetros. A segunda parte do arquivo contém os resultados da simulação, como pode ser visualizado na figura 5.6

No início da segunda parte do arquivo de relatório, há informações gerais sobre os resultados da simulação, como segue: 


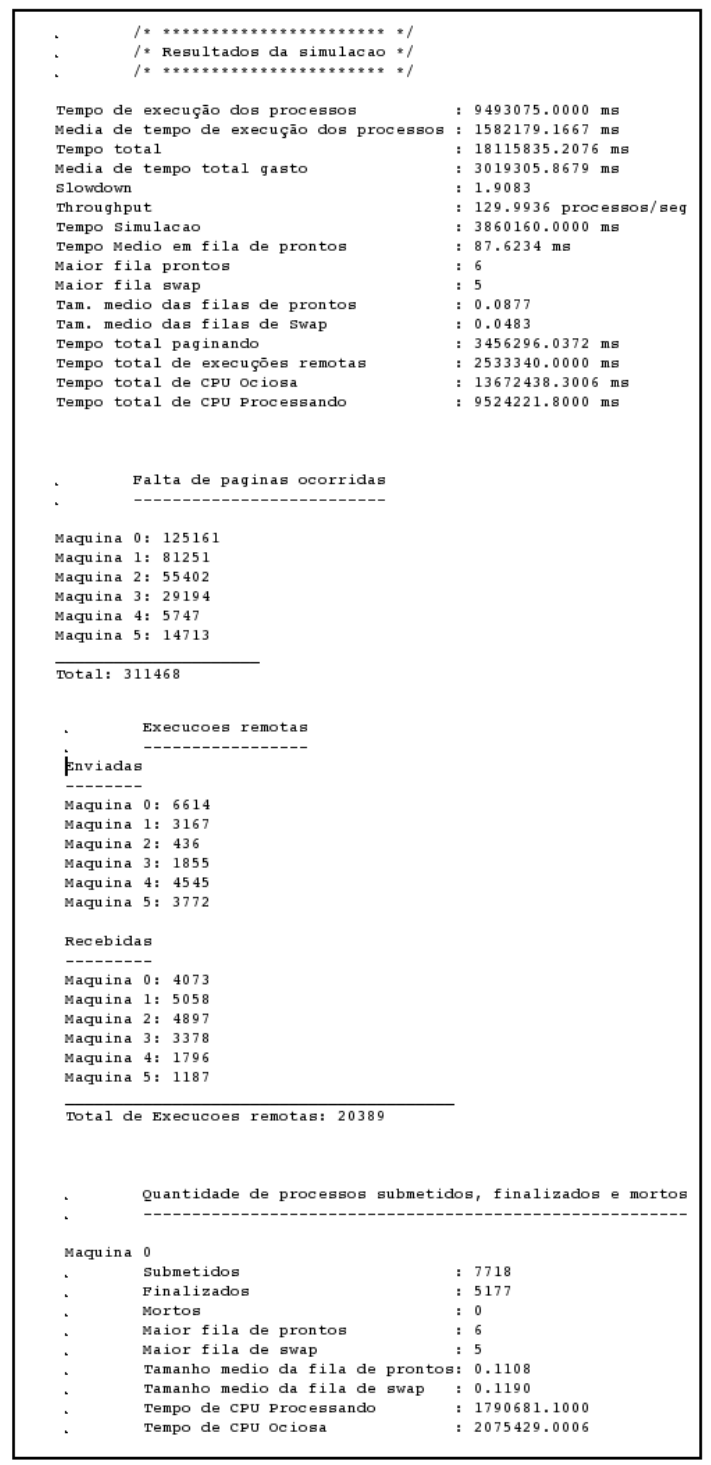

Figura 5.6: Segunda parte do arquivo de relatório.

- Tempo de execução dos processos: Definido como $\sum_{j=0}^{m} \sum_{i=0}^{n} T e m p o C P U_{j}^{i}$, onde Tempo $C P U_{j}^{i}$ é o tempo de processador gasto pelo processo $i$ na máquina $j$, sendo $m=Q t d$. Maquinas - 1. Assim, esse é o tempo total de processador gasto por todos os processos que foram executados no sistema.

- Média do tempo de execução dos processos: Informa a média do tempo de execução dos processos por máquina. Dessa forma, o valor informado nesse campo é o resultado da divisão entre o tempo de execução dos processos, entrada anterior, pela quantidade de máquinas presente no cluster.

- Tempo total: É a soma de todos os tempos gastos pelos processos que foram executados no sistema, incluindo:

$$
\text { - Tempo CPU; }
$$


- Tempo na fila de prontos;

- Tempo paginando;

- Tempo realizando tranferências (execução remota e/ou migração).

- Média tempo total gasto: É dada pela razão entre o tempo total gasto e a quantidade de máquinas presentes na plataforma.

- Slowdown: É a razão entre o tempo total gasto e o tempo total de processador gasto pelos processos.

- Throughput: Informa a quantidade de processos finalizados por segundo.

- Tempo de Simulação: É o tempo total da simulação, não correspondendo ao tempo cronológico, real, gasto para executar a simulação.

- Tempo médio em fila de prontos: Armazena o tempo médio gasto pelos processos nas filas de prontos do sistema distribuído.

- Maior fila prontos: Armazena a maior quantidade de processos enfileirados na fila de prontos, independente do nó. Essa informação é verificada na finalização de cada quantum. O mesmo se aplica à fila de swap, que possui seu registro no campo maior fila de swap.

- Tam. médio da fila de prontos: Armazena o tamanho médio da fila de prontos, sendo verificado ao final de cada quantum. O mesmo se aplica ao tam. médio da fila de swap.

- Tempo total paginando: Armazena, em ms, o tempo total que os processos gastaram tratando ausências de páginas, seja realizando as operações de swap in e swap out, ou aguardando na fila do disco.

- Tempo total de execuções remotas: Registra o tempo total gasto pelos processos realizando execuções remotas, incluindo o tempo de transferência e o tempo aguardando em fila para iniciar o processo de envio de dados.

- Tempo total $C P U$ ociosa: É o tempo total em que todas as CPUs firam sem realizar computação útil, devido à ausência de processos no sistema ou em algum nó específico.

- Tempo total de $C P U$ processando: Ao contrário da informação anterior, esse campo armazena o tempo total gasto por todos os nós do sistema, para executar os processos submetidos. 
Na parte final do arquivo de relatório, é possível encontrar informações destinadas a cada máquina que constitui o sistema distribuído, sendo elas:

- Falta de páginas ocorridas: Informa a quantidade de ausência de páginas ocorridas durante a execução do trace.

- Execuções remotas: Contém a quantidade de execuções remotas realizadas por cada nó do cluster, dividindo-se em execuções enviadas e recebidas.

- Submetidos: Registra a quantidade de processos submetidos originalmente naquele nó.

- Finalizados: Informa a quantidade de processos que foram finalizados naquele nó. Esse valor pode diferir do anterior devido às execuções remotas e migrações realizadas e, também, à quantidade de processos "mortos".

Os outros campos que expecificam informações sobre um nó específico, são os mesmos citados para a plataforma como um todo, porém, tratando apenas de uma máquina do sistema.

\subsubsection{Visão estrutural}

Para realizar os casos de uso descritos anteriormente, o diagrama de classes foi definido conforme apresentado na figura 5.7.

A classe simulador é a responsável por gerenciar a simulação, controlando o tempo e disparando os eventos dos objetos da classe máquina, à medida que eles devam ocorrer. A classe simulador é constituída de $n$ classes máquinas e uma fila de chegada, que contém os processos importados do trace. A classe simulador é formada, ainda, por uma classe carga de trabalho, que armazena as informações fornecidas pela política de informação implemtada na classe máquina.

A implementação de uma classe carga de trabalho facilita o processo de simulação, evitando armazenar dentro de um objeto máquina, informações sobre todas as outras.

A classe máquina, por sua vez, é constituída pelas filas:

- Prontos: Armazena os processos que estão aguardando para ocupar o processador por um quantum;

- Swap: Contém os processos que estão aguardando o tratamento das ausências de páginas sofridas. 


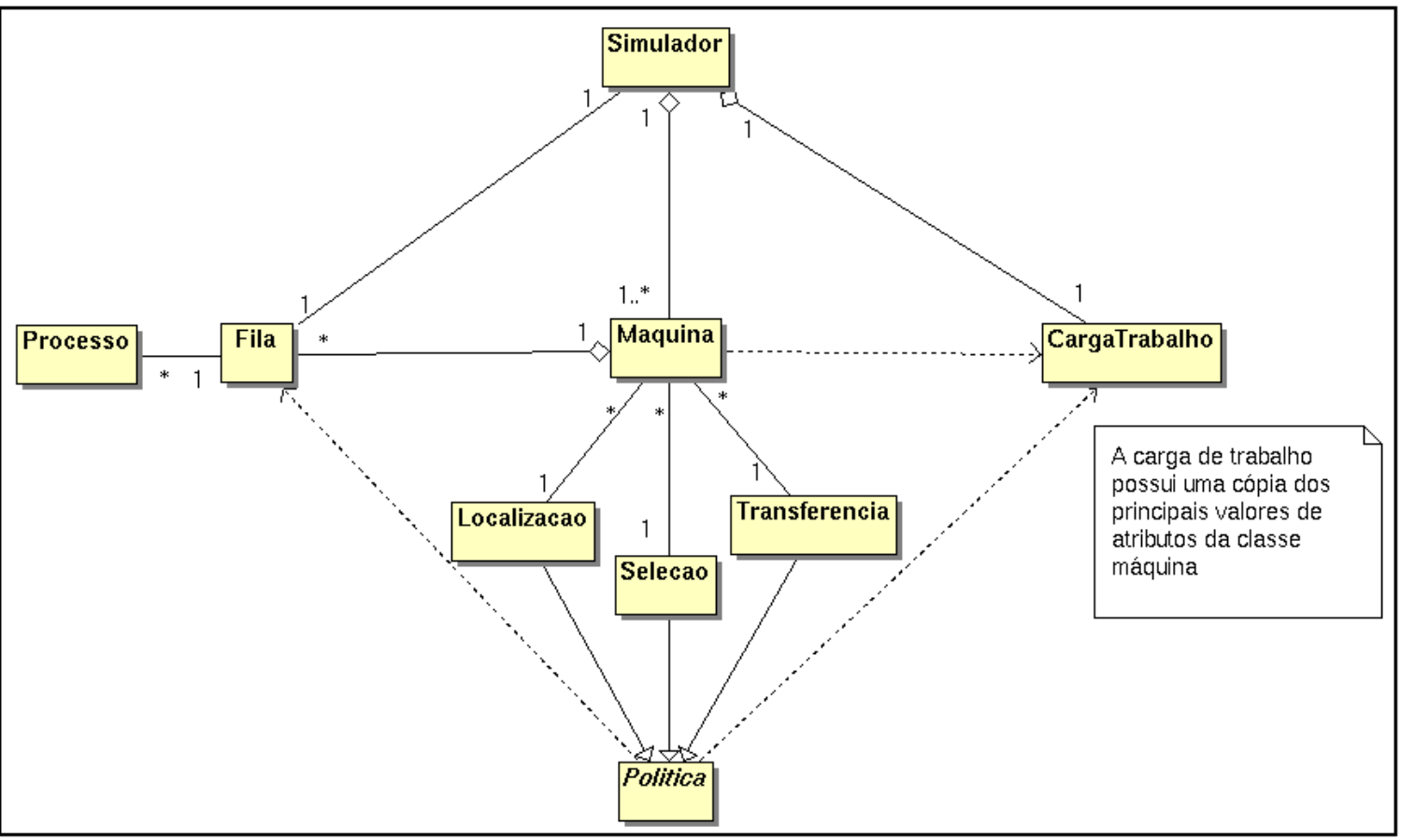

Figura 5.7: Diagrama de classes.

- Finalizados: Armazena os processos que foram finalizados no objeto máquina.

- Mortos: Contém os processos que foram mortos por solicitar uma quantidade de memória maior que a permitida pelo sistema ou, por chegar ao nó quando a fila de prontos já estava com o tamanho máximo permitido.

- Transferindo: Suporta os processos que estão chegando pela rede, através de uma operação de migração ou execução remota. Essa operação é realizada somente na máquina de destino, conforme descrito no início deste capítulo.

A classe máquina implementa a política de informação, sendo constituída, também, de três classes políticas, sendo elas:

- Transferencia: Responsável por decidir se uma execução remota deve ser realizada no momento em que um processo chega ao nó para execução. Essa classe decide também para qual máquina o processo deve ser enviado. Essa tarefa poderia estar na política de localização, mas por uma questão de praticidade foi inserida diretamente na política de transferência.

- Localizacao: Esta política deve decidir se uma migração de processos deve ser realizada.

- Selecao: Responsável por decidir qual processo deve ser migrado, logo após a política de localização decidir que uma migração se faz necessária. 


\subsubsection{Visão comportamental}

A partir deste ponto é possível difinir as atividades gerais realizadas pelo simulador, constituindo o mecanismo de funcionamento do mesmo. O digrama apresentado na figura 5.8 apresenta uma visão de alto nível das atividades realizadas pelo simulador.

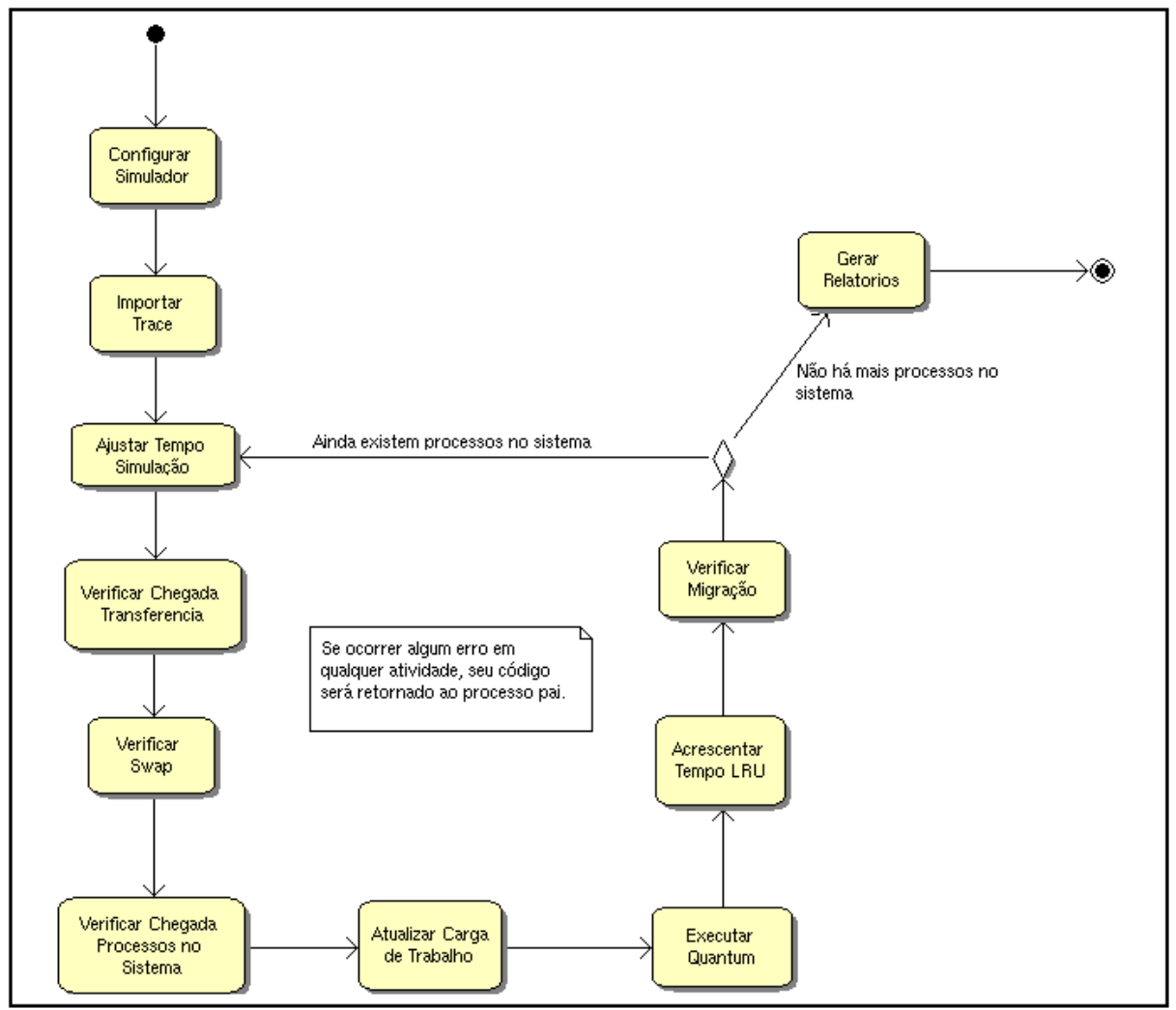

Figura 5.8: Diagrama de atividades: Geral.

Conforme pode ser observado, inicialmente o simulador importa as configurações cadastradas no arquivo de configuração e o arquivo de trace, inserindo os processos na fila de chegada do objeto simulador instanciado e responsável pela simulação. A fila de chegada dos processos é organizada cronologicamente, de acordo com os tempos de chegada registrados no trace.

Após realizar essas duas tarefas, o objeto simulador entra em um ciclo até que todos os processos obtidos do arquivo tenham sido concluídos ou "mortos", sendo essa a condição que marca o fim da simulação e a geração do arquivo de relatório.

A primeira tarefa a ser realizada é o ajuste do tempo de simulação, que segue as atividades descritas na figura 5.9

Como pode ser observado, a unidade básica de tempo do simulador é o quantum. Essa abordagem foi utilizada em diversos trabalhos disponíveis na literatura, tais como [37],[34], [6], [32] e [33]. 


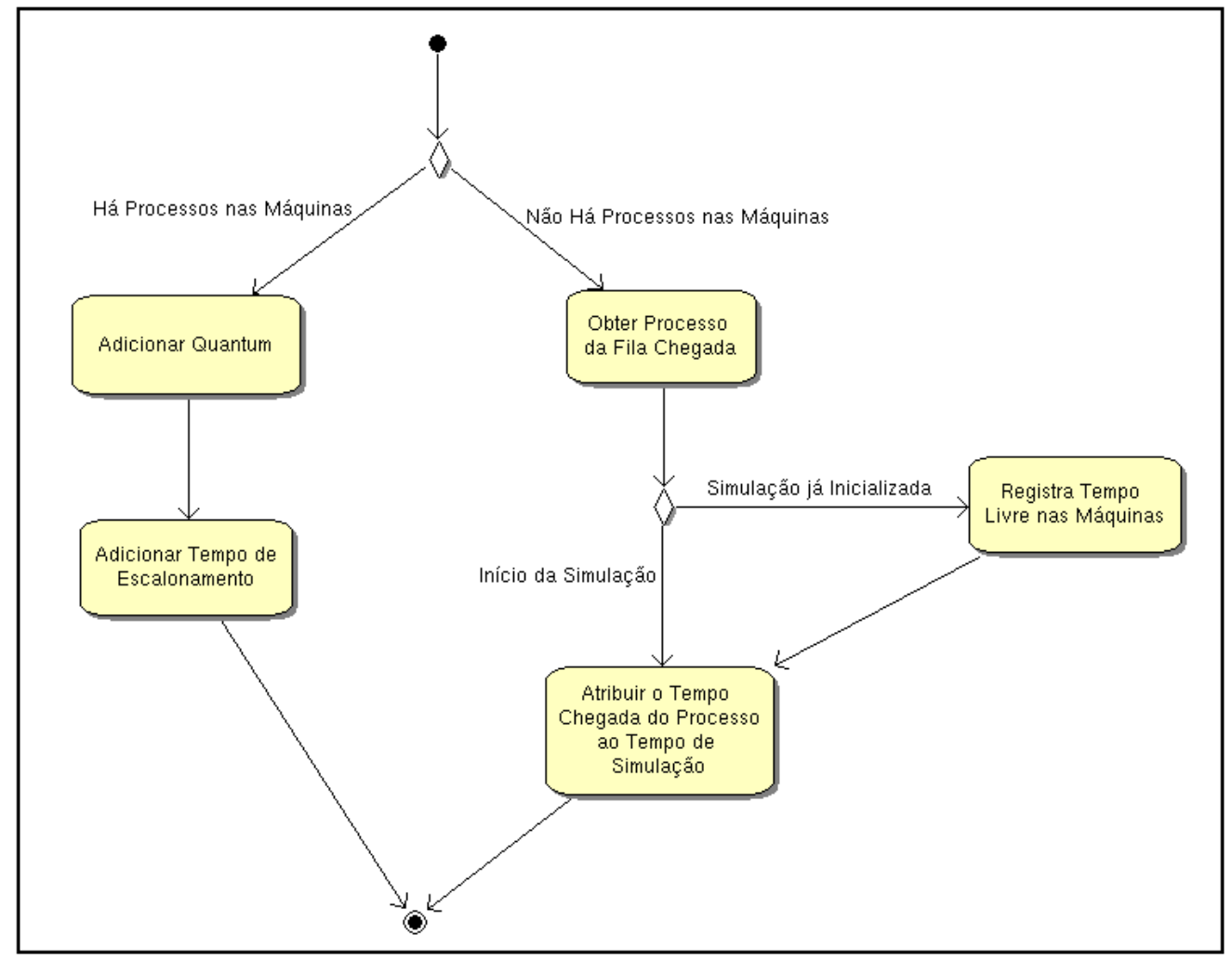

Figura 5.9: Diagrama de atividades: Ajustar tempo da simulação.

Primeiramente é verificado se a simulação está no início; caso afirmativo, o tempo será ajusto para a chegada do primeiro processo; caso contrário, será acrescido de um quantum adicionado ao tempo de escalonamento, caso existam processos armazenados em pelo menos um nó, seja na fila de prontos, swap ou transferindo. Caso não existam processos nos computadores do sistema, o tempo será avançado para a chegada do próximo processo ao sistema, incrementando o tempo ocioso das máquinas do cluster.

A próxima atividade a ser executada é a verificação da chegada de transferência, que deve retirar o processo da fila de rede (transferindo) e inserí-lo na fila de prontos, caso o tempo necessário para realizar a tranferência, informado no arquivo de configuração, tenha sido atingido, indicando o final da transferência do processo. O diagrama de atividades que descreve, em passos mais detalhados, essa atividade macro pode ser visualizado na figura 5.10

A atividade de transferência deve ser realizada antes da execução do quantum, pois este avança o tempo do simulador; assim, os processos que finalizaram a transferência pela rede, terão oportunidade de ser executados no próximo quantum.

Da mesma forma, a atividade de verificar os processos que podem deixar a fila do disco para voltar para a fila de prontos, deve ser executada antes de executar o quantum, sendo essa a atividade executada logo após a verificação de chegada da transferência. O 


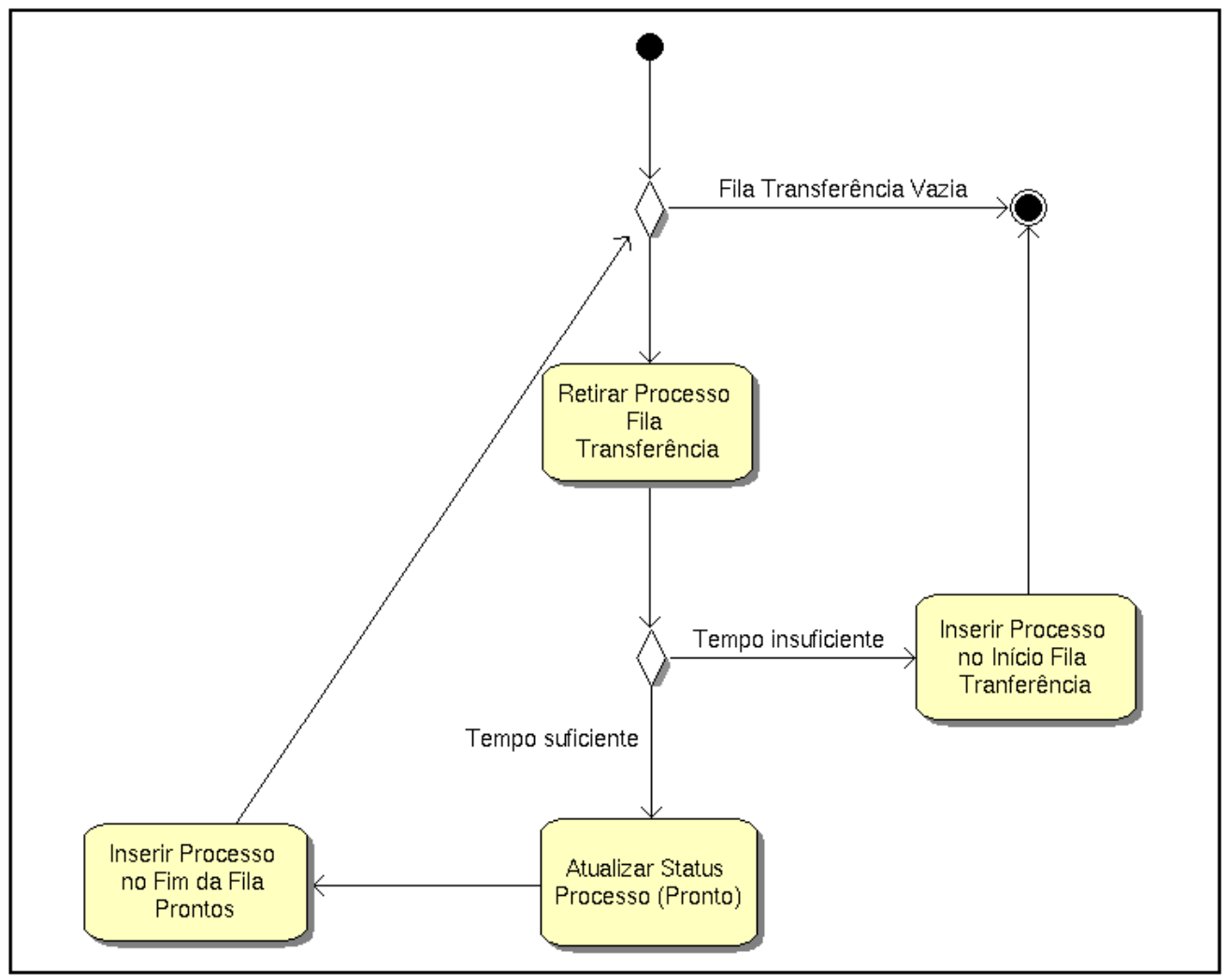

Figura 5.10: Diagrama de atividades: Verificar chegada de transferência.

diagrama de atividades, que explora essa tarefa a ser realizada, pode ser visualizado na figura 5.11

Ao ser invocado, o método da classe máquina, responsável por verificar e retirar os processos da fila de swap, verifica se o primeiro processo da fila, caso exista, já completou o tempo necessário para tratar uma ausência de página, informado no arquivo de configuração através da entrada "fp". Caso positivo, uma página deve ser atribuída ao processo, sendo que ela pode ser retirada da própria máquina, caso existam páginas livres para serem ocupadas, devido à finalização de um processo, ou deve ser retirada de um outro processo.

No primeiro caso, uma nova página é atribuída ao processo que está deixando o disco e a quantidade de memória disponível na máquina é subtraída. No segundo caso, a página menos recentemente utilizada é retirada de um processo que esteja na fila de prontos; caso não existam processos na fila de prontos, essa página será retirada de um processo que está na fila de swap, o que provavelmente ocasionará uma nova ausência de página no processo que cedeu a página. Essa característica indica que a máquina está entrando em trashing.

Em muitos casos o processo pode doar uma página para ele mesmo. Isso ocorre em situações em que a quantidade de páginas alocadas pelo processo é muito grande, fazendo 


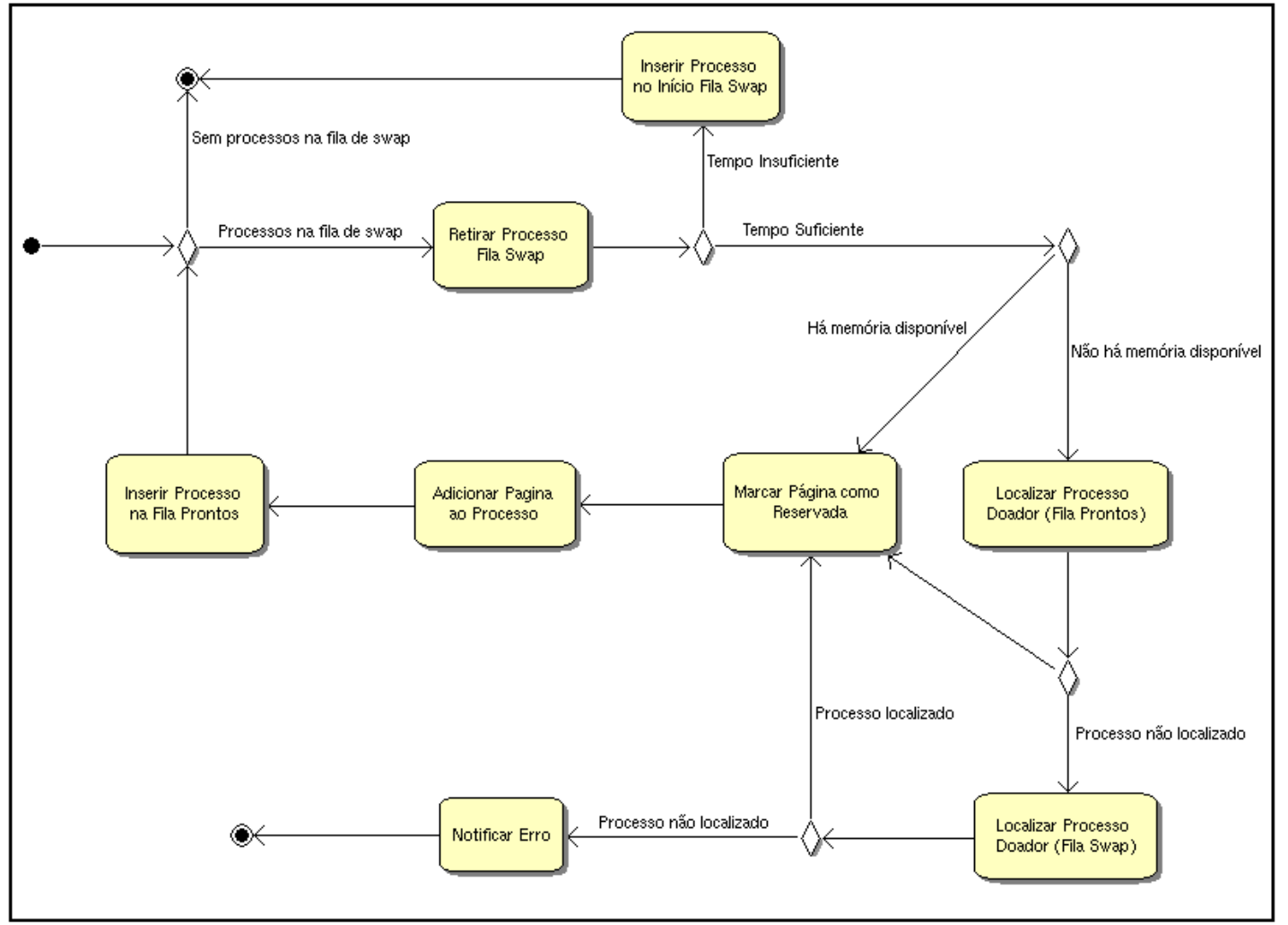

Figura 5.11: Diagrama de atividades: Verificar fila de swap.

que o mesmo reserve para si, praticamente todas as páginas existentes no nó. No entanto, o simulador desenvolvido aloca páginas apenas para o working set do processo e por este motivo não é permitido esse tipo de comportamento, pois se o working set de um processo ocupar todas as páginas existentes na máquina, ele será "morto".

Como pode ser observado, o algoritmo para tratamento de ausências de páginas utilizado é o Least Recently Used (LRU) [4]. No modelo proposto, uma página possui sua idade LRU zerada em dois momento: (1) quando é atribuída a um processo para tratar uma ausência de página e (2) ao ser utilizada por um processo durante a sua execução do quantum. Por se tratar de uma aproximação do verdadeiro algoritmo LRU, a abordagem utilizada zera o contador de idade de todas as páginas dos processos que passam pelo processador, uma vez que somente as páginas destinadas ao working set do processo são atribuídas a ele. Dessa forma, entende-se que sempre que um processo entra no processador, todas as suas páginas são utilizadas. Portanto, a página menos recentemente utilizada pertencerá ao processo que deixou o processador há mais tempo.

Após realizar o tratamento da ausência de página, sofrida pelo processo que estava no início da fila de swap, o mesmo é inserido no final da fila de prontos da $C P U$, estando assim disponível para execução. A partir desse ponto, um novo processo é retirado da fila de swap, caso exista, e a tarefa é reiniciada, até que, ou a fila esteja vazia, ou o tempo decorrido desde o momento que o processo atual ocupou o centro de serviço disco, seja 
insuficiente para o tratamento da ausência de página.

A próxima atividade a ser realizada é a verificação de chegada de processos nas máquinas. Essa atividade é relativamente simples, onde todos os processos que estão na fila de chegada do simulador e possuem tempo de chegada menor ou igual ao tempo de simulação, são retirados e inseridos na fila de prontos da máquina destino, informada no registro do arquivo de trace. Essa inserção na fila de prontos é realizada por ordem cronológica, para não causar injustiças, pois, dois métodos de chegada já foram executados antes da verificação de chegada de processos no sistema.

Antes de ser inserido na fila de prontos de uma máquina, o processo recebe o status novo, o que permitirá a outro método verificar se o processo deve, ou não, ser executado remotamente.

Um diagrama de sequência pode ser visualizado na figura 5.12, ilustrando a chegada de um processo no sistema.

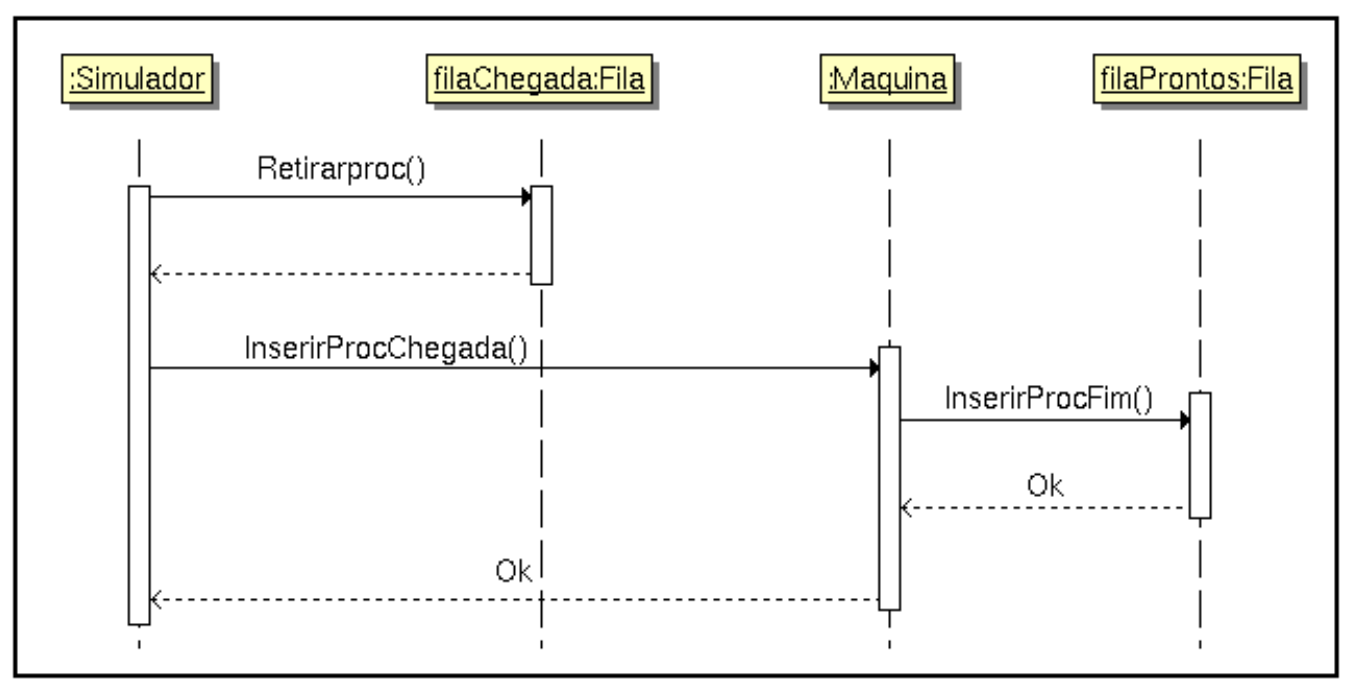

Figura 5.12: Diagrama de sequência: Verificar chegada de processos no sistema.

Finalizada a atividade anterior, o simulador irá solicitar as políticas de informação, implementadas juntamente com a classe máquinas, que realizem a atualização das informações, caso o tempo de sincronismo tenha sido atingido.

Os objetos da classe máquina replicam suas informações pertinentes ao escalonamento nas estruturas de dados do objeto carga de trabalho, que será posteriormente consultado pelas políticas de transferência e localização para tomar decisões de escalonamento.

Nesse ponto da execução do simulador, os processos que já finalizaram sua atividade de swap e de transferência, já se encontram na fila de prontos, bem como os processos submetidos pelos usuários. Também já foi realizada a atualização da carga de trabalho. Assim, é possível executar o quantum que será responsável por avançar a simulação no tempo. 
Na figura 5.13 é possível visualizar um diagrama de atividades, que ilustra os passos necessários para realizar a execução de um quantum em cada objeto máquina que constitui o sistema distribuído.

Inicialmente, o método ExecutarQuantum(), de um objeto máquina, verificará se existem processos na sua fila de prontos; caso negativo, ele registrará o quantum como tempo ocioso e finalizará. Caso contrário, o processo será retirado da fila de prontos e será verificado se o mesmo é um processo novo. Caso afirmativo, deverá ser verificado também se o processo solicitou páginas além da cota permitida pelo sistema, nesse caso, o processo será "morto", sendo enviado para a fila correspondente e o objeto máquina irá subtrair do quantum o tempo de gasto com a troca de contexto.

Caso a quantidade de páginas solicitadas pelo processo seja menor que a permitida, o objeto política de transferência receberá uma mensagem disparando o método ExecutarRemoto(), que irá informar se o processo que está sendo escalonado deve, ou não, ser enviado para execução remota em outro nó. Essa decisão é tomada após a política de transferência analisar as informações fornecidas pelo objeto carga de trabalho.

Se a decisão tomada pela política de transferência instanciada for positiva, o objeto máquina receberá como retorno o número da máquina de destino, devendo, assim, enviar o processo para execução remota no nó selecionado. No entanto, antes de realizar a transferência pela rede, será necessário ajustar o tempo de processamento do processo de acordo com a velocidade do novo processador. Isto se faz necessário pois o tempo de processamento deixa de ser tratado em MIPS, quando o processo é importado do arquivo de trace. Assim, o tempo de execução desse processo pode variar de uma máquina para outra, dependendo da velocidade do processador de cada uma. Essa medida não se faz necessária em plataformas homogêneas.

Um diagrama de seqüência que trata a execução remota pode ser visualizado na figura 5.14. Esse diagrama destaca a participação do computador de destino, que recebe o processo enviado remotamente e o insere na fila de processos que estão sendo transferidos, de onde será posteriormente retirado pela atividade "verificar chegada transferência" conforme descrito anteriormente.

Caso a política de transferência opte pela execução local, o processo cujo status seja igual a novo, irá alocar páginas de memória para poder iniciar sua execução. Desse ponto em diante, o processo deixa de possuir esse status e passa a ter o status pronto, iniciando o conjunto de atividades executadas também por aqueles processos que já haviam sido inicializados em quanta anteriores.

A verificação do tempo da próxima ausência de páginas é o primeiro passo a ser executado nessa linha de atividades, que somente poderá ocorrer caso a quantidade de páginas alocadas ao processo seja menor que a quantidade de páginas necessárias para 


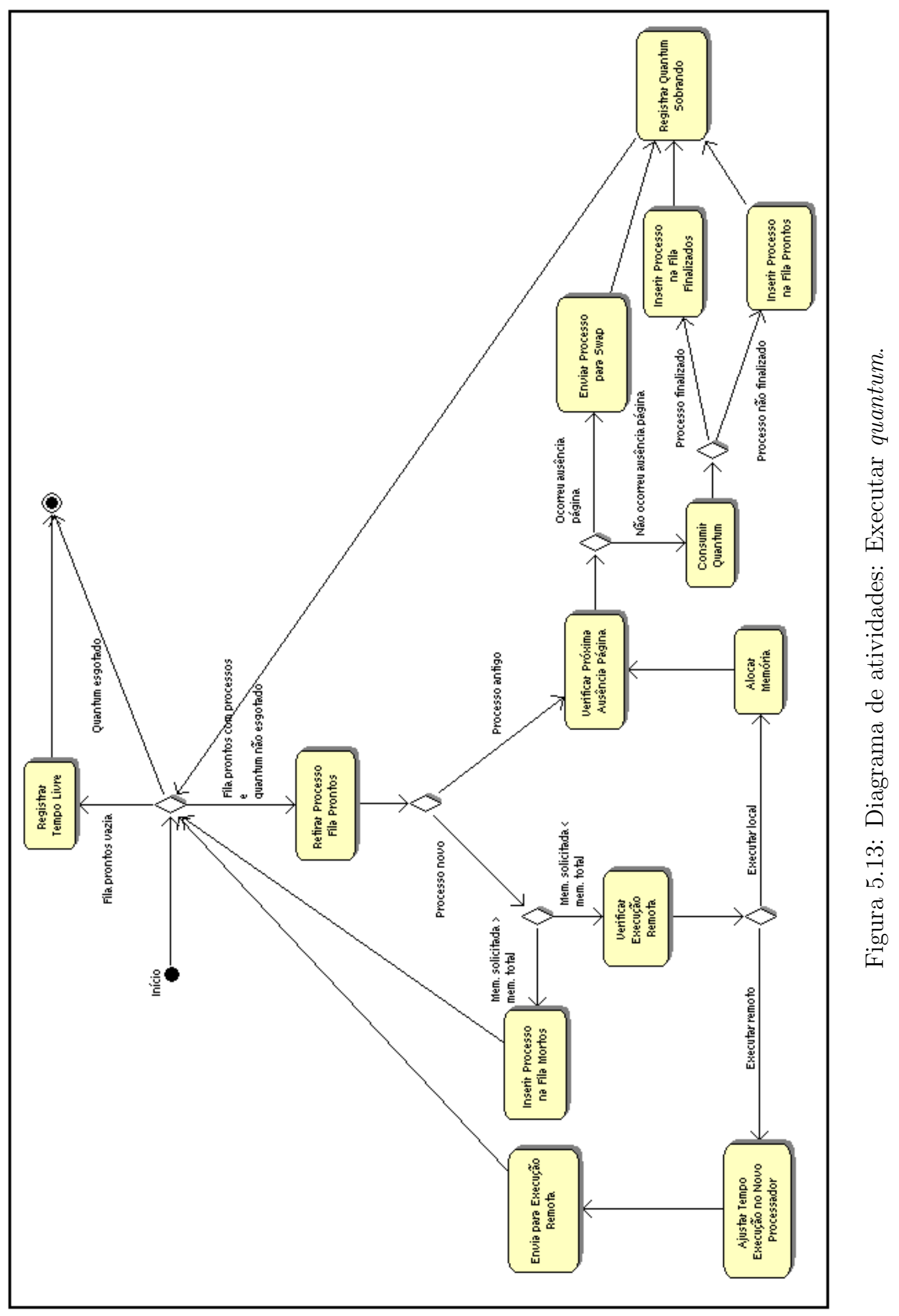




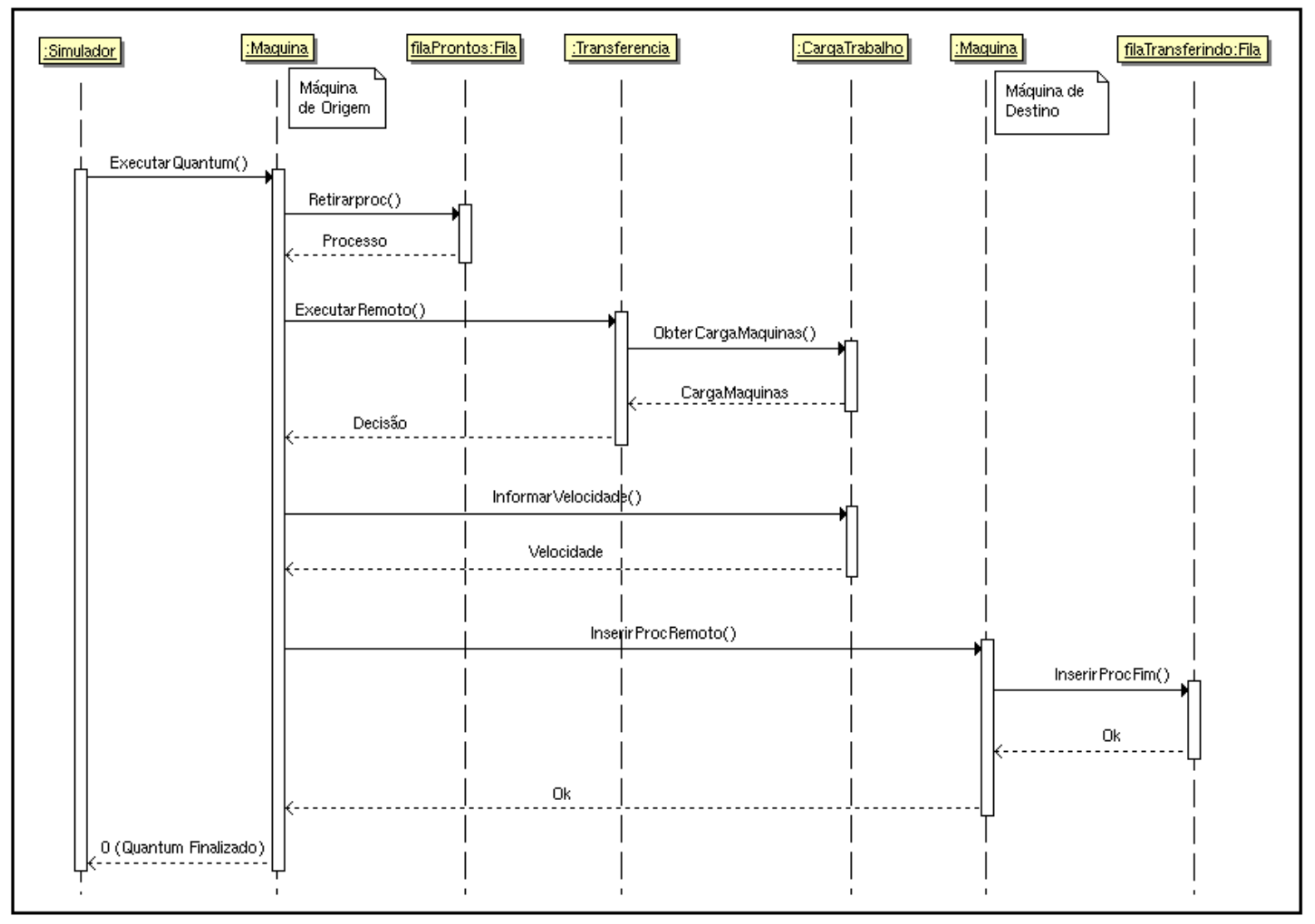

Figura 5.14: Diagrama de sequência: Executar remoto.

armazenar o seu working set. A fórmula utilizada para calcular o instante da próxima ausência de página é aquela apresentada em 5.1.

Caso o tempo da próxima ausência de página seja menor que o tempo atual, mais o quantum restante para a execução do processo e menor, também, que o tempo atual acrescido do tempo necessário para finalizar o processo, uma ausência de página terá ocorrido. Dessa forma, o objeto máquina incrementará o contador de ausências de páginas ocorridas e enviará o processo para o disco, registrando o tempo de simulação em que o evento ocorreu. Após enviar o processo para a fila de swap, o objeto calculará o quantum restante e retornará para a condição inicial do método ExecutarQuantum(), onde um novo processo será selecionado para consumir o quantum restante, caso haja algum processo na fila de prontos.

Porém, se não ocorrer ausência de página e o tempo necessário para finalizar a execução do processo for menor que o quantum disponível, esse processo será finalizado, tendo o seu status alterado e será inserido na fila de finalizados, permitindo que outro processo seja escalonado, caso existam processos na fila de prontos. No entanto, se o quantum disponível não for suficiente para finalizar a execução do processo, o mesmo irá consumir todo o quantum e ao término deste, o processo será enviado para o final da fila de prontos, finalizando o método ExecutarQuantum(), retornando o controle para o objeto simulador. 
Ao retomar o controle, o objeto simulador executará, em todos os nós do sistema, o evento AcrescentarTempoLRU(), sendo este responsável por aumentar em uma unidade a idade LRU presente em todos os processos ativos, ou seja, aqueles armazenados nas filas de prontos e de swap.

A última atividade a ser executada é a verificação da necessidade de realizar uma migração; caso não haja necessidade, um ciclo estará completado, iniciando um novo ciclo de atividades caso exista pelo menos um processo no sistema, seja na fila de chegada do objeto simulador ou nas filas: (1) prontos, (2) swap e (3) transferindo de um dos objetos "maquina" instanciado.

Na figura 5.15 tem-se um diagrama de sequência que descreve o processo de migração, caso ela seja necessária.

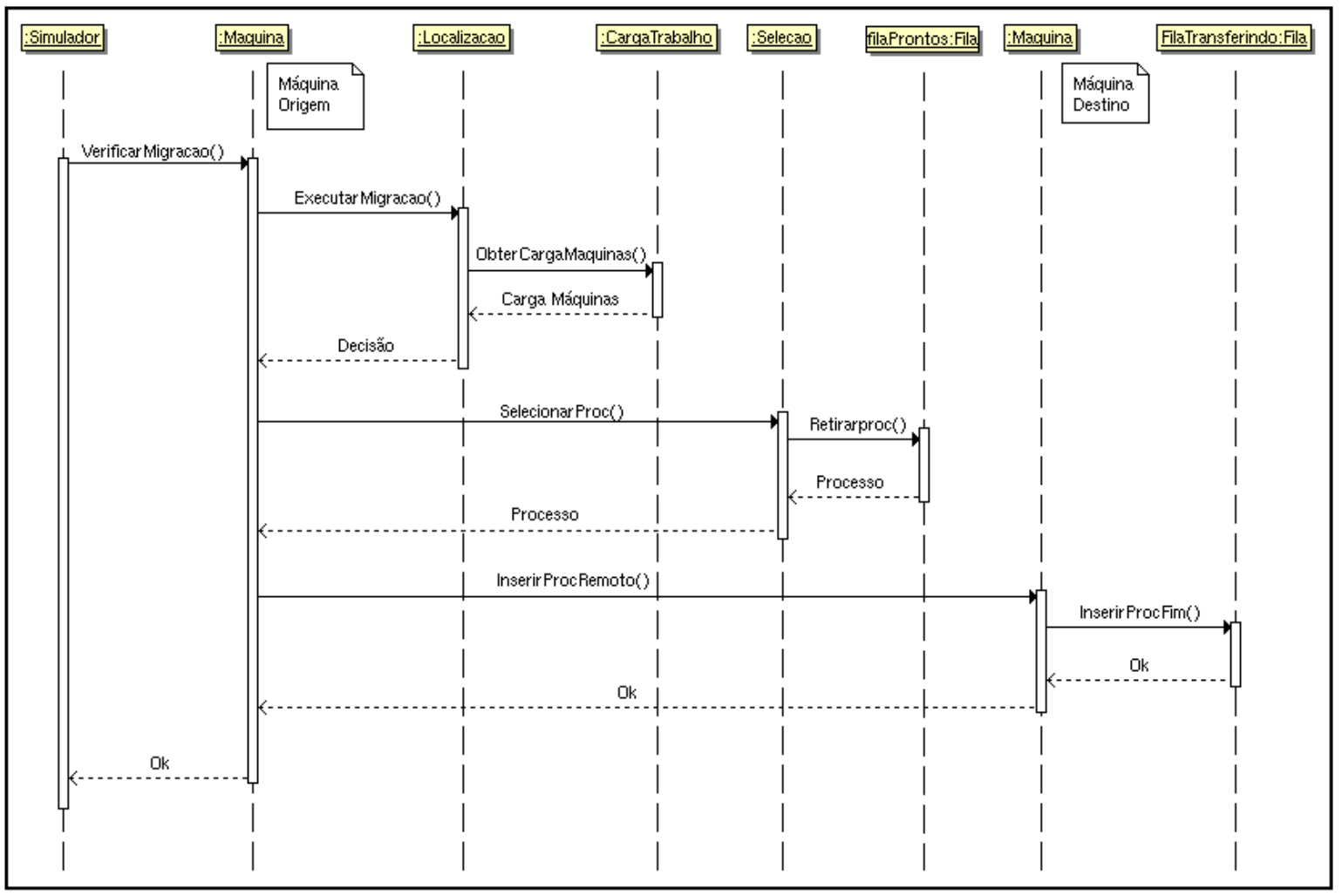

Figura 5.15: Diagrama de sequência: Executar migração.

Na figura 5.15 percebe-se que a decisão de realizar uma migração de processos é tomada pelo objeto "localizacao", através da chamada ExecutarMigracao() que, após verificar a carga de trabalho do sistema, retornará uma confirmação para o objeto que o chamou. Sendo assim, uma chamada do tipo SelecionarProc() será executada para que um processo seja selecionado para migração, sendo retirado da fila de prontos da máquina de origem. Não é possível retirar processos que estejam tratando ausências de páginas e/ou que estejam sendo recebidos pela rede.

Após selecionar o processo a ser migrado, a máquina de origem solicita à máquina 
de destino que receba o processo para migração. Esta, por sua vez, insere o processo na fila transferindo, que será posteriormente enviado para a fila de prontos, após consumir o tempo necessário no centro de serviço rede.

Ao finalizar a execução de todos os processos que chegaram no sistema e não foram mortos, o arquivo de relatório é escrito e a simulação é finalizada, emitindo um aviso ao usuário.

\subsection{Considerações finais}

Para avaliar as políticas propostas foi utilizada modelagem por redes de filas, considerando como centros de serviço o processador, a rede de comunicação e o disco. Já os processos são tratados como tokens, que são enviados aos centros de serviços.

O sistema modelado representa um cluster de computadores utilizando sistema de imagem única, fazendo uso do escalonamento descentralizado e dinâmico, onde as aplicações são escalonadas no momento de sua submissão ao sistema. Para tal, as políticas de transferência avaliadas não possuem conhecimento prévio dos recursos que serão requeridos pelos processos.

Para resolver esse modelo, foi utilizado simulação baseada em trace, obtido em [38] e adaptado de acordo com [6]. Esses traces possuem as informações: (1) tempo de chegada do processo, (2) nó de destino, (3) tempo de processamento, (4) quantidade de memória necessária para o processo e (4) o nome do processo.

O simulador utilizado foi desenvolvido baseado naquele apresentado em [34] e utilizado em [6] e [33]. Esse novo simulador contempla configurações mais abrangentes, possuindo uma grande quantidade de parâmetros de entrada e apresentando relatórios mais detalhados, além de incluir novas funcionalidades ausentes no simulador utilizado como referência. Além disso, algumas características foram melhoradas, como o algortimo de substituição de página LRU.

Com o objetivo de documentar esse novo produto, modelou-se o software utilizando UML, apresentando as visões (1) de caso de uso, (2) estrutural e (3) comportamental, através de diagramas apropriados. Esse simulador foi desenvolvido de maneira modular e genérica. Isso permite simular outros modelos, como aqueles que utilizam escalonamento centralizado, uma vez que no arquivo de configuração é possível fornecer as configurações de cada nó do sistema.

A partir desse ponto já torna-se possível apresentar as políticas desenvolvidas e avaliálas perante políticas encontradas na literatura. Assim, esse será o assunto do próximo capítulo. 


\section{Capítulo \\ 6 \\ Políticas}

\subsection{Considerações iniciais}

Uma das abordagens existentes para a distribuição de processos aos elementos de processamento é denominada execução remota. Nesta abordagem, quando um processo é submetido a um nó do cluster, a política de transferência é acionada para decidir se esse processo será executado localmente ou se deverá ser enviado para execução remota em um outro nó.

Uma segunda abordagem é realizada através de migração de processos, onde um processo pode ser suspenso, a qualquer momento, e enviado para uma máquina remota para finalizar seu processamento.

Todavia, em [6] foi obsevado que para aplicações do tipo memory-intensive, a abordagem utilizando execução remota é mais eficiente. Dessa forma, este capítulo propõe três novas políticas de escalonamento, tendo como foco as aplicações memory-intensive, utilizando execução remota para distribuir processos.

Essas políticas foram comparadas com outras encontradas tradicionais, que utilizam informações de CPU e de memória. Várias políticas, utilizando índices unitários de CPU e memória, foram encontradas na literatura, sendo assim, foi realizada uma comparação entre elas, selecionando as mais eficientes para servirem de parâmetros para as análises das políticas propostas. 


\subsection{Cargas de trabalho}

A avaliação das políticas desenvolvidas será realizada através de simulações baseadas em traces. Os arquivos utilizados neste trabalho são os mesmos disponibilizados por [34] e utilizados em [6] e [33]. Esses arquivos foram disponibilizados originalmente no repositório Parallel Workloads Archive, onde muitos arquivos de traces são avaliados e disponibilizados por Dror Feitelson da universidade Hebrew [38].

Em particular, os traces utilizados neste trabalho foram disponibilizados pelo Los Alamos National $\mathrm{Lab}^{1}$, totalizando quatro meses de coletas em um sistema de 1024 nós. Os registros de aplicações parelelas foram convertidos para tarefas seqüenciais, para melhor caracterizar aplicações destinadas a sistemas distribuídos de imagem única. Como tempo de chegada foi adotado o momento da submissão do processo pai e como tempo de processamento foi considerado o total de tempo gasto pelo processo pai e seus filhos [6].

Esses arquivos contêm os campos mencionados no capítulo 5, assim, as entradas momento de submissão, nó de destino, tempo de processamento e nome da aplicação, foram retirados dos arquivos originais. Já a quantidade de memória utilizada, foi gerada através da distribuição de Pareto, já que esta distribuição é a que melhor descreve o comportamento da quantidade de memória utilizada por aplicações [37] e [34]. A funcão utilizada para gerar os valores da distribuição de Pareto foi obitida em [39]. A função para geração de números pseudo-aleatórios foi obtida em [40].

As cargas de trabalho empregadas nas simulações são destinadas a um sistema de clusters com seis nós, cujos resultados podem facilmente ser expandidos para um sistema com uma maior quantidade de nós. A decisão de trabalhar com seis máquinas na composição do cluster foi determinada por vários motivos, destacando-se:

- Manter compatibilidade com os trabalhos realizados anteriormente, uma vez que são utilizados os traces disponibilizados originalmente em [34];

- A alteração apenas da quantidade de memória utilizada permite uma melhor avaliação dos resultados, pois é o único fator que será alterado se comparado aos traces originais, cujos trabalhos de referências foram baseados;

- A simulação utilizando um cluster de tamanho médio apresenta um grau maior de facilidade no rastreamento e na observação da tarefa de escalonamento

A função de distribuição de Pareto utiliza três valores como entradas para gerar a quantidade de memória utilizada pelas aplicações. O primeiro valor, denominado $k$, de-

\footnotetext{
${ }^{1}$ Os traces adaptados podem ser encontrados em http://www.cse.ohio-state.edu/hpcs/
} 
termina o menor valor a ser gerado. O valor $p$ determina o valor máximo a ser gerado e o $\alpha$ define o peso da "cauda" da distribuição.

Através desses valores foram determinados dois limites de utilização de memória. O primeiro intervalo possui três valores diferentes de $\alpha$ e o segundo apenas dois. Desta forma, são definidos cinco configurações de utilização de memória para os processos contidos nos arquivos de trace.

O primeiro intervalo de dados utilizado possui $64 \mathrm{MB}$ como limite mínimo e $256 \mathrm{MB}$ para o máximo. Os valores de $\alpha$ utilizados foram 5, 1 e 0,2. Esses valores foram definidos, pois, ao se utilizar $\alpha=5$, há o predominância de aplicações $C P U$-bound, com uma pequena concentração de aplicações memory-itensive; conforme o valor de alfa diminui, obtém-se cargas mistas entre aplicações de ambas as categorias. Ao se utilizar $\alpha=1$ tem-se uma maior concentração de aplicações memory-intensive, porém, com uma quantidade considerável de aplicações $C P U$-bound; já com $\alpha=0,2$ há o predomínio de aplicações memory-itensive, porém, com baixa utilização de memória, uma vez que o limite inferior é de $64 \mathrm{MB}$.

O gráfico na figura 6.1 apresenta a porcentagem de memória utilizada pelas aplicações para o intervalo de $64 \mathrm{MB}$ a $256 \mathrm{MB}$, caracterizando as distribuições de Pareto para os valores de $k, p$ e $\alpha$ descritos anteriormente.

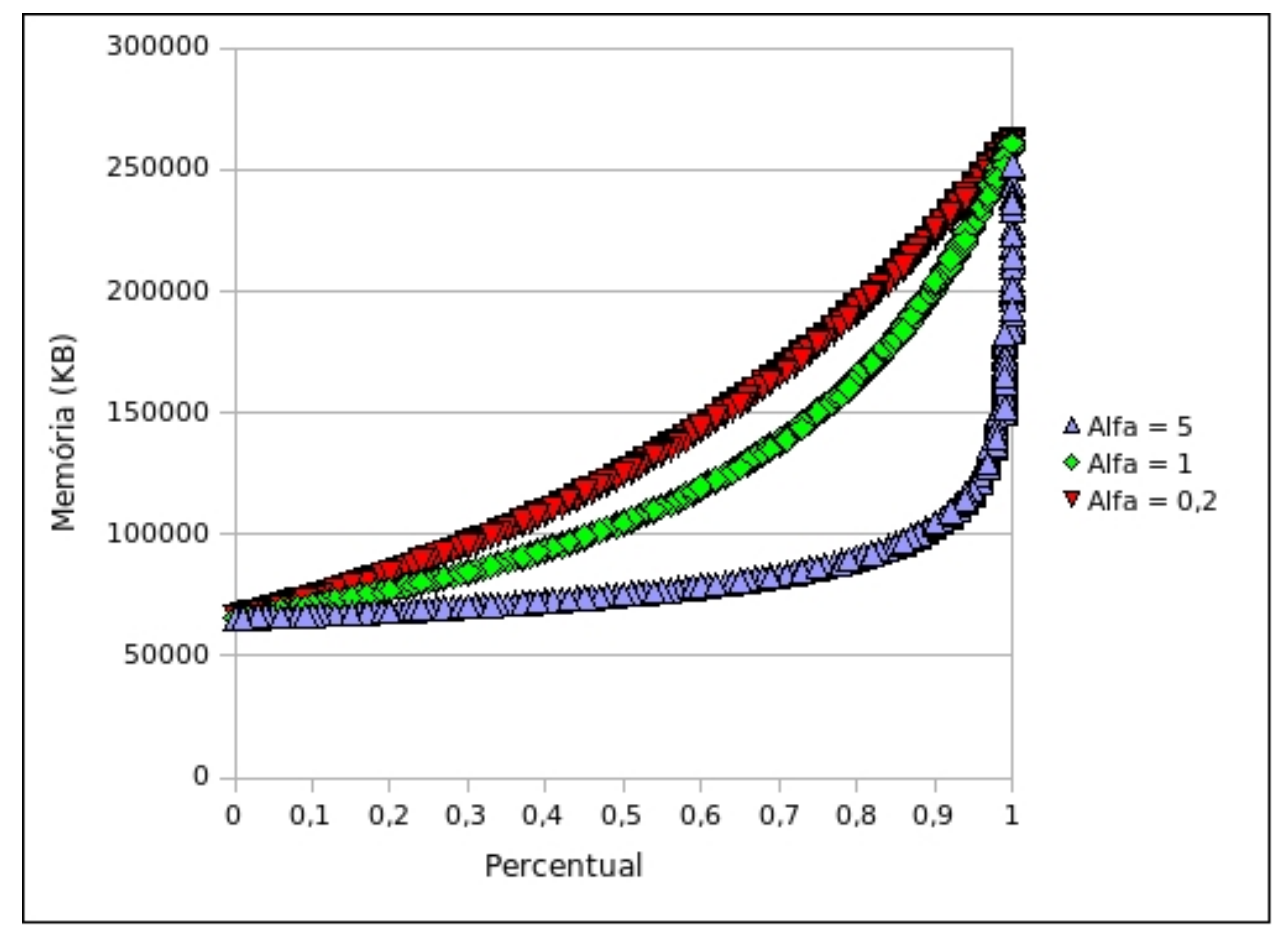

Figura 6.1: Distribuição da quantidade de memória, com variação entre 64 MB e 256 MB.

Através do gráfico da figura 6.1, percebe-se que ao utilizar $\alpha=5$, aproximadamente $65 \%$ das aplicações requisitam menos de $80 \mathrm{MB}$ de memória, facilitando o balanceamento 
da memória, pois, nessa configuração poucas ausências de páginas serão geradas. À medida que os valores de $\alpha$ são reduzidos, o percentual de aplicações que requisitam menos de $80 \mathrm{MB}$ de memória passam de aproximadamente $20 \%$ para $\alpha=1 \mathrm{e}, 15 \%$ para $\alpha=0,2$.

Porém, em $\alpha=1$, aproximadamente $70 \%$ das aplicações requisitam menos de 140 $\mathrm{MB}$, contra aproximadamente $55 \%$ quando $\alpha=0,2$.

É possível perceber também que o peso da "cauda" da distribuição aumenta à medida que o valor de $\alpha$ diminui, indicando um aumento considerável da utilização de memória, permitindo caracterizar a transição entre aplicações $C P U$-bound e memory-intensive com o limite inferior pequeno de memória requisitada.

Esse comportamento é confirmado pelos gráficos da figura 6.2, que demonstram o espalhamento dos valores gerados para os diferentes valores de $\alpha$.
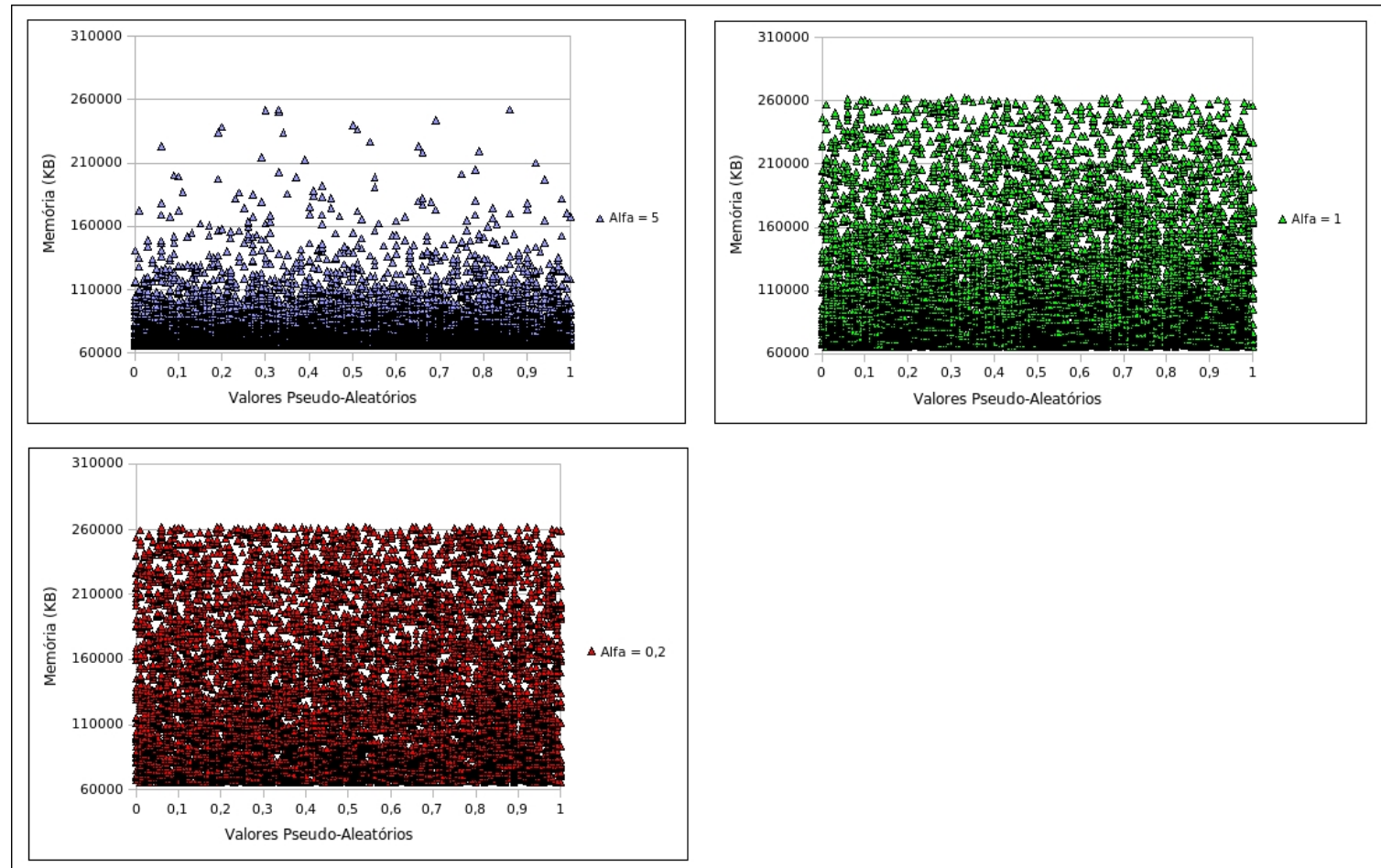

Figura 6.2: Espalhamento das quantidades de memórias geradas para o intervalo entre 64 MB e $256 \mathrm{MB}$, com $\alpha=5, \alpha=1$ e $\alpha=0,2$, respectivamente.

Através do primeiro gráfico, observa-se que a grande maioria dos pontos encontram-se próximos do limite inferior de $64 \mathrm{MB}$, com uma pequna quantidade chegando ao limite superior de 256 MB. Essa situação não ocorre na segunda situação, onde $\alpha=1$, cuja concentração de pontos próximo ao limite superior apresenta-se em maior concentração. No terceiro gráfico com $\alpha=0,2$, os pontos estão distribuídos de maneira mais uniforme pelo espaço de variação de memória.

O segundo intervalo é definido pelos valores de $k$ e $p$, apresentando variação entre 128 e 256 MB. O valor máximo foi mantido, pois inicialmente a quantidade de memória 
destinadas a cada nó do cluster é de 512 MB. Assim, uma aplicação poderá utilizar 50\% dessa quantidade, o que representa bons exemplos de aplicações memory-intensive.

A quantidade máxima de memória requisitada foi mantida, pois, configurando-se $p>256$, possibilitando que as aplicações solicitem quantidades acima de $50 \%$ do valor inicial de memória disponível para cada máquina, percebe-se que as políticas tradicionais permitem que o sistema entre em trashing rapidamente e que a proporção dos resultados são mantidos, descartando a necessidade de se caracterizar esse tipo de carga.

A figura 6.3 demonstra a distribuição gerada para o segundo intervalo de valores definido anteriormente. Os valores atribuídos a $\alpha$ são 5 e 0,2 , desconsiderando o valor 1 atribuido na configuração anterior. Esta decisão foi tomada pois, ao se utilizar um valor grande para a quantidade mínima de memória, neste caso $128 \mathrm{MB}$, os resultados obtidos com $\alpha=1$ e $\alpha=0,2$ apresentam as mesmas características, pois os pesos das "caudas" gerados são próximos. Nessa configuração de limites, todas as aplicações podem ser classificadas como memory-intensive.

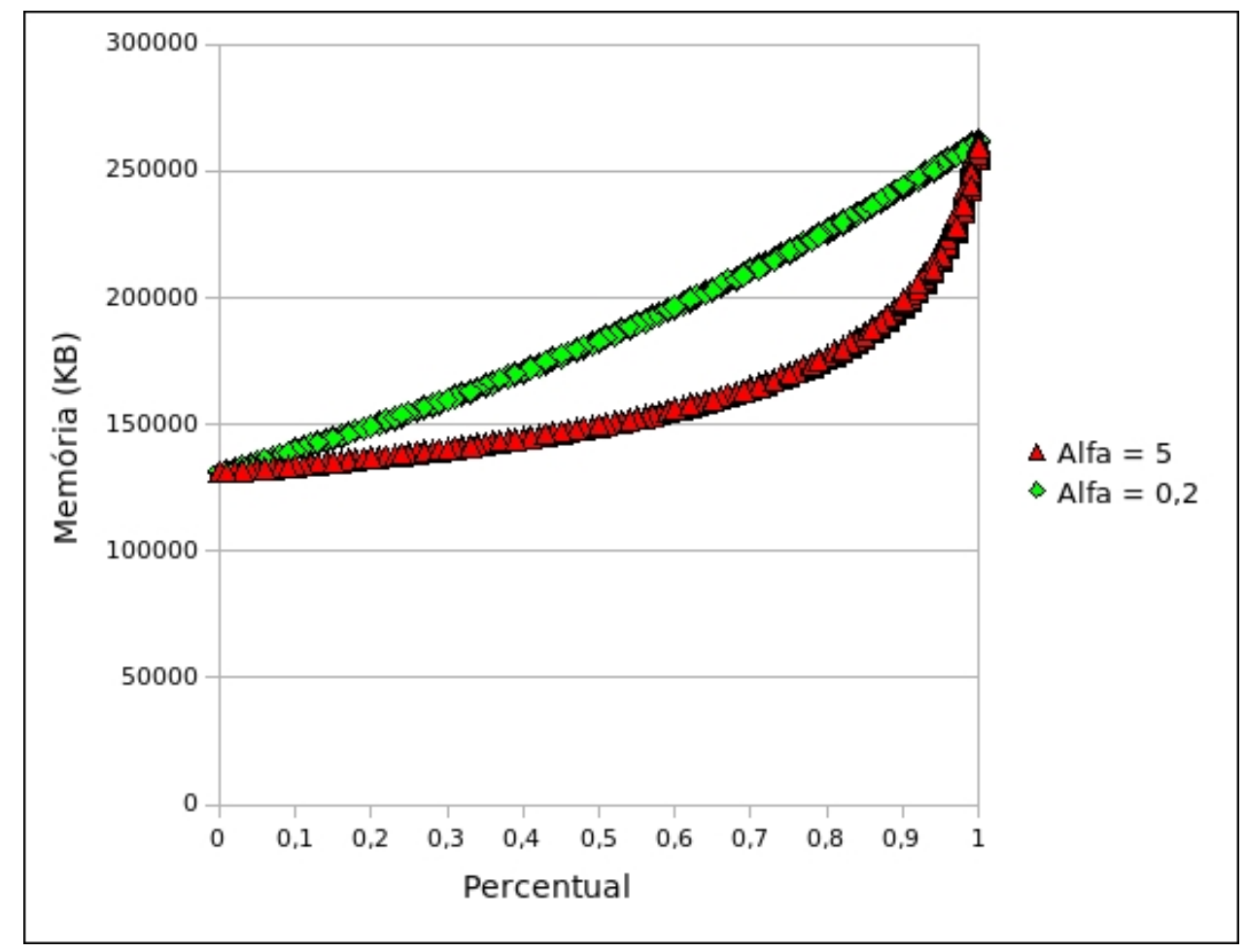

Figura 6.3: Distribuição da quantidade de memória solicita pelas aplicações, com limites inferior e superior definidos em $128 \mathrm{MB}$ e $256 \mathrm{MB}$, respectivamente.

Ao utilizar-se $\alpha=5$, pretende-se simular um ambiente em que a quantidade de memória, requisitada pela maioria dos processos, não sobrecarregue o ambiente. Ao contrário, ao utilizar $\alpha=0,2$, pretende-se impor, ao sistema, uma sobrecarga da quantidade de memória requisitada.

Assim, como no caso anterior, à medida que o valor de $\alpha$ decresce, aumenta o peso da 
"cauda" da distribuição de Pareto, aumentando a demanda de memória solicitada pelas aplicações. Isto pode ser comprovado, por exemplo, ao observar que aproximadamente $70 \%$ das aplicações solicitam menos de 160 MB de memória para a primeira configuração de $\alpha$, enquanto que para a segunda configuração, menos de $30 \%$ das aplicações solicitam essa mesma quantidade de memória DRAM.

Através da figura 6.4 percebe-se que ao utilizar $\alpha=5$, a maioria das aplicações requisitam uma quantidade de memória DRAM próxima ao limite inferior de $128 \mathrm{MB}$, o que não ocorre com $\alpha=0,2$, cujas solicitações estão distribuídas de maneira mais uniforme por todo o espaço amostral.
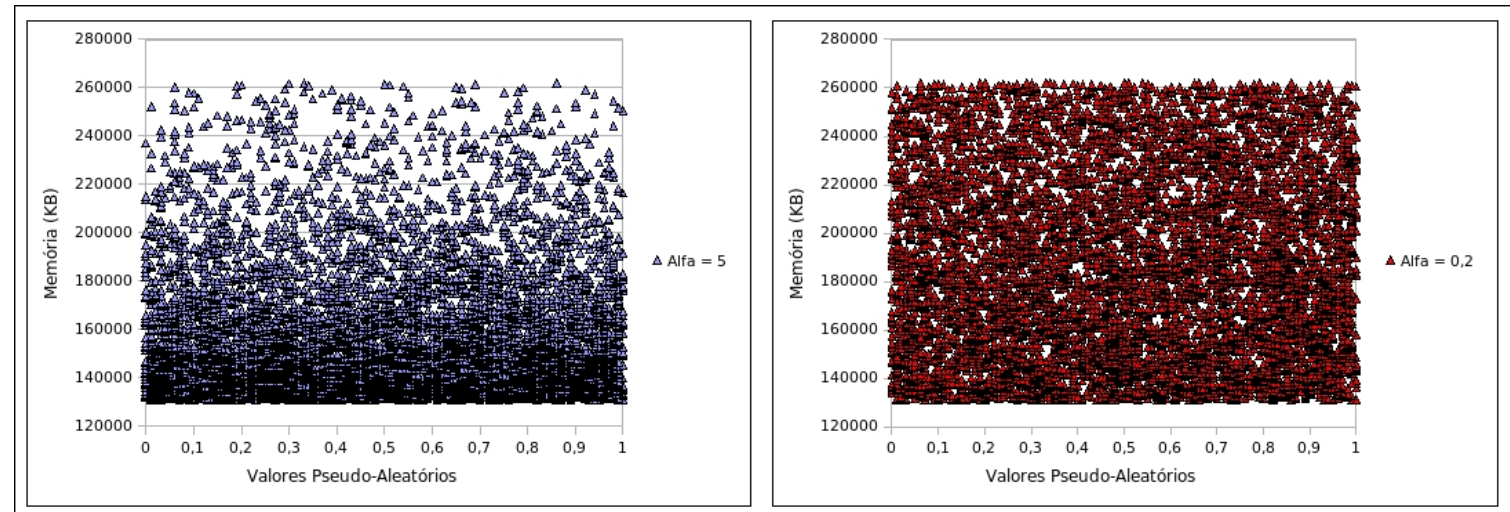

Figura 6.4: Espalhamento das quantidades de memórias geradas para o intervalo entre $128 \mathrm{MB}$ e $256 \mathrm{MB}, \operatorname{com} \alpha=5$ e $\alpha=0,2$, respectivamente.

A tabela 6.1 apresenta um resumo das variações de memória utilizadas nas simulações e apresenta uma síntese do tipo de carga que se espera obter com essas combinações. Isso permite observar que, para cada tipo de carga foi atribuída uma letra entre "A" e "E", que será adotada deste ponto em diante.

\begin{tabular}{|c|c|c|c|}
\hline Intervalo de memória & $\alpha$ & Denominação & Característica da carga \\
\hline \multirow{2}{*}{$\begin{array}{c}64 \mathrm{MB} \\
\mathrm{e}\end{array}$} & 5 & $\mathrm{~A}$ & Aplicações predominantementes CPU-bound \\
\cline { 2 - 4 } $256 \mathrm{MB}$ & 1 & $\mathrm{~B}$ & $\begin{array}{c}\text { Transição entre aplicações CPU-bound } \\
\text { e memory-itensive com pouca carga }\end{array}$ \\
\cline { 2 - 4 } & 0,2 & $\mathrm{C}$ & $\begin{array}{c}\text { Aplicações predominantementes } \\
\text { memory-intensive com pouca carga }\end{array}$ \\
\hline $128 \mathrm{MB}$ e & 5 & $\mathrm{D}$ & Aplicações memory-intensive com carga moderada \\
\cline { 2 - 4 } $256 \mathrm{MB}$ & 0,2 & $\mathrm{E}$ & Aplicações memory-intensive com carga alta \\
\hline
\end{tabular}

Tabela 6.1: Caracterização das cargas utilizadas nas simulações. 


\subsection{Plataformas utilizadas}

Uma vez que as cargas a serem submetidas nas simulações foram definidas, deve-se definir as plataformas que serão utilizadas para a submissão dessas cargas de trabalho.

A primeira plataforma analisada, denominada "Plataforma 1", é composta de máquinas homogêneas, com as seguintes configurações:

- Velocidade de processamento: 1000 MIPS;

- Quantidade de memória DRAM: 512 MB;

- Tempo necessário para tratamento de uma ausência página: 10 ms;

- Taxa de transmissão das interfaces de rede: 100 Mbps;

- Custo para realizar uma execução remota: 100 ms.

Para todas as plataformas definidas, o working set das aplicações será de $60 \%$ e o custo para a troca de contexto será de $0,1 \mathrm{~ms}$. O tempo de sincronização inicialmente atribuído será de $1 \mathrm{~ms}$, uma vez que o sistema a ser simulado é composto por duas redes: uma para submissão de processos pelos usuários e, também, para envio e recebimento de processos através das execuções remotas; e a segunda para realizar a sincronização das informações pela política de informação.

A topologia lógica dessa organização pode ser visualizada na figura 6.5.

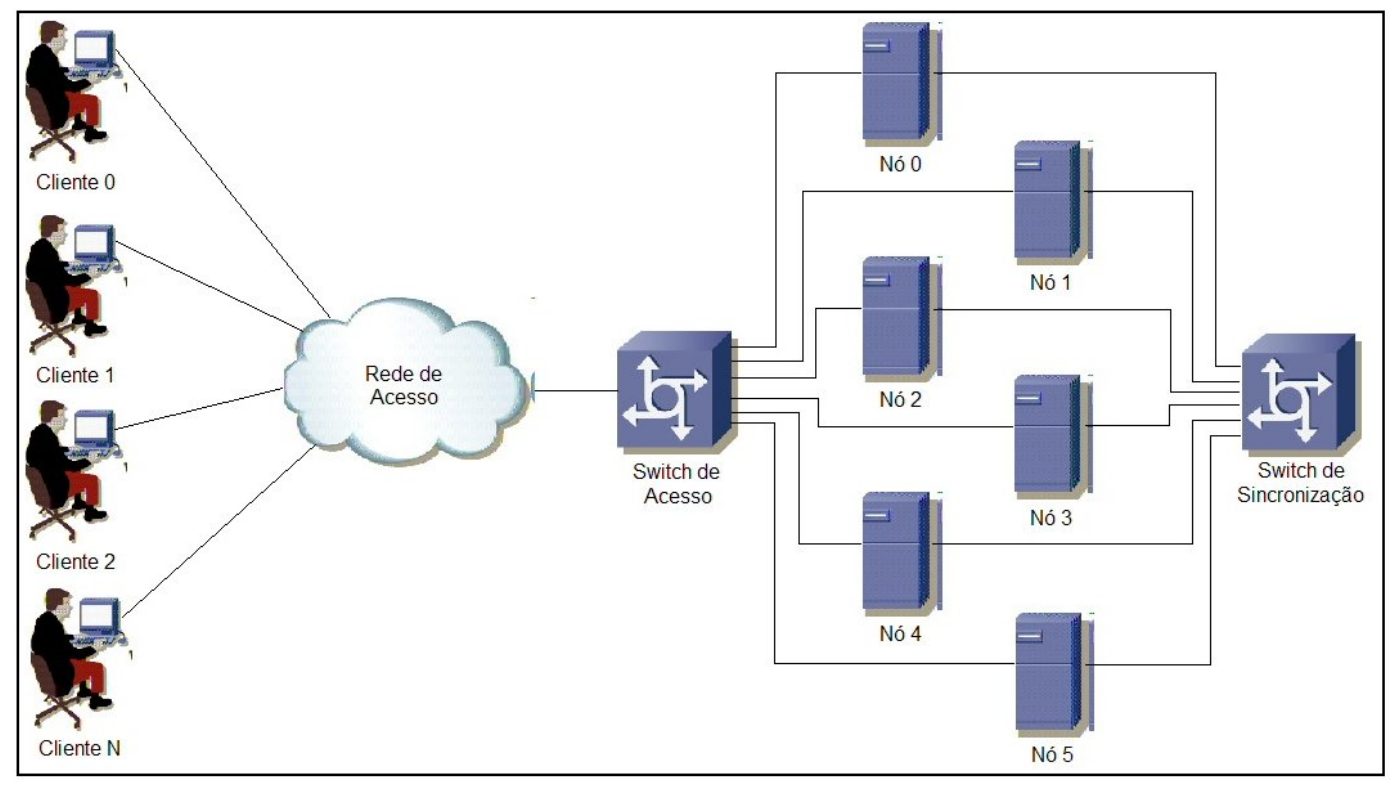

Figura 6.5: Topologia lógica do cluster simulado. 
Analisando essa topologia, observa-se que a sincronização das informações pode ser realizada constantemente, com intervalos de tempo em torno de $1,6 * 10^{5} \mathrm{seg}$. por máquina do cluster, apresentando uma taxa de sincronismo muito menor que a definida.

Alguns produtos como o OpenSSI já estão preparados para dar suporte a esse tipo de topologia, visto que os preços das interfaces de redes e dos switches genéricos estão reduzindo muito nos últimos anos. Por esses e outros motivos optou-se por utilizar essa mesma configuração neste trabalho, destacando mais uma característica do simulador.

A fim de analisar o impacto de algumas heterogeneidades configuracionais ${ }^{2}$, outras plataformas foram analisadas.

A plataforma, denominada "Plataforma 2", apresenta heterogeneidade de CPU. As demais característica são iguais às apresentadas na Plataforma 1. Na tabela 6.2 são apresentadas as variações das velocidades dos processadores.

\begin{tabular}{|c|c|}
\hline Nó & Velocidade processador (MIPS) \\
\hline 0 & 500 \\
\hline 1 & 1000 \\
\hline 2 & 2000 \\
\hline 3 & 500 \\
\hline 4 & 1500 \\
\hline 5 & 500 \\
\hline
\end{tabular}

Tabela 6.2: Velocidades dos processadores da "Plataforma 2".

Através da tabela 6.2 é possível observar que o poder de processamento total da "Plataforma 2" foi mantido igual ao da "Plataforma 1", permitindo verificar o impacto causado pela variação nas velocidades e não pela potência computacional da plataforma.

A terceira plataforma, denominada "Plataforma 3", apresenta heterogeneidade de memória. Entretanto, a capacidade de armazenamento total da plataforma foi ampliada, uma vez que ao submeter a mesma carga na plataforma com heterogeneidade de memória, mas com a mesma capacidade de armazenamento, praticamente todas as políticas permitiram que o sistema entrasse em estado de trashing.

A tabela 6.3 apresenta a quantidade de memória adotada para cada nó do cluster.

A quarta e última plataforma, denominada "Plataforma 4", apresenta heterogeneidade de disco, obtida através da variação do tempo de tratamento das ausências de páginas.

A tabela 6.4 apresenta as velocidades adotadas para o tratamento de uma ausência de página em cada nó. Cada máquina do sistema é composta por apenas um dispositivo de disco rígido. Para situações em que há uso de Redundant Array of Independent Disks (RAID) é necessário calcular o tempo de tratamento de uma ausência de página utilizando-

\footnotetext{
${ }^{2}$ Citadas apenas como heterogeneidade deste ponto em diante
} 


\begin{tabular}{|c|c|}
\hline Nó & Quantidade de memória disponível (MB) \\
\hline 0 & 512 \\
\hline 1 & 1024 \\
\hline 2 & 2048 \\
\hline 3 & 512 \\
\hline 4 & 1536 \\
\hline 5 & 384 \\
\hline
\end{tabular}

Tabela 6.3: Quantidade de memória DRAM atribuída aos nós da "Plataforma 3".

se esse mecanismo. Porém, esse arranjo de discos pode ser facilmente considerado pelo simulador desenvolvido, uma vez que este utiliza uma abstração do dispositivo disco, não retratando o comportamento físico do mesmo.

\begin{tabular}{|c|c|}
\hline Nó & $\begin{array}{c}\text { tempo de tratamento de uma } \\
\text { ausência de página (ms) }\end{array}$ \\
\hline 0 & 30 \\
\hline 1 & 20 \\
\hline 2 & 10 \\
\hline 3 & 20 \\
\hline 4 & 10 \\
\hline 5 & 30 \\
\hline
\end{tabular}

Tabela 6.4: Tempo necessário para realizar o tratamento de uma ausência de página na "Plataforma 4".

Ao somarem-se os tempos para tratamento das ausências de páginas em cada máquina, tem-se o total de $120 \mathrm{~ms}$, ao invés dos $60 \mathrm{~ms}$ obtidos na "Plataforma 1". Isso ocorre por que os discos da "Plataforma 1" retratam a situação dos discos encontrados no mercado, em que o tempo de tratamento de uma ausência de página é de aproximadamente $10 \mathrm{~ms}$ [33].

Por esse motivo, ao realizar-se o estudo na "Plataforma 4", uma nova simulação foi contemplada com a "Plataforma 1", utilizando-se discos com tempo de tratamento de uma ausência de página de $20 \mathrm{~ms}$, totalizando os $120 \mathrm{~ms}$ apresentados na "Plataforma 4".

Uma última observação precisa ser feita antes da apresentação das políticas e da análise dos resultados das simulações. A média de ausências de páginas utilizada em todas as plataformas é de 10 ausências para cada um milhão de instruções executadas, caso a quantidade de memória solicitada pelo working set do processo seja menor que a quantidade de memória disponível para ele.

Esse valor é bastante conservador, pois, causa a maior quantidade de ausência de páginas presenciada em uma plataforma real, já que os valores reais obtidos através de instrumentação do kernel, variam entre um e dez, conforme discutido no capítulo 5.

Durante as simulações o valor $\sigma$, definido em 5.1, poderia ser variado, seguindo o 
método empregado em [34] e [6], no entanto, a variação da quantidade de ausências de páginas sofridas pelas aplicações é ocasionada pela variação dos valores de $k, p$ e $\alpha$. Assim, os resultados obtidos com a variação de $\sigma$ são semelhantes aos obtidos com a variação dos parâmetros da função de distribuição de Pareto, empregado neste trabalho. Isso permite afirmar que manter o valor de $\sigma$ no valor máximo é uma medida bastante conservadora.

\subsection{Políticas de referência}

Para avaliar as políticas propostas é necessário utilizar políticas conhecidas na literatura, utilizando-as como referência. Assim, serão selecionadas duas políticas descritas na literatura. Uma das políticas utilizará informações da CPU para realizar o balanceamento e a segunda utilizará informações de memória.

Assim como em [37], [34], [6] e [33], a eficiência das políticas foi medida através da perda de desempenho. Esta medida é calculada através da equação 6.1.

$$
\frac{\text { Tempo Total }}{\text { Tempo de Execução dos Processos }}
$$

Na literatura, tanto para índices de CPU, quanto de memória, foram encontradas políticas que tomam decisões de escalonamento através de comparações, bem como através de limites, como descrito no capítulo 3. Dessa forma, inicialmente será feita uma comparação dessas abordagens, para as políticas de referência, a fim de determinar quais as melhores para serem utilizadas nas análises das novas políticas.

\subsubsection{Políticas baseadas em $C P U$}

Na literatura são encontrados muitos índices de $C P U$, entretanto, as políticas mais eficientes utilizam o tamanho da fila de prontos para realizar o escalonamento, uma vez que essa medida reflete diretamente a carga do nó no momento da sincronização, realizada pela política de informação [6].

Como mencionado no início desta seção, três abordagem são adotadas atualmente, uma delas baseada em comparação e outras duas baseadas em limites. A primeira política denominada "CPU-total" realiza o balanceamento total da carga submetida à plataforma, podendo ser definida de acordo com o agoritmo 6.1. 
para cada Nó do cluster faça

| Procurar o nó com a menor fila de prontos;

fim

se Encontrou um nó com fila prontos < fila prontos do nó de origem então

| Enviar para execução remota no nó identificado;

senão

| Executar localmente;

fim

\section{Algoritmo 6.1: CPU-total.}

Analisando o algoritmo, observa-se que para cada processo submetido, a máquina receptora compara sua carga com as cargas das demais máquinas do cluster; caso alguma delas possua carga inferior, será identificada como a máquina alvo e o processo recém chegado, será enviado para execução nesta máquina.

A segunda política analisada, denominada "CPU carga média", utiliza o balanceamento de carga por limites, realizando o balanceamento baseando-se na carga média do sistema, seguindo algoritmo 6.2.

Calcular o tamanho médio das filas de prontos dos nós;

se Tam. da fila prontos do nó origem > Tam. médio encontrado então

para cada Nó do cluster faça

| Procurar o nó com a menor fila de prontos;

fim

Enviar para execução remota no nó identificado;

senão

| Executar localmente;

fim

Algoritmo 6.2: CPU carga média.

Essa política somente enviará um processo para execução remota caso a sua carga seja superior à carga média de todas as máquinas do sistema. Caso a política decida enviar um processo para ser executado remotamente, a máquina de destino será aquela com a menor carga, cuja carga será menor que a carga média nos nós do cluster.

As duas abordagens apresentadas até o momento são as mais referenciadas na literatura, mas, em [6] é proposta uma abordagem, denominada neste trabalho como "CPU carga total", que realiza a execução remota apenas quando a fila de prontos encontra-se no tamanho máximo permitido, seguindo o algoritmo 6.3: 
se Fila prontos < Tam. máximo permitido então

| Executar localmente;

senão

Localizar a máquina com menor fila de prontos;

se Tam. fila de prontos nó destino < Tam. fila de prontos nó origem então

| Enviar para execução remota no nó de destino;

senão

| Executar localmente;

fim

fim

Algoritmo 6.3: CPU carga total.

Analisando esse algoritmo, observa-se que ocorre um erro caso o tamanho máximo da fila de prontos utilizado seja o mesmo empregado pelo Linux, uma vez que o processo será "morto" pelo sistema operacional se o tamanho máximo da fila de prontos tiver sido atingido, impedindo que o processo seja enviado para execução remota. Dessa forma, os autores, em [6], propõem um limite imaginário a ser utilizado para a fila de prontos, porém, não descrevem a metodologia de cálculo que indica como esse valor é obtido. A partir desse problema, identificou-se através de inspeção do código fonte do simulador utilizado em [6], que o valor para este limite era de cinco processos.

Dessa forma, realizaram-se simulações com essa configuração, no entanto a política não se apresentou satisfatória para a execução de aplicações memory-intensive, permitindo que o sistema entrasse em estado de trashing a partir da carga "B".

Tentativas com outros valores para o tamanho máximo da fila foram verificados, como 10,20,30,50, 100 e 1000. Porém, todos apresentaram comportamento semelhante ao apresentado com o primeiro limite, de cinco processos. No entanto, como apresentado em [6] e validado pelo simulador deste trabalho, essa política é boa para aplicações $C P U$ bound, cuja configuração de $K$ e $P$ variam entre $1024 \mathrm{~KB}$ e $32768 \mathrm{~KB}$, utilizando $\alpha=5$, determinando a presença maciça de aplicações com baixa utilização de memória.

Esses valores de $k, p$ e $\alpha$, foram obtidos através de uma aproximação por comparação dos traces utilizados em [34], [6] e [33], com os valores gerados pela função de geração da distribuição de Pareto, adotada neste trabalho.

Baseado nessas argumentações, a política descrita, denominada "CPU carga máxima" não será incluída nos resultados analisados a seguir, pois, a perda de desempenho foi muito elevada nas configurações em que o sistema não entrou em estado de trashing, prejudicando a comparação das duas políticas descritas anteriormente.

O estado de trashing é alcançado rapidamente na política "CPU carga máxima" por que ela permite um acúmulo muito grande de processos em apenas um processador e como 
a quantidade de memória consumida por cada processo aumenta à medida em que se varia a configuração de carga passando de "A" para "E", muitas ausências de páginas ocorrem quase simultaneamente. Dessa forma, quando um nó começa a apresentar ausências de páginas, esta já é uma situação assumida pela maioria dos nós do sistema. Assim, é inviável enviar processos para execuções remotas, pois, o sistema já estará totalmente sobrecarregado, entrando em estado de trashing.

Essa situação seria facilmente resolvida se a frequência de processos submetidos fosse baixa, o que caracterizaria um excesso de recursos computacionais no sistema. Porém, analisar sistemas em que a quantidade de recursos supera a demanda, não faz parte dos objetivos deste trabalho.

Apesar desse comportamento apresentado pela política "CPU carga total", as outras duas políticas propostas apresentaram bons resultados em todas as plataformas executadas. Na figura 6.6 é possível verificar a perda de desempenho de ambas as políticas na "Plataforma 1".

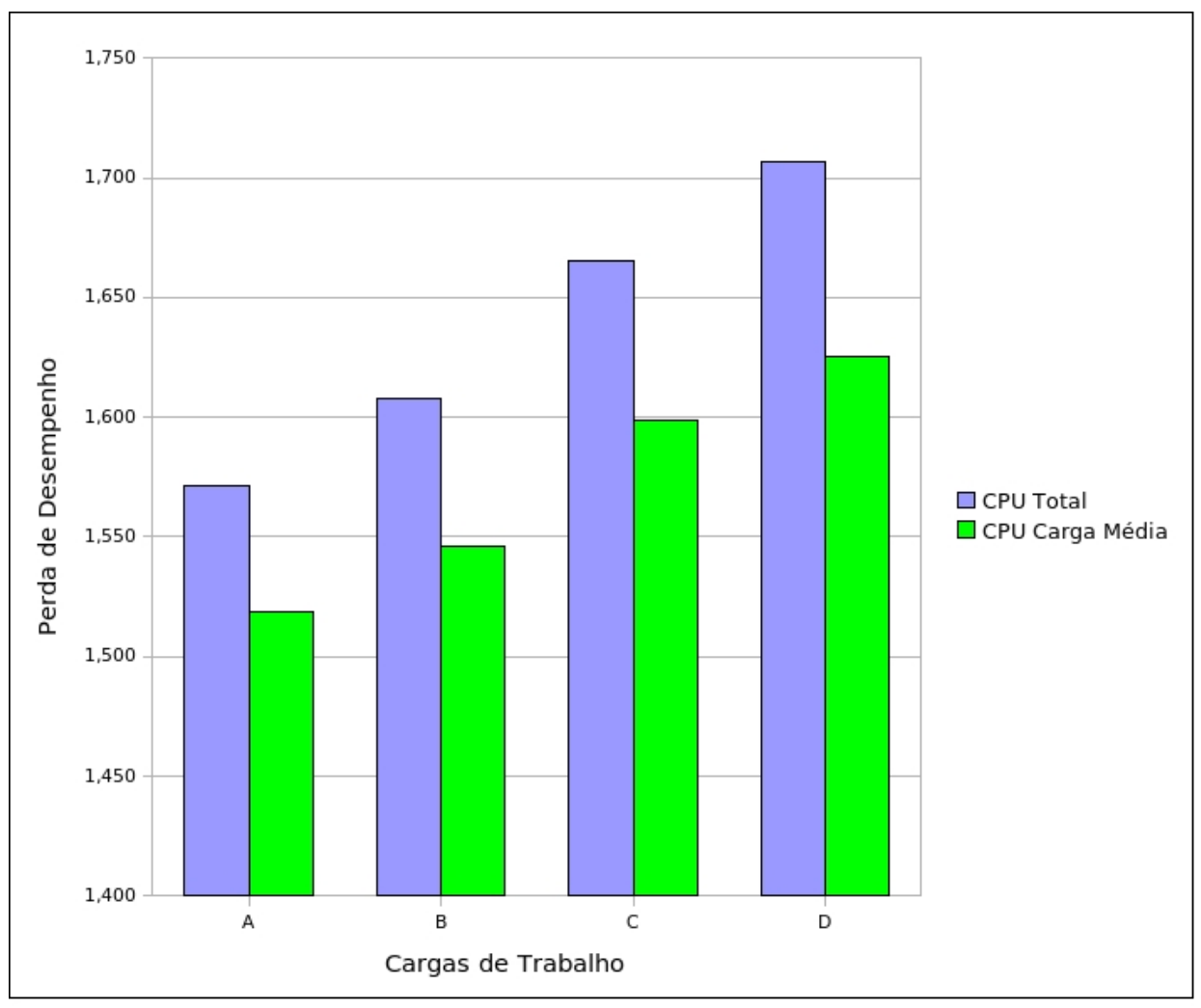

Figura 6.6: Perdas de Desempenho sofridas pelos processos na "Plataforma 1", utilizando políticas baseadas em CPU.

Os valores médios e os intervalos de confiança para os resultados contidos nos gráficos, podem ser observados na tabela 6.5

O nível de confiança utilizado neste trabalho é de $95 \%$, em todos os resultados demonstrados, sendo obtido através da equação 6.2, onde $\alpha$ é o complemento do nível confiança 


\begin{tabular}{|c|c|c|c|c|c|}
\hline \multicolumn{2}{|c|}{} & \multicolumn{4}{|c|}{ Cargas de Trabalho } \\
\hline Política & Resultados & A & B & C & D \\
\hline \multirow{2}{*}{ CPU } & Média & 1,571 & 1,608 & 1,665 & 1,707 \\
\cline { 2 - 6 } & Int. Conf. Sup. & 1,571 & 1,618 & 1,685 & 1,735 \\
\cline { 2 - 6 } & Int. Conf. Inf. & 1,571 & 1,597 & 1,645 & 1,679 \\
\hline \multirow{2}{*}{ CPU } & Média & 1,519 & 1,546 & 1,599 & 1,625 \\
\cline { 2 - 6 } Carga Média & Int. Conf. Sup. & 1,519 & 1,555 & 1,613 & 1,644 \\
\cline { 2 - 6 } & Int. Conf. Inf. & 1,519 & 1,538 & 1,585 & 1,607 \\
\hline
\end{tabular}

Tabela 6.5: Médias e intervalos de confiança da perda de desempenho na "Plataforma 1", utilizando as políticas baseadas em CPU.

desejado. No caso de um nível de confiança de $95 \%, \alpha=0,5$ e $Z_{\alpha / 2}$ é o valor obtido através da tabela T-Students. $\sigma$ é o desvio padrão obtido nas amostras e $N$ é a quantidade de simulações executadas.

$$
\bar{X} \pm\left(Z_{\alpha / 2} * \frac{\sigma}{\sqrt{N}}\right)
$$

Neste trabalho adotaram-se vinte simulações, mas, quando a média de alguma política encontra-se inscrita no intervalo de confiança de outra, realizaram-se mais 10 simulações, tentando evitar essa situação. Isso se faz necessário, pois, com a sobreposição da média dos resultados de uma política "A", com o intervalo de confiança de outra política "B", não é possível definir qual política apresenta o melhor resultado.

Retornando aos resultados da figura 6.6, tem-se que as perdas de desempenho apresentadas pelas duas políticas são muito próximas, todavia, em todas as configurações de carga, para a "Plataforma 1", a política "CPU carga média" apresenta uma perda de desempenho menor quando comparada com a política "CPU total". A vantagem apresentada permanece em torno de $5 \%$, sendo que nenhuma das duas políticas é capaz de manter o cluster executando sem entrar em estado de trashing para a carga "E".

Esse comportamento já era esperado pois, ao balancear a quantidade de processos em execução no sistema, não é realizado o balanceamento de memória. Assim, é possível que alguns nós acumulem processos com uma grande quantidade de memória requerida, enquanto outros estão com processos que utilizam pouca quantidade de memória.

Outro comportamento interessante ocorre quando um dos nós começa a apresentar ausências de páginas em excesso, enviando muitas páginas de processos para disco, mantendo-os no estado bloqueado, o que retira os processos da fila de prontos. Assim, os outros nós identificam o nó congestionado como livre, enviando mais processos para ele, o que o prejudica ainda mais, fazendo-o entrar em estado de trashing.

As diferenças entre as perdas de desempenho apresentadas pelas duas políticas são justificadas pela quantidade de ausências de páginas e pela quantidade de execuções remotas. Na figura 6.7 é possível avaliar a quantidade de ausências de páginas ocorridas na 
plataforma, sob a gerência de ambas as políticas.

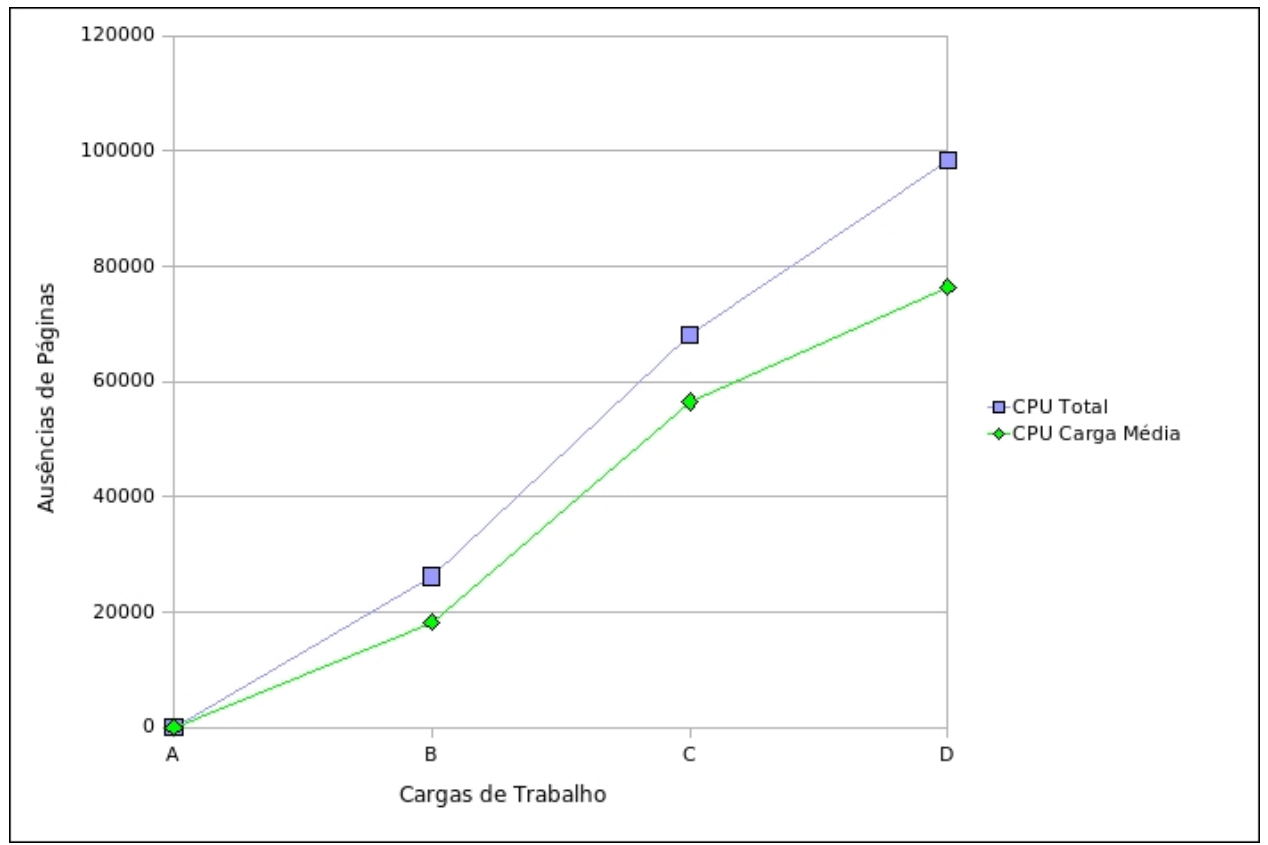

Figura 6.7: Ausências de páginas sofridas pelos processos na "Plataforma 1", utilizando as políticas baseadas em $C P U$.

Analisando-se o gráfico da figura 6.7, percebe-se que a quantidade de ausências de páginas sofridas pelos processos sob a gerência da política "CPU-Total" é maior. Um dos fatores determinantes para esse cenário, é o fato desta política realizar muitas execuções remotas, como pode ser observado no gráfico da figura 6.8.

Essa diferença chega a ser de 8\%, caracterizando uma situação indesejada, pois quando uma máquina "A" está com a menor fila de prontos do sistema, as demais começam a lhe enviar processos, sendo que o tempo entre o envio e o recebimento pelo nó "A" é de pelo menos 100 ms. Neste intervalo de tempo, os demais nós não possuem conhecimento de que o computador "A" já está recebendo processos e continuam lhe enviando mais processos para execução remota, até que os processos sejam recebidos pelo nó "A" e a sua política de informação notifique o novo tamanho da fila.

Essa situação gera o envio de processos em rajadas, destinando grandes quantidades de processos para apenas uma máquina, em um curto espaço de tempo, levando-a a sofrer ausências de páginas.

Ao executar ambas as políticas nas plataformas heterogêneas, o comportamento da perda de desempenho se repete, sendo que a política "CPU carga média" chega a apresentar uma perda de desempenho aproximadamente $17 \%$ menor na "Plataforma 2", com a carga "D".

Após a análise realizada, conclui-se que a política "CPU carga média" é a melhor al- 


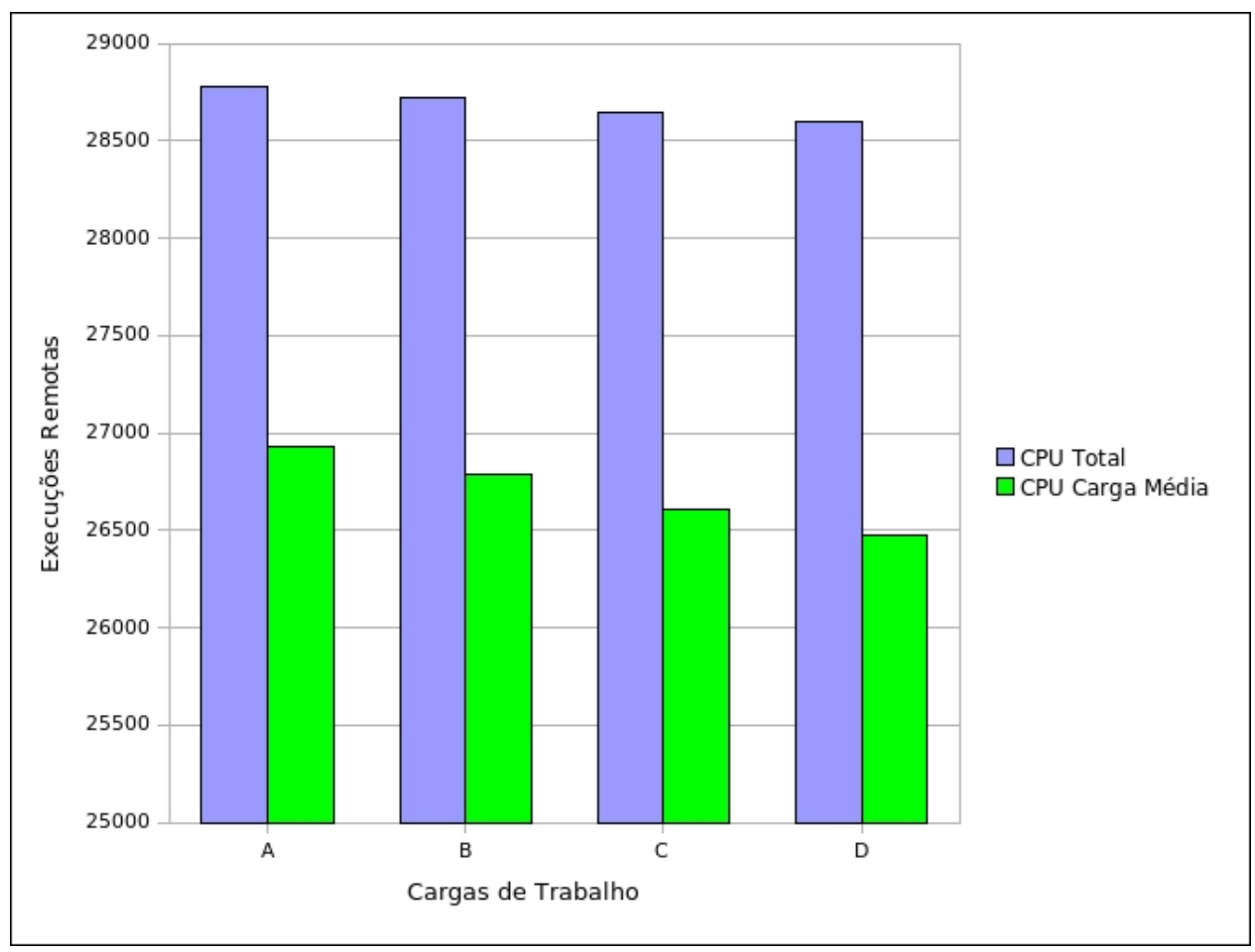

Figura 6.8: Execuções remotas executadas pelos nós da "Plataforma 1", utilizando as políticas baseadas em $C P U$.

ternativa dentre aquelas que utilizam unicamente índices de CPU, para balancear clusters com aplicações memory-intensive. Assim, somente essa política será analisada juntamente com as demais que serão definidas no decorrer deste capítulo, permitindo um estudo gradual das melhores alternativas para esse tipo de sistema.

\subsubsection{Políticas baseadas em memória}

Nesta seção será realizado um estudo das políticas baseadas unicamente em índices de memória, seguindo a mesma linha de raciocínio da seção anterior, onde foram tratas as políticas baseadas em $C P U$.

As políticas utilizam como índice de memória a quantidade de páginas inativas, uma vez que este reflete diretamente a quantidade de memória livre em máquinas que utilizam Linux, conforme discutido no capítulo 4. A métrica 2 (memória realmente ocupada ) e o índice 4 (páginas ativas) poderiam substituir o índice utilizado, apresentando resultados semelhantes.

A primeira política estudada, denominada "Pág. inativa total", segue o mesmo algoritmo da política "CPU total", apenas substituindo o índice tamanho da fila de prontos da CPU, pela quantidade de páginas inativas. Essa política tenta manter a quantidade de páginas inativas totalmente balanceada no cluster. Assim, ao receber um processo, o 
nó de origem verifica se alguma máquina possui mais páginas inativas que ele, enviando o processo para a máquina com a maior quantidade de páginas inativas; caso essa máquina não seja localizada, a política aceitará o processo para execução local.

A segunda abordagem, denominada "Pág. inativa carga média", segue o mesmo algoritmo da política "CPU carga média". Ao receber um processo, a máquina de origem calcula a quantidade média de páginas inativas do sistema, incluindo a sua carga. Caso a sua quantidade de páginas inativas seja menor que a média, ela localizará uma outra máquina, denominada destino, para enviar o processo para execução remota. A máquina de destino deverá ter mais páginas inativas que a média do sistema. Caso um nó com essas características não seja encontrado, o processo será executado localmente.

A terceira política, também proposta em [6], denominada "Pág. inativa carga total" segue a mesma abordagem apresentada no algoritmo 6.3. Nessa abordagem, ao receber um processo, a máquina de origem verifica se a quantidade de páginas inativas é muito próxima de zero, uma vez que o daemon, que gerencia as páginas inativas no Linux, não permite que a quantidade de páginas inativas chegue a zero.

Caso afirmativo, o processo será executado remotamente na máquina com a maior quantidade de páginas inativas; se essa máquina não for localizada, o processo será executado localmente.

Todavia, essa política, assim como a "CPU carga total" não apresentou bons resultados nas simulações executadas, permitindo que o sistema entrasse em estado de trashing com a carga de trabalho denotada por "C".

Isso ocorre por que à medida em que se aumenta a quantidade de processos memoryitensive, maior é a quantidade total de memória solicitada pelos processos. Assim, ao deixar a quantidade de memória disponível se esgotar em um nó, uma grande quantidade de ausências de páginas será gerada, iniciando um processo de execução remota para a máquina com a maior quantidade de memória disponível, desbalanceando a quantidade de processos no sistema, levando essa máquina, também, a apresentar uma grande quantidade de ausências de páginas, já que não é preciso muitos processos para ocupar toda a memória disponível em um nó.

Ambas as políticas propostas em [6] não conseguem tratar aplicações memoryintensive pelo mesmo motivo, realizando poucas execuções remotas, permitindo uma sobrecarga prematura em alguns nós, levando-os a enviar uma quantidade muito grande de processos para o nó menos congestionado, congestionando-o posteriormente. Esse processo segue em cascata até o momento em que o último nó com maior quantidade de recurso disponível, também fique sobrecarregado.

Para que essa situação não ocorra, o cluster tem que trabalhar com taxas de chegadas 
entre processos muito pequena, permitindo que o sistema se recupere do desbalanceamento de carga gerado. Porém, ao verificar os traces disponíveis no repositório parallel Workload Archives, conclui-se que esta não é uma característica das plataformas distribuídas.

Assim como na seção anterior, os resultados apresentados nesta seção também não incluem a política "Pág. inativa carga total", devido aos motivos já relatados.

A figura 6.9 apresenta as perdas de desempenho sofridas pelos processos utilizando as políticas "Pág. inativa total" e "Pág. inativa carga média" na "Plataforma 1", e a tabela 6.6 apresenta as médias obtidas e os intervalos de confiança para a perda de desempenho nesta plataforma.

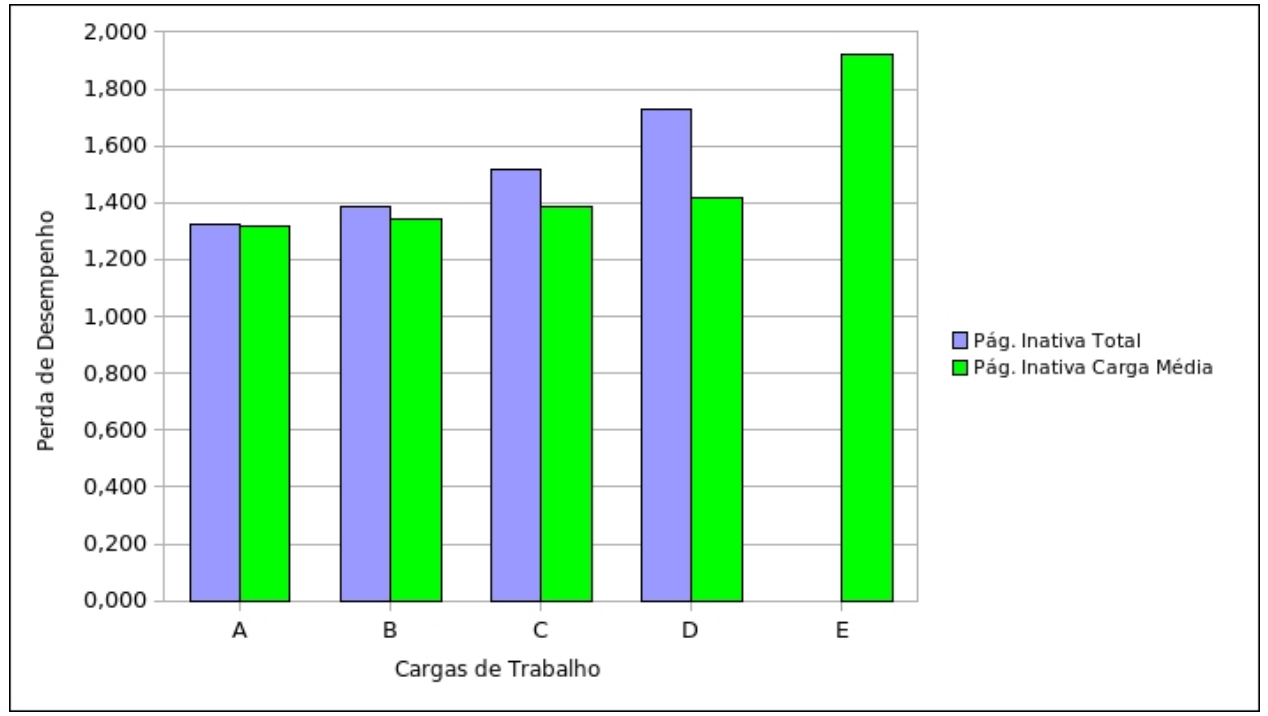

Figura 6.9: Perdas de desempenho sofridas pelos processos na "Plataforma 1", utilizando as políticas baseadas em memória.

\begin{tabular}{|c|c|c|c|c|c|c|}
\hline \multicolumn{2}{|c|}{} & \multicolumn{5}{|c|}{ Cargas de Trabalho } \\
\hline Política & Resultados & A & B & C & D & E \\
\hline $\begin{array}{c}\text { Pág. Inativa } \\
\text { Total }\end{array}$ & Média & 1,327 & 1,386 & 1,518 & 1,728 & Trashing \\
\cline { 2 - 7 } & Int. Conf. Sup. & 1,329 & 1,403 & 1,552 & 1,792 & Trashing \\
\cline { 2 - 7 } & Int. Conf. Inf. & 1,324 & 1,368 & 1,484 & 1,665 & Trashing \\
\hline $\begin{array}{c}\text { Pág. Inativas } \\
\text { Carga Média }\end{array}$ & Média & 1,321 & 1,342 & 1,388 & 1,418 & 1,920 \\
\cline { 2 - 7 } & Int. Conf. Sup. & 1,324 & 1,351 & 1,402 & 1,436 & 2,051 \\
\cline { 2 - 7 } & Int. Conf. Inf. & 1,318 & 1,333 & 1,373 & 1,399 & 1,790 \\
\hline
\end{tabular}

Tabela 6.6: Médias e intervalos de confiança da perda de desempenho na "Plataforma 1", utilizando as políticas baseadas em memória.

Analisando-se o gráfico da figura 6.9, observa-se que à medida em que o tipo de carga passa de "A" para "E", a relação entre a perda de desempenho de ambas as políticas aumenta, apresentando valores que variam entre $0,5 \%$ e $18 \%$ aproximadamente, para as cargas "A" e "D", respectivamente. Ao executar a simulação para a carga "E" a política 
"Pág. inativa total" não foi capaz de manter o sistema estável, permitindo-o entrar no estado de trashing, devido às ausências de páginas ocorridas.

Como pode ser observado no gráfico da figura 6.10, a quantidade de ausências de páginas aumenta proporcionalmente à perda de desempenho sofrida por ambas as políticas, sendo que a política "Pág. inativa total" chegou a sofrer aproximadamente $69 \%$ mais ausências de páginas que a política "pag. inativa carga média" para a carga do tipo "D".

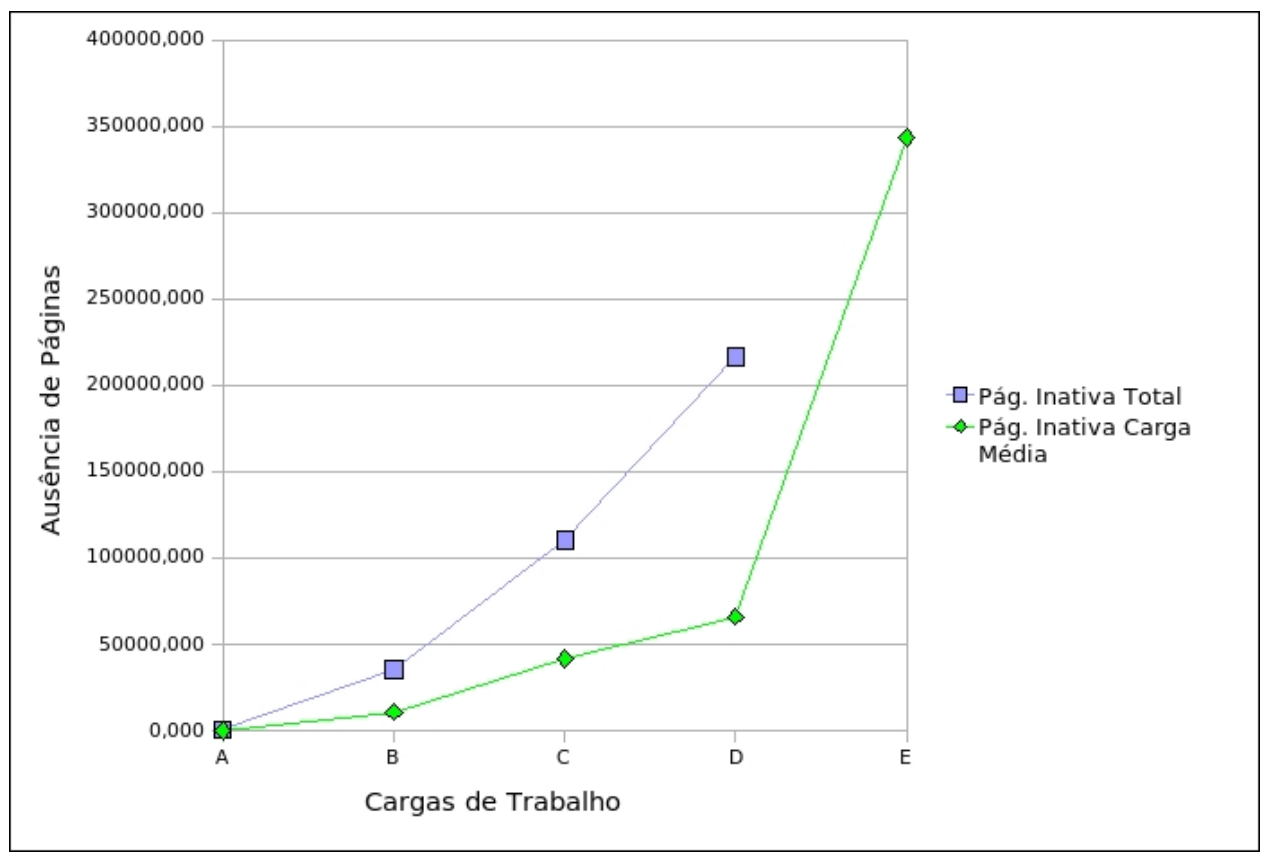

Figura 6.10: Ausência de páginas sofridas pelos processos na "Plataforma 1", utilizando as políticas baseadas em memória.

A política "Pág. inativa total" apresenta o mesmo problema encontrado na política "CPU total". Utilizando essa política, um nó inicialmente descarregado recebe, através de execuções remtas, uma grande quantidade de processos para serem executados pois, no intervalo entre o envio de um processo para execução remota, pela máquina de origem, e o recebimento na máquina de destino, muitos outros processos são enviados para a mesma máquina de destino, até que esses processos comecem a chegar na máquina de destino e esta informe sua carga para as demais.

Esse envio de processos para execução remota, entre os nós do cluster é prejudicial ao sistema, pois, apesar de balancear a memória, o que naturalmente gera menos execuções remotas do que a política "CPU total", a política "Pág. inativa total" permite o acúmulo de um grande número de processos que utilizam pouca memória em conjunto de nós, e um outro conjunto de computadores que recebem poucos processos, que utilizam grandes quantidades de memória.

O gráfico da figura 6.11 apresenta a quantidade de execuções remotas executadas, utilizando-se as duas políticas baseadas em memória. 


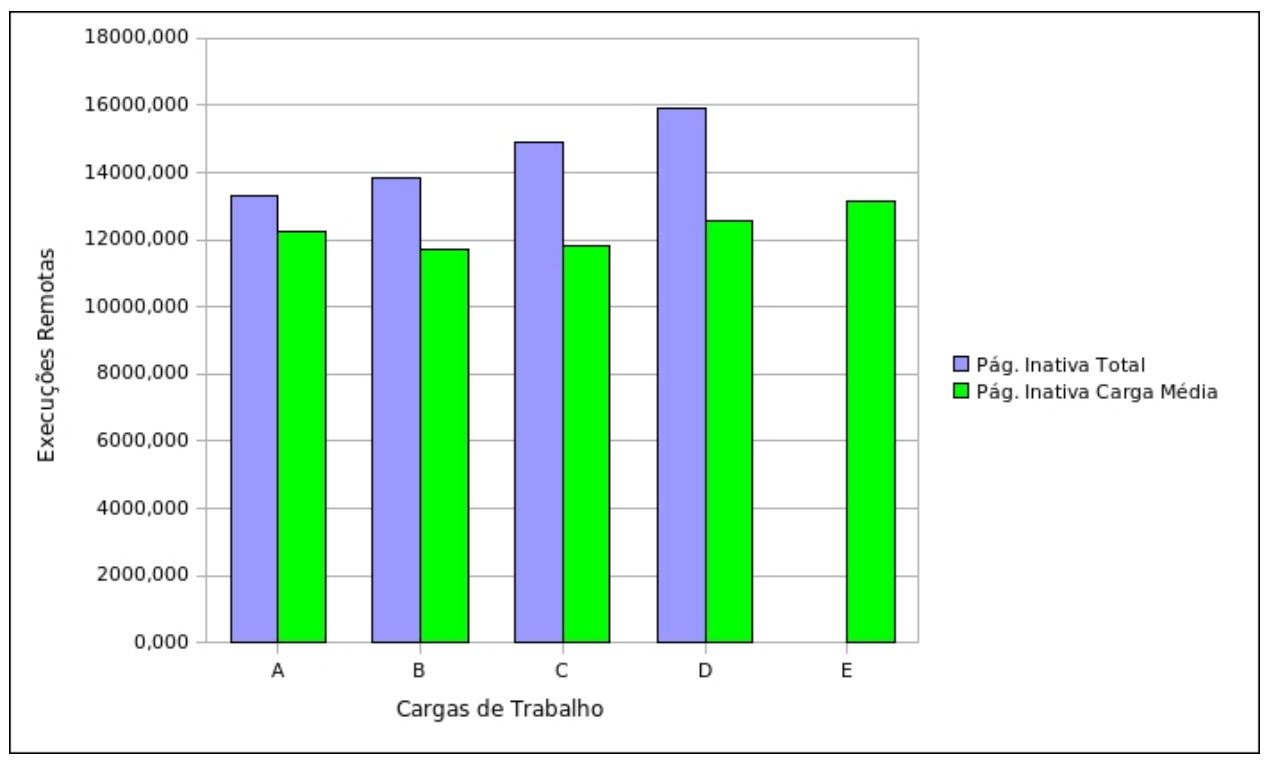

Figura 6.11: Execuções remotas executadas na "Plataforma 1" pelas políticas baseadas em memória.

Apesar de apresentar perdas de desempenho maiores que a política "Pág. inativa carga média", a política "Pág. inativa total" apresenta tempos na fila de prontos menor que a sua concorrente, entre as cargas "A" e "C". Nessas configurações a quantidade mínima de memória que poderá ser solicitada por um processo é pequena, 64 MB. Sendo assim, grande parte dos processos permanecem em tráfego pela rede por um tempo significativo, reduzindo o tamanho médio da fila de prontos da CPU, como pode ser observado no gráfico 6.12 .

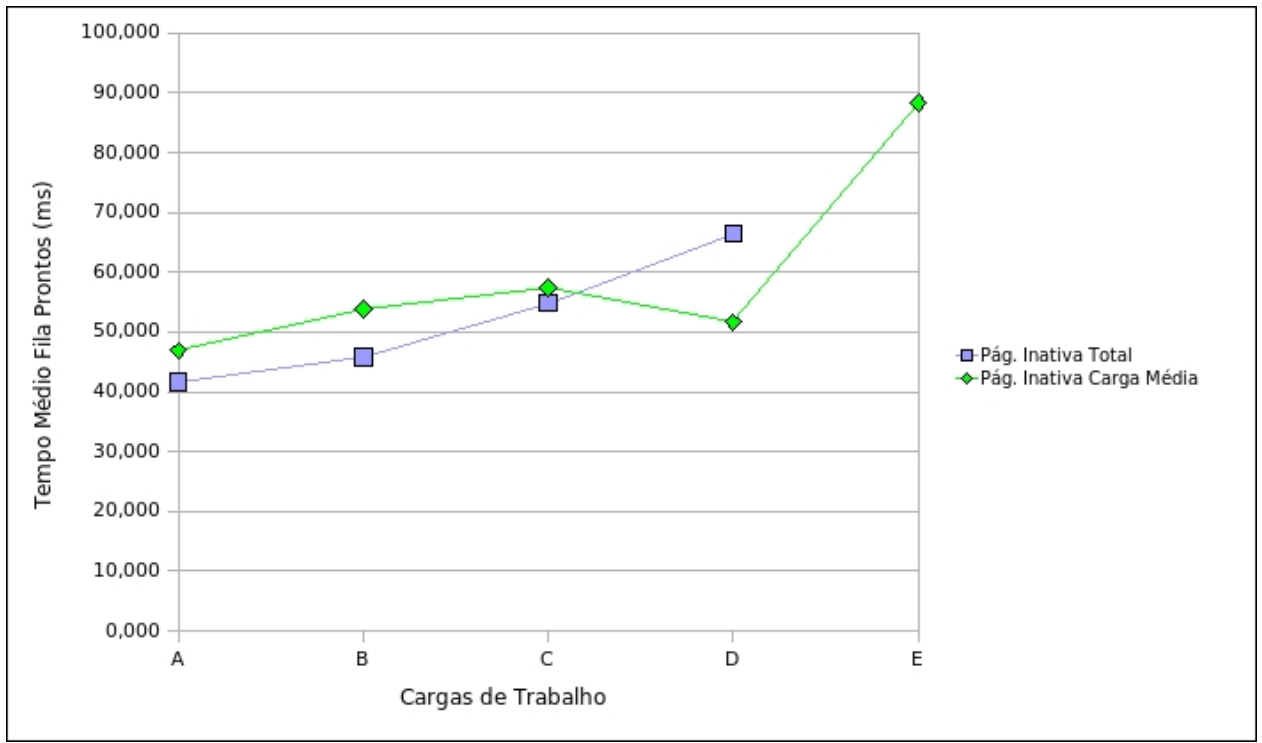

Figura 6.12: Tempo médio gasto na fila de prontos, pelos processos, na "Plataforma 1", utilizando as políticas baseadas em memória.

Através da tabela 6.6, pode-se afirmar que com 95\% de confiança, a política "Pág. 
inativa carga média", apresenta resultados superiores aos obtidos pela política "Pág. inativa total". Como essa mesma situação ocorre nas demais plataformas, optou-se pela política baseada em carga média para ser a política de referência, utilizando-se índices de ocupação de memória DRAM.

\subsection{Políticas propostas}

Foram desenvolvidas quatro novas políticas de escalonamento para ambientes de cluster, com o objetivo de escalonar aplicações memory-intensive.

A primeira política, denominada "CPU carga média com DP", é uma melhoria proposta na política "CPU carga média"3, permitindo que os sistemas existentes sejam modificados com facilidade, adaptando-se uma política direcionada aos sistemas cujas cargas são predominantemente CPU-bound, visando a escalonar as aplicações memory-itensive com maior eficiência. Essa política, ao ser proposta, não possui como objetivo superar as políticas que utilizam índices de memória e sim, melhorar aquelas que utilizam apenas índices de CPU, que são freqüentemente utilizadas [32].

A segunda política proposta, utiliza os conceitos do algoritmo Assign-u [29], para homogeneizar os índices heterogêneos e as duas últimas utilizam o conceito de grupos, desenvolvido neste trabalho, utilizando informação tanto de CPU quanto de memória para realizar o escalonamento.

\subsubsection{Baseada em CPU}

Ao analisar o comportamento da política "CPU carga média" com a política "Pág. inativa carga média", tem-se que esta realiza menos execuções remotas que aquela, como pode ser observado no gráfico da figura 6.13, que registra a quantidade de execuções remotas executas por ambas as políticas nas quatro plataformas estudadas.

As quantidades de execuções remotas registradas no gráfico da figura 6.13 , são o acumulado dos resultados obtidos ao submeter o sistema às cargas de trabalho entre "A" e "D". A carga "E" foi retirada dos resultados totalizados, pois, a política "CPU carga média" permitiu que o sistema entrasse em estado de trashing na maioria das plataformas, o que não ocorre com a política "Pág. inativa carga media".

Ao analisar esse gráfico, observa-se que as diferenças entre as quantidades de execuções remotas chegam à aproximadamente $120 \%$ para a "Plataforma 1" e a $45 \%$ para a "Plataforma 3".

\footnotetext{
${ }^{3}$ Apresentada na seção 6.4 .
} 


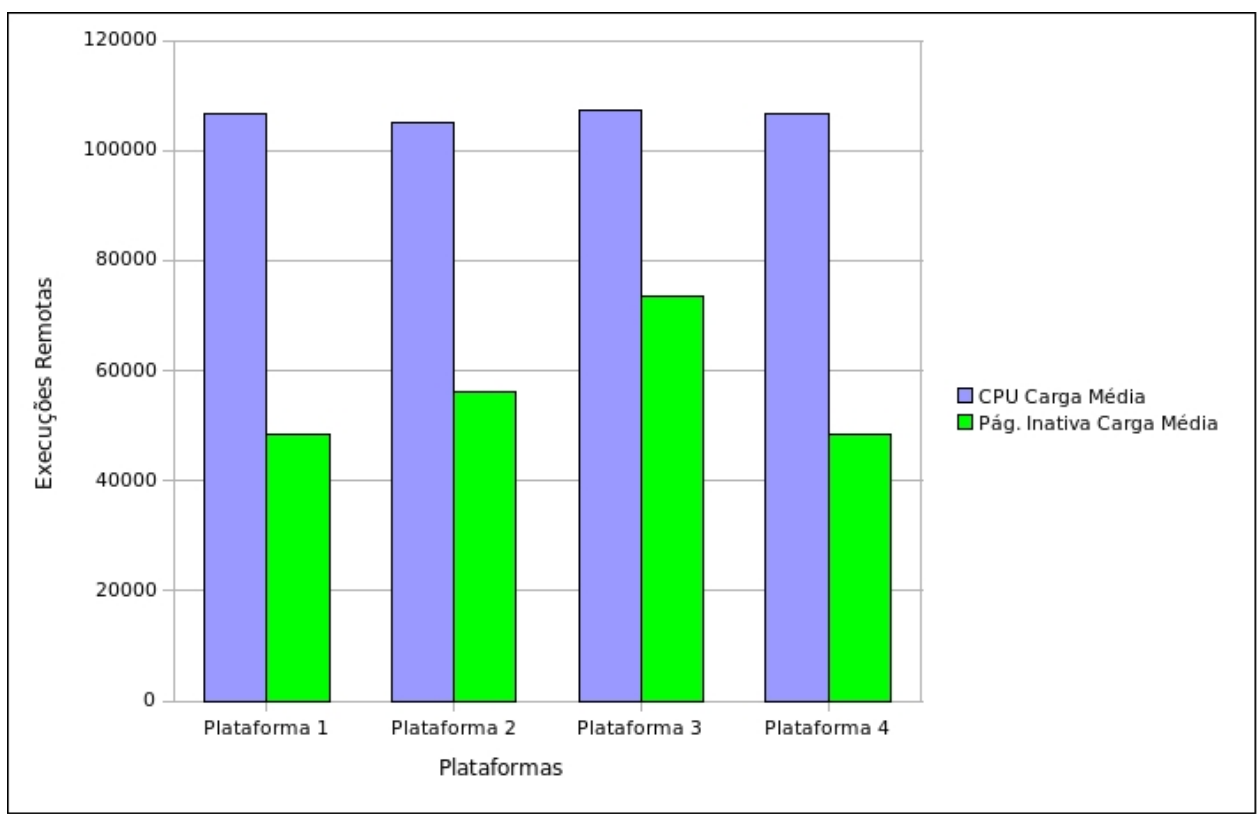

Figura 6.13: Quantidade de execuções remotas realizadas pelas políticas "CPU carga média" e "Pág. inativa carga média" nas plataformas analisadas.

Outro fator que levou a esta conclusão é o fato da política "CPU carga média" ser mais eficiente que a "CPU total" e executar menos execuções remotas, como pode ser observado no gráfico da figura 6.8 .

Após analisar esses resultados, propõe-se a utilização do desvio padrão para diminuir a quantidade de execuções remotas executadas pela política "CPU carga média", dando origem à política "CPU carga média com DP", descrita no algortimo 6.4.

Calcular o tamanho médio das filas de pronto dos nós;

$\mathrm{dp}=$ desvio padrão dos tamanhos das filas de prontos;

se Tam. da fila prontos do nó origem $>$ Tam. médio encontrado $+d p$ então

para cada Nó do cluster faça

| Procurar o nó com a menor fila de prontos;

fim

Enviar para execução remota no nó identificado;

senão

| Executar localmente;

fim

Algoritmo 6.4: CPU carga média com DP.

Observa-se que o desvio padrão é utilizado apenas no momento de decidir se uma execução remota deve, ou não, ser executada. Na literatura encontram-se políticas que utilizam um valor $\delta$ para reduzir a quantidade de execuções remotas das políticas, no entanto, esse valor é um tanto vago, pois não há um concenso de qual o melhor valor a ser empregado. Assim, utilizar o desvio padrão, põe um ponto final em qual valor gerar 
e ainda permite flexibilidade, uma vez que o desvio padrão não é uma constante, como o valor de $\delta$ proposto na literatura.

O gráfico da figura 6.14 apresenta as reduções nas quantidades de execuções remotas realizadas por plataforma e por carga de trabalho.Através deste gráfico é possível observar que a maior redução para as cargas variando de "A" até "C", ocorre na "Plataforma 2", que apresenta heterogeneidade de CPU, onde o desvio padrão entre os tamanhos das filas é maior, pois, as máquinas com maiores capacidades de processamento tendem a receber processos em rajadas, devido às execuções remotas das máquinas de menor potência computacional.

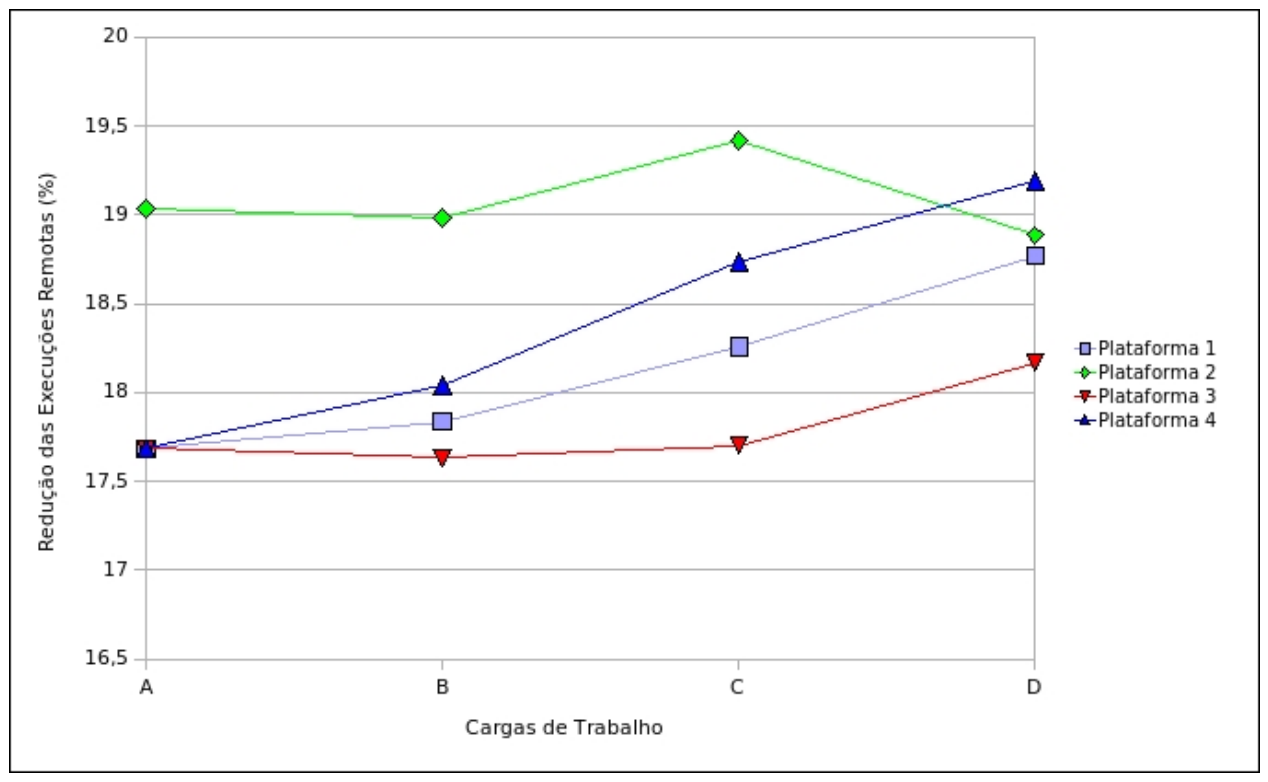

Figura 6.14: Reduções na quantidade de execuções remotas realizadas pelas políticas "CPU carga média" e "CPU carga média com DP".

Para a carga "D" as plataformas 1,2 e 4 apresentam resultados muito próximos, com variação de no máximo $1,36 \%$.

A média de redução na quantidade de execuções remotas, utilizando a política "CPU carga média DP" foi de aproximadamente 18,36\%. Os resultados obtidos por essa política, em comparação à política "CPU carga média", pode ser observada na seção 6.6, bem como seus resultados perante às demais políticas que utilizam informações de memória.

\subsubsection{Baseada no algoritmo Assign-u}

O algoritmo Assign-u permite a conversão, de maneira eficiente, de índices heterogêneos em apenas um índice, $\mu$, homogêneo. Na política proposta nesta seção, será utilizada apenas a equação de homogeneização dos índices, pois o Assign-u é um algoritmo completo de escalonamento. Entretanto, é necessário o conhecimento da quantidade de recursos que 
um determinado processo irá necessitar, o que não reflete os objetivos deste trabalho, que utiliza escalonamento dinâmico, através de informações da plataforma e não dos processos.

A equação de homogeneização, adaptada, para gerar o índice $\mu$ em uma máquina com $r$ recursos é definida em 6.3 .

$$
\mu=\sum_{i=1}^{r} \frac{\text { Carga atual recurso }_{i}}{\text { Capacidade total recurso }}
$$

Muitas combinações de índices foram avaliadas, no entanto, a utilização dos índices tamanho da fila de prontos da CPU e a quantidade de páginas ativas, índice 4, são os mais promissores. Assim, a segunda política proposta neste trabalho, denominada "Assign-u(CPU + Pág. ativa)", é definida de acordo com o algoritmo 6.5, dado que o cluster possui $\mathrm{N}$ nós, onde $0 \leq i<N$, e i denota cada nó do ambiente, sendo identificado por $N o_{i}$.

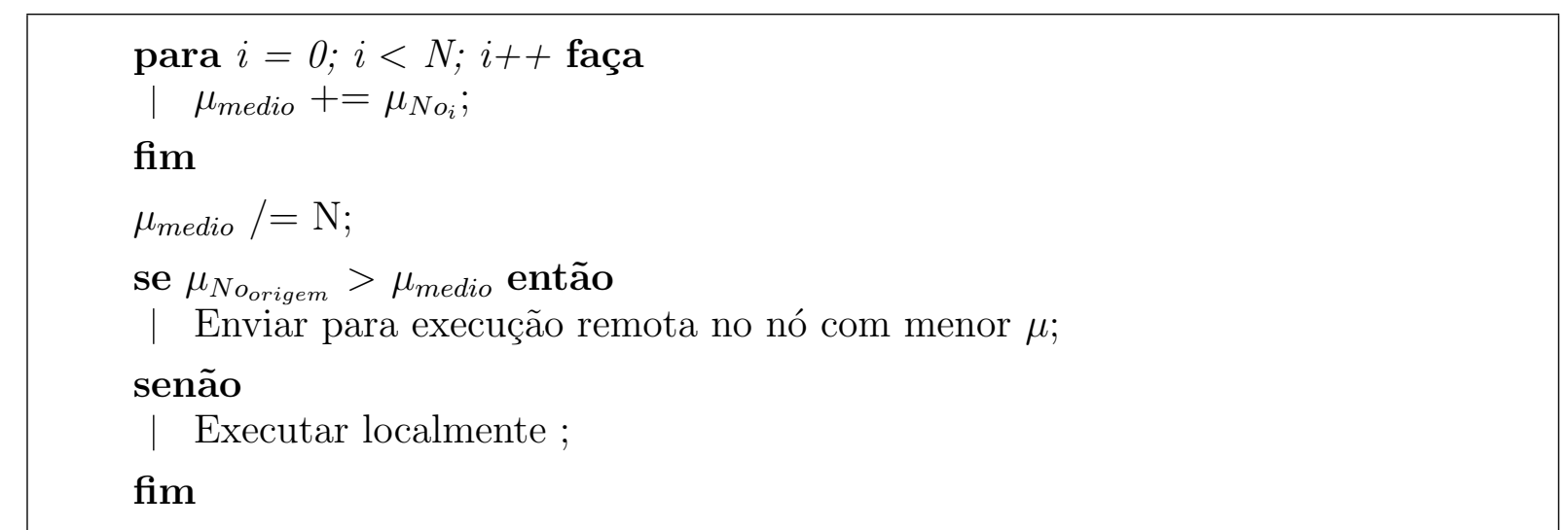

Algoritmo 6.5: Assign-u(CPU + pág. ativa).

Analisando-se esse algoritmo, nota-se que é utilizado o conceito de carga média do sistema, dado pelo cálculo do $\mu_{\text {medio. }}$ Essa abordagem é utilizada pois, observando-se os resultados de todas as simulações com diversas políticas avaliadas, conclui-se que a utilização da carga média é a alternativa mais eficiente dentre as três combinações existentes e descritas no capítulo 3 .

\subsubsection{Baseadas em grupos}

$\mathrm{Na}$ literatura, algumas políticas analisam separadamente índices heterogêneos mas, nessas políticas, a decisão é tomada por apenas um dos índices, dependendo do estado da plataforma no momento do escalonamento.

O conceito de grupo desenvolvido neste trabalho, consiste em realizar $n$ seleções, onde cada uma das $n$ etapas analisará um índice diferente, retirando os nós que não atendem aos 
requisitidos pré-estipulados, sendo a n-ésima seleção a responsável por indicar a máquina alvo, que receberá o processo para execução remota.

A terceira política proposta neste trabalho, denominada "Grupo Pág. Ativa + CPU" utiliza o conceito de grupo descrito, com $n=2$, utilizando-se os índices páginas ativas e tamanho da fila de prontos da CPU para realizar o escalonamento, tomando a decisão em duas etapas.

A primeira etapa consiste em selecionar as máquinas cujas quantidades de páginas ativas sejam menores que a quantidade média de páginas ativas nas máquinas do cluster. A segunda etapa consiste em selecionar, dentre as máquinas previamente selecionadas, na etapa anterior, aquela que apresenta a menor fila de prontos.

O algoritmo 6.6 define a política "Grupo pág. ativa + CPU", dado que $\epsilon$ denota a quantidade de páginas ativas, sendo representado por $\epsilon_{N o_{i}}$ a quantidade de páginas ativas na máquina $i$ do cluster. Nesse algoritmo as variáveis $i$ e $N$ seguem as mesmas definições descritas no algoritmo 6.5.

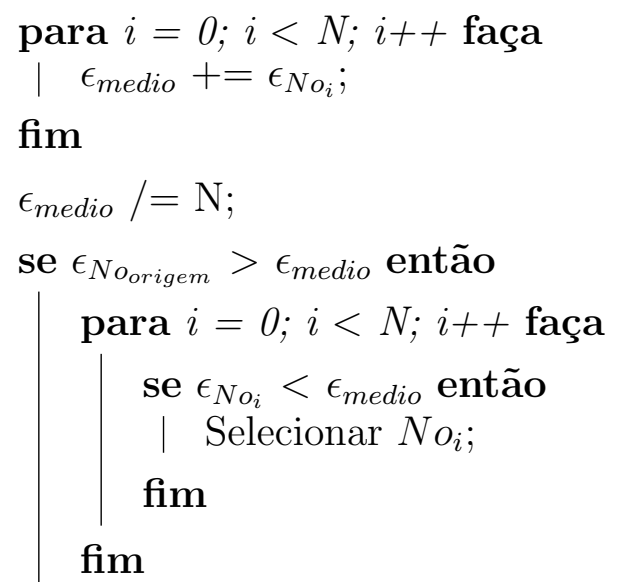

Enviar para execução remota no nó, entre os selecionados, com a menor fila de prontos;

senão

| Executar localmente ;

fim

Algoritmo 6.6: Grupo Pág. Ativa + CPU.

A segunda política baseada em grupos, e a quarta política a ser proposta, denominada "Grupo pág. ativa + CPU II", é uma melhoria realizada na política "Grupo pág. ativa + CPU" proposta anteriormente.

A diferença encontra-se no momento de selecionar a máquina de destino, onde não somente o tamanho da fila de prontos é considerada, mas também a quantidade de processos enviados para execução remota nesse nó. 
Para armazenar essa informação é necessário que as máquinas registrem a quantidade de processos enviados para cada computador, trocando esta informação por mensagens broadcast. As máquinas que recebem processos, por sua vez, devem subtrair esse valor a cada processo recebido, também informando aos demais nós do sistema.

Ambas as políticas baseadas em grupos, propostas nesta seção, utilizam como índices a quantidade de páginas ativas e o tamanho da fila de prontos da CPU, mas outros índices poderiam ser utilizados, bem como utilizar três ou mais índices. Porém, nas simulações desenvolvidas neste trabalho, a utilização de ambos os índices formaram as duas políticas com melhores resultados, o que não descarta a tentativa de novas combinações para trabalhos futuros.

\subsection{Avaliação das políticas propostas}

A avaliação das políticas propostas é realizada em quatro etapas, coincidindo com as plataformas propostas. Assim, na primeira etapa é realizada a avaliação dos resultados obtidos na plataforma homogênea, utilizando-se os resultados obtidos na "Plataforma 1". Na seqüência são analisados os impactos causados pela heterogeneidade de CPU, memória e disco, utilizando as plataformas 2, 3 e 4, respectivamente.

No decorrer desta seção, em alguns casos, os gráficos envolvendo as políticas com índices unicamente de CPU, serão apresentados separadamente daqueles contendo os resultados das políticas que utilizam índices de memória. Isto facilitará a análise das políticas, visto que a política "CPU carga média com DP" é uma melhoria proposta à política "CPU carga média", enquanto as demais são alternativas para as políticas que utilizam índices de memória.

No entanto, em casos em que os resultados apresentados por ambas as categorias de políticas são aproximados, os gráficos serão apresentados em conjunto, permitindo uma comparação mais abrangente.

Apesar da análise separada, as tabelas contendo as médias e os intervalos de confiança, disponibilizarão as informações de todas as políticas analisadas, facilitando o confronto direto entre todas elas.

\subsubsection{Plataforma homogênea}

Os resultados envolvendo as políticas baseadas em CPU encontram-se na figura 6.15.

Ambas as políticas não foram capazes de executar a carga de trabalho "E", devido à grande quantidade de memória solicitada pelas aplicações. Nas demais cargas, tem-se que 


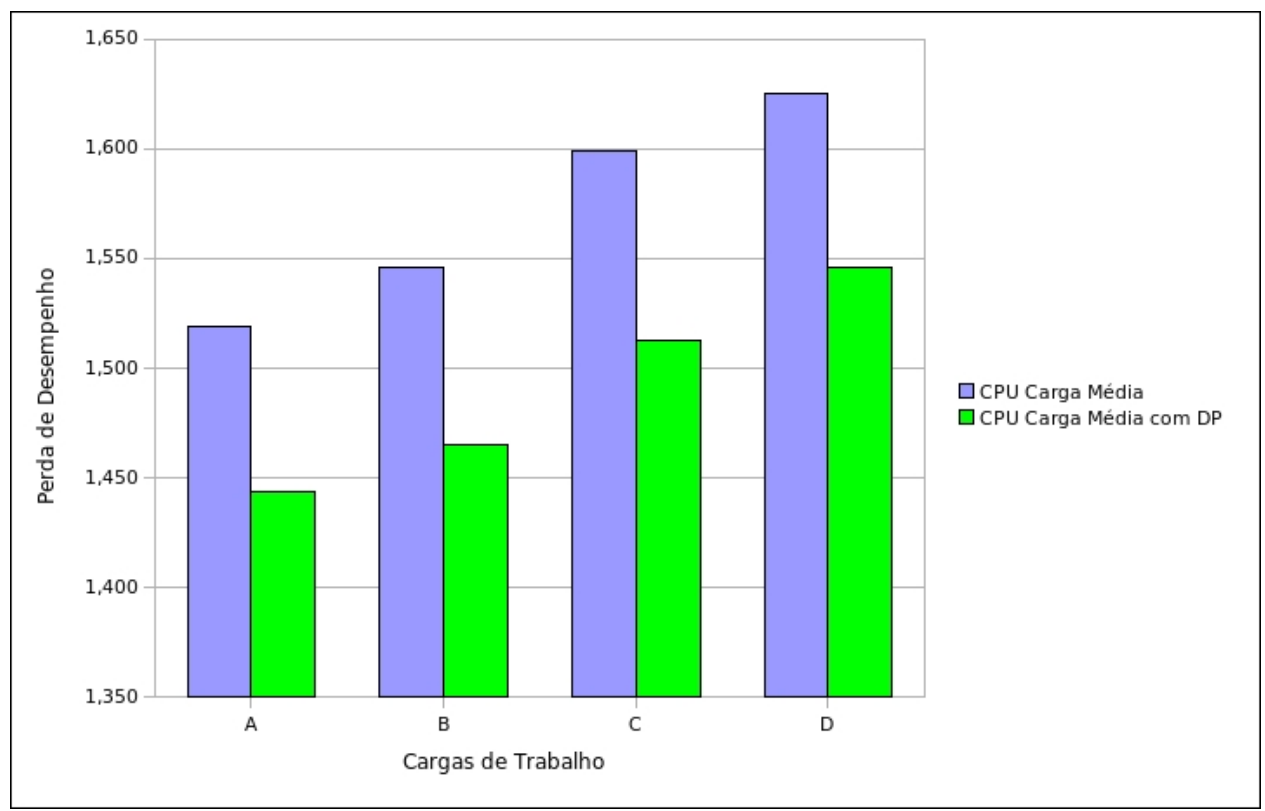

Figura 6.15: Perdas de desempenho sofridas pelas aplicações, na "Plataforma 1", utilizando as políticas baseadas em índices de CPU.

a política "CPU carga média com DP" é superior à política "CPU carga média" entre $4 \%$ e $6 \%$, dependendo da carga analisada.

Analisando-se a tabela 6.7, observa-se que as médias de uma política não se encontram inseridas nos intervalos de confiança da outra, ratificando a afirmação acima.

Conforme mencionado na definição da política "CPU carga média com DP", essa melhora foi obtida através da redução da quantidade de execuções remotas, conforme apresentado na figura 6.14 .

A redução da quantidade de processos enviados para execução remota diminui o tempo que os processos perdem na rede, além de reduzir o envio em rajadas de processos para um nó com menor carga.

A diminuição dos envios em rajadas influencia diretamente a quantidade de ausências de páginas sofridas na plataforma. Esse efeito pode ser visualizado na figura 6.16.

Apesar de melhorar os resultados da política "CPU carga média", a política "CPU carga média com DP" não apresenta resultados superiores aos apresentados pelas políticas que utilizam índices de memória, cujos resultados encontram-se na figura 6.17.

Através desse gráfico é possível observar que, para plataformas homogêneas com carga de trabalho basicamente $C P U$-bound, todas as políticas se mostram eficientes, apresentando uma pequena variação, em torno de $6 \%$, entre a política de referência, "Pág. Inativa Carga Média", e a mais eficiente, "Grupo pag. Ativa + CPU II".

Essa diferença ocorre devido ao balanceamento da fila de prontos realizado pela última 


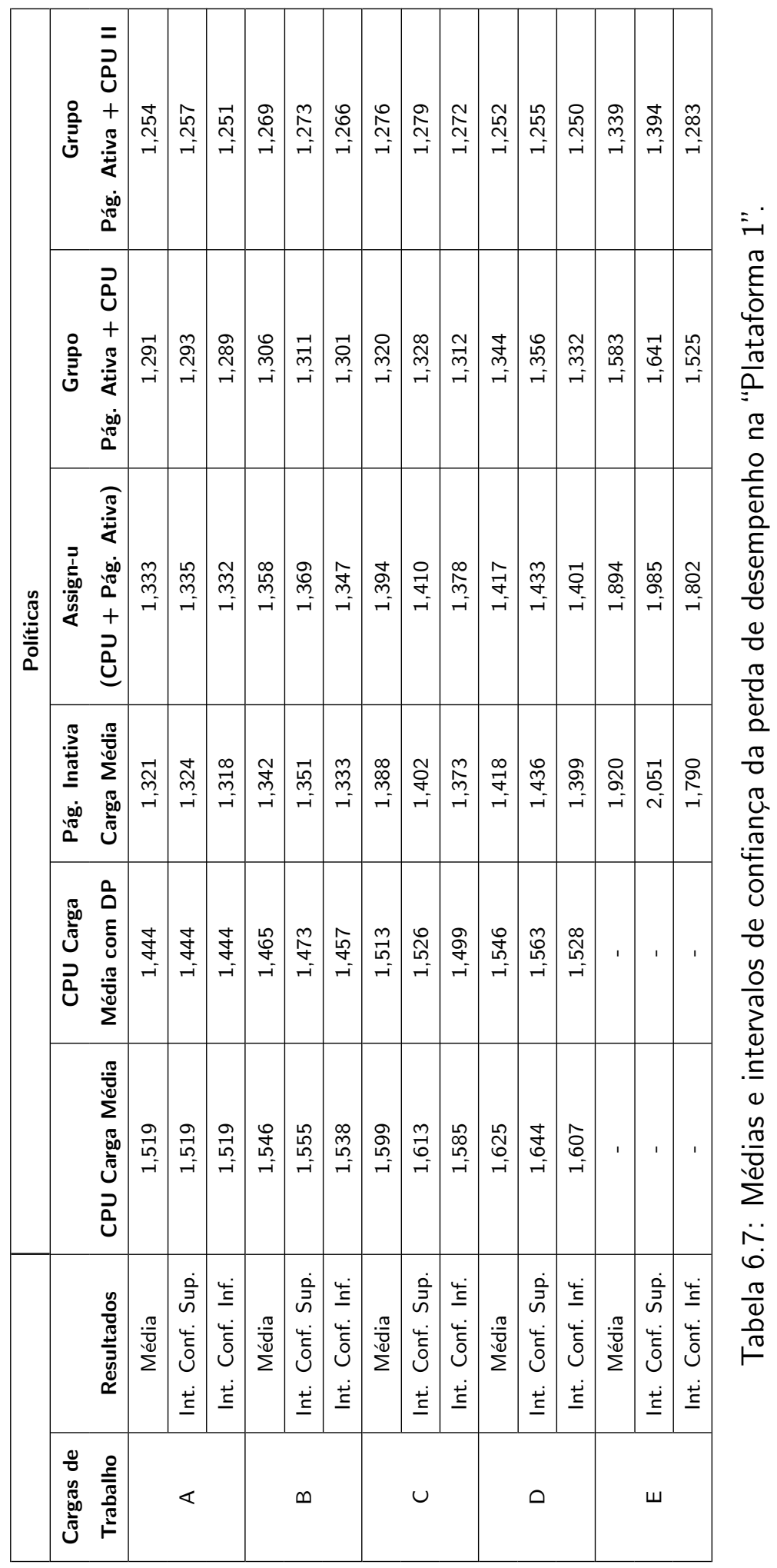




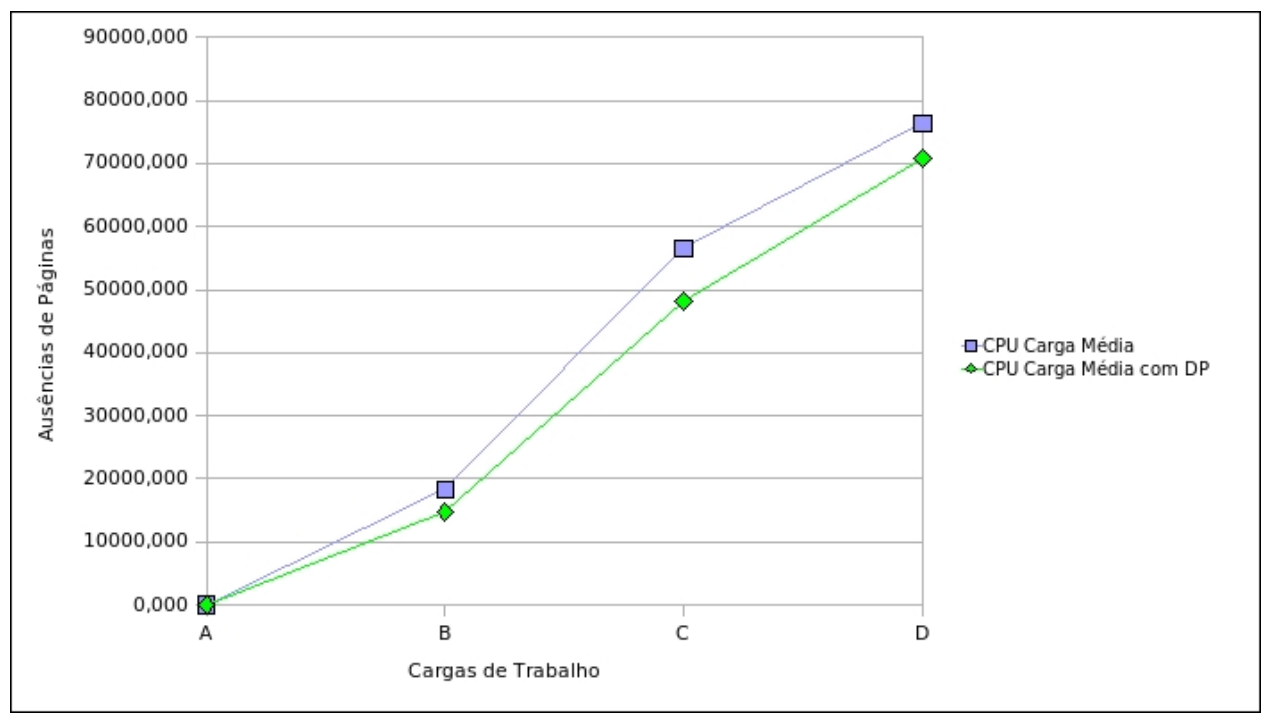

Figura 6.16: Ausências de páginas sofridas pelos processos, na "Plataforma 1", utilizando as políticas baseadas em índices de CPU.

política citada.

Para o mesmo tipo de carga, a política "Assign-u(CPU + Pág. Ativa)" não conseguiu apresentar o mesmo resultado que as políticas baseadas em grupo pois, nessa política, a quantidade de páginas ativas e a quantidade de processos na fila de prontos possuem o mesmo peso.

À medida em que a carga de trabalho deixa de ser dominantemente $C P U$-bound e se direciona para a sobrecarga de aplicações memory-intensive, a política utilizada como referência se torna mais ineficiente. Isto ocorre devido à quantidade de ausências de páginas que esta permite ocorrer, como pode ser observado na figura 6.18.

Para as cargas de trabalho, entre "C" e "E", é possível afirmar que as políticas de referência e a baseada no algoritmo Assign-u são equivalentes, uma vez que as médias de uma encontram-se dentro dos intervalos de confiança da outra, conforme demonstra a tabela 6.7 .

Apesar da pequena vantagem apresentada pela política de referência em relação a "Assign(CPU + Pág. ativa)", para as cargas "A" e "B", e da equivalência nas demais cargas, a política baseada no algoritmo Assign-u conseguiu executar $100 \%$ das simulações com carga "E", contra apenas $70 \%$ apresentado pela política de referência.

Assim, a política "Pág. ativa carga média" permitiu que o sistema entrasse em estado de trashing em $30 \%$ dos casos em que a plataforma foi submetida a uma carga elevada de aplicações memory-itensive.

Analisando-se o gráfico da figura 6.19, observa-se que a equivalência entre a perda de desempenho das políticas "Pág. inativa carga média" e "Assign-u(CPU + Pág. ativa)" é 


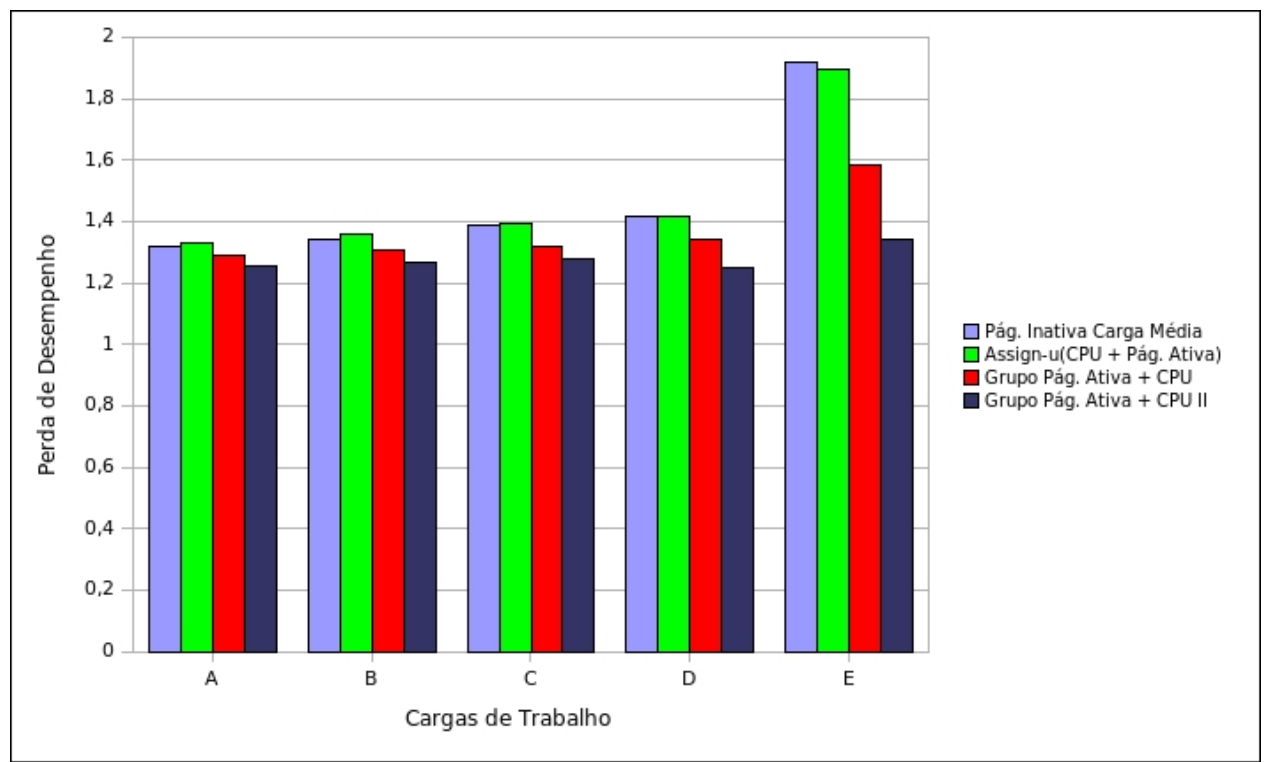

Figura 6.17: Perda de desempenho, na "Plataforma 1", utilizando as políticas baseadas em índices de memória.

conseqüência da quantidade de execuções remotas executadas pela última, que chega a ser aproximadamente $20 \%$ maior na carga "B".

As políticas baseadas em grupo apresentaram redução significativa da perda de desempenho das aplicações, chegando a $17 \%$ e $30 \%$ para a carga de trabalho "E", para as políticas "Grupo pág. inativa + CPU" e "Grupo pág. inativa + CPU II", respectivamente, quando comparadas à política de referência baseada em memória.

Com relação às políticas baseadas em CPU, a segunda política baseada em grupo apresentou $23 \%$ e $19 \%$ menos perda de desempenho, quando comparada às políticas "CPU carga média" e "CPU carga média com DP", respectivamente.

Esse desempenho ímpar, das políticas baseadas em grupo, é conseqüência da pequena quantidade de execuções remotas e da redução do número de ausências de páginas geradas, quando comparado às políticas menos eficientes. A redução da migração evita o efeito rajada, já discutido anteriormente, reduzindo assim as ausências de páginas.

Além de realizar o balanceamento da CPU, ao ignorar as máquinas com quantidade de páginas ativas acima da média, as políticas baseadas em grupo evitam o acúmulo, em poucas máquinas, de processos que requisitam uma grande quantidade de memória. Esse comportamento determina a superioridade das políticas baseadas em grupo.

\subsubsection{Heterogeneidade de CPU}

Os resultados de perdas de desempenho obtidos pelas políticas baseadas unicamente em índices de CPU, podem ser visualizados na figura 6.20. 


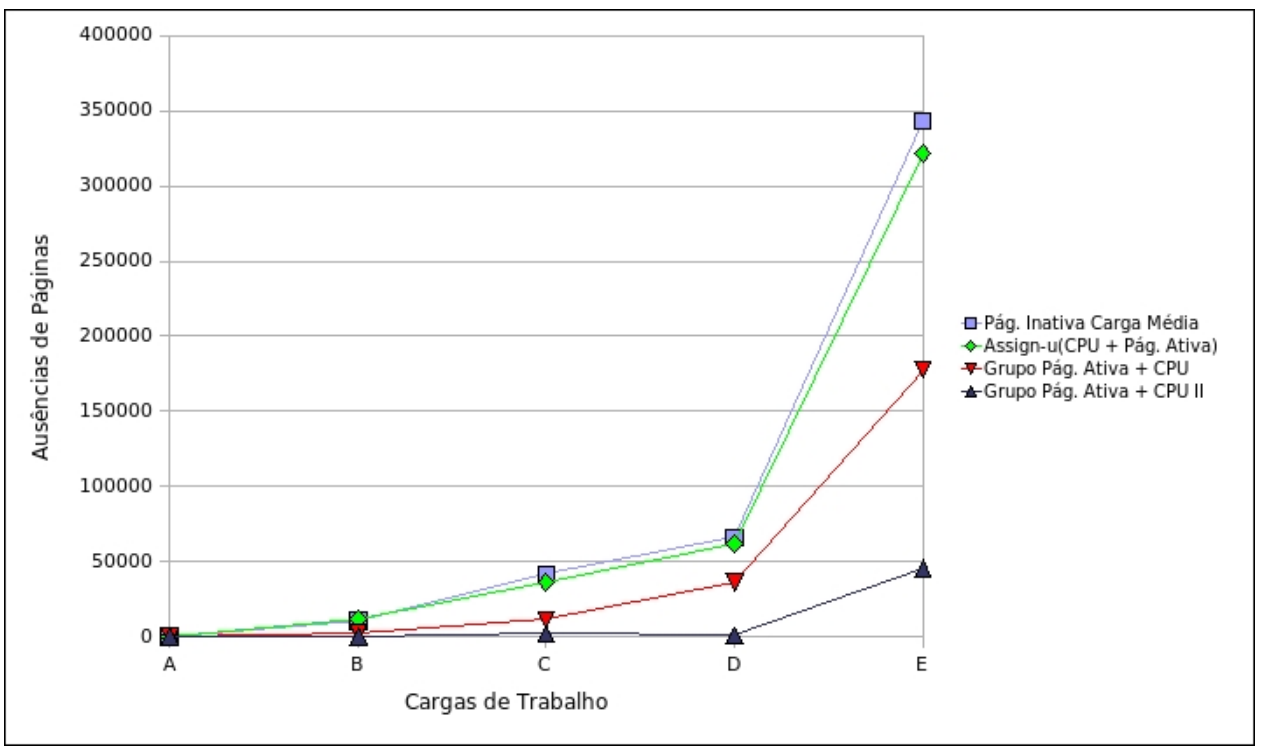

Figura 6.18: Ausências de páginas ocorridas na "Plataforma 1", ao utilizar as políticas baseadas em índices de memória.

Juntamente com os resultados, são apresentados na tabela 6.8 os resultados das médias das perdas de desempenho obtidas durante as simulações para todas as políticas analisadas, com nível de confiança de 95\%, retratados nos campos "Int. Conf. Sup." e "Int. Conf. Inf.".

Nessa plataforma, as políticas baseadas unicamente em índices de CPU não conseguiram impedir a plataforma de entrar no estado de trashing para a carga "E", devido à grande quantidade de ausências de páginas ocasionadas, uma vez que ambas as políticas, por não observarem as quantidades de memória das máquinas, permitem o acúmulo de processos que solicitam uma grande quantidade de memória em um pequeno grupo de máquinas, causando desbalanceamento na quantidade de memória disponível no cluster.

Apesar desse fato, pode-se observar que nas demais cargas de trabalho propostas, a política "CPU carga média com DP" apresentou ganhos de desempenho entre, aproximadamente, $3,04 \%$ e 8,72\%, nas cargas "A" e "D", respectivamente, demonstrando a eficiência do método proposto para plataformas com heterogeneidade na capacidade de processamento.

Essa melhoria no desempenho obtida pela política "CPU carga média com DP" é conseqüência da quantidade de execuções remotas executadas, evitando-se a perda de tempo sofrida pelos processos durante a passagem pela rede e ocasionando um melhor balanceamento da memória, uma vez que os processos submetidos possuem necessidades diferentes de quantidades de memória.

Ao aceitar uma maior quantidade de processos para execução local, permite-se que as requisições de memória sejam distribuídas de uma maneira menos irregular, se comparada 


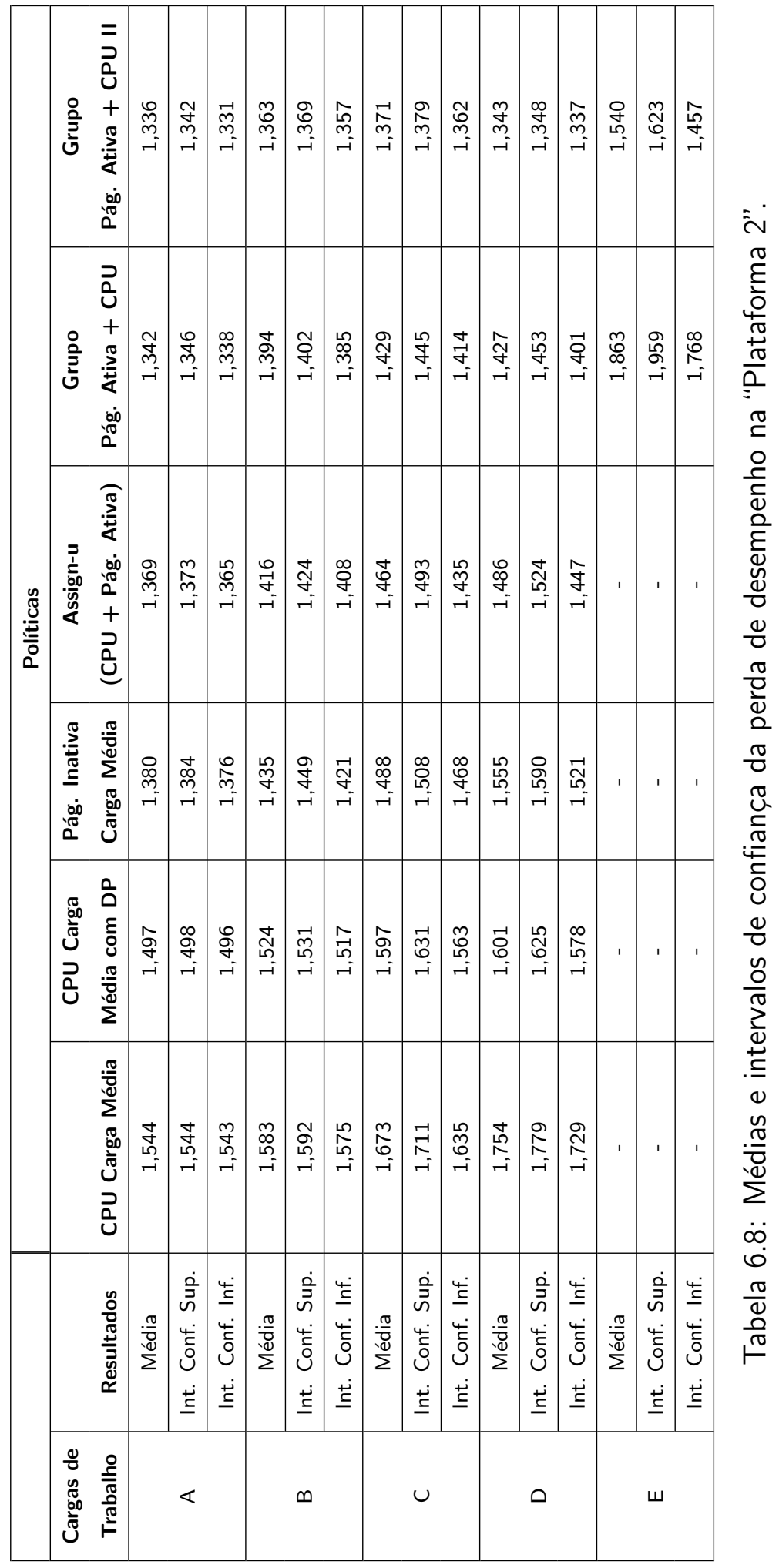




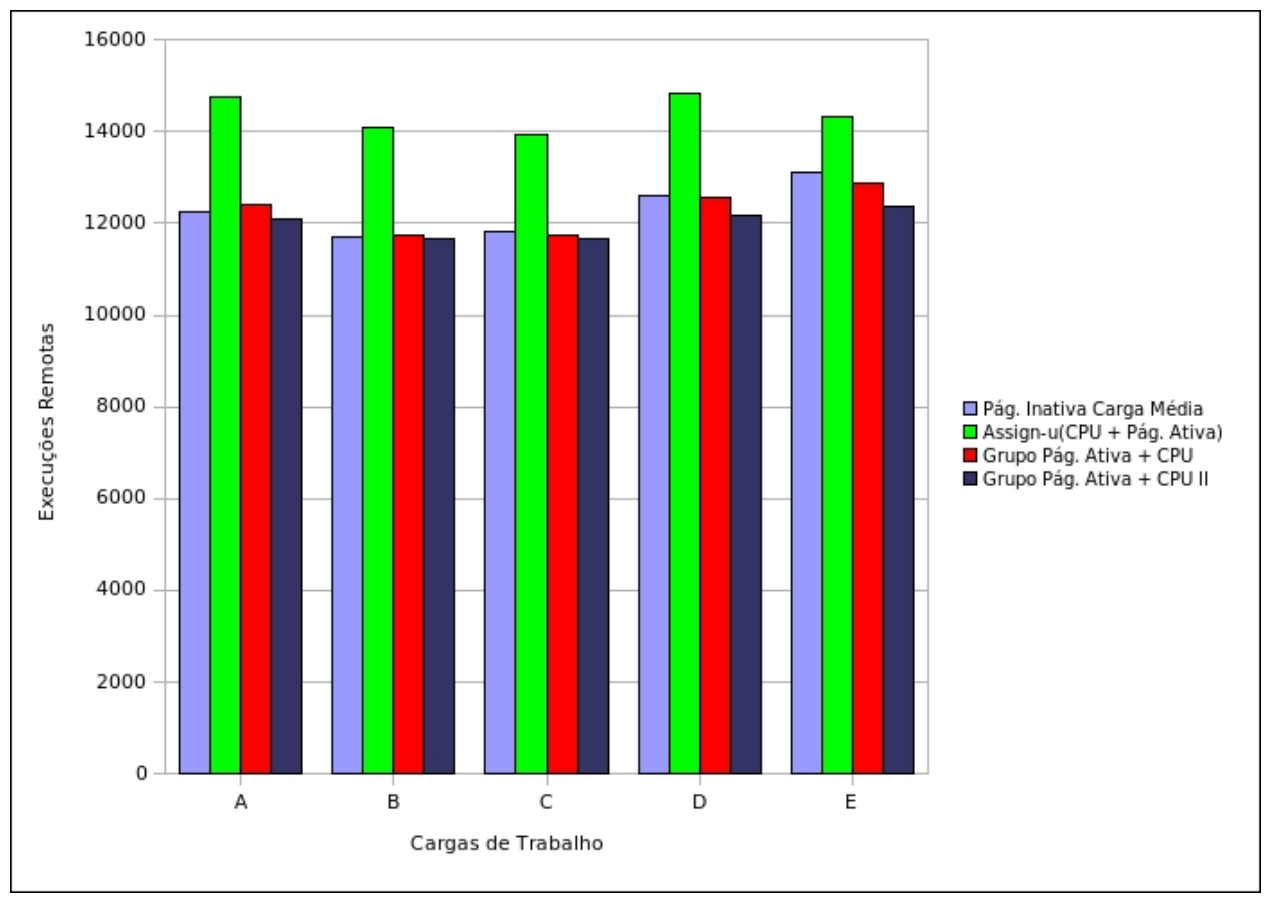

Figura 6.19: Execuções remotas executadas na "Plataforma 1", ao utilizar as políticas baseadas em índices de memória.

com as políticas que não utilizam o desvio padrão.

Assim como na "Plataforma 1", ao reduzir a quantidade de execuções remotas, diminuise também o efeito "rajada" nas máquinas com menores quantidades de processos nas filas de prontos.

Ao permitir um melhor balanceamento da quantidade de memória requisitada pelas aplicações, reduz-se a probabilidade de ocorrência de ausências de páginas, como pode ser observado na figura 6.21. Nesse gráfico, foram incluídas as ausências de páginas de todas as políticas avaliadas, com o objetivo de demonstrar que para a carga de trabalho do tipo "D" a política "CPU carga média com DP" apresentou aproximadamente 38,04\% menos ausências de páginas que a política "Pág. inativa carga média", com uma diferença de apenas $2,87 \%$ na perda de desempenho, conforme pode ser observado na tabela 6.8 .

Esse comportamento é explicado pela heterogeneidade presente na capacidade computacional dos processadores, pois, como a quantidade de memória solicitada na carga "D" é elevada, o escalonamento baseado na fila de CPU, evitando-se as execuções remotas em excesso, ocasionam um balanceamento da memória semelhante ao obtido pela política "Pág. inativa carga média".

Ao analisar somente a quantidade de páginas inativas, a política "Pág. inativas carga média" acumula processos nas máquinas equipadas com processadores de baixa capacidade computacional, levando a ocorrências de ausências de páginas, aumentando a perda de desempenho ao analisar as cargas entre "A" e "D", uma vez que a política "Pág. inativa 


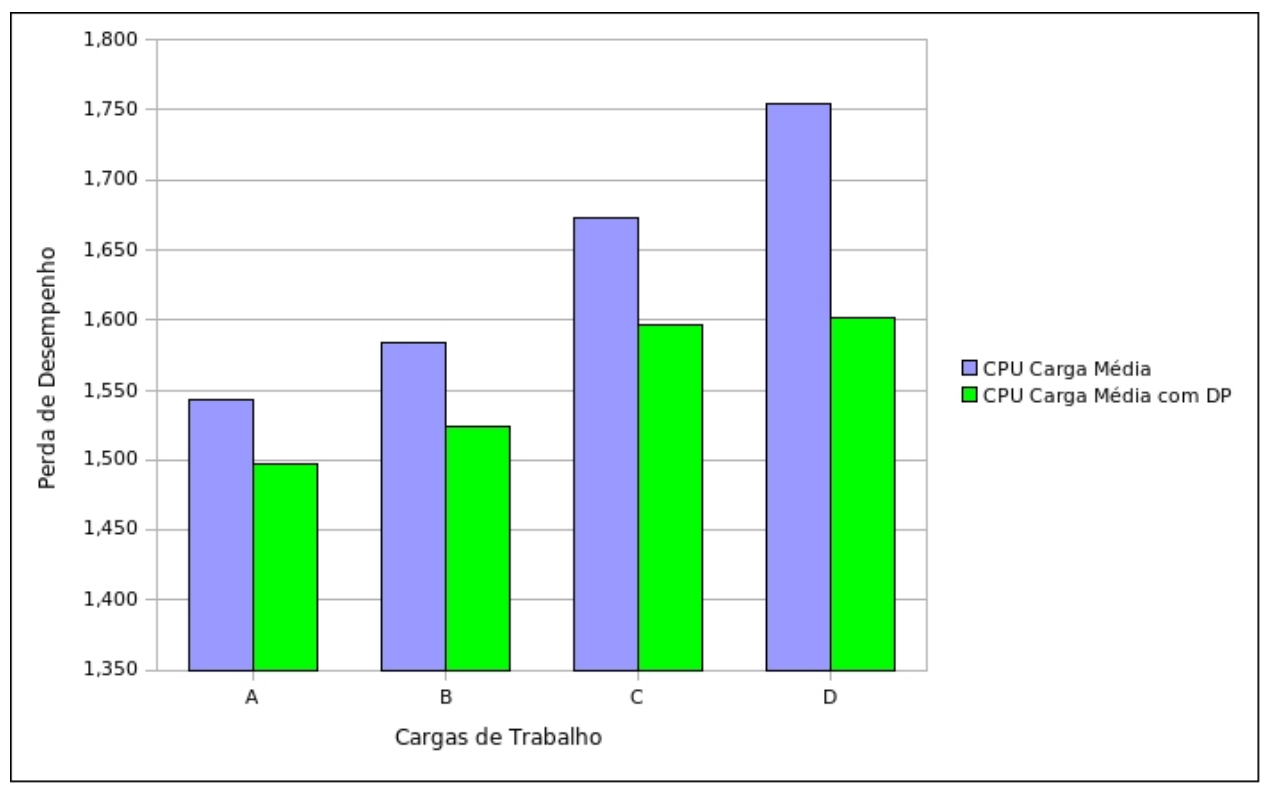

Figura 6.20: Perdas de desempenho sofridas pelas aplicações na "Plataforma 2", ao utilizar as políticas baseadas, unicamente, na fila de prontos.

carga média", assim como as baseadas em CPU, não foi capaz de evitar o estado de trashing para a carga de trabalho "E".

O fato descrito acima pode ser observado na figura 6.22, que apresenta as perdas de desempenho sofridas pelas políticas "CPU carga média com DP" e "Pág. inativa carga média". A linha horizontal superior demonstra a média das perdas de desempenho sofridas pelas tarefas ao serem balanceadas pela política baseada em CPU. Já a linha horizontal inferior, denota a médias das perdas de desempenho sofridas pelos processos ao serem balanceados pela política baseada unicamente na quantidade de páginas inativas.

Analisando-se o gráfico da figura 6.22 é possível observar que os coeficientes angulares, $\alpha$, entre as semi-retas, obtidas ao unirem-se os resultados da política "CPU carga média com DP" à reta horizontal, são inferiores aos obtidos pela política "Pág. inativa carga média". Isto permite concluir que a política baseada em CPU, aqui analisada, apresenta incrementos menores na perda de desempenho, ao sair de uma carga de trabalho em direção à outra, indicando que para plataformas com heterogeneidade de CPU, analisar apenas índices de memória pode levar o sistema ao estado de trashing mais rapidamente que aquelas políticas que analisam apenas índices de CPU, desde que estas evitem a quantidade excessiva de execuções remotas.

Ao comparar os resultados obtidos nas plataformas 1 e 2, por ambas as políticas baseadas em CPU, percebe-se que a heterogeneidade de CPU impõe para o sistema uma perda de desempenho extra, proveniente da distribuição desigual entre os processos, uma vez que processadores mais lentos deveriam receber menos processos, pois, uma máquina muito potente processa um dado processo em um intervalo de tempo menor, se comparado 


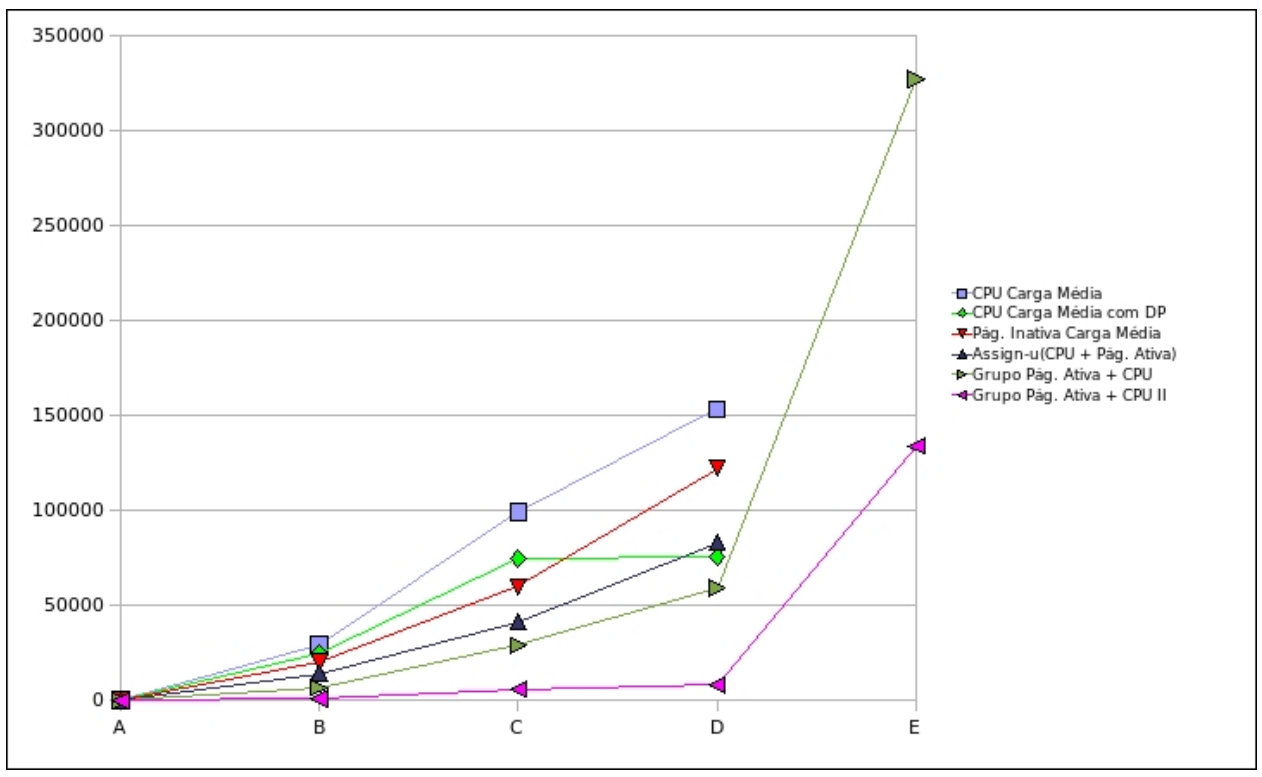

Figura 6.21: Ausência de páginas sofridas pelas aplicações na "Plataforma 2".

a uma máquina com menor capacidade computacional, executando o mesmo processo.

Como as políticas analisadas não detectam a heterogeneidade da plataforma, todas as máquinas do sistema são tratadas de maneira igual. Assim, as máquinas com processadores inferiores tendem a receber a mesma quantidade de processos que as máquinas com processadores mais velozes.

Apesar dos fatos apresentados, ao analisar as tabelas com os valores reais das médias obtidas, tanto na "Plataforma 1", quanto na "Plataforma 2", percebe-se que a política que utiliza o desvio padrão em sua composição, apresenta variações menores que aqueles obtidos pela política "CPU carga média", entre a razão dos resultados obtidos nas plataformas 1 e 2 para as cargas "C" e "D".

Ao executar a carga "D" na "Plataforma 2", ocorreu um aumento de 3,43\% nas perdas de desempenho sofridas pelas aplicações, se comparado com a "Plataforma 1", utilizando a política "CPU carga média com DP". Para a outra política baseada em CPU, porém sem considerar o desvio padrão, esse aumento foi de 7,35\%.

Ao contrário, para as cargas com baixa utilização de memória, "A" e "B", a política "CPU carga média" apresentou variações menores ao se compararem as perdas de desempenho nas plataformas 1 e 2, apresentando uma variação de apenas 1,61\% nos resultados para a carga "A", enquanto que, usando o desvio padrão a variação foi de $3,54 \%$.

No entanto, as razões obtidas pela política "CPU carga média com DP" tendem a ser mais estáveis que as apresentadas pela outra política que utiliza apenas índice de CPU, uma vez que a diferença entre o valor máximo e mínimo, utilizando o desvio padrão, foi de 1,82, enquanto que essa mesma diferença para a política "CPU carga média" foi de 


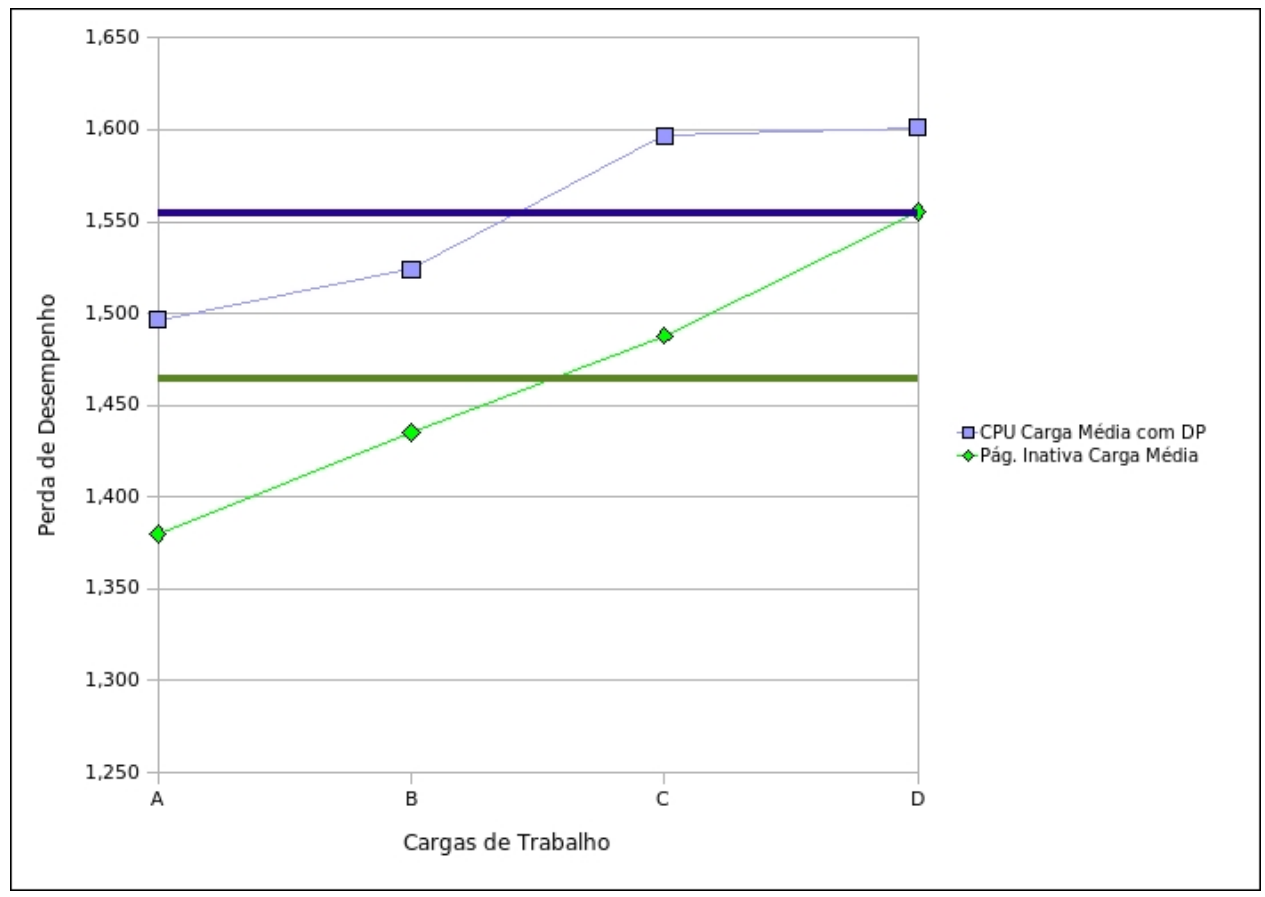

Figura 6.22: Comparação entre as perdas de desempenho obtidas, na "Plataforma 2", pelas política "CPU carga média com DP" e a política "Pág. inativa carga média".

5,74, mostrando que utilizar o desvio padrão torna a política mais estável, reduzindo os impactos causados devido à heterogeneidade de CPU.

Para a "Plataforma 2", as políticas propostas neste trabalho, e que utilizam informações de CPU e memória, apresentaram melhores resultados que as discutidas anteriormente, como é possível visualizar no gráfico da figura 6.23.

Ao analisar o gráfico, nota-se que a política "Assign-u(CPU + Pág. ativa)" apresenta melhores resultados que a política "Pág. inativa carga média", para todas as cargas, com excessão da carga "C", em que houve sobreposição da média de uma política, com o intervalo de confiança da outra, impossibilitando afirmar qual a melhor alternativa. Para definir qual a melhor política para essa carga, poderiam ser realizadas mais algumas simulações, porém, a diferença entre as média seria de aproximadamente 1,61\%, apresentando comportamento semelhante às cargas "A" e "B".

Para as demais cargas, a política baseada no algoritmo Assign-u chegou a apresentar ganhos de 4,44\%, ao comparar a perda de desempenho obtida pela política na carga "D" com o resultado obtido pela política de referência baseada em memória. Porém, para cargas predominantemente $C P U$-bound, a diferença foi de apenas $0,8 \%$ e $1,32 \%$ para as cargas "A" e "B", respectivamente.

Esses valores poderiam levar à conclusão, errada, que não justificaria optar pela utilização da política "Assign-u(CPU + Pág. ativa)" para cargas com pequenas solicitações de memória. Porém, deve-se observar na figura 6.21 que a quantidade de ausências de 


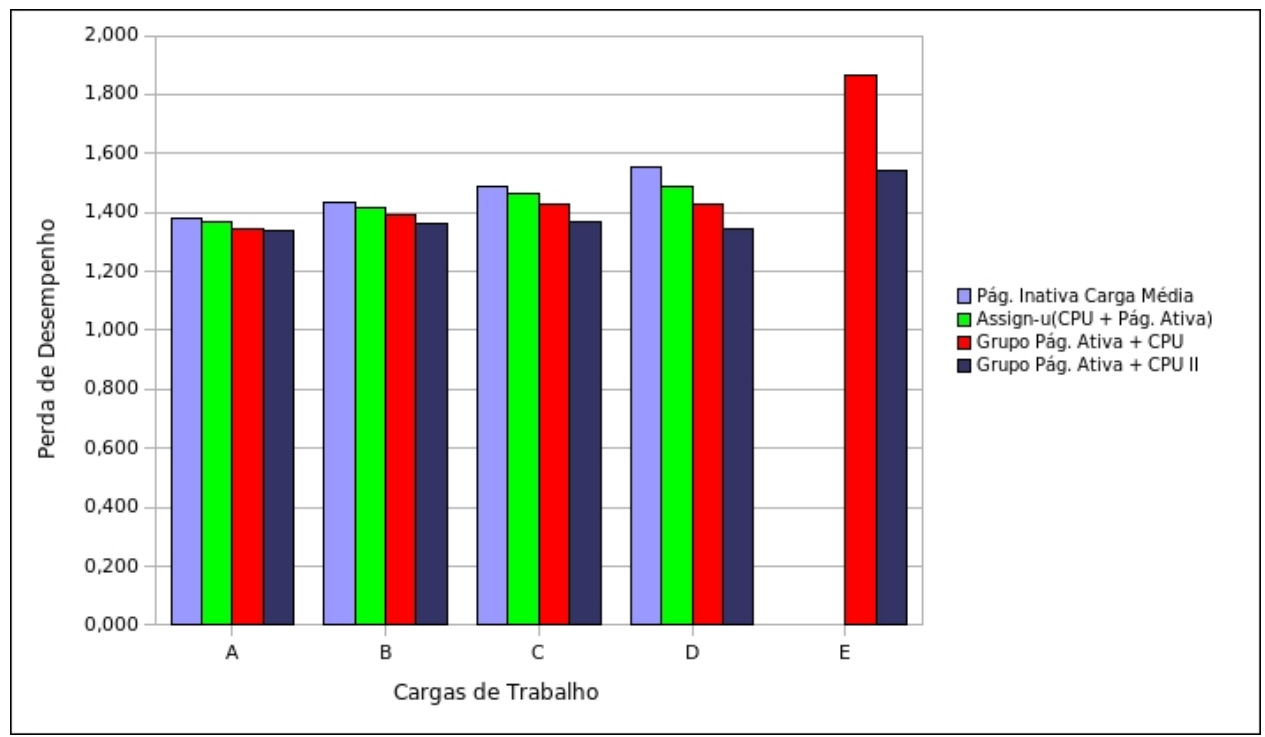

Figura 6.23: Perdas de desempenho sofridas pelos processos, na "Plataforma 2", ao serem escalonados pelas políticas que utilizam informações de memória.

páginas ocasionadas pelo balanceamento da política que utiliza o algoritmo Assign-u, são reduzidas em até $31,9 \%$ com a carga "D" e no mínimo em $29,61 \%$ para a carga "B", retardando a obtenção do estado de trashing, se comparada à política de referência, caso a freqüência de submissões seja aumentada.

Da mesma forma, as políticas baseadas em grupo apresentam-se superiores à "Pág. inativa carga média", em todas as cargas. Sendo também superior à política baseada no algoritmo Assign-u.

A redução da perda de desempenho, comparando as políticas baseadas em grupo com a política de referência baseada em memória, aumenta entre as cargas "A" e "D". Os ganhos com referência à carga "E" não puderam ser obtidos, uma vez que somente as políticas baseadas em grupo conseguiram evitar que o sistema entrasse em estado de trashing.

Ao comparar-se com a política de referência baseada em memória, a política "Grupo pág. ativa + CPU" apresentou ganhos entre 2,75\% e 8,23\% para as cargas variando entre "A" e "D", respectivamente. Já a política "Grupo pág. ativa + CPU II" apresentou ganhos entre $3,19 \%$ e $13,63 \%$, para as mesmas cargas de trabalho e para a mesma política de referência.

Ao analisar o gráfico 6.21 nota-se que as políticas baseadas em grupo são as que menos sofrem ausências de páginas, sendo que a política "Grupo pág. ativa + CPU II" chegou a apresentar 93,54\% menos ausências de páginas quando comparada às sofridas com a utilização da política "Pág. inativa carga média". Essa política apresentou reduções superiores a $90 \%$ para todas as cargas, justificando sua capacidade em executar a carga "E". 
A política "Grupo pág. ativa + CPU" também apresentou poucas ausências de páginas, porém, não foi tão eficiente quanto a política "Grupo pág. ativa + CPU II", apresentando reduções na quantidade de ausências de páginas entre $51 \%$ e $65 \%$, nas cargas "D" e "B", respectivamente, ao comparar com a política "Pág. inativa carga média".

Os resultados obtidos pela política baseada no algoritmo Assign-u não foram tão satisfatórios quanto aqueles apresentados pelas políticas baseadas em grupo, pois o tamanho da fila de prontos e a quantidade de páginas ativas possuem o mesmo peso no momento do escalonamento, ao contrário das políticas baseadas em grupo, em que as máquinas com muitas páginas ativas são retiradas da seleção.

Essa característica leva a política "Assign-u(CPU + Pág. ativa)" a realizar uma grande quantidade de execuções remotas, como acontece com as políticas que utilizam unicamente índices de CPU. Esse comportamento pode ser visualizado na figura 6.24.

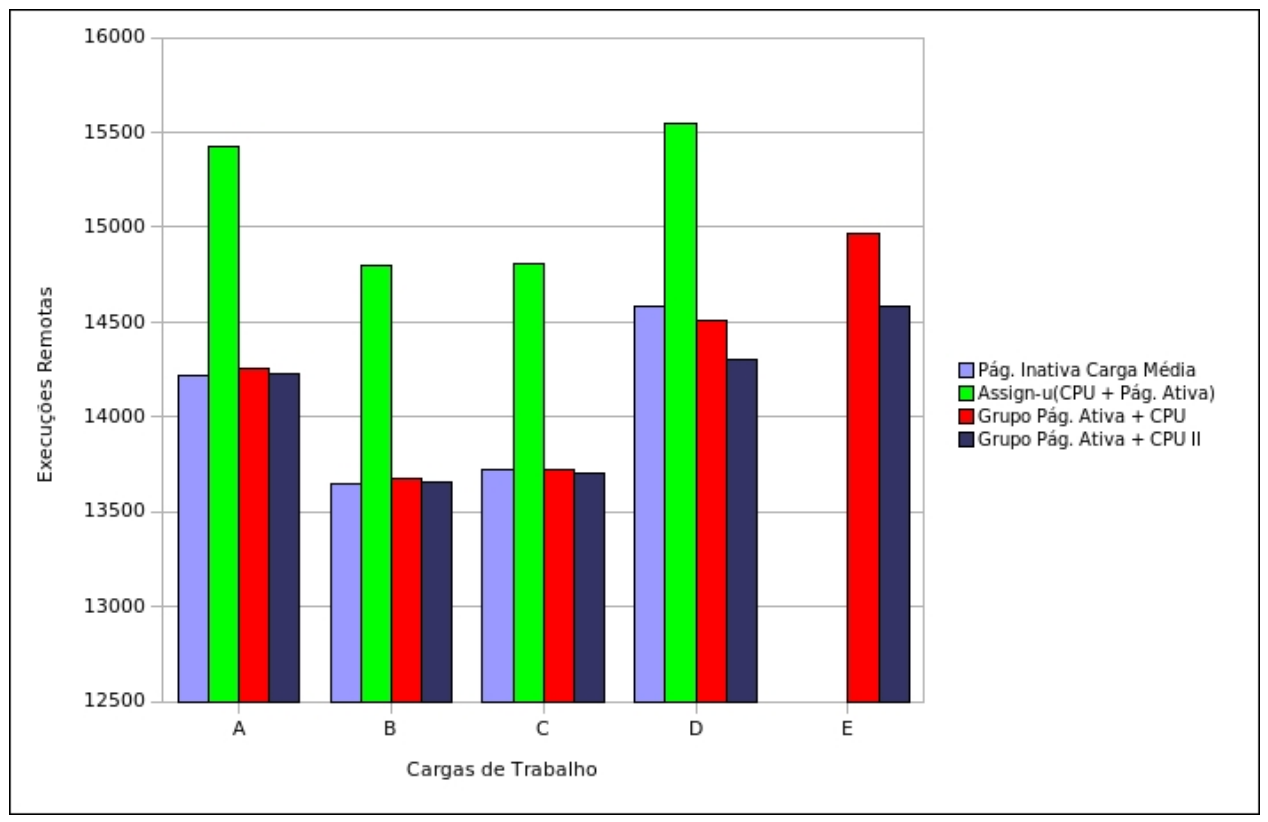

Figura 6.24: Execuções remotas realizadas na "Plataforma 2", ao usar as políticas baseadas em índices de memória.

Na média, a política baseada no algoritmo Assign-u executa aproximadamente mil execuções remotas a mais que a política de referência, não realizando o balanceamento da memória de maneira tão eficiente quanto aos realizados pelas políticas baseadas em grupo.

Assim como as demais políticas, as baseadas em grupo também apresentaram perda de desempenho ao comparar se os resultados obtidos na "Plataforma 2" e aqueles obtidos na "Plataforma 1". Essa redução de desempenho ficou entre $6 \%$ e $7 \%$ para a política "Grupo pág. ativa + CPU II" para as cargas entre "A" e "D". Já para a carga "E", a redução foi de aproximadamente $13 \%$. Para essa carga, as simulação entraram em estado 
de trashing em $30 \%$ das simulações.

Essa redução, para a política "Grupo pág. ativa + CPU", apresentou uma grande variação, entre $3,8 \%$ para a carga "A" chegando a $15 \%$ para a carga "E". Para a última carga citada, a política aqui analisada conseguiu finalizar apenas $36,66 \%$ das simulações, enfatizando o impacto negativo da heterogeneidade de CPU em situações em que as aplicações solicitam uma grande quantidade de memória, como na carga de trabalho "E".

\subsubsection{Heterogeneidade de memória}

Ao realizar as simulações na "Plataforma 3", tem-se que a política "Pág. inativa carga média" apresenta resultados muito acima das demais políticas, apresentando perda de desempenho entre 4,674 e 8,556, para as cargas "E" e "A", respectivamente. Os demais resultados obtidos para esta política e para as demais, podem ser visualizados na tabela 6.9. Baseado nessas informações, os resultados obtidos pela política "Pág. inativa carga média" serão suprimidos dos gráficos.

É interessante observar que as maiores perdas de desempenho, apresentadas pela política "Pág. inativa carga média", ocorreram em cargas formadas por aplicações predominantemente $C P U$-bound, onde, as aplicações solicitam uma pequena quantidade de memória, levando a política a atribuir uma quantidade elevada de processos nas máquinas que possuem uma grande quantidade de memória DRAM disponível, fazendo, assim, com que o tempo médio na fila de prontos seja extremamente elevado nesses sistemas.

Essa situação merece uma atenção especial pois, para a carga "A" a política não permite nenhuma ocorrência de ausência de página, mas o tempo médio na fila de prontos chega a ser $98,12 \%$ maior que a média de tempo gasto pelos processos com o sistema sendo gerenciado pela política "CPU carga média", que apresenta a maior perda de desempenho após a política "Pág. inativa carga média".

O fato descrito acima pode ser observado no gráfico da figura 6.25, que demonstra a média de tempo gasto pelos processos nas filas de prontos.

Como pode ser observado, o tempo médio na fila de prontos é o principal e, possivelmente, o único, fator responsável pelos resultados ruins obtidos pela política "Pág. inativa carga média", pois a política apresentou um bom gerenciamento da quantidade de ausências de páginas na plataforma.

É possível observar ainda que à medida que as quantidades de memória solicitadas pelas aplicações aumentam, a política consegue reduzir a perda de desempenho, pois o acúmulo de processos, em nós que possuem uma grande quantidade de memória, é amenizado. 


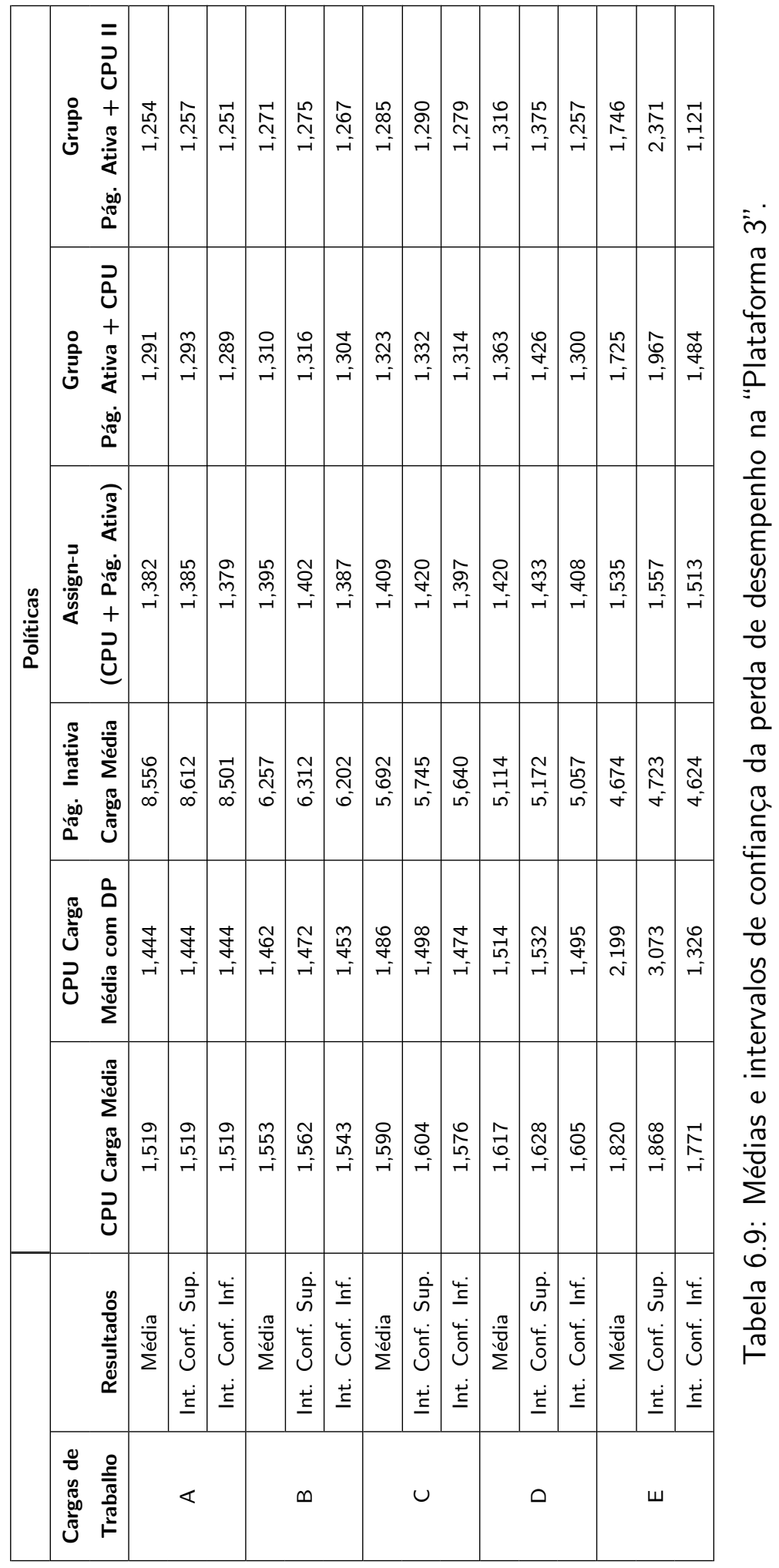




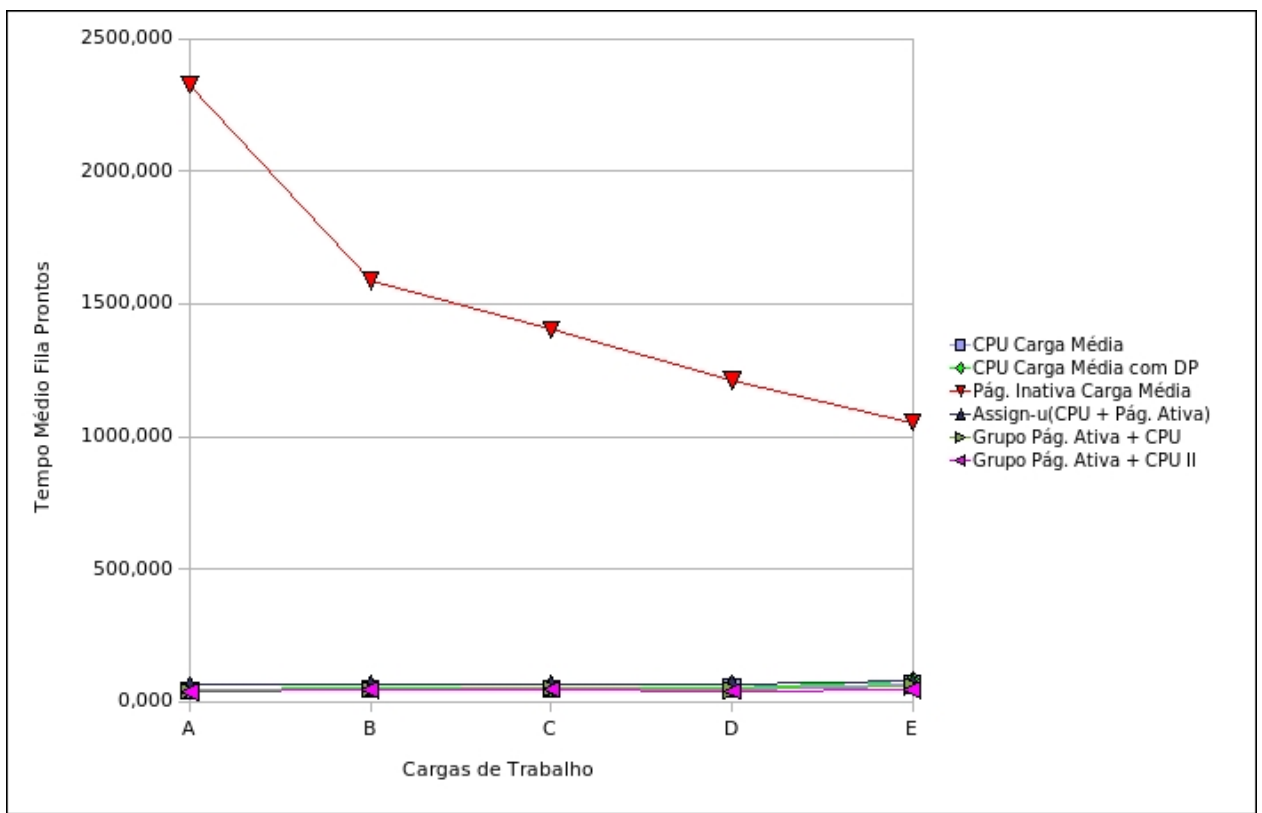

Figura 6.25: Tempo médio gasto na fila de prontos pelos processos na "Plataforma 3".

Na figura 6.26 é possível visualizar as perdas de desempenho sofridas pelas aplicações ao serem balanceadas pelas políticas analisadas neste trabalho. Como mencionado anteriormente, a política "Pág. inativa carga média" não está presente no gráfico, pelos motivos já descritos.

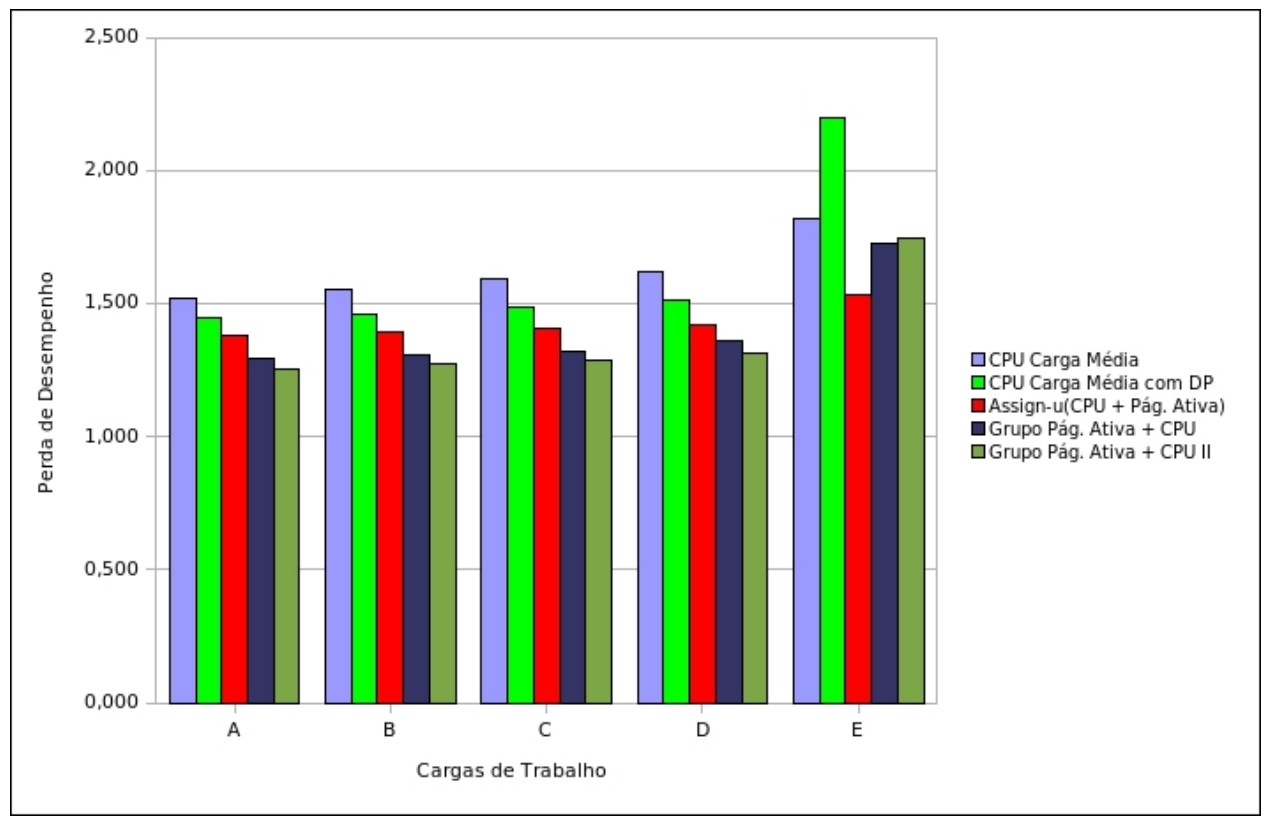

Figura 6.26: Perdas de desempenho sofridas pelos processos na "Plataforma 3".

Conforme pode ser visualizado nesse gráfico, a modificação na política baseada em CPU, "CPU carga média com DP", apresentou reduções nas perdas de desempenho para as cargas variando de "A" até "D", se comparada à política de referência baseada unicamente em CPU. Para a carga "E", apesar da política tradicional apresentar no gráfico um 
resultado melhor, analisando a tabela com os intervalos de confiança, percebe-se que não é possível concluir qual a política, dentre as citadas, que apresentou o melhor resultado para esta carga de trabalho, uma vez que houve sobreposição entre as médias obtidas e os intervalos de confiança.

Essa indefinição é proveniente do grande intervalo de confiança obtido, uma vez que as políticas "CPU carga média" e a "CPU carga média com DP" conseguiram executar apenas $45 \%$ e $35 \%$ das simulações para a carga "E", respectivamente. Assim, percebe-se que para plataformas com heterogeneidades na capacidade de armazenamento da memória principal, para cargas que requerem uma grande quantidade de memória DRAM, a política original, baseada unicamente na fila de prontos, evita o estado de trashing com maior eficiência, se comparada à política que utiliza o desvio padrão.

Para as cargas variando de "A" até "D", a política "CPU carga média com DP" reduziu em até $6,54 \%$ a média da perda de desempenho para a carga "C", cuja redução mínima foi de $4,95 \%$ para a carga "A".

Essa redução das perdas de desempenho fori obtida pela política "CPU carga média com DP" com a redução na quantidade de execuções remotas realizadas, evitando a penalização da plataforma, ao permanecer com uma grande quantidade de processos sendo trafegados pela rede, consumindo tempo desnecessário. Uma comparação entre as quantidades de execuções remotas executadas pode ser visualizada na figura 6.27.

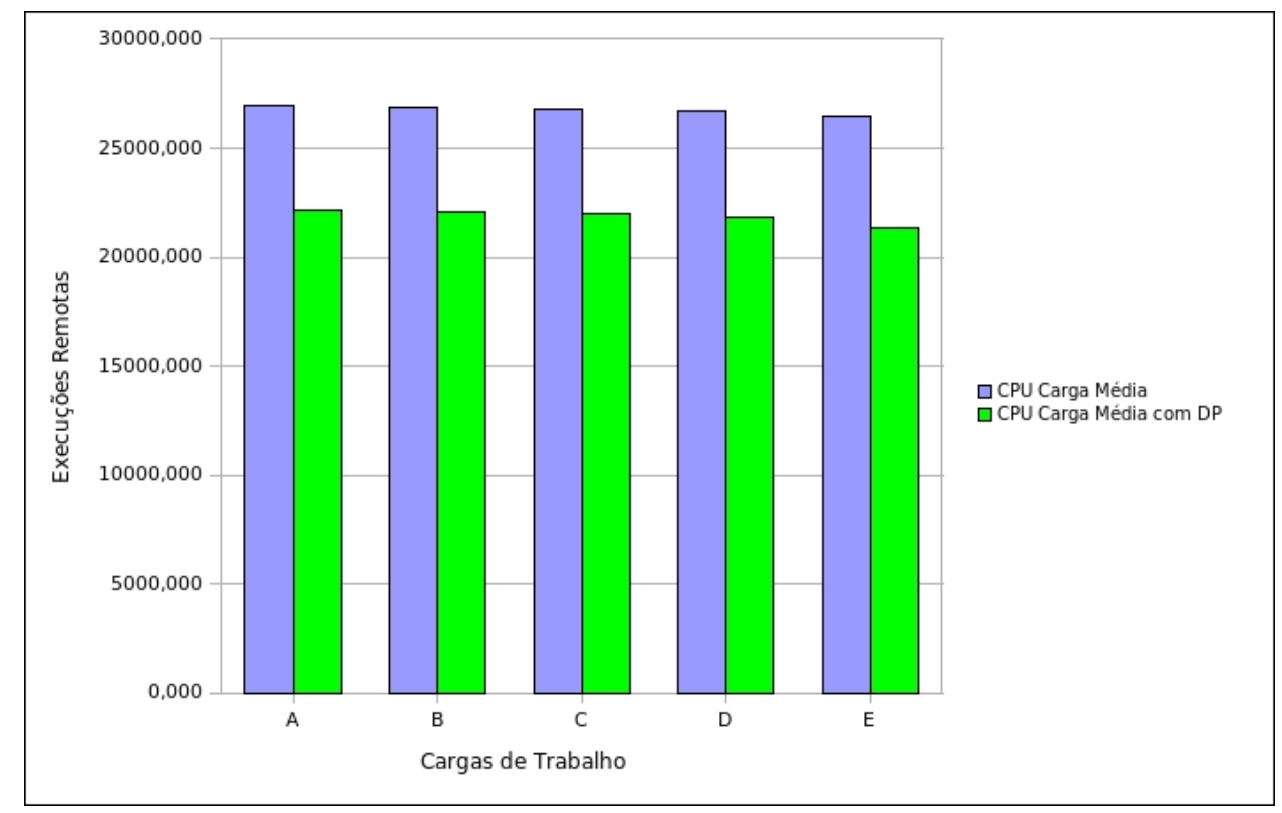

Figura 6.27: Execuções remotas realizadas pelas políticas baseadas em CPU na "Plataforma 3".

Nesse gráfico as reduções das quantidades de execuções remotas obtidas pela política "CPU carga média com DP" variaram entre 17,63\% e 18,17\%. Essa redução na quantidade de execuções remotas permitiu que uma maior quantidade de processos fossem 
executados localmente, sem serem enviados para execução remota, causando um melhor balanceamento da memória e reduzindo o acúmulo de processos nas máquinas com menores quantidades de memória DRAM.

Esse balanceamento da memória reduziu a quantidade de ausências de páginas sofridas pelos processos, permitindo a redução da perda de desempenho obtida pela política "CPU carga média com DP". As quantidades de ausências de páginas sofridas sob as duas políticas baseadas em CPU podem ser visualizadas na figura 6.28

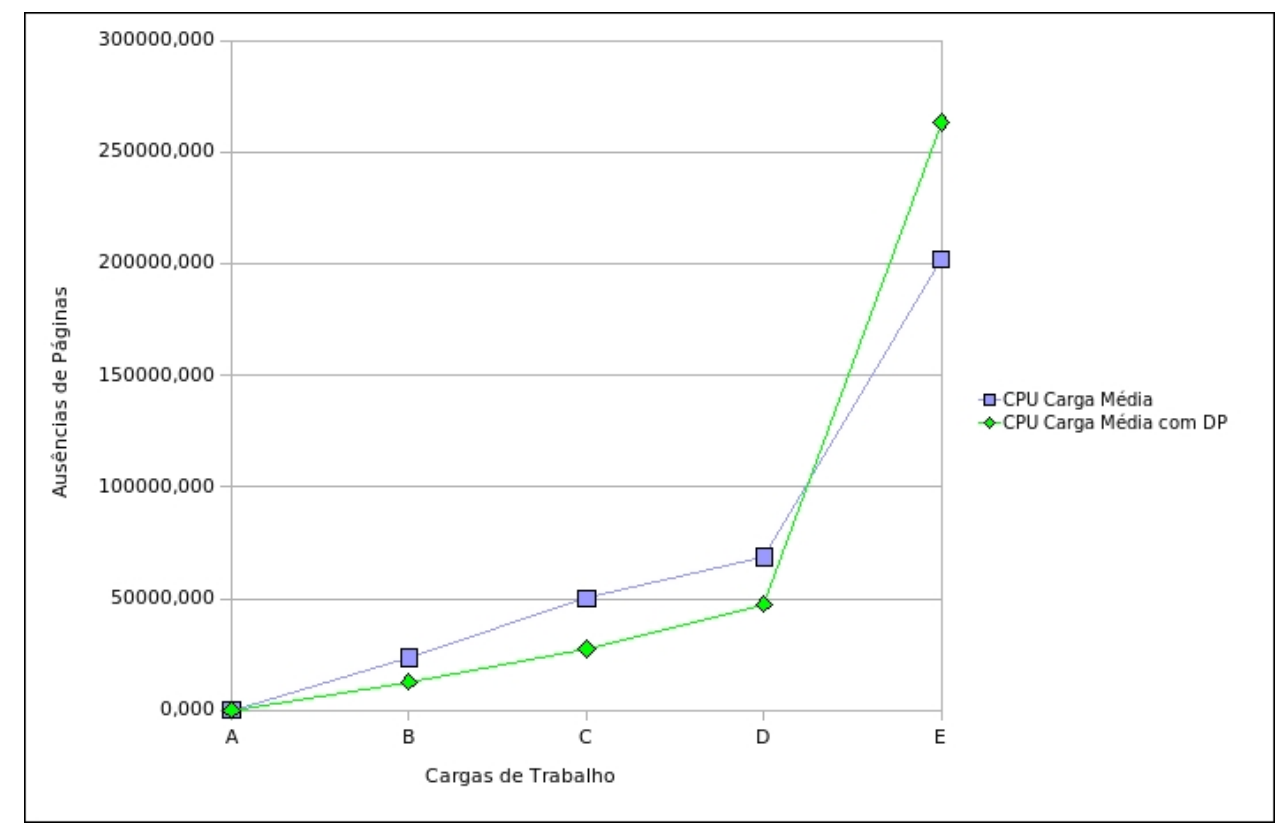

Figura 6.28: Ausências de páginas sofridas pelos processos ao serem utilizadas as políticas baseadas em índices de CPU na "Plataforma 3".

As reduções nas quantidades de ausências de páginas obtidas, ao utilizar o desvio padrão, variaram entre $30,50 \%$ e $45,35 \%$ para as cargas "D" e "C", respectivamente. A maior redução foi observada na carga "C", que é a mesma carga em que a política "CPU carga média com DP" apresentou a maior diferença na perda de desempenho, ao ser comparada com a política de referência.

Esse fato indica que a redução na quantidade de ausências de páginas, juntamente com a economia de tempo obtida pelas reduções nas quantidades de execuções remotas, levaram a política, modificada neste trabalho, a resultados melhores para a "Plataforma $3 "$.

Apesar dessa melhoria dos resultados, as novas políticas propostas, baseadas em CPU e memória, apresentaram-se ainda mais eficientes, como pode ser observado no gráfico 6.26 .

Ao analisar o gráfico da figura 6.26, juntamente com a tabela com os valores das médias e dos intervalos de confiança, conclui-se que para as cargas entre "A" e "C" os 
resultados indicam que a política "Grupo pág. ativa + CPU II" é superior às demais, sem retrições. Para essas mesmas cargas, à política "Grupo pág. ativa + CPU” é superior a política baseada no algoritmo Assign-u.

A política "Grupo pág. ativa + CPU" apresentou reduções entre 6,09\% e 7,58\%, para as cargas "B" e "A", respectivamente. Para a segunda política baseada em grupo, as diferenças variaram entre 7,32\% e 9,26, para as cargas "D" e "A", respectivamente. Esses valores indicam que à medida que a carga passa de "A" para "E", variando entre aplicações basicamente $C P U$-bound, para uma sobrecarga de aplicações memory-itensive, a política "Assign-u(CPU + Pág. ativa)" tende a ser melhor.

Essa hipótese, levantada no parágrafo anterior, pode ser confirmada pelo fato de não haver definição entre qual a melhor política entre "Grupo pág. ativa + CPU" e "Assignu(CPU + Pág. ativa)" para a carga "D" e pela indefinição para a carga "E", em que nenhuma das três políticas que utilizam índices de memória e CPU podem ser indicadas como aquela que apresentou o melhor resultado, uma vez que há sobreposições entre as médias e os intervalos de confiança.

No entanto, para a carga "E", a política baseada no algoritmo Assign-u foi a única a executar $100 \%$ das simulações, evitando que o sistema entrasse em estado de trashing em todas elas. Já as políticas baseadas em grupo conseguiram evitar o estado de trashing em apenas 53,33\% e 46,67\%, onde a política "Grupo pág. ativa + CPU" foi superior à "Grupo pág. ativa + CPU II".

Essa tendência e os resultados discutidos anteriormente podem ser explicados analisando-se as quantidades de ausências de páginas ocorridas e também a quantidade de execuções remotas realizadas. Na figura 6.29 é apresentado um gráfico das ausências de páginas sofridas na plataforma ao utilizar as políticas que utilizam índices de CPU e memória.

Ao analisar o gráfico das ausências de páginas tem-se que, para as cargas "A", "B" e "C" a política "Grupo pág. ativa + CPU II" sofre menos ausências de páginas, se comparada às demais, devido ao melhor balanceamento de memória realizado e do balanceamento indireto do tamanho da fila de prontos da CPU entre as máquinas com maiores capacidades de memória.

Esse mesmo comportamento pode ser verificado na quantidade de execuções remotas, presentes na figura 6.30. Para as cargas descritas, a segunda política baseada em grupo apresenta-se mais conservadora no momento de decidir se deve, ou não, enviar um processo para execução remota. Somando-se os tempos economizados com as pequenas ausências de páginas e a redução no tempo gasto com as execuções remotas, a política "Grupo pág. ativa + CPU II" apresentou melhores resultados, se comparado aos obtidos pelas demais políticas. 


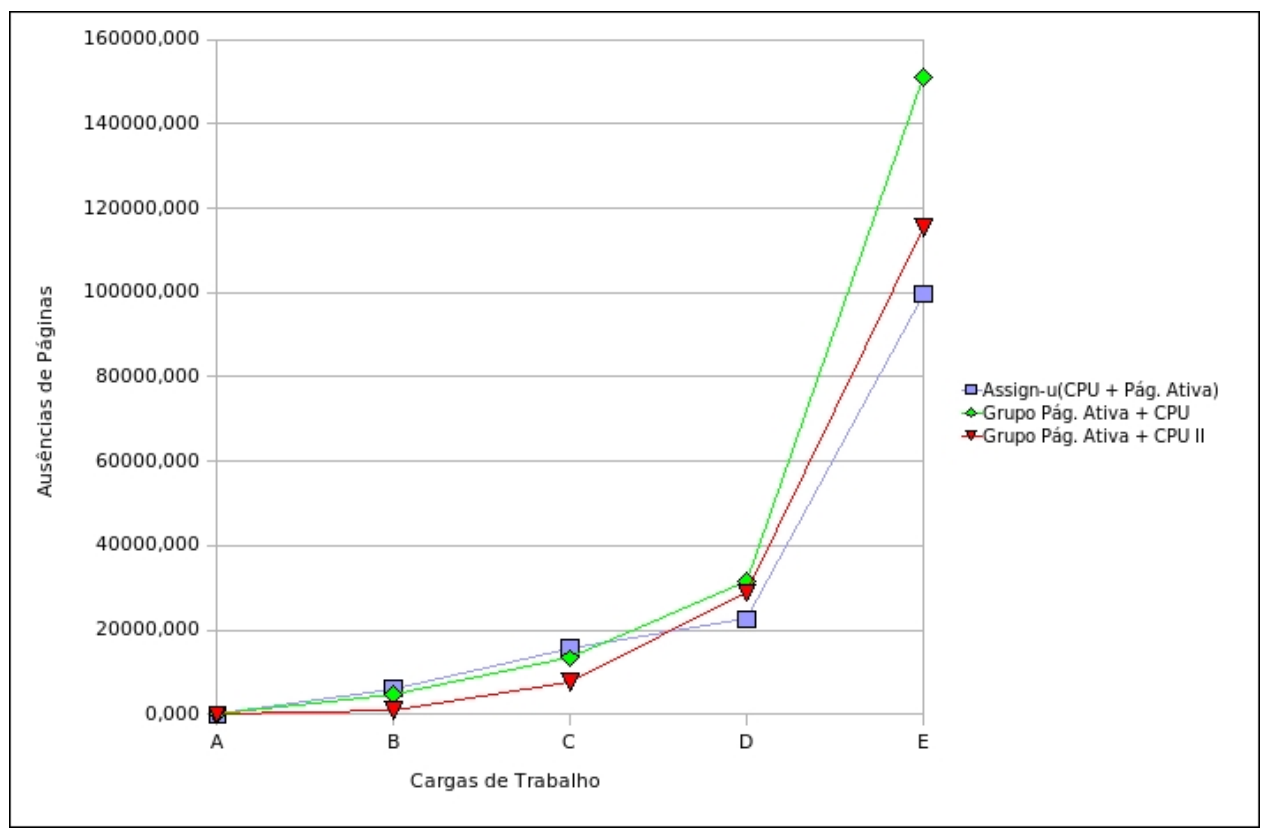

Figura 6.29: Ausências de páginas sofridas pelos processos ao serem utilizadas as políticas baseadas em CPU e memória na "Plataforma 3".

Além disso, é possível perceber que em plataformas com heterogeneidade de memória, utilizar peso maior para índices de memória prejudica o escalonamento para o cenário de cargas com presença de aplicações que exigem uma grande quantidade de memória.

Durante a primeira etapa realizada pelas políticas baseadas em grupo, as máquinas com menores quantidades de páginas ativas são eliminadas do grupo de seleção. Assim, as máquinas com pouca quantidade de memória DRAM somente entrarão no grupo quando as demais estiverem com uma grande quantidade de processos em execução, aumentando consideravelmente a quantidade de ausências de páginas.

Esse comportamento pode ser analisado ao observar que para a carga "D" e "E" os processos sofrem menos ausências de páginas ao serem escalonados pela política "Assignu(CPU + Pág. ativa)" do que pela política "Grupo pág. ativa + CPU II", caracterizando uma inversão de comportamento, já que para as cargas variando entre "A" e "C", a política "Grupo pág. ativa + CPU II" evitou que os processos sofressem ausências de páginas de maneira mais eficiente que a política baseada no algoritmo Assign-u

Essa inversão no gráfico da figura 6.29, na carga "D", é devida à redução do crescimento da quantidade de ausências de páginas sofridas pelos processos entre uma carga de trabalho o outra, ao serem escalonados com a política "Assign-u(CPU + Pág. ativa)". Entre as cargas "B" e "C" houve um aumento de 60,45\% na quantidade de ausências de páginas ocorridas. Já ao analisar a diferença entre as cargas "C" e "D", percebe-se que o aumento de ausências de páginas passou para apenas 31,27\%.

Ao contrário, a política "Grupo pág. ativa + CPU II" apresentou aumento de 87,04\% 


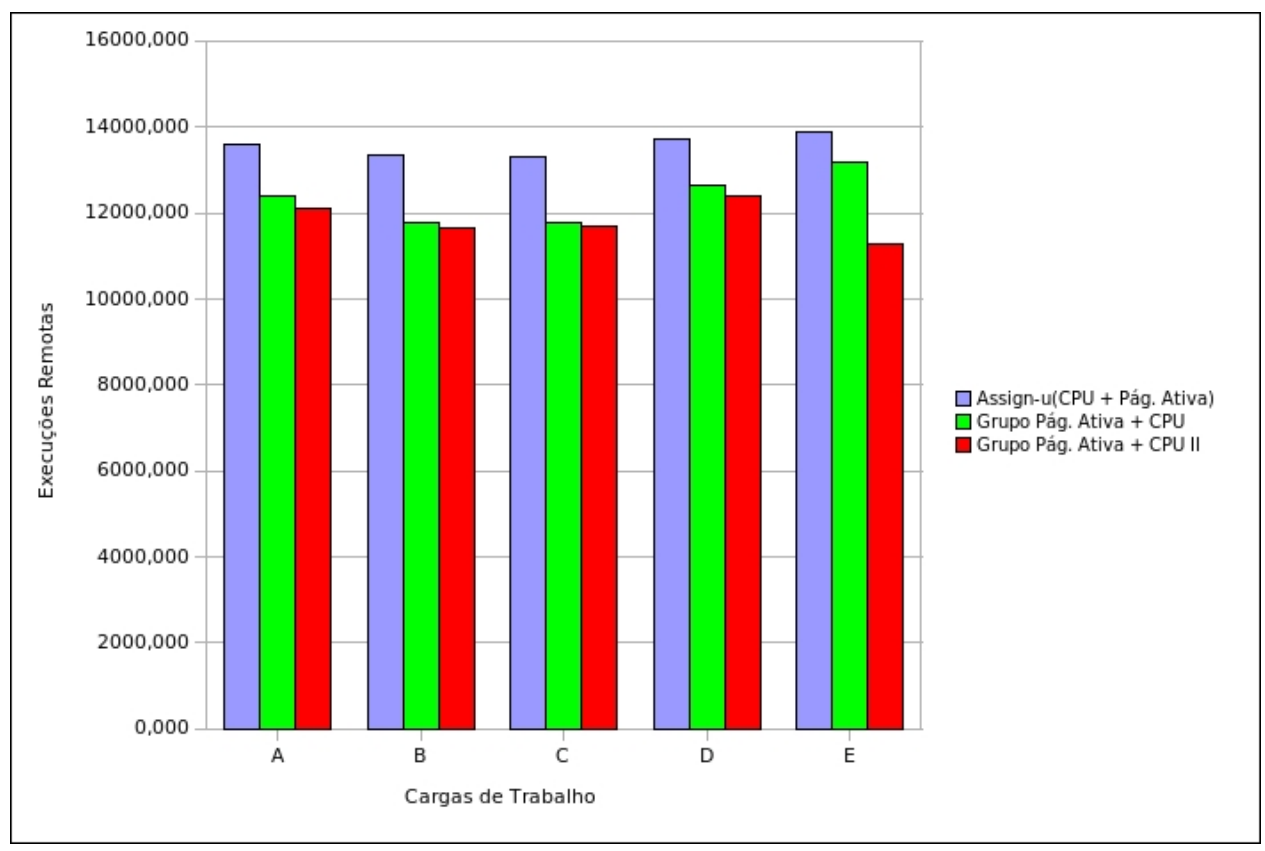

Figura 6.30: Execuções remotas realizadas pelas políticas baseadas em CPU e memória na "Plataforma 3".

ao se analisar as ausências de páginas ocorridas nas cargas "B" e "C" e 73,78\% para as cargas "C" e "D", apresentando uma redução de apenas 15,23\% enquanto a política baseada no algoritmo Assign-u apresentou uma diferença de 51,73\%, indicando uma redução maior que o dobro da obtida pela política "Grupo pág. ativa + CPU".

Essa análise indica que, para ambientes em que há heterogeneidade de memória e a presença massiva de aplicações memory-itensive com necessidade de grandes quantidades de memória, as políticas que realizam o balanceamento utilizando pesos iguais para índices de CPU e memória são mais eficientes, pois evitam o acúmulo de processos em máquinas com maiores capacidades de armazenamento principal.

Porém, em ambientes com heterogeneidade de memória e com cargas dominantemente $C P U$-bound, as políticas baseadas em grupo foram superiores, pois causam menos ausências de páginas e realizam menos execuções remotas, economizando o tempo gasto na rede.

É importante observar também que a heterogeneidade de memória é extremamente prejudicial para sistemas de cluster, ao utilizarem-se políticas que não reconhecem essa heterogeneidade. Essa afirmação é comprovada por não ter sido possível manter a quantidade total de memória DRAM no cluster ao estudar a "Plataforma3", sendo que esta apresenta uma quantidade de memória DRAM 48,94\% maior que a presente na "Plataforma 1". Ao utilizar a mesma capacidade de armazenamento todas as políticas permitiam que o sistema entrasse em estado de trashing, normalmente, ao executar a carga "C". 


\subsubsection{Heterogeneidade de disco}

Assim como nas demais plataformas, na "Plataforma 4", a política "CPU carga média com DP" apresentou ganhos de desempenho ao ser comparada à política "CPU carga média". Os valores obtidos para as perdas de desempenho podem ser visualizados no gráfico da figura 6.31 .

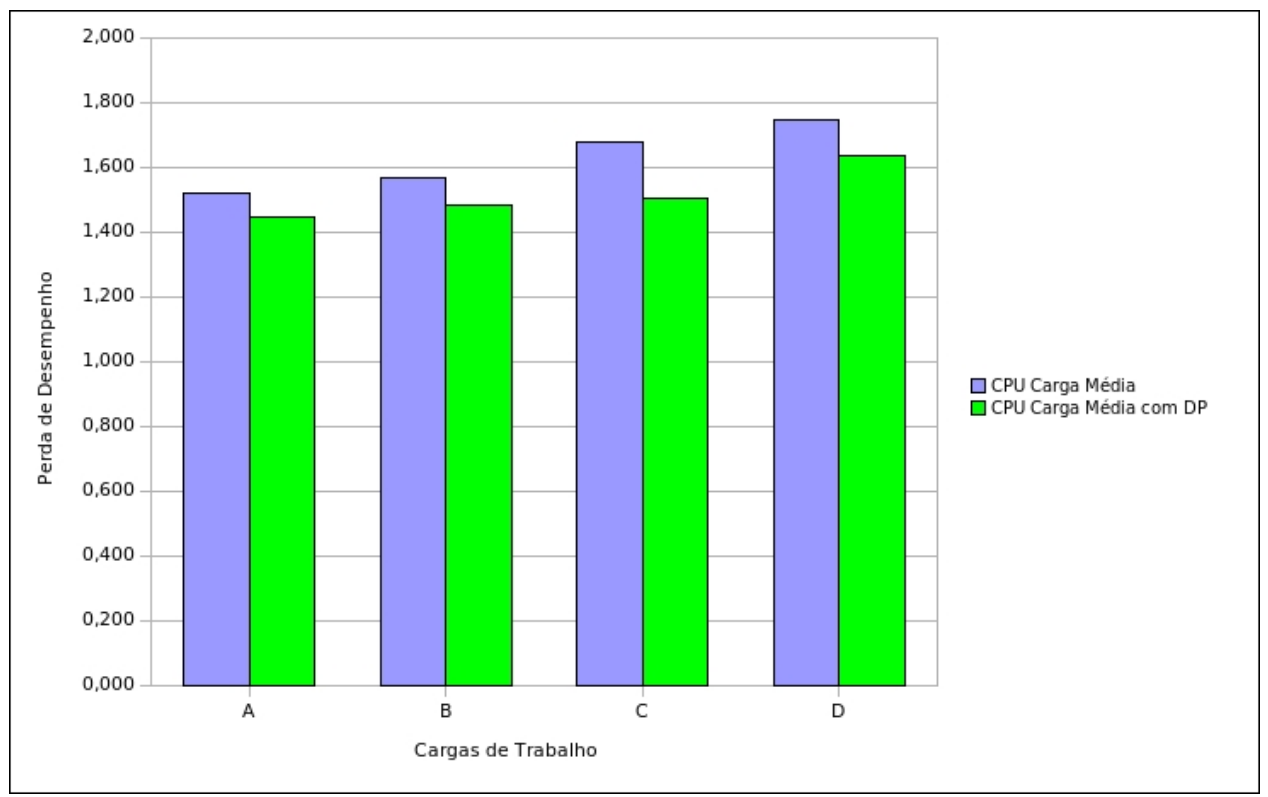

Figura 6.31: Perdas de desempenho sofridas pelos processos na "Plataforma 4", sob o escalonamento das políticas baseadas unicamente em CPU.

Através da tabela 6.10 é possível verificar que os resultados apresentados pela política "CPU carga média com DP" supera, em todas as cargas, a política "CPU carga média". Em nenhuma carga há sobreposição das médias e dos intervalos de confiança.

A maior redução na perda de desempenho foi obtida na carga "C", com uma redução de 10,37\%, enquanto a menor redução foi obtida na carga "A", com 4,94\%. É interessante observar ainda que para a carga "D", a redução da perda de desempenho foi de 6,58\%, inferior à redução obtida com a carga "C". Esse comportamento ocorreu devido ao menor número de execuções remotas executas.

Na carga "C", a política "CPU carga média com DP" executou 24,80\% menos execuções remotas, se comparada à quantidade de execuções remotas realizadas pela política de referência. Já para a carga "D" essa diferença na quantidade de execuções remotas foi de $19,30 \%$.

As quantidades de execuções remotas executadas por cada política podem ser visualizadas na figura 6.32. Ao analisar esse gráfico, observa-se que na carga "C", a política "CPU carga média com DP" apresenta uma redução desproporcional às obtidas nas demais cargas. Esse comportamento deve-se ao fato da carga "C" apresentar uma maior quantidade 


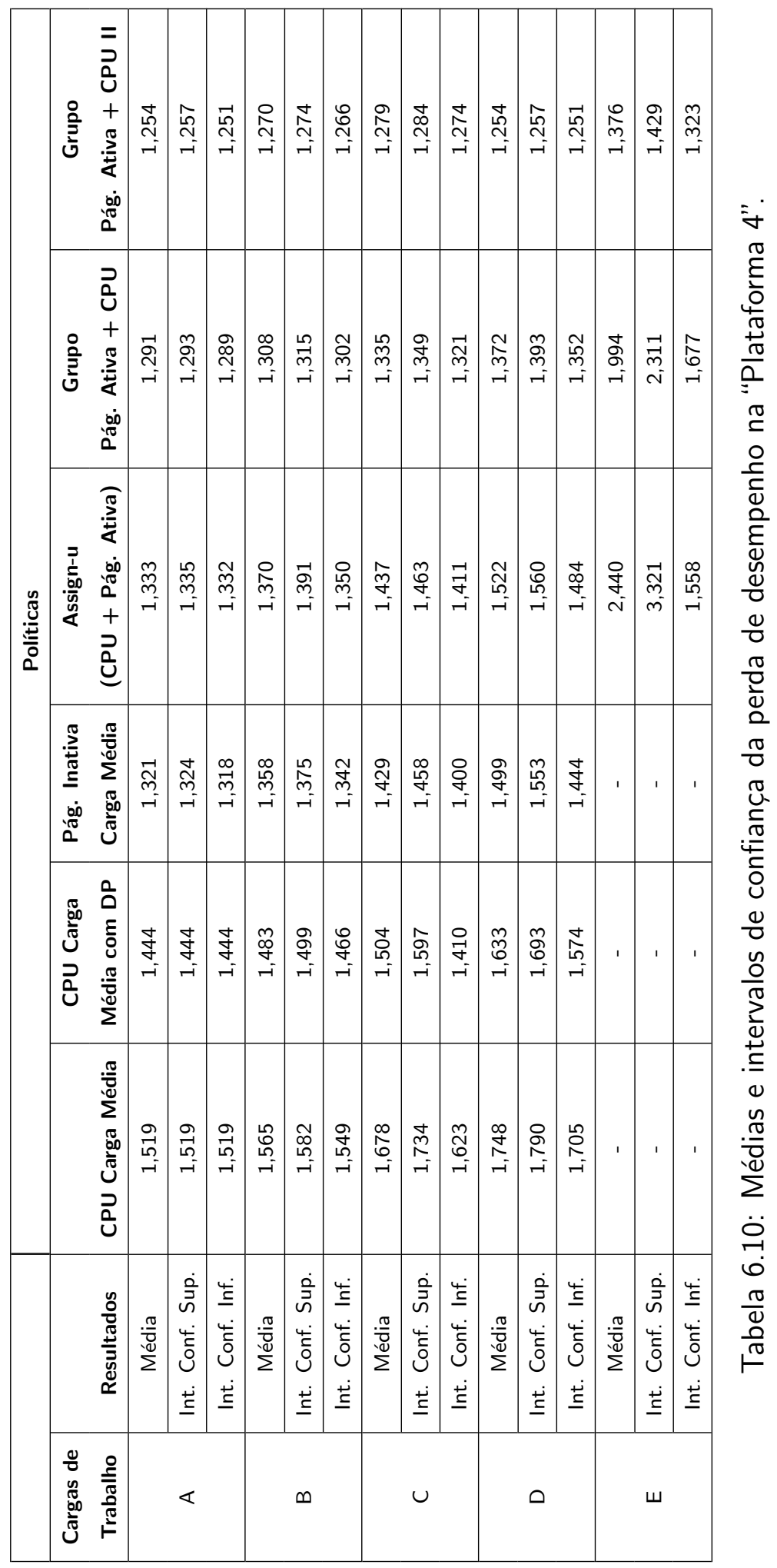


de processos cujas quantidades de memórias solicitadas estão próximas ao valor definido por $p$, na distribuição de Pareto, enquanto para as cargas "B" e "D" poucos processos solicitam quantidades de memória próximas a $p$. Essa diferença pode ser analisada nas figuras 6.2 e 6.4 .

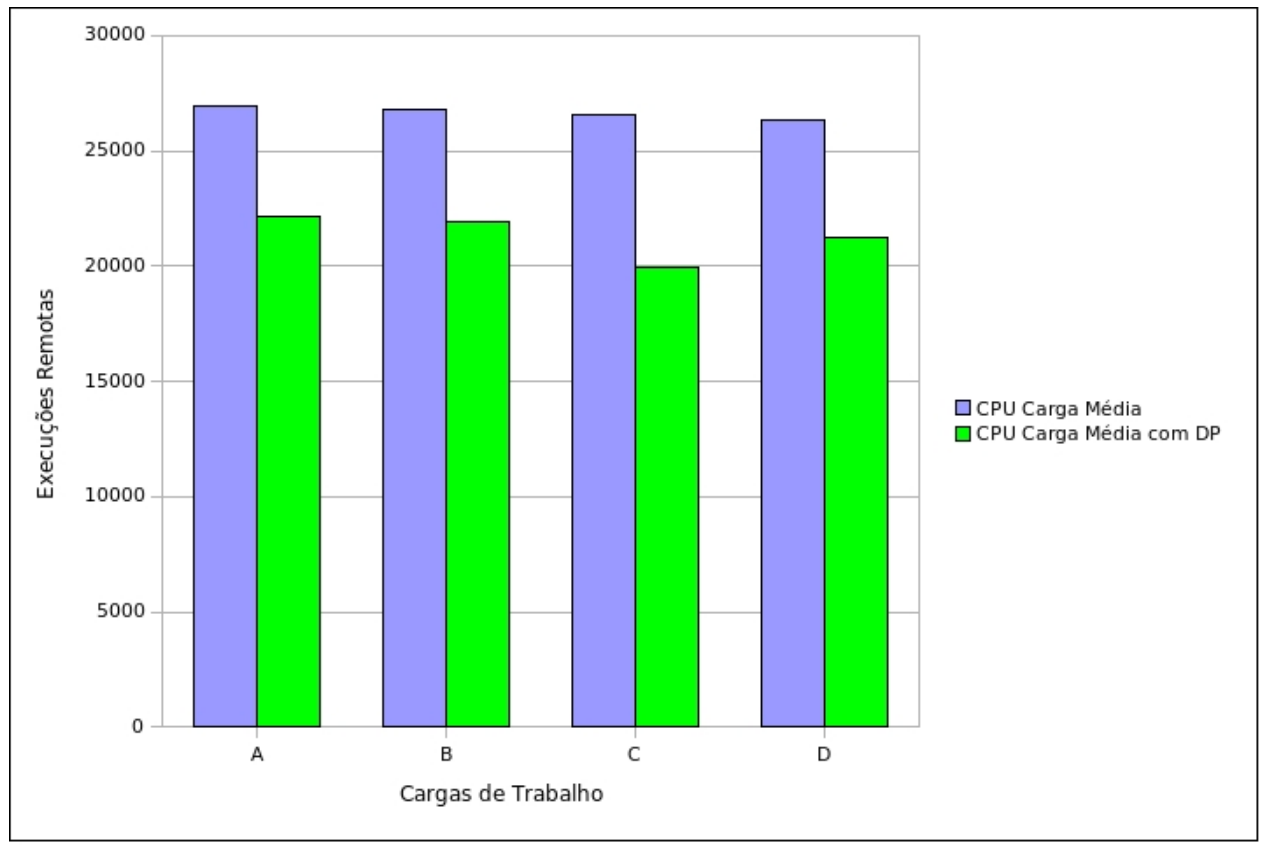

Figura 6.32: Execuções remotas realizadas pelas políticas baseadas unicamente em índices de CPU, ao serem executadas na "Plataforma 4".

Apesar das diferenças citadas com relação às execuções remotas realizadas, a redução na perda de desempenho para a carga "C" não foi ainda maior devido à quantidade de ausências de páginas, que foram 12,17\% menores ao se usar a política "CPU carga média com DP" para a carga "C" e 19,51\% para a carga "D".

Nessa plataforma, ao considerarem-se muitas execuções remotas, a política "CPU carga média" causa um desbalanço na memória, levando a ocorrências de ausências de páginas. Porém, devido à heterogeneidade de disco, muitos processos ficam aguardando por um tempo elevado na fila de swap, não sendo contabilizados na fila de prontos de um determinado nó, que é reconhecido pelos demais como descongestionado, recebendo mais processos.

Assim, para cargas que solicitam uma grande quantidade de recursos de memória, "C" e "D", a política "CPU carga média" tende a gerar mais ausências de páginas do que a política "CPU carga média com DP".

Ao compararem-se as políticas baseadas unicamente em índices de CPU com as demais, observa-se que as políticas que utilizam índices de memória apresentam melhores resultados. Assim, a figura 6.33 apresenta o gráfico de comparação entre as perdas de desempenho registradas pelas políticas que possuem índices de memória. 


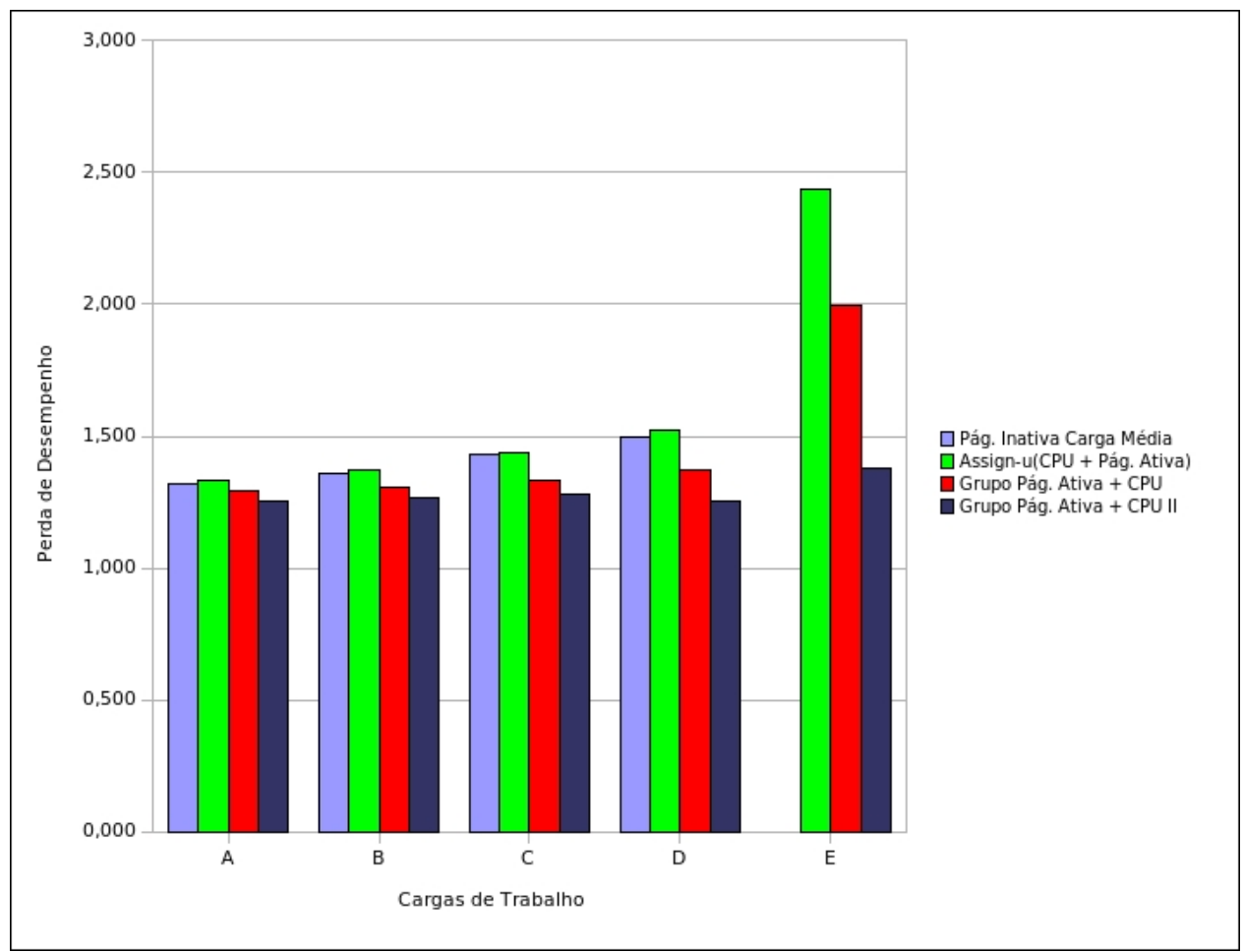

Figura 6.33: Perdas de desempenho registradas na "Plataforma 4", ao utilizar as políticas que utilizam índices de memória.

Ao analisar o gráfico citado, juntamente com a tabela 6.10, é possível notar que, para a carga "A" não existe diferença significativa entre as políticas "Pág. inativa carga média" e "Assign-u(CPU + Pág. ativa)". Para as cargas entre "B" e "D", não é possível afirmar, dentre essas duas políticas, qual a melhor política, já que as médias obtidas estão contidas nos intervalos de confiança.

Para a carga "E", a política Assign-u foi capaz de executar 10\% das simulações, enquanto $90 \%$ delas foram finalizadas pelo fato do sistema ter entrado em estado de trashing. Porém, a política "Pág. inativa carga média" não foi capaz de finalizar nenhuma simulação, para essa mesma carga, sem permitir que o estado de trashing fosse atingido.

Ao analisar as políticas baseadas em grupo, percebe-se que ambas são superiores às políticas "Pág. inativa carga média" e "Assign-u(CPU + Pág. ativa)". Ao comparar a política "Grupo pág. ativa + CPU" com a política de referência, baseada em memória, observa-se reduções de $8,47 \%$ para a carga "D" e $2,27 \%$ para a carga "A", sendo esses o maior e o menor valor obtido, respectivamente.

Ao comparar a política "Grupo pág. ativa + CPU II", com a política "Pág. inativa carga média", houve um redução na perda de desempenho variando entre 5,07\% e 16,34\% para as cargas "A" e "D", respectivamente.

As políticas baseadas em grupo foram as únicas a executarem de maneira satisfatória a carga de trabalho "E", sendo que a política "Grupo pág. ativa + CPU II" apresentou 
ser mais eficiente, registrando apenas 1,376 como perda de desempenho média, enquanto a política "Grupo pág. ativa + CPU" apresentou 1,994; portanto, uma diferença de aproximadamente $31 \%$.

Para essa mesma carga, a política "Grupo pág. ativa + CPU II" conseguiu finalizar 85\% das simulações sem permitir que o sistema entrasse em estado de trashing, enquanto a política "Grupo pág. ativa + CPU" conseguiu obter o mesmo comportamento com apenas $46,67 \%$ das simulações.

A superioridade registrada pelas políticas baseadas em grupo é proveniente da quantidade de ausências de páginas sofridas pelos processos. Na figura 6.34, verifica-se que a partir da carga "C", as ausências de páginas registradas nas políticas baseadas em grupo começam a se destacar, chegando a ser 69,90\% menor ao comparar os resultados obtidos com a política "Grupo pág. ativa + CPU" e a política "Pág. inativa carga média". Ao analisar a segunda política baseada em grupo, essa diferença aumenta para 94,53\%, utilizando a mesma política de referência.

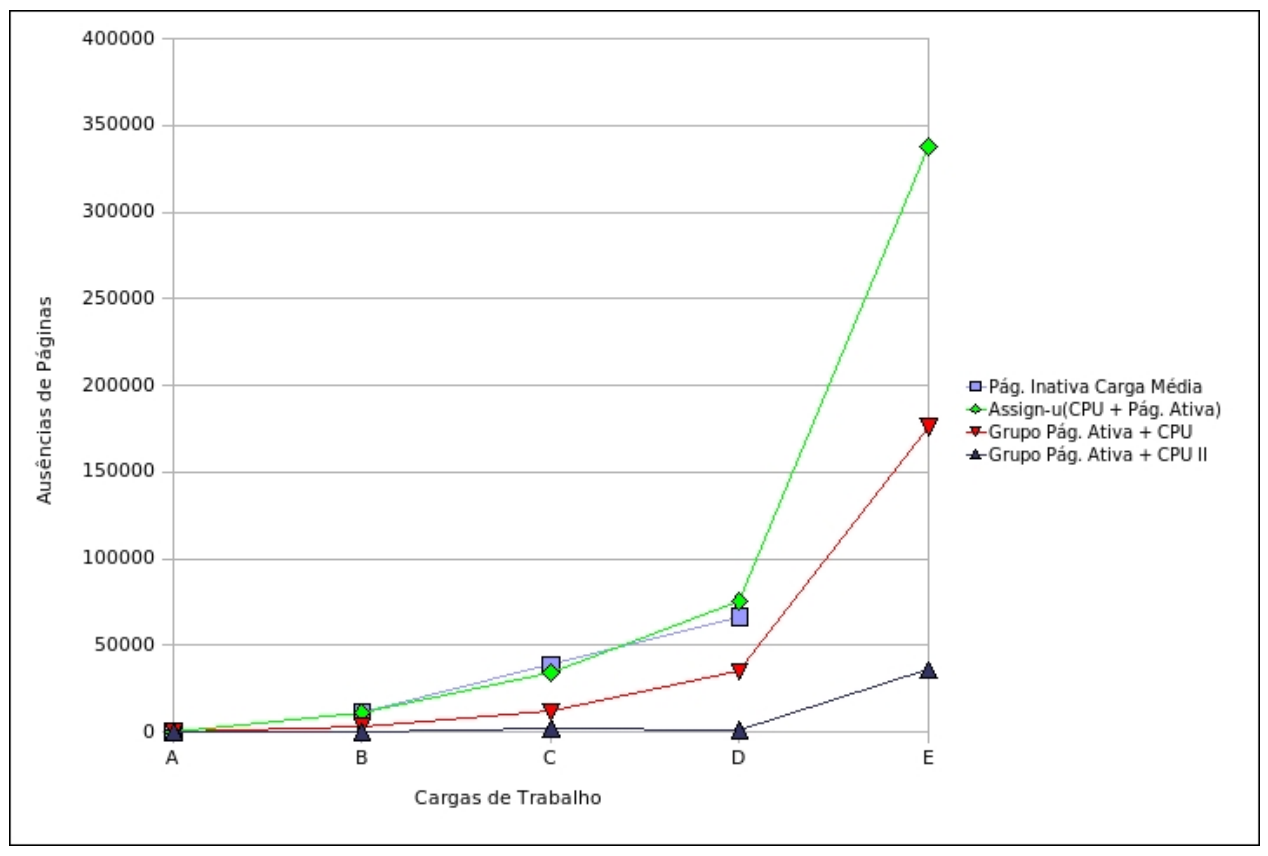

Figura 6.34: Ausências de páginas, ocorridas na "Plataforma 4", ao utilizar as políticas baseadas em índices de memória.

Essa diferença aumenta para 98,20\% ao analisar os resultados da política "Grupo pág. ativa + CPU II" e da política "Pág. ativa carga média" com a carga de trabalho "D". Esse comportamento é muito importante em plataformas com heterogeneidade de disco, pois, computadores com discos lentos, podem comprometer o sistema se forem submetidos a uma grande quantidade de ausências de páginas em um pequeno intervalo de tempo.

A vantagem apresentada pelas políticas em grupo, deve-se à tomada de descisão em duas etapas, sendo que na primeira, ao se selecionar as máquinas com quantidades de 
páginas ativas menores que a média do sistema, aquelas máquinas que estão sofrendo ausências de páginas são poupadas, uma vez que a quantidade de páginas ativas nessas máquinas é muito grande.

A segunda etapa de atribuir o processo para o nó com menor fila de prontos, retarda o acontecimento de ausências de páginas, pois o processo está sendo enviado para uma máquina com poucos processos e também com páginas inativas para atender a demanda solicitada.

Conforme mencionado na descrição das plataformas, a comparação entre os resultados obtidos na "Plataforma 4" seriam confrontados com aqueles gerados por uma plataforma homogênea, mas, diferente da "Plataforma 1", pois o tempo de tratamento de uma ausência de páginas deverá ser de $20 \mathrm{~ms}$ e não 10ms como utilizado na "Plataforma 1".

Essa comparação foi realizada e os resultados das perdas de desempenho sofridas pelos processos podem ser visualizados na figura 6.35.

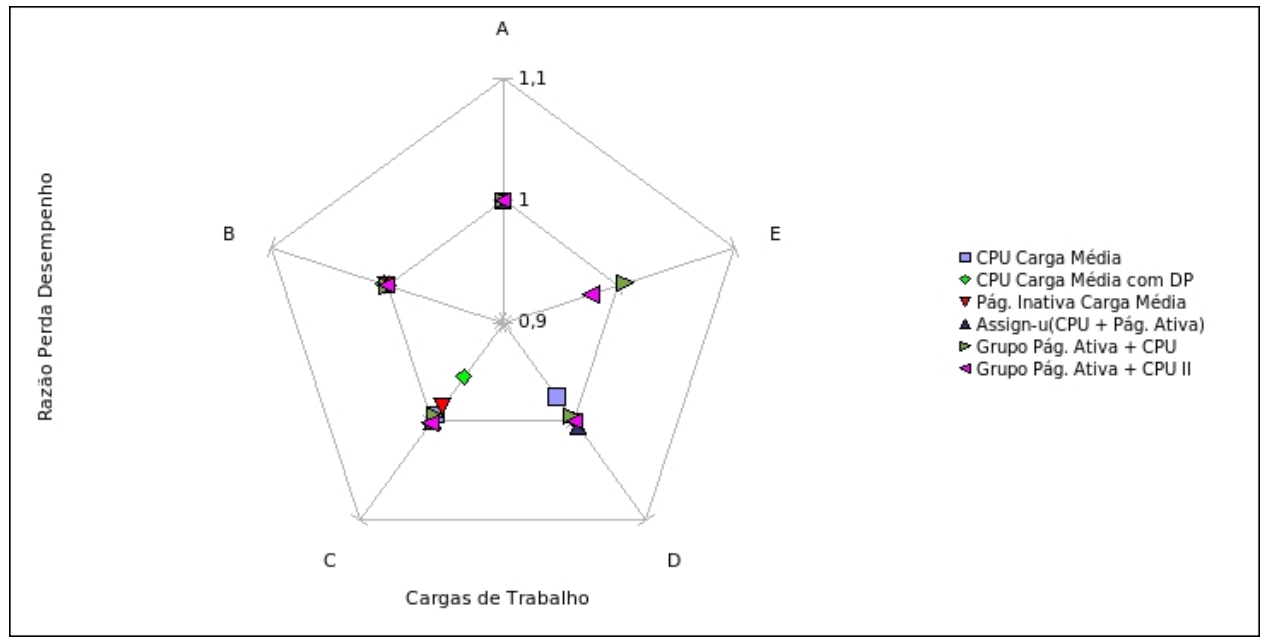

Figura 6.35: Razão entre as perdas de desempenho geradas na "Plataforma 4" e aquelas com a plataforma homogênea utilizando $F P=20 \mathrm{~ms}$.

Esse gráfico é formado pela razão entre as perdas de desempenho registradas com as políticas analisadas utilizando as cargas de trabalho entre "A" e "E" na "Plataforma 4", e as mesmas informações na plataforma homogênea. Entretanto, utilizando como tempo de tratamento de uma ausência de páginas, $F P$, o tempo de 20 ms.

Ao analisar o gráfico da figura 6.35, percebe-se que a variação entre os resultados foi pequena, uma vez que a razão próxima de um indica que os resultados obtidos para ambas as plataformas foram semelhantes. A maior variação obtida foi de $5 \%$ para a carga de trabalho "C" com a política "CPU carga média com DP", mostrando que a plataforma com heterogeneidade de disco chega a ser $5 \%$ superior, se comparada a uma plataforma que não apresenta heterogeneidade de disco. 
Ao analisarem-se todos os resultados tem-se que, apesar das pequenas variações nos resultados, utilizar discos com velocidades de acessos diferentes tende a aumentar o desempenho. Assim, pode-se entender que utilizar alguns discos com tempos de acesso menor, pode ajudar a melhorar o desempenho em um sistema de cluster com sistema de imagem única.

\subsection{Considerações finais}

Neste capítulo foram propostas três novas políticas de escalonamento que utilizam índices de CPU e de memória. A primeira política proposta é baseada no algoritmo Assign-u e as outras duas são baseadas no conceito de grupo, desenvolvido neste trabalho.

Para a política "Assign-u(CPU + Pág. ativa)" os pesos utilizados para o tamanho da fila de prontos e para a quantidade de páginas ativas são os mesmos, cujos valores são homogeneizados através da equação 6.3. As políticas baseadas em grupo, ao contrário, não utilizam o mesmo peso para índices de CPU e memória, realizando a seleção da máquina de destino em etapas.

Na primeira etapa, um conjunto de máquinas é pré-selecionado, baseando-se no índice de memória, e na segunda, apenas uma máquina é escolhida utilizando-se o índice de CPU. Essa divisão em etapas apresenta peso maior para o índice de memória, uma vez que esse índice pode eliminar máquinas candidatas, enquanto o índice de CPU possui caráter apenas classificatório.

Foi proposta ainda uma modificação da política "CPU carga média", em que o desvio padrão é utilizado para reduzir a quantidade de execuções remotas. Apesar de já existir na literatura algumas propostas desse tipo, todas elas utilizam índices de valor fixo, apresentando dificuldades para a definição do valor desse índice. A utilização do desvio padrão, ao contrário, não é um valor fixo e adapta-se à carga da plataforma.

A política "CPU carga média com DP" apresentou vantagens em relação à política de referência baseada em CPU, enquanto as demais políticas propostas apresentaram vantagens quando comparadas às políticas de referência, utilizando tanto índices de CPU quanto de memória.

Os resultados obtidos ratificam a afirmação feita em [6], de que as políticas que utilizam índices de memória e CPU são mais eficientes que aquelas que utilizam índices simples.

No entanto, em [6] as políticas propostas foram desenvolvidas em um cenário em que as quantidades de recursos necessários para as aplicações são conhecidos na submissão e são utilizadas aplicações $C P U$-bound. As políticas desenvolvidas nesta dissertação, ao con- 
trário, não possuem informações sobre os recursos necessários para as tarefas, tornando-as mais flexíveis.

Todas as políticas foram avaliadas mediante cargas de trabalho, definidas como "A", "B",..., "E", sendo executadas em diferentes plataformas. Ao definir as cargas propostas, caracterizaram-se cenários com presença dominante de aplicações $C P U$-bound e com poucas aplicações memory-intensive e cenários com presença de aplicações memory-intensive, com elevadas taxas de solicitação de memória.

Com relação às plataformas, foram caracterizados plataformas homogêneas e heterogêneas. A heterogeneidade abordada foi a configuracional, onde apenas quantidades de recursos apresentam diferenças. Ao total foram definidas quatro plataformas. A primeira, denominada "Plataforma 1", foi definida como homogênea e as demais possuem heterogeneidades nas capacidades de processamento, nas quantidades de memórias e nos tempos de acesso ao disco.

Durante a definição das plataformas heterogêneas tentou-se manter as quantidades de recursos presentes na plataforma homogênea, porém, para a "Plataforma 3", que apresenta heterogeneidade de memória, isto não foi possível, uma vez que todas as políticas levavam o sistema para o estado de trashing precocemente, indicando que a heterogeneidade de memória é a mais crítica dentre as estudadas.

Nos resultados obtidos apenas a heterogeneidade de tempo de acesso ao disco é benéfica, apresentando ganhos ao ser comparada a uma plataforma homogênea com o mesmo tempo médio de acesso ao disco. 


\section{Capítulo 7 \\ Conclusões}

Neste capítulo são apresentadas as principais ponderações e conclusões sobre o trabalho desenvolvido nesta dissertação de mestrado, incluindo sugestões para trabalhos futuros, visando à continuidade da pesquisa.

\subsection{Considerações finais}

Esta dissertação apresentou novas políticas de escalonamento para sistemas de imagem única em clusters, focando as aplicações memory-intensive.

Para o desenvolvimento deste trabalho foram analisados e utilizados os índices proposto em [5] e discutidos no capítulo 4. Dentre os índices propostos foram utilizados o tamanho da fila de prontos da CPU, a quantidade de páginas ativas e a quantidade de páginas inativas. O primeiro índice pode ser obtido no arquivo stat no campo procs_running e os demais no arquivo meminfo nas entradas Active e Inactive, respectivamente.

Esses arquivos encontram-se no pseudo-sistema de arquivos /proc, indicando que as informações coletadas pela política de informação podem ser obtidas no nível de usuário.

O índice páginas ativas representa a quantidade de memória realmente ocupada, já a quantidade de páginas inativas representa a quantidade de memória disponível para alocação. Os demais índices não apresentaram resultados satisfatórios ao serem utilizados nas políticas de escalonamento.

Os índices que indicam utilização do espaço de swap e da quantidade de ausências de páginas ocorridas, ao contrário do esperado no início deste projeto, não apresentaram 
bons resultados, uma vez que só refletem a utilização da memória virtual, ou seja, quando ausências de páginas começam a ocorrer e o espaço de swap começa a ser utilizado. Essa informação tardia não ajuda a recuperar o sistema do estado de trashing com eficiência, pois, na presença de aplicações memory-intensive as ausências de páginas devem ser evitadas ou retardadas ao máximo, pois, a partir do momento em que as ausências de páginas começam a ocorrer, o sistema já deve estar balanceado, caso contrário, a obtenção do estado de trashing será inevitável.

Para avaliar as políticas propostas foram utilizadas simulações baseadas em traces, utilizando o trace disponibilizado em [34] e [6] e utilizado em [33]. Nesse trace as quantidades de memória, solicitadas por cada processo, foram geradas através de uma distribuição de Pareto, utilizando o algoritmo disponível em [39], em conjunto com a função de geração de números pseudo-aleatórios disponível em [40].

Dentre as políticas apresentadas encontra-se a "CPU carga média com DP", que é uma modificação proposta na política "CPU carga média". Esta realiza muitas execuções remotas, pois faz o balanceamento pela carga média do sistema. Assim, a quantidade excessiva de execuções remotas leva essa política a perdas de desempenho desnecessárias. Assim, foi proposta neste trabalho a utilização do desvio padrão como fator de correção para a carga média do sistema. Dessa forma, uma máquina realizará uma execução remota apenas se sua carga for maior que a média do sistema acrescida do desvio padrão, como descrito no algoritmo 6.4

Essa estratégia mostrou-se muito eficiente, levando à redução nas perdas de desempenho em todas as plataformas e em praticamente todas as cargas de trabalho, devendo ter preferência nas implementações de clusters. A vantagem dessa abordagem é que a modificação a ser feita é muito simples, uma vez que as políticas baseadas em CPU são largamente utilizadas [8] e [33].

Com relação às demais políticas, foram apresentadas três novas propostas que utilizam tanto índices de memória quanto de CPU. A primeira política, denominada "Assignu(CPU + Pág. ativa), utiliza o algortimo Assign-u para homogeneizar os índices, ao contrário das demais que utilizam o conceito de grupo, onde a decisão é feita em duas etapas.

A política baseada no algoritmo Assign-u não apresentou reduções nas perdas de desempenho na plataforma homogênea ao ser comparada com a política "Pág. inativa carga média", no entanto, ela conseguiu executar 100\% das simulações para a carga "E", mostrando a sua estabilidade frente à política de referência, atualmente utilizada em produtos como o openMosix.

Essa estabilidade pode ser percebida também na "Plataforma 3", em que a política "Assign-u(CPU + Pág. ativa)" foi a única a executar $100 \%$ das simulações. Assim, 
pode-se dizer que essa política apresenta vantagens sobre a política tradicional baseada em memória, apresentando fácil implementação e um algoritmo competitivo. Sua principal vantagem está em plataformas com heterogeneidades de memória, cujas aplicações necessitam de grandes quantidades de memória.

As outras duas políticas baseadas em grupo foram unânimes em todas as plataformas, sendo que, a política "Grupo. pág ativa + CPU" é mais fácil de ser implementada que sua evolução "Grupo pág. ativa + CPU II". Porém, para ambientes onde o tempo de execução é muito importante, a última política citada deve ser adotada, pois, apesar de possuir implementação mais complexa que as demais, ela apresentou perdas de desempenho muito menores que a política base e aquela baseada no algoritmo Assign-u, chegando a uma diferença de 85,34\% na presença de carga "A" na "Plataforma 3", quando comparada à política base.

Assim, é possível concluir que as políticas propostas, tanto a que utiliza índices unicamente de CPU e aquelas que utilizam índices de CPU e memória, são superiores às políticas de referência, sendo que as políticas "CPU carga média com DP" e a "Assingu(CPU + Pág. ativa) são as mais fáceis de serem implementadas. Porém, as políticas baseadas em grupo apresentam reduções elevadas nas perdas de desempenho, ao custo de implementações mais complexas e sofisticadas.

\subsection{Contribuições}

No decorrer deste trabalho algumas contribuições foram realizadas, destacando-se:

- Levantamento bibliográfico envolvendo os trabalhos científicos publicados na área de escalonamento, bem como a análise crítica destes destacando as plataformas distribuídas, descrevendo e classificando os clusters de computadores, bem como a parte de software envolvida na consolidação de um sistema paralelo/distribuído, com destaque aos sistemas de imagem única. Isso permite que pesquisadores iniciantes tenham uma boa referência introdutória na área de escalonamento de processos em cluster de computadores, principalmente aqueles que utilizam sistemas de imagem única.

- Apresentação e análise crítica dos índices propostos por [5], apresentando os pontos fortes e fracos de cada um, bem como suas vantagens ao serem aplicados nas políticas de escalonamento. Isso poderá evitar que novas pesquisas sejam realizadas com índices já análisados e que não apresentam resultados satisfatórios;

- Desenvolvimento de um novo simulador de sistemas de clusters podendo simular sistemas de escalonamento tanto centralizados como descentralizados, utilizando 
execuções remotas e/ou migrações de processos. Esse simulador visa a preencher uma lacuna na literatura, uma vez que os simuladores encontrados apresentavam opções de configuração reduzidas com ausência de características presentes no sistema operacional GNU/Linux;

- Adaptação de uma política de escalonamento baseada em índices de CPU e desenvolvimento de três novas políticas baseadas em índices de memória e CPU, todas para sistemas de imagem única com a presença de aplicações memory-intensive;

- Análise do comportamento das políticas propostas e das políticas de referência, mediante cargas de trabalho com aplicações variando entre $C P U$-bound e memoryintensive e, ainda, em quatro plataformas onde a presença de diferentes heterogeneidades foram consideradas. Isso permite que administradores de sistemas empreguem as políticas que apresentarão os melhores resultados no ambiente à ser administrado, evitando a ampliação do parque de máquinas e/ou da quantidade de recursos da plataforma.

\subsection{Sugestões para trabalhos futuros}

A área em qual este trabalho está inserido é muito vasta e, assim, trabalhos futuros são essenciais para o avanço da pesquisa. Dentre os mais importantes destacam-se:

- Comparar as políticas propostas neste trabalho com aquelas que utilizam informações dos processos no momento do escalonamento. Informações como a quantidade de memória necessária e o tempo médio de utilização do processador;

- Comparar as políticas propostas com aquelas que utilizam migração de processos;

- Desenvolver novas políticas de escalonamento utilizando execução remota em conjunto com migração de processos, pois, ao utilizar-se apenas execução remota um desbalanceamento pode ser causado, através do efeito em "rajada" descrito no capítulo 6. Esse desbalanceamento pode ser corrigido mediante migração de processos;

- Aplicar as políticas desenvolvidas nesta dissertação em sistemas de escalonamento centralizado, comparando os resultados com aqueles obtidos com a política Roundrobin, bem como desenvolver novas políticas para este tipo de sistema.

- Modificar o código de um produto, como por exemplo o openMosix ou OpenSSI, para avaliar as políticas em um ambiente real, confirmando os resultados obtidos através de simulações e apresentando as oscilações dos resultados frente a um sistema real, visto que, durante a modelagem algumas características menos significantes foram omitidas. 
- Analisar o comportamento das políticas propostas frente a heterogeneidades multiplas, considerando:

- Capacidade de processamento e quantidade de memória;

- Capacidade de processamento e tempo de acesso ao disco;

- Quantidade de memória e tempo de acesso ao disco;

- Capacidade de processamento, quantidade de memória e tempo de acesso ao disco.

- Analisar o impacto da rede de sincronização utilizada neste trabalho, uma vez que a ausência da rede de sincronização aumenta o tempo de sincronismo entre as políticas de informação das máquinas, influenciando também no tempo de envio de processos para execução remota, já que a rede de acesso receberá também o tráfego de sincronização, aumentando a quantidade de pacotes trocados. Isso influencia no atraso dos pacotes, fazendo com que a política de informação utilize informações mais desatualizadas que as contidas neste trabalho.

- Desenvolver novas políticas de escalonamento, utilizando índices de entrada/saída, bem como de redes, uma vez que aplicações I/O-bound e network-intensive são comumente econtradas em sistemas de clusters, pricipalmente na presença de aplicações paralelas.

- Acrescentar ao simulador o escalonamento de aplicações paralelas, simulando as trocas de mensagens e sincronismos entre as partes de uma mesma aplicação. 


\section{Referências Bibliográficas}

1 DANTAS, M. Computação Distribuída de Alto Desempenho: Redes, Clusters e Grids Computacionais. Rio de Janeiro, RJ: Axcel Books do Brasil Editora Ltda, 2005. 278 p.

2 ANDERSON, T. E. et al. A case for now (networks of workstations). IEEE Micro, IEEE Computer Society Press, Los Alamitos, CA, USA, v. 15, n. 1, p. 54-64, 1995. ISSN 0272-1732.

3 FERSTL, F. Job-and resource-management systems in heterogeneous clusters. FGCS. Future generations computer systems, Elsevier Science, Amsterdam, PAYS-BAS, v. 12, n. 1, p. 39-51, 1996. ISSN 0167-739X.

4 TANEnBAUM, A. S. Sistemas Operacionais Modernos. 2. ed. São Paulo, SP: Pearson Education do Brasil, 2003. 695 p.

5 VOORSLUYS, W. Avaliação de Índices de Carga de Memória em Sistemas Computacionais Distribuídos. Dissertação (Mestrado) — ICMC, USP, São Carlos, SP, Março 2006.

6 XIAO, L.; CHEN, S.; ZHANG, X. Dynamic cluster resource allocations for jobs with known and unknown memory demands. IEEE Trans. Parallel Distrib. Syst., IEEE Press, Piscataway, NJ, USA, v. 13, n. 3, p. 223-240, 2002. ISSN 1045-9219.

7 FEITELSON, D. G.; RUDOLPH, L. Parallel job scheduling: Issues and approaches. In: IPPS '95: Proceedings of the Workshop on Job Scheduling Strategies for Parallel Processing. London, UK: Springer-Verlag, 1995. p. 1-18. ISBN 3-540-60153-8.

8 BRANCO, K. R. L. J. C. Índices de Carga e Desempenho em Ambientes Paralelos/Distribuídos - Modelagem e Métricas. Tese (Doutorado) — ICMC, USP, São Carlos, SP, Dezembro 2004.

9 ZHOU, S. et al. Utopia: a load sharing facility for large, heterogeneous distributed computer systems. Software - Practice and Experience, v. 23, n. 12, p. 1305-1336, 1993. 
10 BUYYA, R. High Performance Cluster Computing: Architectures and Systems. Upper Saddle River, NJ, USA: Prentice Hall PTR, 1999. ISBN 0130137847.

11 SANTANA, R. H. C. et al. Técnicas para Avaliação de Desempenho de Sistemas Computacionais. Monografia (Notas Didáticas) — ICMC, USP, São Carlos, SP, 1997.

12 BAR, M. The openMosix Project. 2006. Acessado em 04 de dezembro de 2006. Disponível em: <http://openmosix.sourceforge.net>.

13 OLESZKIEWICZ, J.; XIAO, L.; LIU, Y. Effectively utilizing global cluster memory for large data-intensive parallel programs. IEEE Trans. Parallel Distrib. Syst., IEEE Press, Piscataway, NJ, USA, v. 17, n. 1, p. 66-77, 2006. ISSN 1045-9219.

14 SOUZA, P. S. L. de. AMIGO: Uma Contribuição para a Convergência na Área de Escalonamento de Processos. Tese (Doutorado) — IFSC, USP, São Carlos, SP, junho 2000.

15 SHIRAZI, B.; HURSON, A. R. Special issue on scheduling and load balancing guest editors' introduction. J. Parallel Distrib. Comput., v. 16, n. 4, p. 271-275, 1992.

16 CASAVANT, T. L.; KUHL, J. G. A taxonomy of scheduling in general-purpose distributed computing systems. IEEE Trans. Softw. Eng., IEEE Press, Piscataway, NJ, USA, v. 14, n. 2, p. 141-154, 1988. ISSN 0098-5589.

17 SHIVARATRI, N. G.; KRUEGER, P.; SINGHAL, M. Load distributing for locally distributed systems. Computer, IEEE Computer Society Press, Los Alamitos, CA, USA, v. 25, n. 12, p. 33-44, 1992. ISSN 0018-9162.

18 RAPINE, C.; SCHERSON, I. D.; TRYSTRAM, D. On-line scheduling of parallelizable jobs. In: European Conference on Parallel Processing. [S.l.: s.n.], 1998. p. $322-327$.

19 AWERBUCH, B.; AZAR, Y.; FIAT, A. Packet routing via min-cost circuit routing. In: Israel Symposium on Theory of Computing Systems. [S.l.: s.n.], 1996. p. 37-42.

20 FEITELSON, D. G. et al. Theory and practice in parallel job scheduling. In: IPPS '97: Proceedings of the Job Scheduling Strategies for Parallel Processing. London, UK: Springer-Verlag, 1997. p. 1-34. ISBN 3-540-63574-2.

21 PERIS, V. G. J.; SQUILLANTE, M. S.; NAIK, V. K. Analysis of the impact of memory in distributed parallel processing systems. In: SIGMETRICS '94: Proceedings of the 1994 ACM SIGMETRICS conference on Measurement and modeling of computer systems. New York, NY, USA: ACM Press, 1994. p. 5-18. ISBN 0-89791-659-X. 
22 PAXSON, V. et al. Framework for ip performance metrics. RFC Editor, , United States, 1998.

23 FERRARI, D.; ZHOU, S. An empirical investigation of load indices for load balancing applications. In: Performance '87: Proceedings of the 12th IFIP WG 7.3 International Symposium on Computer Performance Modelling, Measurement and Evaluation. [S.1.]: North-Holland, 1988. p. 515-528. ISBN 0-444-70347-0.

24 TANEnBAUM, A. S. Distributed Operating Systems. 5. ed. New Jersey, USA: Prentice Hall International, 1995. 614 p.

25 MEHRA, P.; WAH, B. W. Automated learning of load-balancing strategies in multiprogrammed distributed systems. International Journal of Systems Science, v. 28, n. 11, p. 1077-1099, 1997.

26 SAPHIR, W.; TANNER, L. A.; TRAVERSAT, B. Job management requirements for nas parallel systems and clusters. In: IPPS '95: Proceedings of the Workshop on Job Scheduling Strategies for Parallel Processing. London, UK: Springer-Verlag, 1995. p. 319-336. ISBN 3-540-60153-8.

27 SENGER, L. J. Escalonamento de processos : Uma Abordagem Dinâmica e Incremental Para a Exploração de Características de Aplicações Paralelas. Tese (Doutorado) - ICMC, USP, São Carlos, SP, Dezembro 2004.

28 KUNZ, T. The influence of different workload descriptions on a heuristic load balancing scheme. IEEE Trans. Softw. Eng., IEEE Press, Piscataway, NJ, USA, v. 17, n. 7, p. 725-730, 1991. ISSN 0098-5589.

29 AMIR, Y. et al. An opportunity cost approach for job assignment in a scalable computing cluster. IEEE Trans. Parallel Distrib. Syst., IEEE Press, Piscataway, NJ, USA, v. 11, n. 7, p. 760-768, 2000. ISSN 1045-9219.

30 ACHARYA, A.; SETIA, S. Availability and utility of idle memory in workstation clusters. In: SIGMETRICS '99: Proceedings of the 1999 ACM SIGMETRICS international conference on Measurement and modeling of computer systems. New York, NY, USA: ACM Press, 1999. p. 35-46. ISBN 1-58113-083-X.

31 BARAK, A.; BRAVERMAN, A. Memory ushering in a scalable computing cluster. 1997.

32 YOUN, C. Performance improvement of cluster system by server status information. In: ICIS '05: Proceedings of the Fourth Annual ACIS International Conference on Computer and Information Science. Washington, DC, USA: IEEE Computer Society, 2005. p. 282-287. ISBN 0-7695-2296-3. 
33 WANG, Y.-M. Local cluster first load sharing policy for heterogeneous clusters. $J$. Inf. Sci. Eng., v. 23, n. 2, p. 497-510, 2007.

34 XIAO, L.; ZHANG, X.; QU, Y. Effective load sharing on heterogeneous networks of workstations. In: IPDPS '00: Proceedings of the 14th International Symposium on Parallel and Distributed Processing. Washington, DC, USA: IEEE Computer Society, 2000. p. 431. ISBN 0-7695-0574-0.

35 STAllingS, W. Arquitetura e Organização de Computadores. São Paulo, SP: Makron Books, 2002. 792 p.

36 MACDOUGALL, M. H. Simulating computer systems: techniques and tools. Cambridge, MA, USA: MIT Press, 1987. ISBN 0-262-13229-X.

37 HARCHOL-BALTER, M.; DOWNEY, A. B. Exploiting process lifetime distributions for dynamic load balancing. ACM Trans. Comput. Syst., ACM, New York, NY, USA, v. 15, n. 3, p. 253-285, 1997. ISSN 0734-2071.

38 FEITELSON, D. G. Parallel Workloads Archive. 2008. Acessado em maio de 2008. Disponível em: <http://www.cs.huji.ac.il/labs/parallel/workload/>.

39 CROVElla, M.; HARCHOL-BALTER, M.; MURTA, C. Task Assignment in a Distributed System: Improving Performance by Unbalancing Load. Boston, MA, USA, 1997.

40 JAIN, R. K. The Art of Computer Systems Performance Analysis. 1. ed. San Francisco, CA, USA: Wiley, 1991. 720 p. 